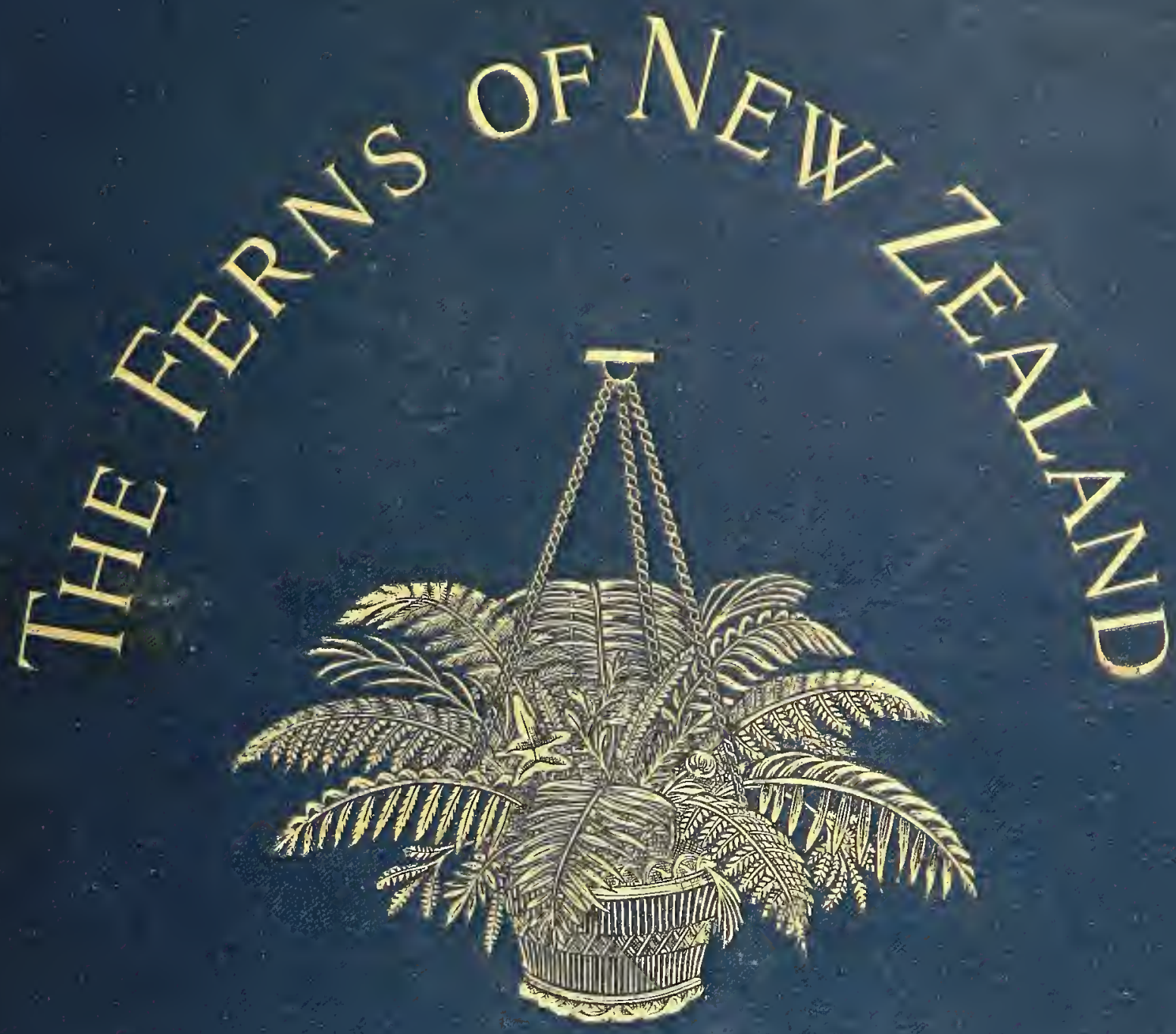




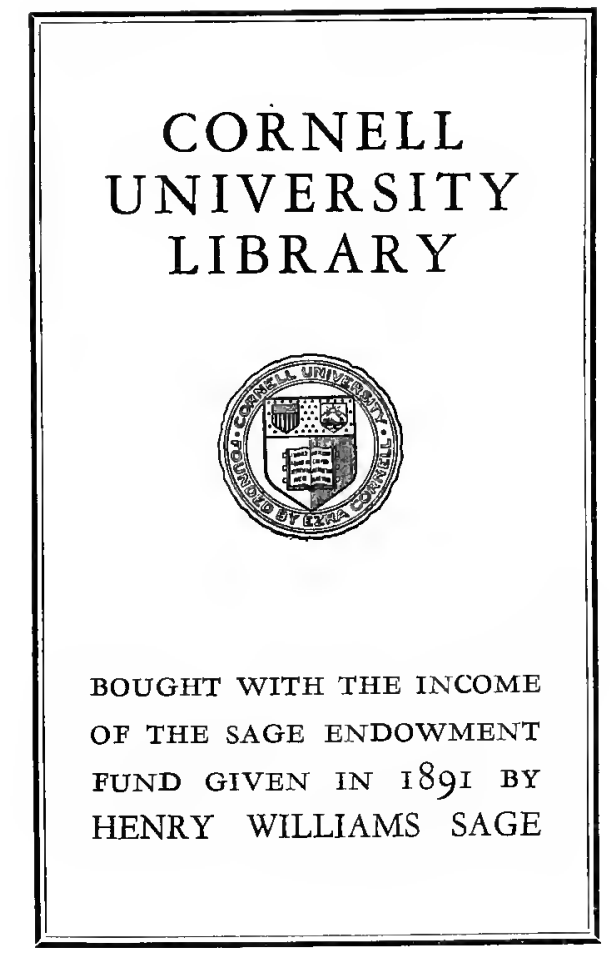

\section{RETURN TO \\ ALBERT R. MANN LIBRARY}

ITHACA, N. Y. 


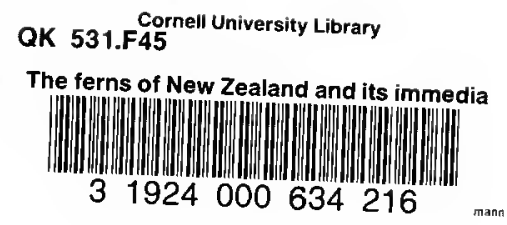




\section{Cornell University Library}

\section{The original of this book is in the Cornell University Library.}

There are no known copyright restrictions in the United States on the use of the text. 
THE FERNS OF NEW ZEALAND. 


\title{
FERNS OF NEW ZEALAND
}

\author{
AND ITS IMMEDIATE DEPENDENCIES,
}

WITH

D I R E C T I O N S

FOR

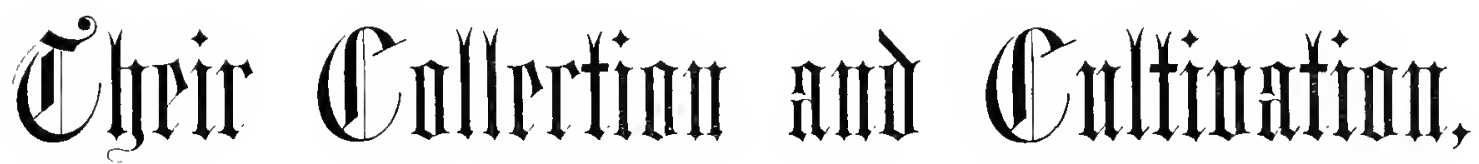

H. C. Field, C.E., Member of New Zealand Institite.

GRIFFITH, FARREN, OKEDEN, AND WELSH,

NEWBERY HOUSE, CHARING CROSS ROAD, LONDON; AND SYDNEY, N.S.W.

NEW ZEALAND :

A. D. Willis, wanganUi.

MDCç. 


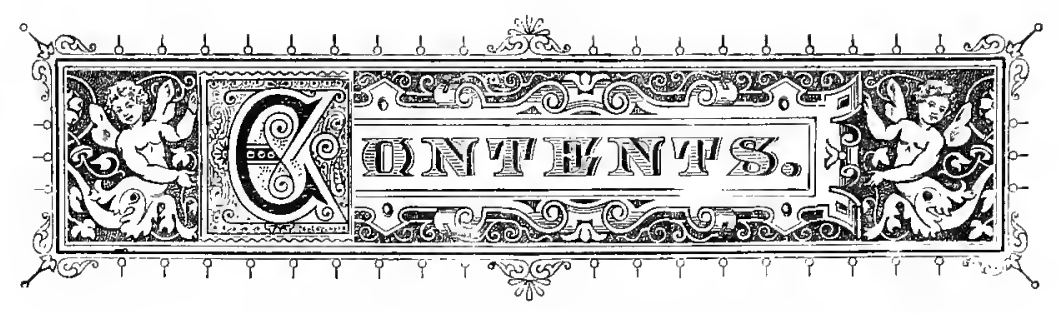

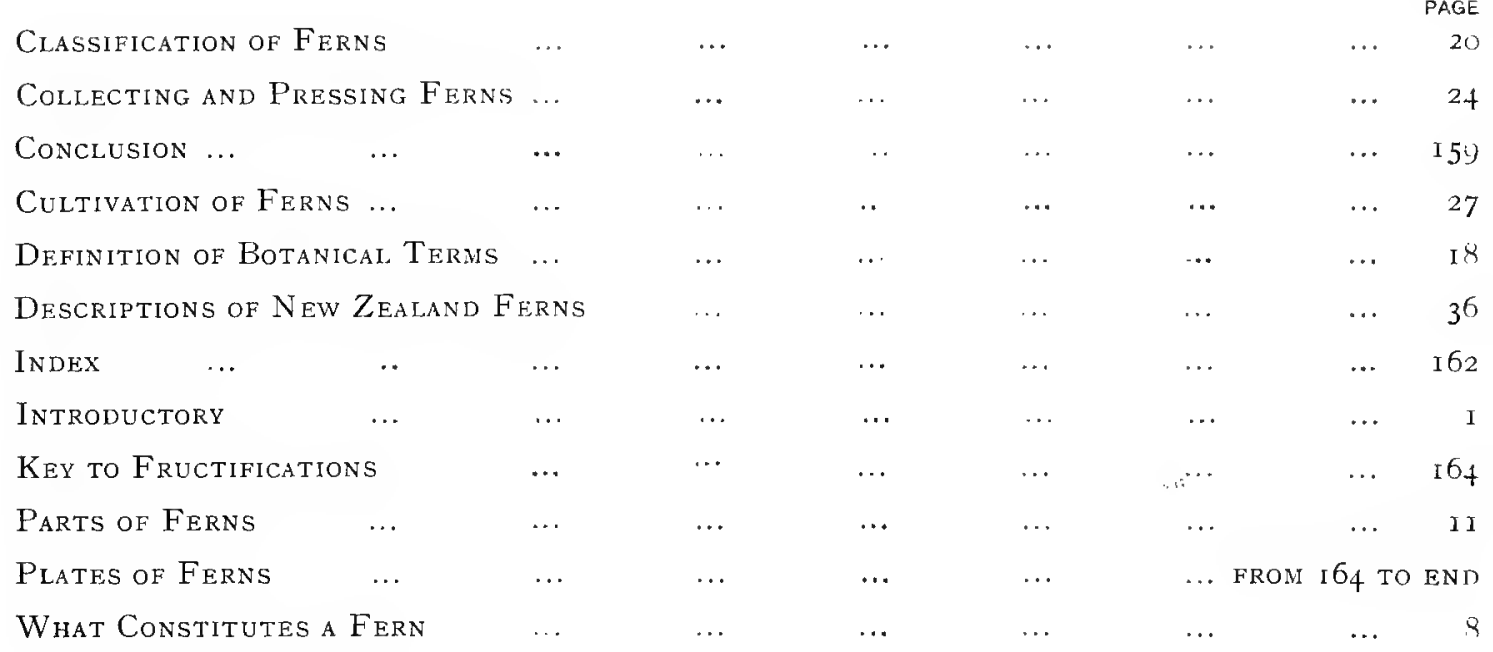




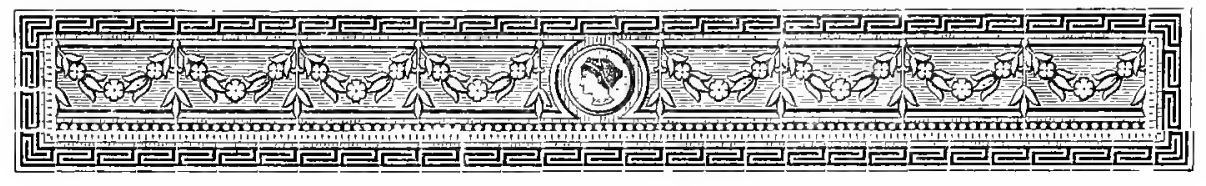

\section{INTRODUCTORY.}

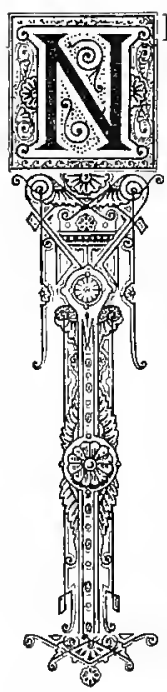

EW ZEALAND has been called "The Land of Ferns," and this not without reason, as there are probably a greater number and variety of these plants within its limits than are to be found in any other country of equal area. This no doubt arises from its being situated in the latitude of the westerly winds of the southern hemisphere, which reach its shores charged with the moisture that they have imbibed as trade-winds in the tropics, and which they discharge on arriving at the mountain ranges of the Colony: thus giving it a humid climate, highly favourable to vegetation. The great length of the colony (nearly goo miles) in proportion to its width, and the height of its mountains, give it a very wide range of temperature from a semi-tropical climate at the sea level, near the North Cape, to the perpetual snow of the Southern Alps. From this cause the Colony contains plants of classes varying from tropical to arctic to a very unusual extent. Much of its vegetation, too, and particularly its palms and tree ferns, indicate that New Zealand had formerly a warmer temperature than at present, and a tropical flora, of which these are a lingering remnant, which has gradually become acclimatised. To anyone interested in botany, it seems very wonderful to find such plants growing within a short distance of edelweiss and gentians allied to those of the European Alps, and of other forms whose natural habitat should apparently be Norway and Sweden, or even farther north. The great range of the geological formations of the Colony, too, by producing an immense variety of soils, is also highly conducive to a variety of regetation, the extensive volcanic formations, in particular, giving rise to a class of earths strange to most Europeans, and a corresponding flora. 
Most colonists have greater or less acquaintance with our New Zealand ferns, and very many cultivate some, or try to do so, for the sake of their bright fresh green colours, but comparatively few have, or apparently care to have, a really intelligent knowledge of them, because they cannot classify them, and are frightened by the botanical names assigned to them, and the Latin or Latinised Greek terms in which the descriptions are given in scientific text-books. I have often heard persons say, "Why not give English names to plants?" The answer is easy. If Englishmen want English names, the inhabitants of all other countries will want names in their own languages too; aind who could identify a plant called by a score or more names in different places, and know that it was the same one in all cases? This difficulty is at once avoided by giving the plant a scientific name (usually more or less descriptive) in a tongue which is not now spoken in any country, and yet is understood by educated people of all races. As it is, the ferns have local names in Europe, for instance, "Lady Fern," "Male Fern," "Royal Fern," "Shieid Fern," "Oak Fern," "Parsley Fern," "Bracken," \&c., in England, and the same plants are known by other names on the Continent; but what Englishman knows the German or Russian names, and what German or Russ knows the English ones? Many New Zealand ferns have Maori names, but how few even of colonists know them, and what a muddle a large proportion of those few make of pronouncing them! English names have, however, been given to some by settlers. The object of the following pages is to supply, in popular form, intelligible to the ordinary run of readers, such information respecting the New Zealand ferns as may enable them to be readily identified and classified, and thus add much to the interest taken in them by their admirers. I feel sure that almost everyone who gathers a fern, merely on account of its attractive form or colour, would like to know what it is, and that such knowledge would increase the number of fern gatherers, by all those who at present neglect the plants merely because they cannot name them, and are unwilling to look foolish through not being able to do so.

Descriptions of the colonial ferns, often illustrated by drawings, occur in the writings of the naturalists who accompanied the early exploring expeditions that visited New Zealand, and the whole of these, up to 1853 , were embodied in Dr. Hooker's "Flora Novœ Zelandiæ," published under the authority of the Colonial Government. Even this, however, is now out of print; and the straitened state of the colonial finances has, thus far, prevented the issue of a second edition revised and completed to the present time. The high price of the book limited its sale, and the scientific terms in which the descriptions are given precluded its becoming popular, highly valuable as it is as a work of reference. It contains some errors, such as classing separately what are only widely-differing forms of the same plant; and failing, in other cases, to discriminate between plants which nearly resemble each other in appearence, 
yet whose different habits of growth show them to be quite distinct. Such errors, however, were unavoidable in a work prepared mostly from dried specimens and written descriptions; and the wonder is that they were so few in number. Further descriptions, by New Zealand botanists, are scattered through the pages of the "Transactions of the New Zealand Institute" for the last twenty years; but these and the other works above-mentioned are inaccessible to the great majority of readers; and as it has been well said that "no scientific subject will ever be popular until it is popularly taught," the want of a popular description of New Zealand ferns was early felt. Sereral attempts have been made to supply this want, but thus far with limited success. The first was in the form of a "Handbook to the Ferns of New Zealand," published in Auckland in 1861 , and attributed to the wife of Commissary-General Jones. It was sold in aid of a church building-fund, and has been long out of print. As it was stated to be chiely compiled from "Dr. Hooker's Flora N.Z." and his son's "Species filicum," the mistakes in those works were copied; and, of course, it does not mention the ferns which have been discovered since its date. It contained, too, no glossary of the scientific terms used in it: but still, as a first attempt to popularise the study of the N.Z. ferns, it was most creditable; and those who possess copies seem generally to prefer it to the more finished and complete hand-book, "Ferns which grow in New Zealand and the adjacent islands, plainly described by H. E. S.L.", published in Auckland in I 875. This was also the work of a lady; but though written in a popular style, it has not, I believe, reached a second edition. It contains a glossary of scientific terms, but its author tried to avoid using them in her description, and employed instead words which were meant to be synonymous, but which are ar more puzzling than the scientific terms would have been, even to non-scientific readers. The extreme completeness of the descriptions is also bewildering. Instead of giving merely such main peculiarities as would enable a fern to be distinguished from others of its class, all sorts of petty details were noted; and as some of these rould often be wanting or different in specimens gathered by collectors, the absence or difference would make the identification of such specimens difficult or doubtful. The arranging of all the species of each genus alphabetically also makes identification far more diffcult; as one has to choose between a dozen or more plants, instead of only three or four; as would be the case by adhering to the scientific classification. Of course recent discoveries are wanting, and some of the old mistakes repeated and new ones made; yet the little book deserved to be far more successful and widely circulated than it appears to have been. The last and best book on the subject is that on "The Ferns and Fern Allies of New Zealand," by G. M. Thomson, Esq., F.L.S., of Dunedin. Its published price, however, was higher than most people cared to pay for mere letterpress; and it was objected that the descriptions were too scientific for ordinary readers. The size and price of the book were, of course, slightly increased by the inclusion of 
the fern-allies; and as regards the second objection, it would be almost impossible to give intelligible descriptions in non-scientific language, without greatly increasing their length and complexity; as one immense advantage of a scientific nomenclature is its conciseness. I believe, however, that the main reason why this and the handbooks have not hit the popular taste has been that a written description of a plant can hardly render it capable of identification by a non-scientific reader, unless it is illustrated by a drawing. In fact, I believe most people would identify by a drawing alone far more readily than by any mere description. The plates given in $\mathrm{Mr}$. Thomson's book were only of portions of fronds, showing the fructification, and this seems to have been regarded as insufficient to enable identification of the plants. The price has now been lowered, and I learn that it is selling far better in consequence.

In this work, the descriptions will be all or nearly all illustrated; and thus it is hoped that the difficulty will be overcome. Till now, the only popular attempt that has been made to illustrate the ferns pictorially was by some impressions, apparently executed in splashwork, which were published several years ago, and were attributed to Miss Dobie, who was murdered by a Maori near Opunake, or to her brother. They were, however, so roughly got up that few people seemed to care to buy them : in fact, as the fructification of the ferns was not shown, it would have been almost impossible to identify some of them from the drawings. In our plates, which are drawn from actual specimens, I have given as nearly as possible the general appearance or form of each fern: for the same plant often varies greatly in different localities, and at different stages of growth. It may be noted here that, as a rule, young fronds are more brightly tinted than old ones, but the amount of light where a plant grows greatly affects its colour. A fern, which is usually of a dark green, will often assume a golden hue when the bush in which it grows is cleared, or partially so. The young fronds, too, of some ferns present lovely shades of rose, purple, and orange; the veins sometimes being of a different colour from the web of the frond. These colours die away as the frond attains its full development and hue, and they cannot be preserved by drying. They seem to depend on the soil, the young fronds of the same species differing in colour in different places. Limestone soils appear to produce the brightest colours. The limited size of the plates necessitated the use of small fronds from young plants, for the illustrations, even though many of the coarse-foliaged ones were reduced considerably in the drawings; and in this way it may happen that the description of a particular fern may represent it as more divided than the specimen drawn in the illustration; but still the latter will show the general character of the plant, so as to enable it to be identified.

Many fern collectors have been puzzled from time to time by the changes that have taken place in the names of N.Z. ferns, the same plant being differently called by different writers. This difficulty, however, is now disappearing, through the publi- 
cation, in 1874, of the "Synopsis filicum," commenced by the late Sir W. Hooker, and completed by his successor in the office of custodian of the Royal Herbarium at Kew, J. G. Baker, Esq., F. L. S. That work contains classified descriptions of all the then known ferns; but in the interval between its first and third editions several hundred new ferns reached the herbarium and had to be added as an appendix; and since then several hundred more have arrived; so that the total number of classified ferns must now exceed 4000, of which about 140 are known to occur in New Zealand and its immediate dependencies, and a few others have probably still to be discorered on its mountains or in other little-known localities. Several have been reported lately, and will be noted in this book, though possibly I may not be able to give drawings of them; but it is not yet certain whether they are all new, or merely new forms of known ferns; though from the descriptions some appear certainly new. There is great diversity in estimating the number of N.Z. ferns. This arises from the fact that nearly all of them vary greatly in different localities, and some persons regard these variations of form as constituting distinct species. Reckoning in this fashion, a list of probably over iooo ferns might be assigned to the colony; but there are such continuous links connecting them that there can be no doubt in the mind of anyone who has had good opportunities of seeing the plants and observing the links that the differences are merely variations of form. A gentleman at Christchurch, who has probably collected and grown more ferns than any one else in the colony, lately expressed the opinion that, if all the connecting links could be traced out, the $N$. Z. list would be reduced to about a dozen plants. Connecting links between ferns, which in one locality seem quite distinct, crop up in another perhaps hundreds of miles distant. It would seem, indeed, as if what are classed as species are often only well marked types: but they scrve for classification. The same thing occurs with English ferns, forms of which are branched, crested, and depauperated almost past recognition. I have in cultivation more than twenty perfectly distinct forms of the "Lady fern," and an Edinburgh florist advertises a list of eighty; yet no one who really understands ferns doubts their being really only varieties of the one plant. The tendency of scientific men in the present day is to narrow the number of plants as far as possible, with a view to simplifying their classification; and it is in this way that the names of some of the N. Z. ferns have been changed, because they belonged to sub-genera which, so far as name is concerned, are now merged in the main genera, though the sub-genera are still kept up as an assistance in classification. It is questionable whether, in one instance, a mistake has not been made: whether, in fact, the difference which constitutes the sub-genus is not sufficient to justify a separate main genus; but this, of course, is matter of opinion; and so long as the question does not prevent the identification of the plants, it is of little moment to us. Some of the N.Z. ferns had not reached Kew when the third edition of the Synopsis was published, or had not been 
recognised as distinct species, owing to the imperfection of the specimens or want of full information as to their habits of growth; and thus they will appear (if they have not by this time done so) in a second appendix. In preparing the Synopsis, the rule was laid down of assigning to each fern the name given to it by its first discoverer, or at all events by the first person from whom specimens were received at Kew. It was found that, in many cases, the same fern had been met with in different places by a number of persons, each of whom supposed that he was its first discoverer, and therefore gave it a name. Thus the plant was in the Herbarium under a variety of names; and to avoid any appearance of favouritism, the rule of taking the first name was adopted; though, in some cases, a different subsequent one would have been more descriptive of the plant. For instance, the old name "crispatum," applied to one of the N.Z. Hymenophylla is beautifully descriptive of the plant; while the adopted name "Javanicum" does not describe it at all, but merely intimates that it was first found in Java. It is quite possible, however, that the peculiar crisped appearance which distinguishes the N. Z. plant is less noticeable in the tropical form of it found in Java.

In the following pages, though the names and classification of the Synopsis will be generally adhered to, the other names by which any particular fern is known to have been called will be given as synomyms. Of course, the ferns not mentioned in the Synopsis will be called by the names assigned to them by their discoverers, or which have been given to them at Kew. Where two ferns have been confounded in that work, they will be separately described; and where two forms of one fern appear to have been separately classed, the fact will be noted. By these means it is hoped to make the book as complete and reliable as possible. The Synopsis will be my chief authority as regards the other countries in which the New Zealand ferns occur; and in some few cases I have relied on Mr. Thomson's mention of them as occurring in parts of the colony where I was not aware of their occurrence, either from my own knowledge or the information of friends, or the various papers in the Transactions of the New Zealand Institute. My own fern-hunting has extended from beyond Auckland on the North to the Otago goldfields on the South; and through the kindness of friends I have specimens, and even living plants, from localities as wide apart as the Three Kings and Stewart's Island. Four of my sons, too, are or have been on the Government Survey Staff, and both from them and other members of the staff, and my two other sons, who also take interest in ferns, I have received many plants and specimens from places that I have not myself visited. Few colonists, therefore, if any, have had better opportunities of becoming thoroughly acquainted with the New Zealand ferns in all their various forms. I have received, and gratefully acknowledge; very valuable information and assistance in the above ways from J. G. Baker, Esq., of Kew; the Ven. Archdeacon Stock, Professor Kirk, and Messrs. T. B. Kirk and H. F. 
Logan, of Wellington; the Rev. W. Colenso, of Napier; T. S. Cheeseman, Esq., of Auckland; Messrs. J. B. Armstrong, Abbott, Brown, Monro, and Adams, of Christchurch; G. Roberts, Esq., of Hokitika; Major Brown and Mr. Henry, of Taranaki; Messrs. G. M. Thomson, J. Buchanan, A. C. and A. Purdie, and G. Matthews, of Dunedin; and Messrs. A. Allison, Jos. Annabell, A. Warner, and A. Murray, of Wanganui; as well as from several ladies in various parts of the colony who might not care to see their names in print.

As my book is intended chiefly for unlearned readers, to the names of the ferns at the heads of the descriptions and elsewhere I have appended a guide to the pronunciation, to prevent such common mistakes as pronouncing Hymenophyllum ( $\mathrm{Hy}$ men-o-phyl-lum), which means "filmy leaf;" Hymenophilum (Hymen-oph-il-um), which would mean "film-loving," and be nonsense : or calling Gleichenia, in which the ei has the hard sound of $i$ in "file," the ch is a guttural, and the second e scarcely sounded, as if it were written Glikeenia or Gleekeenia.

I shall also give directions for pressing and preserving ferns; as well as hints respecting their cultivation, which may be found useful, as they are the result of many years experience in this way, and may save my horticultural readers from disappointment. I shall also mention the situations in which the several ferns are likely to be found, and localities in which they have been so already; but it must not be supposed that these are the only ones. I may say that scarcely any part of the colony has been thoroughly botanically examined, because its area is so large, and those who have both taste and leisure for the work are so few in number. N. Z. ferns, too, like our other plants, have a trick of cropping up in unexpected places. Gleichenia Cunninghamii, for instance, which is usually found in high ridges sooo feet or more above sea-level, occurs beside a small stream only just above high-water mark, near Auckland; and I found the Alpine Lomaria at Wanganui within 30 feet of the sealevel, and the Otago fern Asplenium Lyallii by Wellington Harbour. Only last year I came across a patch of Gleichenia circinata, where it must have been growing for probably a century, within a mile of my own house, though I had never before seen it nearer than Rotorua, I50 miles away, and must have passed within a few yards of it scores of times in the last 37 years. Thus collectors should always keep their eyes open as they never know what they may find.

H. C. FIELD. 


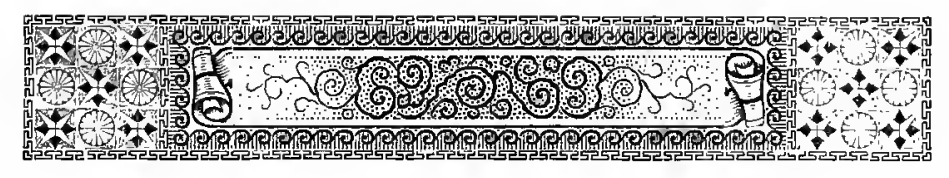

\section{WHAT CONSTITUTES A FERN.}

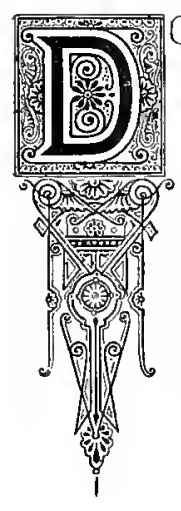

OUBTLESS most of my readers think they can at once distinguish ferns when they see them; and yet, if a number of such plants, intermixed with closely allied forms and fernlike branches, were placed before them, they would make all sorts of mistakes by classing the other things as ferns, and the true ferns as mosses or other growths. It is important, therefore, to define a fern. To begin with, a fern is a cryptogam. Most of my readers will have seen, this word, which is a Greek one signifying a concealed marriage and, is applied to ferns, lycopods, lichens, hepaticœ, \&c., because the manner of their reproduction was long unknown. Though they bear vessels containing what was supposed to be seeds, because from them fresh plants grow, yet these vessels spring directly from the substance of the parent plant without anything which, by the wildest stretch of imagination, could be regarded as a blossom, to account for them. Though, therefore, these vessels were, and for convenience still are called "fruit," it was certain that they were not true fruit, as these last can only be developed from the female organs of a blossom; and, as we have said, there are no blossoms on cryptogams. It appears to be a fixed law of nature that the reproduction of all organic life (except, perhaps, in some of the very lowest forms in which it has not yet been detected, though it may still be so) shall spring from sexual union. The idea of what is termed Parthenogenesis, i.e., reproduction without male agency in some insects, is being dispelled in the light of further scientific discoveries. It is found that, in some cases, one male fertilisation seems to operate through several generations of females, though it is now doubted whether this is really so. In others, fertilisation occurs at an early stage, before the insects reach maturity 
and their perfect form; while in others, again, as in one of our N. Z. scale insects, the male animal passes its whole life within the body of its parent, and thus till lately escaped discovery. Creatures, too, which were formerly supposed to be utterly distinct turn out to be earlier or later stages of the same thing; and the discovery of what is called "the alternation of species" has solved some of the difficulties. In the case of most of our garden flowers and cultivated fruits, the male and female organs are contained in the same blossom; an arrangement which tends to promote fixity of type through successive generations, varied only by accidental or intentional hybridisation. In some cases, however, such as melons, cucumbers, pumpkins, nuts, conifers, $\& c$., the male and female organs are situated in separate blossoms on the same plant: and in others, such as hops, some of our N.Z. forest trees, and one of our grasses, the male and female flowers actually grow on separate plants. In both these last cases, the pollen (fertilising dust) of the male organ of the one blossom has to be carried by the wind or by insects to the female organ of the other, in order that the latter. may be fertilised and the fruit be developed. In the cryptogams, however, no male or female organs could be discovered; and though reasoning from analogy, it was inferred that the bi-sexual law applied to them also, where it came in or how it operated was a mystery; and hence the term cryptogam. It is only of late years that, by persistent microscopic observation, the mystery has been solved, and the extraordinary discovery made that the spores (supposed seed) of cryptogams are actually the germs of blossoms which develope after leaving the parent plant, though germs of all other blossoms would die if similarly removed. Spores of ferns are so minute as to be hardly distinguishable by the naked eye, unless in large quantities, when they appear as reddish brown or black dust; or, in autumn, as a reddish brown scum upon water. Seeds produce plants directly: spores do not. All true seeds contain a tiny germ which developes into the future plant, but the bulk of their mass consists of food for that plant in its early stages; in, fact, a seed is a vegetable egg. When subjected to the requisite conditions of heat and moisture, a seed swells and bursts its skin or shell. The germ then protrudes and sends roots downwards; and when these have got sufficient hold to sustain the young plant, it begins to push its way upwards, usually carrying the food store up with it in the form of seed-leaves, which not only supply nourishment themselves but gather a farther supply from the atmosphere. Nothing of the kind, however, occurs in the case of the spore of a cryptogam, which is a mere cell of vegetable matter without any interior germ or separate food supply; and which seems to have the power of growth all over it and in any direction according to circumstances. It sends down no true roots, but either lies loosely on the ground or other substance on which it falls, or adheres to it merely by some slight viscosity or a few root hairs. Spores of ferns seem to grow better on steep or inclined surfaces than on horizontal ones: for in a fernery, far more young plants 
are produced on the outsides of the pots than on the surface of the mould within them.

The growth of a fern spore into a fern proceeds as follows: When a spore lights upon a suitable substance, it begins to grow, just as the germ of a flower would do while attached to its parent plant, by assuming a green tint, and producing fresh cells connected with itself and with each other, which in turn produce other similar cells, till at length a little green scale-like object is formed, which is actually a blossom of one petal. This is called a "prothallus" which means first of another. Next a tiny bud appears, which is a female organ; and then some minute thread-like objects, which are the male organs, around it. These last bend over the female organ and fertilise it ; no doubt by the shedding of pollen, though this is too minute to be detected even with a powerful microscope : and then the bud sends down true roots, and soon afterwards the first tiny fronds spring upwards. Except in the case of a few ferns, which are annuals, and in which the growth is therefore more rapid, the whole process usually occupies from eighteen months to two years; so that one can easily understand that it was not easy to trace it all through and unravel the mystery, particularly as the several organs are so minute and the mode of development was so unusual and unexpected.

As has been indicated, other plants besides ferns are cryptogams, and it is necessary to distinguish the ferns from these. Plants are divided botanically into three great classes, viz., Exogens, in which branches, leaves, blossoms, and the ultimate fruit proceed from buds growing out of the bark; Endogens where, as in grasses, cereals, and palms, the growth is from within, each blade or leaf forming, at first, a sheath to protect its successors which originate in the very heart of the plant; and Acrogens, in which the growth is from the top alone. Ferns belong to this last class only; but still something more is needed to distinguish them from other acrogenous cryptogams. This is found in the fact that they contain woody fibre, and in the nature and position of their fructification, which consists of capsules (generally spherical, spheroidal, or oval, unless growing so closely together as to press each other out of shape), which contain the spores, and which are placed on the edges or underside of the fronds. These capsules are sometimes bare and grow either singly or in lines or groups ; or are arranged on or around a kind of stem called a "receptacle," and sometimes protected by coverings of various forms ; and it is according to these circumstances, and the manner in which the capsules open when ripe to shed their spores, that the various tribes and genera of ferns are classed.

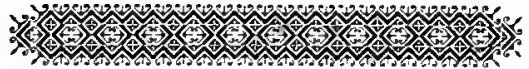




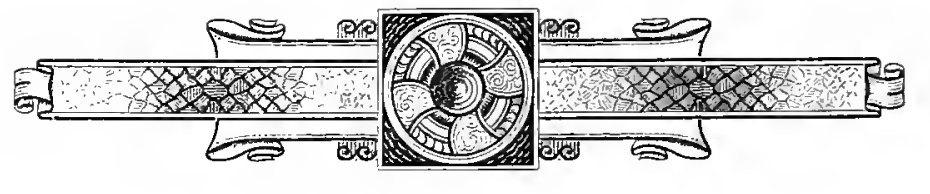

\section{PARTS OF FERNS.}

I INTEND generally to use the ordinary scientific terms, partly for conciseness and partly to accustom my readers to them so that they may understand them when they meet with them elsewhere, I shall now describe the several parts of ferns by name, beginning from below and working upwards. What non-scientific persons are apt to regard as the root of a fern is called the rhizome (ri-zo-me). It is not a root, however, but analogous to the butt or bole of a tree, or the creeping stem of an ivy, the real roots being threadlike fibres of varying thickness, which grow out of it, and which are generally clothed, particularly at their ends, with a sort of short fur, by means of which they absorb moisture for the nourishment of the plant. The rhizome, particularly when it creeps or is otherwise elongated, is usually similarly clothed.

Rhizomes are of various kinds. The simplest form is that which grows "erect" and produces its fronds in a crown or tuft at the top; in which case the plant is called a "crowned" or "tufted" one. In many ferns, this erect rhizome is prolonged above ground to a great height, as in tree ferns, and it is then called a "caudex." This caudex (plural, "caudices") is always clothed with fibrous rootlets by means of which moisture is imbibed from the atmosphere and helps the upward growth of the plant. The number of fronds which form the crown of the plant depends very much on the number of these aerial root fibres, our Dicksonia fibrosa, for instance, in which the actual caudex is only about two inches thick, while the fibres form a felted or interwoven mass, sometimes two feet in diameter, having often as many as forty fronds in its crown. Some caudices have a large conical base of root fibres; and in others this cone extends to the very top of the caudex, which is then of no great height, the whole 
mass being called a "rootstock." Sometimes an erect rhizome or caudex becomes flattened at the top and produces a great number of fronds, while at others it becomes divided into two or more branches, each of which produces a separate crown; and occasionally fresh crowns burst out of the side of a caudex. It is not quite certain how these originate. In some cases it appears to be the nature of the fern to divide itself in this fashion; in others, it seems as if young plants had grown on the face of a caudex; while in others it occurs by accident. I watched a case where a falling tree strained a supplejack tightly across the crown of a tree fern; with the result that the next spring the plant produced two crowns, one on each side of the supplejack, and thenceforth was forked. I have seen a cyathea dealbata with five branched caudices and crowns, and an aspidium aculeatum with seven, varying from three feet to five feet high. In the Philosophical Transactions for 1886 , there is a drawing of a Hemitelia Smithii with sixteen crowns; and Mr. Buchanan, who met with it, mentions that many others near it were much branched. Sometimes one form of a fern exhibits this tendency to divide itself, while the others do not, or do so in less degree; and when it occurs, the several crowns may be separated and grown as distinct plants, when they will probably again divide.

In other cases, the rhizome creeps along, sending out single fronds as it goes. Sometimes these fronds form a single row and at others two or three. In some ferns, as in most of the Hymenophylla, it is a mere wiry thread from which similar ones branch out right and left at intervals, till the ground or tree on which the plant occurs is covered with an interlacing mat, the fronds from which clothe the whole surface. Sometimes these creeping rhizomes are thick and fleshy, and in some cases, as Polypodium Billardieri, are often half an inch in diameter; and in Pteris aquilina (the N.Z. bracken) even thicker; and though more or less fibrous, so full of starch that they formerly supplied the Maoris with a very large portion of their food. Some of them climb like ivy, holding on by their roots, and in this way ascend to great heights on our tree-trunks, which they clothe with fronds. In some cases, the fronds from creeping rhizomes spring up at considerable intervals, while in others they grow so close together that the whole plant, till carefully examined, may be supposed to be a tufted one. In this last case, the rhizome itself creeps but little and slowly. Sometimes one form of a fern will creep rapidly and another very slowly; and as this difference is usually accompanied by some difference of foliage, it may be questioned whether the two forms should not be separately classed. Sometimes a creeping rhizome, instead of sending up single fronds at intervals, sends up erect rhizomes with crowns of fronds on each; and these again occur sometimes at long intervals and sometimes so close together as to make the plant appear to have merely an erect branched rhizome.

In one case (Marattia fraxinea), the rhizome is a large fleshy tuber with fleshy 
roots, and was formerly eaten by the Maoris; and in two others (Adiantum diaphanum and Nephrolepis cordifolia) the true roots produce little tubers full of starch, which would no doubt make good food if only they could be gathered in sufficient quantities, as the tubers of the latter are said to be in the Pacific islands. In some ferns these tubers will produce plants. The rhizome of Lygodium articulatum climbs along, sometimes for hundreds of feet, and ascends to the tops of the highest forest trees, hanging in graceful festoons from bough to bough; and is so hard and tough that the Maoris made it into fish-hooks, and used it for ropes: while the Alsophila Colensoi has what can only be called a decumbent caudex. One tribe of ferns. the Ophioglossaceæ, can hardly be said to have rhizomes, as the fleshy roots branch out immediately below the surface of the ground. An English fern, "Lastrea cristata," though it appears to have an erect rhizome, continually shifts its position. Take what pains one will to put it exactly in the centre of a pot, in a few months it will travel to the side; and if left alone will burst the pot in its efforts to escape. The real fact is that the rhizome is actually a slowly creeping one, but the fronds grow erect from its end, and so it looks as if the rhizome were erect. It will be worth while to note whether any of our N. Z. ferns have the same habit ; Asplenium umbrosum, particularly a Wanganui form of it, appears to have it. From the above it will be seen that there is much to interest an observer even in so humble and often inconspicuous a portion of a fern as the rhizome and roots.

The principal or leafy portion of a fern consists of "fronds," leafy branches so called because they partake of the characters of both branch and leaf. They vary greatly in size, those of the largest tree ferns and some others attaining the length of from ten feet to twenty feet; while those of Hymenophyllum Cheesemannii and Trichomanes Armstrongii seldom, if ever, exceed half an inch. Ferns are classed according to the character of their fronds ; the position and nature of their fructification determining their tribe and genus, and the other peculiarities the sub-genus and species; the specific name often describing some main peculiarity, though in many cases it is that of the discoverer of the plant or given in compliment to some one.

The stem of a frond which connects it with the rhizome or caudex, and resembles the stalk of a leaf, is called the "stipes" (sti-pes : plural, sti-pit-es). It varies greatly in colour and other particulars in different ferns, and often has a groove or channel along the whole or part of its upper surface. The continuation of it to the top end of the frond is called the "rachis" (ra-kis) and sometimes the "mid-rib." This latter term is also applied to the central stems of the lateral branches of fronds, but the correct botanical name for such a stem is a "costa" (plural, costæ). The term frond, therefore, though often used to express all above the rhizome, applies, strictly speaking, only to the leafy portion. When a frond consists merely of one even-shaped leaf, as it were, it is called "simple," "entire," or undivided"; though its edges may be 
slightly indented in various ways such as "serrated," which means toothed like a saw; "fimbriated" when the serration extends as corrugation within the edge ; "crenate," hollowed into rounded notches; "crenulate" when these notches are small; and "lobed" when the projections between the notches are more or less rounded. As the first two of the above terms are often used, in other senses, in reference to parts of fronds, I shall follow the Synopsis in employing the word "undivided"; though even this is hardly a satisfactory one, because division begins as soon as an edge is broken. "Serrated," "crenate," \&c., are also used in respect of the edges of the sub-divisions of fronds as well as those of whole ones; and when an edge is not indented in any way it is said to be "entire." A margin is called "curled" or "crisped" when it is waved up or down like the corrugations of roofing-iron. When the edge of a frond, or of any portion of it, is indented right down to the midrib, it or that portion is said to be "pinnate," and the projections between the indentations are called "pinnæ" (pinna, in the singular); but if the indentations stop just short of the midrib, it is called "pinnatipartite" (pinnately divided), or about half-way, "pinnatifid" (pinnately cleft) ; and the projections are either "pinnæ," "pinnules" (pin-nu-les), or "lobes," according to their depth, in proportion to their width, their situation on the frond, and their being rounded or pointed at the ends : the first term being more applicable to the pointed ones. If the pinnæ are again sub-divided, right down to their midribs, the frond is said to be "bi-pinnate" ; and if a third or fourth division occurs, it is "tripinnate" or "quadripinnate"; and the same with the other terms. Beyond this, a frond is said to be "de-compound"; and this term is sometimes used even to tri and quadripinnate ferns. It must be clearly understood that these terms apply to the largest and most divided part of a frond. The upper end of a frond is usually less divided than the lower one; and some fronds taper both ways, in which case they are usually most divided just below the middle. They also apply to large fully-developed fronds on old plants, as the smaller fronds on young plants are usually less divided. It is necessary to bear this in mind, as otherwise anyone gathering a frond less divided than the description says, might fail to identify it. The end portion of a frond, beyond where the lateral pinnæ branch out right and left, is called the "terminal pinna", and the same term is used to express the end portion of a main pinna when the frond is bipinnate or more divided. The end part of a pinna, particularly of a secondary or tertiary one, is similarly called the "terminal pinnule." The terminal pinna or pinnule usually tapers down, being first pinnatipartite, then deeply pinnatifid, then less and less so, and then merely lobed, till it ends in a point or tail. The ultimate divisions of a frond are called "pinnules" (pin-nu-les, little pinnæ) or "segments." The former term applies most strictly where, as in the Adianta (maidenhair ferns), they are of a leaf-like character; but it is also employed in the other cases, for want of a better one. Pinnæ and pinnules are sometimes connected with the rachis or midrib of the 
next larger division of the frond by stalks; but in other cases by bases of greater or less width, when they are said to be "sessile," that is, seated. This term is also used to express any other part which is connected with the body or next larger division of a frond by a base instead of a stalk; and any which is more or less enclosed in the body of a frond, particularly in its edge, is called "inserted" ; while such as project are "exserted." Anything growing in a hollow in the surface of a frond is said to be "depressed," and anything standing above it "elevated." The upper angle formed by the junction of any two parts of a frond is called an "axil," and anything growing in it is termed "axillary."

On looking at a frond, one sees lines of woody fibre traversing it, and forming a sort of ribbed framework, to stiffen the thinner portions. The lines are "veins," and the total of them the "venation." When veins run direct from the midrib of any part of a frond to its edge, they are "simple" or "free"; but they often divide, in which case they are "forked." Small secondary veins are "veinlets," or "venules" (ve-nules), and when these, after dividing, join again, or unite with another vein so as to form a sort of network, they are called " anastomosing" (anna-sto-mo-sing), and the spaces enclosed by them "areoles" (a-re-o-les). The veins are sometimes very distinct, but in other ferns scarcely traceable by the eye. They exist, however, and are conniected with the fructification, the manner of the connection being one of the points to be noticed in classing ferns. Mr. Smith, of Kew Gardens, first pointed out this connection; and by it fossil ferns, which showed no trace of fructification, have been classed.

The portion of a frond which contains the spore-capsules is called a "sorus" (plural, sori), and is variously placed in the different sub-orders and genera of ferns. Sometimes it consists of single capsules, at others of groups or lines of them, each capsule standing alone; and either bare or protected in some way. In other classes it consists of capsules closely packed together round a central stalk called a receptacle; and this cluster of capsules may be either naked or enclosed in or protected by a covering of some kind. In others again the capsules are piled in little heaps, which may be round, oval, curved, or in straight lines, and in the several classes are, or are not, protected while young and tender by a covering; the manner in which the covering opens to allow of the growth of the capsules being one of the means of identifying ferns. The covering which protects a sorus is called ail "involucre" (in-vol-u-cre) or "indusium" (in-du-si-um). Properly speaking, the former term applies where the covering is wrapped over or round the sorus, and the latter to the other kinds, but the words are used interchangeably by different writers, and sometimes even by the same person. In fact, the manner in which a sorus is protected varies in so many ways that it would be hard to say in some cases which term is the more applicable. As "involucre" is the term used in the Synopsis, I shall generally use it 
too. When an involucre grows out beneath a sorus, and its edges, after rising round the outside of the sorus, meet above and enclose it, it is said to be "inferior"; but if it from the first appears above the sorus and covers it, and thus the capsules grow out from under its edges, it is said to be "superior." Sometimes it is necessary to examine fronds at different stages of growth, as a scale-like involucre, which completely covers and protects the young capsules, is often buried and lost sight of among them as they attain maturity. In some cases, too, there are hairs intermixed with the capsules. Capsules are usually surrounded by an elastic ring, which causes them to burst open when ripe so as to shed their spores; the manner in which the capsules open being another means of identification. In the various classes of ferns the sori are "depressed," " inserted," "exserted," "sessile," or "stalked," so that there are plenty of clues to the identification of a plant if one will only take the trouble to use them, and -. to those who will do so the study soon becomes extremely interesting. One of the most curious things that can be shown to children is the following: Get a nearly ripe frond of a fern, or piece of a frond of a tree fern, and let it lie on a sheet of paper till the capsules burst and shed their spores, which look like brown dust. On looking at this dust through a magnifying glass it appears alive, the rings which have burst the capsules and then become detached from them coiling and uncoiling like animated watch springs and jumping about like cheese hoppers. This action, occurring naturally on the growing frond, scatters the spores abroad, just as the sudden bursting and curling of the ripe pods of gorse, peas, broom, balsams, \&c., scatters their seed to a considerable distance. I know nothing more calculated to impress on a child's mind that there is actual life in a plant than seeing these rings moving of themselves. The term "hairs" explains itself ; but "scales" are hairs with flattened bases, of greater or less width; and these, when of a light brown or straw-colour, are said to be "chaffy." When long, narrow, tapering to a sharp point and slightly bent, they are called "subulate," from the Latin word subula, a shoemaker's awl. Hairs and scales are often connected to the frond by a sort of joint; and in this case generally fall off after a while, as the frond ripens, in which case they are said to be "deciduous." Sometimes, too, they get darker in colour as the frond matures; so my readers must not be misled by an apparent difference, in this respect, from the description. A part of the leafy portion of a frond continued along the rachis or a midrib is called a "web" or "wing." The texture of a frond may be either "membranous," "filmy," or "diaphanous," when thin and transparent; "herbaceous" when soft, opaque, and bright-coloured; or "coriaceous" when tough and leathery-looking. "Glabrous" is shining or polished ; "hispid" bristly, "hirsute" having soft hairs, "villous" or " pubescent," downy; and "pilose" having a few hairs. Anything on the upper side of a frond is said to be "superficial"; anything on its edge "marginal" ; on the ends "terminal" ; and on the back "dorsal." 
Sometimes fronds are "forked," or divided into several branches; and at others they have the ends of the frond itself, and of the pinnæ, divided in to tassels, and are then called "crested." In other cases, again, parts of the frond are diminished in size, or altogether wanting, and these fronds are said to be "depauperated." In these ways very curious variations of form occur. They are less frequent in our N. Z. ferns than in English ones; but still they are oxcasionally met with, and. appear to be often merely accidental. In England. such varying forms have been transplanted and cultivated; and thus the varieties have become fixed, and multiplied in number. In one case, a N. Z. fern (Aspidium aculeatum) becam a beautifully crested in $\mathrm{m}_{\gamma}$ greenhouse; but the effort seemed to exhaust the plant, and it died; but I have now two slightly crested plants of Pteris tremula, and some others with foliage curled almost like parsley. Mr. Colenso records branched forms of Asplenium flabellifolium, and Lomaria fluviatilis ; the late Mr. Potts found a branched form of Lomaria procera; and I lately saw similar ones, as well as crested forms of Dicksonia squarrosa, Lomaria discolor, Lomaria alpina, Asplenium falcatum, Aspidium aculeatum, Aspidium Richardi, and Nephrodium molle in cultivation at Christchurch and Dunedin. These abnormal forms seem more common in the Middle Island than in the Northern one, or they have been more sought for and preserved. Near Dunedin there is a form of Aspidium aculeatum, which was till lately supposed to be confined to Tasmania. It has buds all along the upper side of the rachis, and each bud will produce a fresh plant. Another form of the same fern produces one large bud, on the under side of the rachis, just where the lateral pinnæ end, and the terminal one begins. This bud produces fronds, and as the original or parent frond begins to wither the weight of the bud bends its end down to the ground; when the bud takes root, and a fresh plant results. An English florist advertises crested forms of Lomaria discolor and Aspidium Richardi; though how he obtained them is not known. At intervals of many years, some plants of Polypodium Billardieri produce bipinnatifid fronds, instead of merely pinnatifid ones, and are most lovely in appearance. I have one such at present, and purpose raising plants from the spores of the bipinnatifid fronds, to see if the type can be fixed: as has been done in the case of the English Polypody, a similar form of which, known as "variety Cambricum," has been thus perpetuated.

I have so often been asked my opinion on what is called "Darwinism," and whether it is borne out by our N. Z. ferns, that it may be well here to state the result of my observations. Transition forms of species of the same genus are constantly found, and are often difficult to class : even sub genera seem to merge in one another; and occasionally a plant of one genus may, at first sight, be mistaken for one of another. Thus at Dunedin there is a form of Hemitelia Smithii so exactly like Cyathea medullaris, with white scales instead of black, that almost any one might be deceived by it: yet the normal forms of the plants are totally unlike, and the latter 
does not now grow within nearly 200 miles of the place where this apparent connecting link occurs; though, as it is found at Stewart's Island, it may have done so at some remote period. Though the eastern side of the Middle Island is now nearly treeless, the quantity of old roots and logs found in swamps proves it to have been once a forest region, and C. medullaris probably occurred there. There is also a distinct sequence of form traceable throughout the whole series of orders, tribes, genera, and species; but no clear proof of even new species originating. When, however, a number of prothalli grow so close together that they are forced to stand on edge as it were (and this often happens) it is evident that their sexual organs may intermix, and hybridisation occur : and thus intermediate forms may arise, and may have done so.

It would be well to thoroughly master the terms which I have given above, as they are in constant use, but the following definitions of the terms often met with in scientific descriptions will also be found useful :-

Acute-Pointed.

Acuminate-Long-pointed.

ACUlEATE-Prickly, or prickly-looking.

AdNate-One part being joined to another, or projecting from it.

ADPRESSED-Pressed against.

Alternate-Branching right and left, but not opposite.

Apex pl. Apices-Tip of a frond, pinna, or pinnule.

Articulated-Jointed : usually with a knot.

ATtENUATED-Slender: narrow.

AURICLE-An ear-shaped lobe, usually at base of frond or pinna.

BIFID-Cleft in two.

Caudate-Tailed.

Ciliated-Having fine hairs.

Circinate-Coiled, as a very young frond is, till it unrolls.

Clavate-Club-shaped. Thickened upwards, with rounded or flattened top.

Compressed-Packed together. Flattened. Narrowed. Shortened.

CONFLUENT-Growing towards, or into each other.

Connate-Firmly grown together.

CORDATE-Heart-shaped.

Costate-Ribbed.

Cuneate-Wedge-shaped: usually when the point is downwards.

Deciduous-Dying in winter. Falling off after a time.

Decumbent-Lying down, but with the end turned up.
Deltoid-Triangular.

Dichoтомоus-Branching into pairs.

Digrtate-Divided in to finger-like points.

Dimidiate-Divided into unequal halves.

Distichous-In two opposite rows.

Divaricate-To branch obtusely.

Elliptic-Usually oval, rather than truly eiliptical.

FalCate or ENS1FORM-Sword-shaped. Curved and tapering.

Ferruginous-Rust-coloured. Brownish red.

FILIFORM-Thread-like.

Flabellate-Fan-shaped.

FLACCID-Weak. Unable to stand erect.

Flexuous-Bent about. 'Winding. Twisted. Zigzag.

Fulvous-Yellowish brown.

Glabrous-Shining.

Glaucous-Soft pale green. Whitish or silvery.

Imbricate-Overlapping. One over the other like tiles on a house.

Involute-Rolled inwards from the sides.

Lanceolate-Lance-shaped. Tapering to both ends.

LoBule-A little lobe.

LUNATE-Like a crescent, or half moon.

LYRATE-Like a lyre in shape.

OBCORDATE-Like a heart upside down, or ace of spades.

Ovate-Egg shaped.

Obovate-The same upside down.

Opaque-The opposite of transparent.

PEDICEL-A stalk; usually a short one. 
Pendulous-Drooping. Hanging down.

Persistent-Not falling off.

Proliferous-Producing young plants or buds on frond itself.

Prostrate-Lying down.

Recurved-Bent back.

RENIFORM-Kidney shaped.

Reticulated-Net-fashion. Meshed.

RETUSE-Having a broad, blunt, or indented end.

Revolute-Rolled back.

SCABrous-Covered with short hairs. Rough.

SCABERULOUS-Slightly rough.

Serrulate-Finely toothed.

Setose-Bristly.

Sinuate-Wavy. Having rounded projections and hollows alternately.

Sinus-An indentation

Soriferous-Sorus-bearing

Spathulate-Broadest at top. Opposite of tapering.
Spinous-Thorny.

Souarrose-Rough. Scaly.

Stellate-Star-shaped. Tops of hairs are sometimes so.

Stipitate-Stalked.

Strigose-Having coarse hairs, all lying one way.

Sub (as sub-acute)-Almost. Approximating to.

Subulate-Narrow, tapering, sharply-pointed, and slightly bent, like a shoemaker's awl.

Terete-Cylindrical.

Ternate-Divided at once into three branches.

Tomentum-Short close down; like very shortpiled velvet.

Tomentose-Covered with tomentum.

Truncate-Cut short off.

Tubercles-Warty projections.

URCEOLATE-Urn-shaped.

Viviparous-Producing young plants on the fronds.

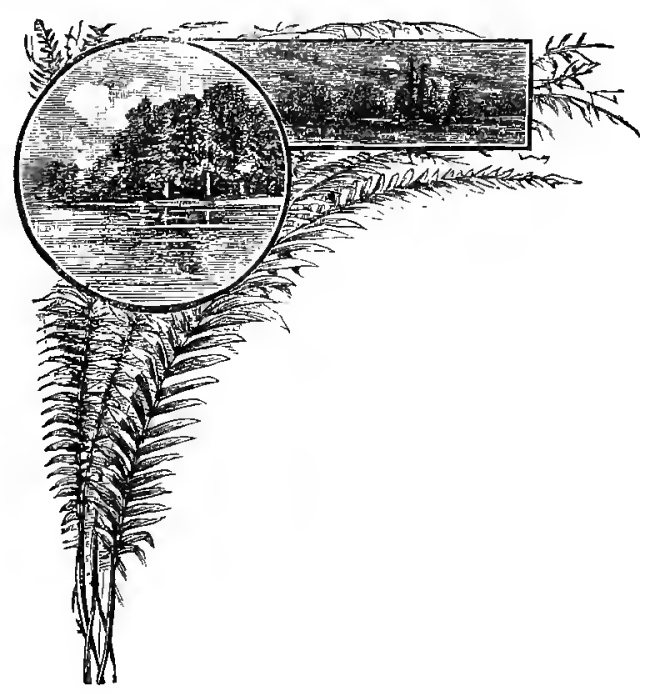




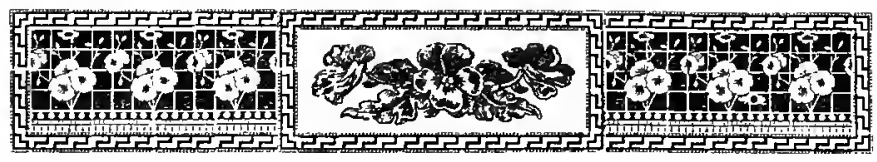 \\ CLASSIFICATION OF FERNS.}

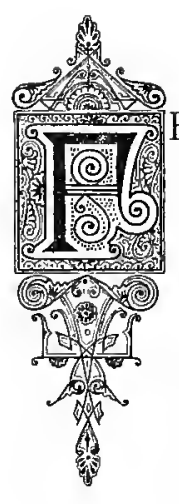

ERNS form the Botanical order "Filices," and are divided into "Suborders," which again are divided into "Tribes," each of which includes a number of "Genera," and each "Genus" many "Varieties" or "Species." I shall only notice the New Zealand ones. If you have gathered a fern frond, and wish to know what it is, the first thing to be done is to look for the sori; as an examination of these will tell the sub-order, the tribe, and genus to which it belongs. If it has no sori, look for a fertile frond on the same plant; or if there are none there, on a similar plant adjacent, so as to get this clue. Reference to the Genus will probably show that it is divided into two or more "Sub-genera;" and the sori and venation will show you to which of these again it belongs. A Sub-genus also is often again divisible into classes, by some peculiarity of the foliage or growth; and thus at last you have but a very few kinds from which to choose; and the description of the plant will soon show you which of these it is. Instead of a difficult task, the identification of a fern is almost as easy as naming a card out of a pack. If you have any doubt, just examine several fronds at different stages of growth, and your doubt will be ended: unless you have been so fortunate as to find a new plant: in which case, you will be pretty sure to know that too, or at all events to suspect it, and be led to compare notes with other filicists, as collectors of ferns are called. The only cases likely to puzzle you are peculiar or transitional forms : and these, as I have said, are rare in New Zealand.

It may be well here to say a few words respecting the use of the terms " axillary," "marginal," or "terminal" in reference to sori; as they may give rise to the idea that a sorus is a more distinct part of a frond than it really is. A fertile portion of a frond is merely a changed form of a similar portion of a barren one, the sorus being actually developed out of the latter, which becomes narrowed or shortened, apparently to supply material for the sorus. The terms "marginal" and "terminal" explain themselves; but "axillary" hardly does so, as it seems to indicate that the sorus is a separate growth placed in the axil. This is not the case. When the term is used, particularly in the case of the Hymenophylla, the sori so spoken of are actually 
terminal on lobes growing next to the axil, and so much shortened as to be almost obsolete, so that the sorus looks at first sight like a separate growth. It may be well also to note that, though many of the ferns will be found to be described as having creeping rhizomes, this usually only applies to well grown plants. All ferns, when very young, are tufted plants. It is only after a longer or shorter time that some of them begin to put forth the creeping rhizomes, and so overspread the surface on which they grow. I mention this because, otherwise, some of my readers, on finding a young plant of some species which was described as having creeping rhizomes, and seeing that what they had found was simply a tufted plant, might suppose it to be something different from what it really is. In the plates, any fern of which the fronds spring directly from creeping rhizomes has the rhizome shown: where there is no rhizome shown, the fronds spring from an erect rhizome or caudex. Thus the plates form a guide to the growth of each fern.

There are several ferns respecting which a certain amount of doubt exists, as to whether they are really New Zealand plants or not. They have been reported from one or two localities, but there seems a question whether they have not been accidentally introduced there, as spores from cultivated plants or otherwise. A similar doubt exists as to one or two ferns that have been found in England; but as the fact of these last having been observed growing wild causes them to be included as English plants, and the number of such introduced species is likely to increase rather than diminish, I have judged it best to follow the same rule with doubtfully indigenous New Zealand ones, and to give figures and descriptions of them, in order that anyone who may chance to meet with them may know what they are.

There are also some which have similarly been found in some one locality, and of which descriptions have been furnished by the Revd. W. Colenso, though the specimens from which those descriptions were drawn up have been sent to the Royal Herbarium at Kew. In these cases, I have drawn the fronds from the Revd. gentleman's description and measurements; and though possibly the drawings may not be perfectly accurate, they will, I believe, be sufficiently so to enable any one meeting with the plants, particularly in the localities from which they are reported, to identify them.

Probably some of my. readers will wonder that, as the descriptions of the ferns follow each other in regular order, according to their classification, the plates and figures on them are not arranged in a similar sequence. It may be well therefore to explain, that my first intention was to print the ferns in their natural colours, and they were arranged according to those colours. It was found, however, that to produce such work would make the book too costly for ordinary readers; and as my object in writing it has been to popularise the study of the New Zealand ferns, by enabling non-scientific persons to identify them, I had to content myself with a 
style of lithography which, though new and of a high class character, is less expensive; and to mention the colours in the descriptions.

Plate I., showing the fructifications of the different genera of N.Z. ferns, as they appear when magnified, will be found a sure guide; it being borne in mind that the capsules, in different ferns, vary in colour from straw to nearly black; though those of any one species are of similar hue. Six Sub-orders are represented in New Zealand, viz., "Gleicheniaceæ," "Polypodiaceæ," "Osmundaceæ, " Schizœaceæ," "Marattiaceæ," and "Ophioglossaceæ," the termination "aceæ," indicating a certain tribe or genus and its allies. Thus Gleicheniaceæ includes not only "Eugleichenia" (good or true Gleichenia), but the sub genus "Mertensia" also; as well as some others, of which we have no examples in the colony; and the plate shows both. The Polypodiaceæ again include not only the true Polypodies, but ten other tribes, some of which contain several genera and sub-genera, all of which are shown : and the others in like fashion, so as to make the key complete, there being nearly fifty genera and sub-genera in all in the colony. In each case, the plate shows the whole sorus in its place on a fern, and such details, in the shape of sections of the sorus, manner of its opening, capsules and manner in which they burst, \&c., as may make the printed description perfectly clear.

The following table will explain how the several Sub-orders, Tribes, Genera and Sub-genera are divided as regards our New Zealand ferns :-

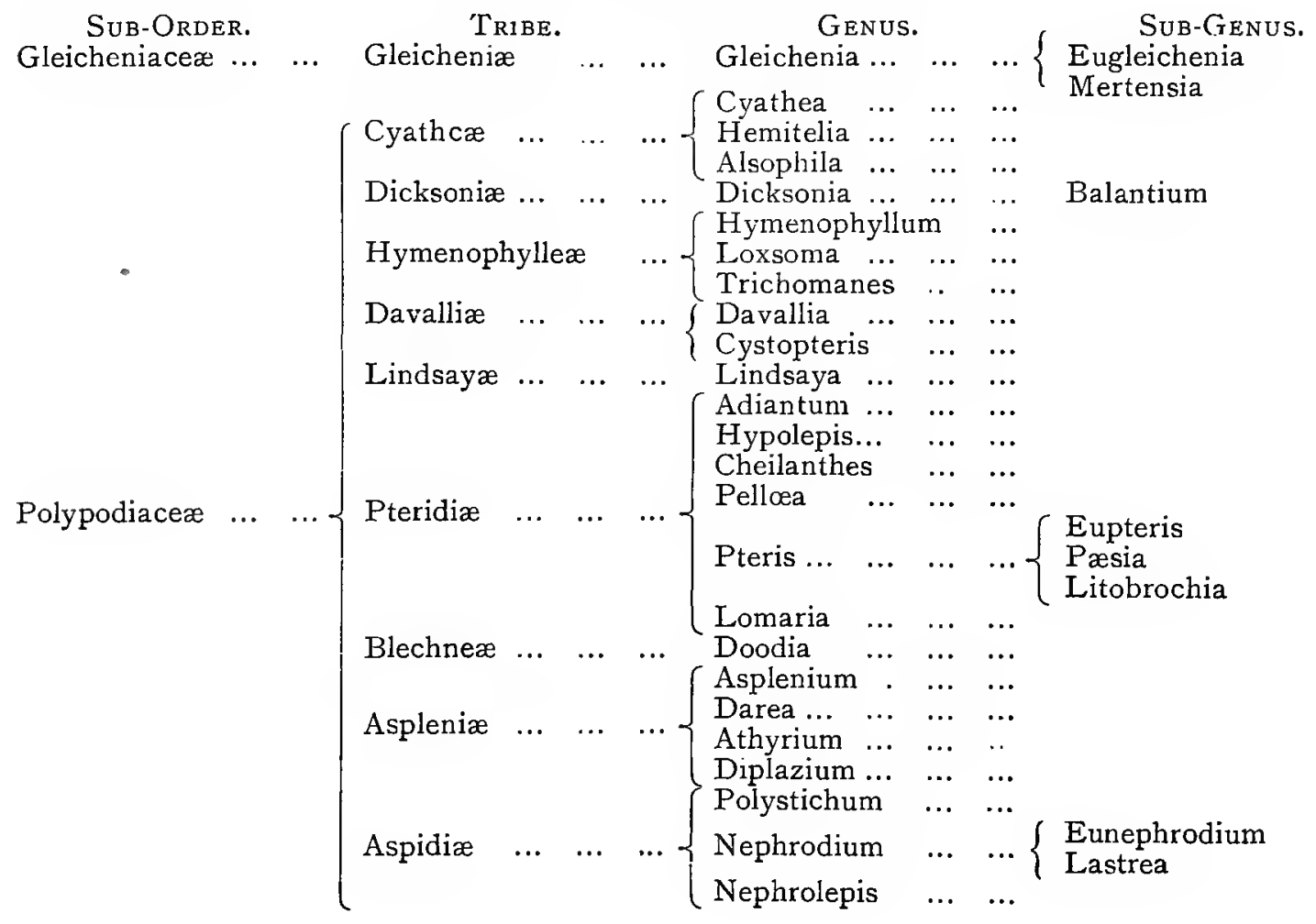




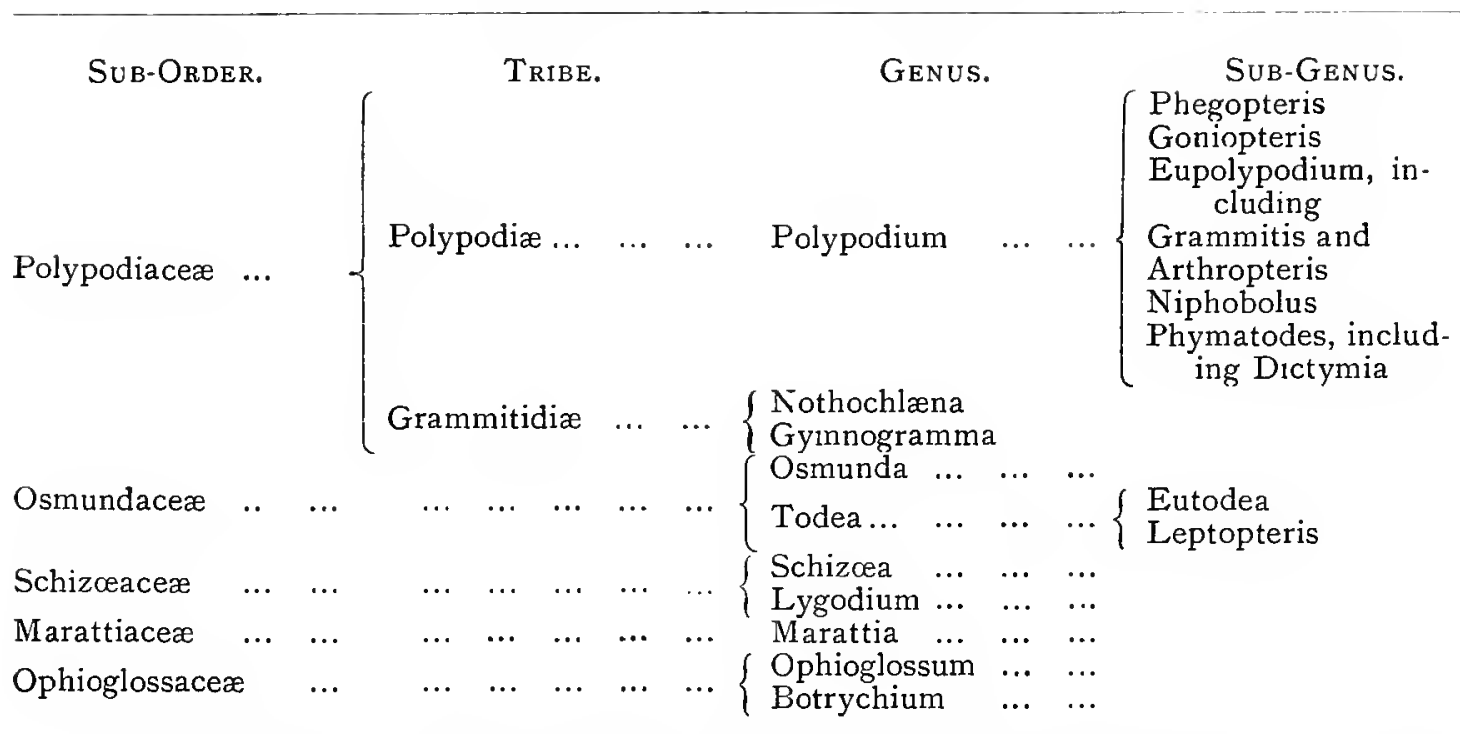

Other writers on ferns divide the several Genera and Sub-genera somewhat differently; but I think it best to adhere to the classification of such high authorities as the late Sir W. J. Hooker, and his successor Mr. J. G. Baker, even though it involves such an apparent absurdity as separating Grammitis and Blechnum from the tribes to which they give the names. As my readers will note, the sub-generic names are dropped, and only the generic ones retained in naming the ferns.

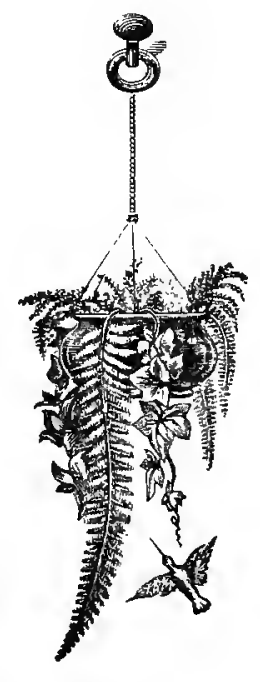




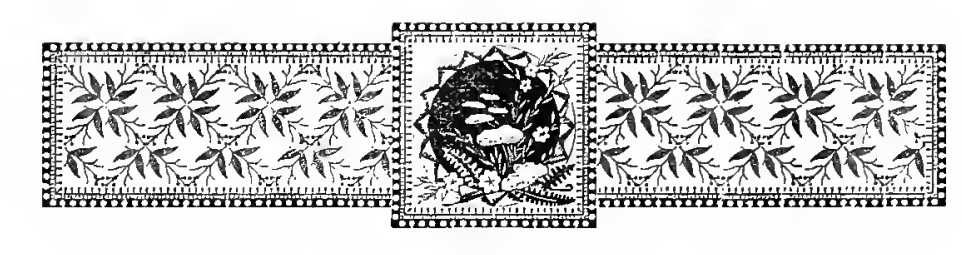

\section{COLLECTING AND PRESSING FERNS.}

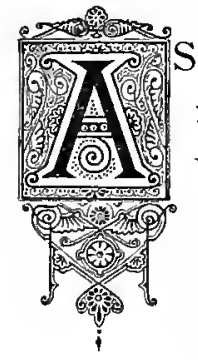

FEW THINGS are prettier or more interesting than nicely pressed and mounted ferns, and their collection involves no very great trouble, it may be well to give a few directions on the subject. Fronds that have no fructification are of little value as specimens, unless they are of kinds that have separate barren and fertile fronds, in which case both will be wanted, and when mounted, should be placed side by side. In collecting them, you will want some sheets of blotting paper, the softer the better. These should be placed between rather hard stiff surfaces, such, for instance, as an old writing-case or blotting-book. This will answer the purpose of those who merely collect a few fronds for amusement, or for some ornamental purpose ; but those who wish to make a proper collection, for botanical purposes, will like to have something better, yet, at the same time, not too weighty to carry about. A good article for their use may be made as follows:- Get two pieces of thin board about eighteen inches long by twelve inches wide, and, at about three inches from both ends, nail strips across them an inch wide by three quarters of an inch thick. These should be placed exactly opposite to each other on both boards, and their ends should project an inch or so beyond the boards. Lay the boards face to face, with a few sheets of blotting paper between them, and couple each pair of the projecting ends of the cross strips together with a strong elastic band. As you gather your fronds, lay them carefully between the sheets of the blotting paper, taking care that they lie flat, without any of their points or edges doubled under, and then shut up the press, and replace the elastic bands. The bands will keep the specimens pressed flat, and prevent their getting curled, as they become soft and limp in their first stage of drying. On reaching home, you should put them in a stronger press made of stouter boards, say, an inch thick and rather larger. You can either 
place these on the floor, with your ferns and blotting paper between them, and then place weights on top; or, better still, you may have a small bolt, with a T-headed nut, through each corner of your boards. The blotting paper will require to be frequently changed, and replaced by dry sheets, particularly at first, and it is a good plan to soak your fronds for an hour or two in weak acetic acid, or strong white vinegar, after they have been drying for a day or two; as this makes them keep their natural colour better ; and then continue the pressing, changing the blotting paper often, till your specimens are quite dry. In changing your blotting papers, see that no edges are turned back; for it is very difficult to avoid this at first. If any are so, straighten them out; for which purpose a lady's crochet hook is a useful tool ; and with a view to this, it is not desirable to press your fronds too hard at first, lest any turned edges should break off in straightening, or should show a mark where they were turned back.

It is not desirable to gather fronds that are fully ripe; as their capsules are apt to burst, and in some cases the distinctive character of the sori will have been partially obliterated by the growth of the capsules. Small perfect fronds, too, are better than pieces of larger ones; but, of course, in the case of larger ferns it would be impossible to press whole fronds; though you may divide middling-sized fronds, and join the portions together in mounting them. When your specimens are thoroughly dry and firm, which, in the case of the larger kinds will be in about a month, but, of course, varies somewhat according to the weather, you can place them in your herbarium, mounted on sheets of cartridge drawing-paper. Label each specimen not only with its name, but with the date and place at which it was obtained. This applies particularly to peculiar or transitional forms, and to tree ferns, some of which, particularly Cyathea Cunninghamii and Hemitelia Smithii, are not easy to distinguish when pressed and dry. For your own private use, and that you may be able to thoroughly examine any specimen occasionally, it is best to fasten them down merely by narrow strips of gummed paper strained across them; but if you wish them for inspection of ordinary and non-scientific friends, who would be likely to handle them carelessly, it is better to mount them in a scrap-book. Neatness is required in doing this, and various means of attaching the specimens to the leaves of the book are recommended. Gum is not advisable, because it dries slowly, and when dry is so brittle that your specimens will be apt to become detached, and get broken. Glue is objectionable on account of its dark colour, though the white fish-glue or gelatine is less so than the common kind, and is very strong. Isinglass is also strong, but expensive. Paste of flour and water with a little alum in it, is approved by some people; but it is liable to be devoured by insects ; and if, to prevent this, you add a little corrosive sublimate, it is apt to blacken your specimens. Dextrine is good, but dries rather quickly. Starch is good, but has the same defect as paste. On the whole, I think isinglass or gelatine are the best of the above for the purpose. A good way to go about the mounting is to spread a thin 
layer of the article which you intend to use on a square of glass or piece of board. Lay your specimen upon it, and press it gently, so as to get the whole of its under surface lightly covered with the adhesive matter. Then lift it again, and lay it on your mounting paper, and press it firmly till it adheres securely. You must, of course, have one page perfectly dry before proceeding with the next; or you will have the pages sticking together, and the book should be kept in a thoroughly dry place, as otherwise damp may cause the leaves to stick. Another way is to lay your frond on the page and secure it by weights. 'Then spread the adhesive matter on a thin piece of flat zinc or knife blade, and slip it under each part in turn, working it to and fro a little. Then, as you withdraw the zinc, that part falls on its place and sticks there.

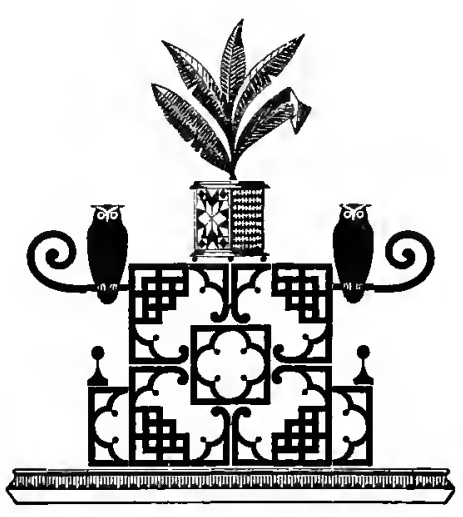




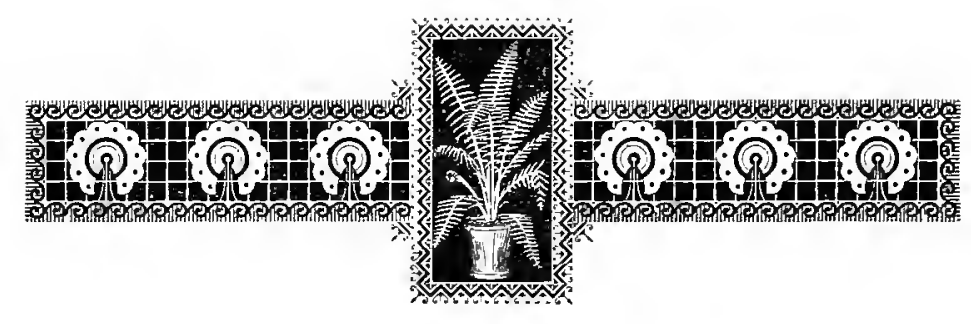

CULTIVATION OF FERNS.

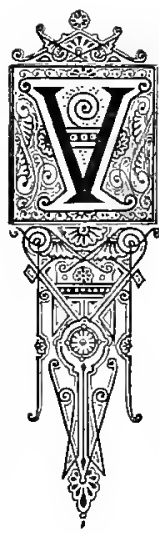

ERY many people try to grow ferns and after a little while they give it up in despair. They say: "I cannot get ferns to thrive. At best they only struggle along for a while and then die ": and the reason why this happens is not far to seek. Ferns, as a rule, love shade and moisture; and must have these, or they will not thrive. Most kinds, too, hate wind : it breaks their tender fronds, blackeris their edges, sucks up the moisture from the soil in which they grow and so checks the growth, if it does not kill the plants. Their natural home is the depths of woods and forests, where sun and wind cannot penetrate and where the atmosphere is always pure, cool, and damp : yet people place them close to sunny windows, and then create a draught by leaving the windows open. In many cases, too, the room is lighted with gas, which dries and poisons the air within it. If the plants throve under such unnatural conditions they would have a power of accommodating themselves to altered circumstances to an extent far beyond any other living organism. There are a few ferns which grow in dry exposed situations, but only a few, and these require to be grown under similar conditions, as much damp injures them; but still they want pure air, as they are generally mountain or seaside plants.

If you want to get a fern to grow, you must note the conditions under which it naturally occurs; and imitate those conditions as closely as you can. This does not refer merely to such matters as soil, shade, and moisture, but to other things as well. For instance, if the plant has an erect rhizome, with a crown of fronds, note how that crown is situated, in reference to the surface of the soil. As a rule, it stands well above it, and if, in planting the fern, you put it under ground, it will very likely rot ; or the young fronds will be so exhausted and strained in the effort to force their way 
upwards through the mould, that they will be distorted in form and never attain their full development. If the fern has a caudex, you may plant it a little deeper than you found it, because in this case the lower aerial root-fibres will develop into terrestrial ones, but it is not advisable to plunge the plant too deep.

If the fern has a creeping rhizome, notice whether that rhizome is under ground, or merely creeps among the moss and dead leaves on the surface. In this latter case, it will be useless to plunge it beneath the soil, as it will rot, or the fronds will not come up healthily. You must arrange the rhizome, and peg it down on the surface of the earth in the pot, and cover it with leaf mould, dead leaves, and other vegetable matter. Fine sawdust, or, better still, rotten wood pounded fine, is a good top dressing; as it absorbs and holds a certain amount of moisture, sufficient for the needs of a fern, yet not too much. If your soil be clayey, it will be well to pound it to powder, and mix it with half as much of the sawdust or pounded rotten wood. This will lighten the soil, so as to enable the roots of the fern to penetrate it easily; and, at the same time, hold moisture, and prevent the ball of earth getting hard and impervious to water. It is well to mix the same, and particularly the rotten wood, with sand in which you propose to grow ferns. Some ferns grow only on tree trunks and rotten logs, holding on by their roots; or among moss; and it will be almost useless to plant these in earth. Others grow on the surface of swamps, and others again have their rhizomes creeping among stones, and in the crevices of rocks, and will thrive best if planted in a similar manner. It really seems, in some cases, as if the tighter the rhizome is jammed between rocks the better the fern grows and the finer fronds does it produce.

Others, again, have a decumbent rhizome: that is, the rhizome, though perhaps only a short one, lies flat, but with the soft new end turned up. As the wood ripens and hardens, it lies down, and the new growth which lengthens it turns up in its place. Such a fern must be planted in this fashion, or it will not thrive. I, some years ago, bought a healthy looking fern from a Wellington florist, but found it would not thrive. It just kept alive and that was all. At length, on looking at a description of the fern, I saw it was stated to have a prostrate rhizome. Acting on this hint, I repotted the plant in a proper position and it has grown well ever since. In another case, I have tried for some years to force a New Zealand fern, which has a decumbent rhizome, but is said occasionally to produce a caudex four feet or five feet high, to do so, but utterly in vain. The upper part of the rhizome always bends over and travels across the pot. At present it is forcing out the side of the pot rather than grow upwards.

Of course, there are some ferns which grow under conditions almost impossible to imitate: such, for instance, as grow at high levels on our mountain sides, where they are covered up with snow for several months every winter, and during summer are exposed to almost tropical heat during the day and intense cold during the night. Those of my readers who have never ascended a lofty mountain will probably think 
the last clause contradictory, and that the temperature at high levels is uniformly cold. This, however, is not the case. To any one who has traversed our snow-fields and glaciers, it seems wonderful that they do not melt away at once, as the rocks beside them become intensely hot by absorption of the sun's rays during the day. It is a most curious sensation to lay one hand on stene, of which the heat can scarcely be borne, and at the same time plunge the other into snow; yet this can be done on any sunny day in summer, on our high mountains. Our great mountain Ruapehu is merely a vast heap of lava and volcanic sand; and the consequence is that the snow, as it melts, all soaks downwards and comes out in the form of large springs of icecold water around the base of the mourtain. Some of the springs are of such volume, as to form small rivers at once, and beside them, in the full glare of the sun but with its roots washed by the icy water, grows the Hypolepis millefolium, one of our most lovely ferns. It only grows close to the springs, however, and for perhaps a hundred yards down the stream-side. Beyond that distance it is not to be found, the water having apparently become too warm for the fern, though almost cold enough to give toothache to any one drinking it. The fern occurs in similar situations at $\mathrm{Mt}$. Egmont, and other mountains. It can hardly be wondered at that persons should fail to grow it, as one would need a greenhouse and a constant supply of ice to cool the water in which the pot stood. I have several times tried in vain to acclimatise this fern; and plants of it, which I and other lovers of ferns have procured from Otago and Southland, where it grows under less extreme conditions, have all died. Any one, therefore, who should succeed in acclimatising it at low levels in the North Island would have reason to feel proud, and would do well to sow the spores of his plant on the chance of getting it to grow under more ordinary conditions; as its lacelike foliage and bright colour are beautiful in the extreme and greatly resemble those of the "Lace fern," Cheilanthes Elegans, which is so great a favourite in greenhouses. It has been acclimatised at Christchurch, and plants may, perhaps, be got from there. Others, again, grow on the rocks, or in caves by the sea-shore, and require the salt spray, or at any rate sea air, to cause them to thrive. It is a good plan to sprinkle these with salt water occasionally.

Another great cause of ill success in growing ferns is carelessness in taking them up and transplanting them. I have already mentioned that the roots of ferns are furnished with a sort of down or fur at their ends. This acts as a sponge to suck in moisture for the nourishment of the plant. These furry ends consist of the most newlygrown material, and are soft and tender. If, therefore (as is generally done), a person clutches hold of a fern, and pulls it out of the ground, most of these tender root-ends are broken off and left behind, and the plant has to produce more in their place before it can begin to imbibe nourishment from the soil. In the meanwhile, there is nothing to support the fronds, which die; and thus the absorption of carbonic-acid gas 
from the atmosphere (the reciprocal action necessary to supply material for the new roots) ceases and the vitality of the plant is seriously checked if not stopped altogether. Ferns, like all other plants, draw their woody matter mostly from the atmosphere, their fronds acting as lungs, just as the leaves of a tree do. Too much care cannot be exercised in taking up a fern. The earth all around should be carefully loosened and the tender roots set free; or else a lump of earth sufficiently large to contain the whole of the roots should be taken up bodily. It may be noted here that few, if any, ferns have tap roots. As a rule, the roots spread out more or less horizontally rather than vertically. If the plant be taken up without a lump of the soil the roots should be carefully wrapped in damp moss till it is potted. In potting, if the fern has an erect rhizome and crown, it will be well to heap most of the mould in the pot into a cone, and moisten it, before putting in the plant. Then put the fern on the top of the cone and arrange the roots round the slopes; after which, fill up the pot with fine mould nearly to the top and water well. It is a good plan to plunge the pot for a few minutes in water, nearly as deep as the pot is high; for thus the soil. becomes thoroughly wet, and as it settles in drying it packs itself closely round the roots without crushing them. I have already directed how to pot a plant with a superterrestrial creeping rhizome; and the same course is to be followed with an underground one, except that, after the rhizomes are arranged and pegged down, the pot has to be filled up with mould, instead of dead leaves, \&c. The best material in which to plant ordinary bush ferns is the mould formed by the utter decay of a large tree-stump. This is often to be met with in the bush, forming a mound, and is well worth the trouble of carrying it home. It is a good plan, in potting a fern brought from the bush, to cut away most of the fronds. This prevents the strength of the plant being exhausted, in the effort to keep the fronds alive, before the roots have got a proper hold of the soil, so as to draw nourishment from it; and when they have done so, fresh fronds will be produced. This is particularly worth attention if the plant has to be carried far before being potted. In that case, cut away the fronds at once, as soon as it is taken up. The best time for bringing ferns from the bush is at the end of autumn, or beginning of winter: for though very few of our New Zealand ones die down in winter, as the English ones do, they grow but little at that season, (in fact, mostly merely remain stationary), and therefore do not draw upon the roots for support, to any great extent. The greater amount of rain, too, during winter, affords more nourishment to the fronds and assists the roots to take hold of the soil; so that, when spring comes, the plant is in a healthy state and prepared to put forth its foliage rapidly. It is also well to shift your ferns into larger pots at the same season, but this may be done at any time; and should be so, if the roots are beginning to come through the bottom of the pot; for if such a growth is allowed to proceed to any extent it becomes difficult to take the plant out of its old pot without injuring these 
roots. Pots to contain ferns should always be carefully cleaned inside; and earthenware ones should be soaked in water just before being used, as unless this is done, the dry pot sucks the moisture from the ball of earth and dries up the roots.

Another great mistake that people make is in respect of watering ferns. They think that if they give the plants a little water every day they are doing all that is necessary. The effect is that they just keep the top surface of the soil moist while all below is quite dry: and as the roots of the fern, not being able to spread laterally, are forced to descend towards the bottom of the pot, their soft furry ends are in contact with the dry earth and sides of the pot, and so the plant dies for want of water, while the surface of the mould in the pot is quite wet; since the upper and older portion of the roots seems to lose the power of imbibing moisture. Besides this, when the earth becomes dry it contracts, and leaves a space between it and the side of the pot; so that the water runs down without really wetting the earth. This is particularly the case with the ordinary porous flower-pots, the evaporation from the surface of which, in dry weather, is enormous. I have almost discontinued using such pots; and grow my-ferns in zinc pots, as there is no evaporation from these and the plants do not require more than a quarter the water that they would do in porous-ware pots. My pots, too, instead of a hole in the bottom, have the bottom made as a loose disc of zinc, resting on an edge turned in, in the same way as cake-tins are made. This greatly facilitates the shifting of the plants into larger pots; as by pressing the loose bottom upwards, the whole ball of earth comes out in an unbroken lump, instead of being shaken to pieces by turning the pot upside down and knocking its edge to loosen the earth. In fact, the earth can at any time be thus taken out, to see if the roots have reached the bottom of the pot, so as to necessitate removal to a larger pot; and if they have not done so, the whole can be dropped back into the pot again. In the old style of pots, one had to wait till the roots began to come through the hole at the bottom; and if this was not noticed directly it occurred, the roots were very liable to get injured, in dragging them back through the hole, preparatory to repotting the plant. It is of the utmost importance not to injure the roots of a fern. I have seen an ignorant gardener tear off the roots that were growing through the hole in the bottom of the pot; a proceeding which would stop the plant's growth for, at least, six months. Pots to hold swamp ferns have their bottoms soldered in, and some small holes punched two or three inches below the top of the pot. The earth, up to the level of these, is kept thoroughly saturated with water; and thus the natural conditions of the fern's growth are fulfilled. Zinc pots, too, have the further greater advantages of lightness and not being liable to break. Glazed earthenware pots are also good and are more presentable for being brought into a sitting room occasionally, but they are heavy, and liable to break with a blow or fall. Where earthenware pots are used, one has to choose between keeping them standing in water, in which case the mould within 
them is apt to get sour, or running the risk of their getting too dry. It may be taken as a rule, however, that the best way to water a fern is to stand the pot in water, nearly its own depth, till the earth in the pot is thoroughly soaked, and then let the surplus moisture drain away, repeating the dose only when the plant absolutely requires it. Zinc pots facilitate this. But though this care is necessary in watering the roots of a fern, the atmosphere around them can as a rule hardly be kept too moist. By this, I do not mean that the plants themselves are to be syringed so much as that the floor and walls of the fernery should be kept thoroughly damp. Whether a syringe or a watering-pot be used, the rose of it ought to be fine enough to discharge the water as mere misty spray; and the water should be quite as warm as the atmosphere surrounding the ferns. To water ferns with cold water on a hot day chills them very injuriously. Some of the most beautiful exotic ferns, as for instance the gold and silver Gymnograms, must have only their roots watered; watering the foliage rots it. Some of our New Zealand ferns grow right down to the edge of the boiling water at our hot springs, sometimes in earth from which steam and sulphur vapour issues at every pore, and these will be the better for having warm water applied to their roots. What most ferns want is an atmosphere so highly saturated with moisture that it will condense on their fronds like dew. Then they are in their glory. This shows the absurdity of trying to grow our bush ferns in a room; for such an atmosphere as I have described would cause the furniture to fall to pieces and everything else to become blue-mouldy. It is only those which naturally grow in more exposed situations that will stand being carried into a room, and it is best not to keep even these there for more than a few days at a time, as they require pure air and soon get sickly indoors, particularly if exposed to the fumes of gas.

Another mistake that people make is in applying dirty water or liquid manure to ferns. Only perfectly clean water-rain-water where possible-should ever be applied to them. Manure in any form is fatal. This cannot be too carefully borne in mind. Hanging baskets are very pretty things in which to grow ferns; but these again are not suitable for rooms, as the watering necessary to keep the plants in health would cause a permanent pool of water on the floor beneath. They do well, however, in a fernery or greenhouse where the dripping from the basket helps to keep the general atmosphere moist. Such baskets are made in various ways; but, perhaps, the best are those of china or glass, in imitation of sticks laid across and across. A thickness of moss is laid on the bottom and round the sides to confine the mould in which the ferns. are planted, and the sorts selected are usually those which have long narrow fronds, which will droop over the sides and hang down so as to hide, or partially hide, the basket. Some of the ferns which have their fronds terminating in long tails, which put forth roots and young plants at their ends, are particularly suited to this kind of culture; but we have only one such in New Zealand (Asplenium flabellifolium), and it 
is not only scarce in most places, but its foliage is inconspicuous. Asplenium flaccidum and Lomaria fluviatilis are probably our best ferns for the purpose, but they are both rather coarse. Squares of cork bark are also a good deal used to grow ferns upon at home. The bark is covered with a layer of moss a good deal larger every way than itself. Mould, with the fern planted in it, is then placed on the moss, the edges of which are turned over so as to cover the mould, and the whole is secured to the cork by fine copper wires tied across and across and passed round copper tacks driven into the edges of the cork, which can then be hung up basket fashion or suspended against a wall. Of course where people can afford it, proper ferneries are the best places in which to grow these plants, and these may be either glazed or unglazed, according to the means of the owners and the class of ferns which they are to contain. In the case of glazed ferneries or greenhouses, it is well to have the means of shading the plants, by means of blinds, in hot weather. Rather coarse open canvas is best, as the object is not so much to darken the house as to divide the sun's rays and prevent scorching. Some people use two blinds of more or less open texture according to the brightness of the weather. A very cheap and yet effective fernery, however, may be constructed with walls of closely packed manuka-scrub, secured to a wooden framework, and a roof of similar scrub, left sufficiently open to admit a ınoderate amount of light. Most gardens contain some shady corner not suited for flowers, but which if sheltered from wind will suit ferns well; and by the display of a little taste in the arrangement of some old roots, stumps and branches of trees, and lumps of stone, covering a heap of earth and mould, a rockery may be formed in which ferns will grow well, and be much admired. Few Colonial houses have room enough inside them for fern stands, with bell glasses over them, to contain delicate ferns; or better still, Wardian cases. These last are zinc-lined boxes, three or four feet long by eighteen inches wide and six or eight inches deep, standing on legs about three feet high. Above this is a cover of the same size and about twelve to fifteen inches high, with its top and sides glazed. Sometimes this cover is made to lift bodily off, and sometimes so that part of it will open to get at the plants. In this, delicate ferns like the Todeas and Hymenophylla may be grown, and will not need watering for many months together.

I have for many years grown these delicate ferns out of doors by means of a similar contrivance, as follows:- -Get a zinc-lined packing case, such as drapery goods are imported in; take away the top boards on opposite sides with the corresponding zinc lining, and roof it with glass so arranged as to be capable of removal at a minute's notice to give your plants the benefit of rain. It is well to arrange the glass so that its bottom edges rest on a ledge within the zinc, and about half an inch below what has been left as the top edge of the two opposite sides of the case; as the ends are to be left standing up, and connected by a crossbar, against which the upper edge of the 
glass leans. Put your case nicely level and standing on some bricks under the shade of trees, in a sheltered part of your garden. Then put four bricks at the bottom of the case, inside, to support the boards on which your pots of ferns are to stand, and keep the space under these boards well supplied with water. If the lining of your case is watertight, you will scarcely ever need to renew the water as the rain will keep up an ample supply; in fact, in very wet weather you will have to take away part of the water. The object of letting the bottom edge of the glass go down inside the case is that, if you are not at hand to uncover your ferns during rain, the water will run down into the case instead of being wasted outside. The water in the bottom of the case supplies by its evaporation the very cool and moist atmosphere that ferns love; in fact, the conditions are exactly like those of a damp part of a New Zealand forest, and our most delicate ferns will thrive to perfection. By having several such cases, placed in rather sunnier or shadier situations, you can put the several plants in the greater or less light which they seem to prefer, and the whole contrivance costs but a few shillings and so is within the reach of every one. The great thing for most ferns, as I have already said, is a moist atmosphere. On a hot sunny day, the thermometer in my greenhouse often registers $140^{\circ}$; yet many of our New Zealand and English ferns sustain no injury, because the atmosphere is kept thoroughly moist, by reason of the trays of water in which the pots stand and evening syringeing. In describing the various ferns, I shall mention the kind of places in which they grow and how they are likely to succeed best under cultivation. It is very interesting to grow ferns from their spores, and our lovely little Gymnogramma leptophylla, being an annual, can only be grown in this way and is well worth the trouble. Fill a pot full of sandy mould, and wet it thoroughly, then scatter your spores on the surface and cover the pot with a piece of glass. Do not disturb the mould by watering it, but moisten it by standing the pot in water at longer or shorter intervals, according to the dryness or moisture of the weather. In a longer or shorter time the prothalli will appear, but at first will be scarcely discernible; and when the young ferns have grown a little, so as to have proper roots, you may begin to water them gently. When well grown, you can transplant them into separate pots; but do not be in too great a hurry to do this.

Another good way of growing ferns from spores is as follows :- Get a soft brick, if a little dirty all the better, and stand it in water nearly as deep as itself. Sow your fern spores on top of it and leave it till the young fronds appear. You will of course have to add fresh water occasionally. When the fronds have grown a little, sprinkle a thin coating of fine mould among them and add more from time to time as the plants increase in size. You may also water them lightly, and when large enough prick them out and afterwards pot them.

I have mentioned the cresting of ferns. Crested plants are always more or less 
barren. In fact, it seems as if the increased foliage was developed at the expense of the spore-producing properties of the plant. It has lately been discovered, however, that as the sterility increases, a capability of reproduction in some other way is developed. In some cases, the crowns part to an abnormal extent; and in others the ferns become capable of being grown from pieces of the cresting itself, and are being largely propagated in this manner.

The fern-grower's greatest troubles are insect pests. Slugs and snails are very destructive to ferns, particularly to some kinds which seem to attract them greatly. For instance, it is difficult to grow Asplenium Colensoi; for if there is a slug anywhere near the plant it is sure to find it out and devour the young fronds and buds. They are great pests in outdoor ferneries and in glazed cases. If one finds its way into the latter, it will often do much mischief before its presence is detected. Beetles, crickets, and wood-lice are also very troublesome. The last have a trick of getting down into the crowns, during the winter and early spring, and gnawing the young buds, with the result that when the fronds expand they are imperfect or mis-shapen. All the above conceal themselves during the day but come out and commit their depredations by night. They are therefore most easily found and caught by candlelight. Pieces of apple, turnip, carrot, or even potatoes, hollowed out and laid among the plants make good traps for these insects, but are apt to attract rats and mice, which will do mischief by burrowing among and into the pots. Thrips, small narrow insects like lice, white when young, but grey or black afterwards, are very destructive. They are only about a tenth of an inch long, or less, and the first indication of their presence is that the fronds turn grey or brown, from all the surface being eaten away or poisoned, for it seems impossible that such tiny things can eat such large surfaces. Syringeing with warm water is the best remedy. Scale insects both black and white are also destructive. A solution of soft soap, two ounces to a gallon of water, is the best remedy for these. Fumigation with tobacco is also good for them, as well as for green fly in greenhouses; but it must not be done too much or too often, as it is apt to injure the young fronds; and the same may be said of sulphur-vapour for some ferns. An old gardener, writing of insect pests, remarks, "once caught, various ways of destroying them will naturally suggest themselves."

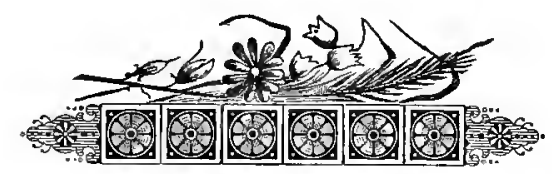




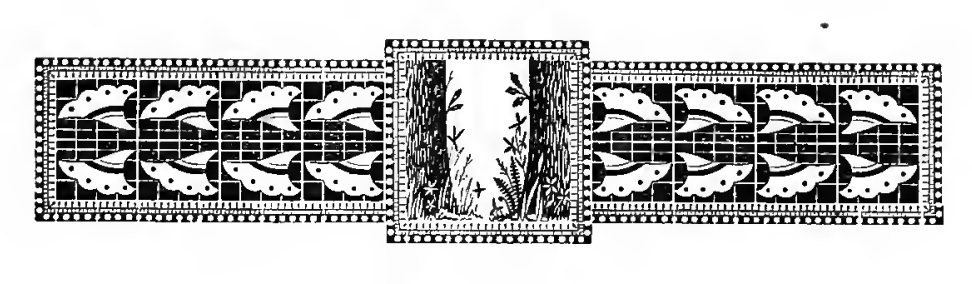

\section{DESCRIPTIONS OF N.Z. FERNS.}

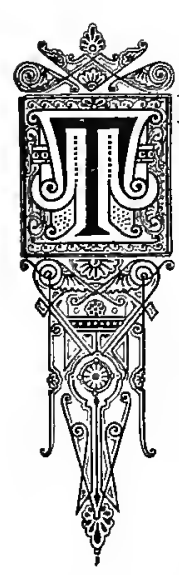

HE FOLLOWING are the ferns which have been reported as occurring in New Zealand, arranged according to their botanical classification. A guide to the pronunciation of each name is given, it being borne in mind that where two vowels come together they are to be sounded separately. Thus in trichomanoides the $\mathrm{o}$ and $\mathrm{i}$ are distinct from each other, and not a diphthong, as in void :-

\section{SUB-ORDER GLEICHENIACEAE.}

Characterised by dorsal sori of from two to ten capsules, which open vertically, and are surrounded by a broad transverse complete ring. Rhizomes mostly creeping. Stipes often dichotomous. Fronds rigid: generally large and dichotomously branched: frequently bearing axillary buds. Vernation circinate.

Two sub-genera of the genus Gleichenia are represented in New Zealand, vizEugleichenia and Mertensia. Gleichenia (so called in compliment to the German botanist, Von Gleichen) has sori consisting of few sessile capsules, situated on a lower exterior veinlet. The pinnæ are deeply pinnatifid. Fronds generally dichotomously divided, and often proliferous from the axils of the forks. Rhizome creeping. In Eugleichenia the sori are solitary at the point of a veinlet, and base of a lobe. Lobes of pinnæ small and sub-orbicular. It includes the following ferns.

\section{GLEICHENIA CIRCINATA. (Glike-ne-a sir-sin-a-ta.)}

PLATE II. No. 2.

This fern has a slender dark brown creeping rhizome with many small scales. The stipes is dark brown or black, slender and erect; and varies from a few inches to two feet or more in height : it is generally glossy and rigid, but when closely examined is seen to be furnished with numerous small scales, particularly when young. At its top two rachides or costæ, for they may be called either, branch out horizontally in 
opposite directions; and these, after producing about two pairs of pinnules, fork horizontally, about at right angles to each other. These secondary pinnæ have an oblong or slightly tapering general form, and produce a number of long pinnules, branching out right and left at right angles to them, with a similar long terminal pinnule. These pinnules are cut into numerous small rounded lobes, arranged alternately, and lying flat, or only slightly hollow below. The undersurface is often nearly white, and the sori grow in small groups of not more than four in the middle of the lobes, the edges of which curl over slightly as the sori develope. The ends of the secondary pinnæ and pinnules droop downwards so that the whole frond bears the same position in reference to the stipes, that the head of an umbrella bears to its stick. I mention this particularly, because it looks otherwise in the plate, owing to that being drawn from a pressed specimen. There is usually a bud in the fork at the top of the stipes, and this, later on, produces an upper stipes and crown. There are similar buds in the forks from which the secondary pinnæspring, and these afterwards produce a short continuation of the main pinna, and another pair of secondary pinnæ, and sometimes a third length is similarly produced beyond these, and a third crown above the second one, giving the whole frond a rather complex appearance. The fern is most plentiful in the north of the Colony, where it seems to grow everywhere among the manuka scrub and is said to spring up directly bush is cleared, but it occurs more sparingly throughout the Colony, down to Otago. If taken up in the late autumn or winter season, it is easily cultivated by arranging the rhizomes on about an inch and a half of leaf mould, pegging them down and then covering them with another inch or so of mould. The peculiar growth of the fern always attracts the notice of strangers; and it only needs a moderate amount of shade and protection from wind. It is however very difficult to move in summer. It grows also in Australia, Tasmania, New Caledonia and Malacca. The northern Maoris call it "Matua rarauhe." Mr. Colenso's "Gleichenia patens" is a more proliferous form, found near the Wairakei hot springs and at Wanganui. It is often three to four feet high, and sometimes eight or even ten feet and has very few sori and capsules. It is more membranous in its texture than the ordinary plant and dies down with frost.

\section{GLEICHENIA DICARPA. (Glike-ne-a di-car-pa.) \\ " SWAMP FERN." " RARAUhe TARANAKI" OF ThE MAORIS. \\ PLATE III. No. 1.}

This fern grows among the sphagnum moss in swamps, and in its general growth is similar to the G. circinata but taller. The secondary pinnæ, however, fork again ; and the growths from all the buds assume the character of fresh fronds, with stipes and all complete, and as the pinnules of the whole interlock for mutual support, a very 
curious and handsome mass of foliage is the result. The rhizome is creeping and woolly, with small scales; and the stipes woolly when young, but afterwards shining brown, with very few scales. Costæ also woolly when young. The lobes of the pinnules fold right over, so as to cover the sori, and thus the pinnules appear very narrow. I am not at all sure that this fern is not merely a more developed form of the preceding one. Besides the above, there are several varieties. One of them formerly called "Gleichenia circinata var. B hecistophylla" is more chaffy and woolly, and has more drooping foliage. It is said to occur in fern land in the north, but I could not get any certain information as to its doing so, though it might grow in wet scrubland. It seems a connecting link. Another, "G dicarpa var. B Alpina," is a smaller, stouter more compact and more woolly form, which, as its name implies, is found in swamps at high levels. A third form, which occurs near Wanganui, is very coarse, with dense reddish brown wool all over the stipes and under surface of the frond. It is also more compact. A fourth small form, which occurs only in very wet places, has merely one pair of pinnæ branching right and left on top of the stipes, but not forking at all. The pinnules are of extreme length, fully twice as large as ordinary. A bud at the top of the stipes produces a second stipes and pair of pinnæ; and from this there sometimes arises a third; but there is no further lateral growth. Another form known as "variety Mendelii" is cultivated in England, and differs only from the ordinary one in having pinnules of much greater length. I do not know whether it was found in New Zealand or elsewhere, but think it worth naming. The frond in the plate shews the secondary growth from two axils. Gleichenia dicarpa is easily cultivated. Cut out a mass of the sphagnum moss containing it, in the winter season, and place it in a zinc pot with a watertight bottom, keeping it well supplied with water. It is good to have a hole or two high up the sides of the pot through which the water can escape when it reaches their level, as it is not desirable to drown the rhizomes, though the moss should be kept well wetted. The plant will bear both sun and wind, so is a good one for outdoor growth, but will wither down for a time with winter frosts and produce fresh fronds in spring. In the swamps on the North side of Cook's Straits, at Mangaroa near Wellington, and around Ruapehu, I have seen large tracts covered with this fern, exposed to the fiercest gales, and growing luxuriantly. It is found as far South as Otago, and occurs also in Australia, Tasmania, New Caledonia, the Isle of Pines and Malay Islands. Mr. Colenso's "Gleichenia punctulata" is more branched or divided. Its underside is pale blue stippled with fawn-coloured dots, and it has short dark red hairs in clusters. It has been found near the hot springs in Great Barrier Island and on the West Coast of the Middle Island.

\section{SUB-GENUS MERTENSIA.}

In Mertensia the sori occur near the middle, or at a forking, of veinlets; the 
ultimate pinnæ are pectinate, that is, are divided into deep segments or lobes like the teeth of a comb. The segments are long, linear or oblong. The stipes is forked, or from development of axillary bud, proliferous and farther pinnated : pinnæ very long and pinnated, and pinnules deeply pinnatifid.

\section{GLEICHENIA (MERTENSIA) DICHOTOMA. (Glike-ne-a di-kot-om-a).}

\section{PLATE IV. No. I.}

Rhizome creeping and slightly scaly. Stipes erect, smooth, and of a light brown colour. At its top, rachides branch out right and left at an angle of about forty-five degrees, so as to be about at right angles with each other. These often send off a pinna on their outer sides, and shortly afterwards fork into ultimate pinnæ. These rachides are brown, and slightly scaly and woolly, particularly towards the forks. The pinnæ are lanceolate, and cut nearly to their costæ, into long narrow taper pinnules or segments, the edges of which are entire and bend slightly over toward the sori, thus making them seem narrower still. The colour is pale bluish green belort; and darker green above. The sori are numerous, consisting of largish groups of capsules (sometimes ten in a group), and are quite exposed. There are buds in the axils, from which farther growths can arise under favourable circumstances. This fern only occurs in the hot-spring country, where it grows in the steam of the boiling springs, and in ground too hot to be comfortably handled. I gathered it on a steep face beside, and amid the steam of, the White Terrace, and saw it a short distance farther off, by the boiling mud flat, on a hill side which was burnt red with the volcanic heat, and from which steam and sulphur vapour were issuing at every pore. These plants were of course destroyed by the Eruption of June ioth, i 886 . The frond from which the plate is drawn was gathered beside the great geyser at Wairakei. This fern would need to be grown on top of a stove; but could thus probably be cultivated. The only difficulty would be to get it conveyed thither. This fern grows throughout the tropical and sub-tropical regions of both hemispheres and in the Pacific islands as far North as Japan.

GLEICHENIA (MERTENSIA) CUNNINGHAMII. (Glike-ne-a Cun-ning-ham-i-i).

THE N.Z. "UMBRELLA FERN."

PLATE VII. Nos. 3 and 3 a.

Is only found in New Zealand. It has a rather stout creeping rhizome more or less scaly. The stipes is slender, hard and erect, and varies from black to very light brown. It is slightly scaly, and much so towards the top. At the top it forks almost horizontally right and left, and these branches immediately fork again and their 
branches again; so that in a perfect frond there are sixteen pinnæ radiating horizontally from the stipes and drooping over like the ribs of an umbrella. There are sometimes rudimentary pinnules between the top of the stipes and the next fork, but the regular ones begin at the latter. The pinnules are very long and narrow, pectinately arranged and extending nearly to the costæ of the pinnæ. Their colour is pale (sometimes silver grey) below, and dark green above, and their edges entire. They are also sometimes scaly or hairy below. The costæ are darkish brown, and scaly or furry below. There is a densely-scaly bud in the fork on the top of the stipes; and from this a second short stipes arises, bearing a second crown. A third often arises above this; and in one instance I found a frond with five crowns, one above another. Each crown is, of course, smaller than the one below it, and the whole frond presents a curious and beautiful appearance. The sori are very small, and consist of few exposed capsules; never more than six, and often single; and the margin of the pinnule curves over slightly as a protection to them, though they are close to the costæ. This fern is usually only found in bush and on the tops of high ridges, though I have seen it growing on level ground in several places near Ruapehu, and in one case it occurs close to sea-level and in open ground near Auckland. It occurs all over the colony, and becomes scaly or hairy below at high levels.

Though there is apparently no reason why this fern should not thrive well in cultivation, yet it appears to be one of the most difficult to grow. I have had many plants of it, but never succeeded in saving one of them. In some cases where I have taken up a young plant bodily with a large lump of soil in which it grew, it has lingered on for a time, only to die at last, and the same ill fortune has befallen other fern growers. In one instance a little plant thus struggled on for three years, only to die at last. The only case, which I have actually seen, of one of these plants being successfully shifted, was where no particular care was taken. A gentleman, who had no idea that the fern was difficult to move, brought a plant from the West Coast of the Middle Island to Wanganui. He seems to have taken no special care in digging it up, or in protecting it on its journey; and on reaching home he put it in the ground in a sheltered corner, on the shady side of his house, where it has grown well for some years. A fern collector in Auckland is said to have succeeded in moving the fern by sinking a box of mould in the ground beside a plant, and training rhizomes into it, cutting them off from the parent plant when they had got fully established and were producing fronds; but I did not see any of the plants that had been thus moved. It is, however, a very likely way in which to transplant the fern, and is well worth trying. I have seen plants at Christchurch and Dunedin that had been grown from spores, and were thriving well, and this appears the most likely way in which to succeed with this fern. Beyond the slight differences in colour and scaliness which I have noted, there seem to be no variations. 
GLEICHENIA (MERTENSIA) FLABELLATA. (Glike-ne-a fla-bel-la-ta.)

\author{
THE "FAN FERN."
}

PLATE VIII. No. 1.

This fern grows in a similar manner to Gleichenia Cunninghamii, but is taller, and has usually a greater number of crowns. The pinnæ however grow erect instead of horizontally, are lanceolate in form and only spread out into fans, so that the whole plant presents the appearance of several pairs of fans one above the other, instead of that of several umbrella frames. The pinnules are very long, narrow, and tapering, with entire edges for the greater part of their length, but shallowly toothed towards their tips. The sori are very numerous and are arranged in a single row on each side of the midribs of the pinnules. They usually consist of four capsules each. The rhizomes are scaleless or nearly so, as are also the stipites, rachides, and costæ, but there are sometimes a few hairs on the under side of the pinnules, which are green on both surfaces. This fern has only been found from Auckland northwards, and is not likely to be met with elsewhere. I have never heard of its being cultivated, though whether this arises from any difficulty in growing it, or from its not occurring within reach of growers, I cannot say. Those who have the opportunity should try to grow it, as established plants would be readily saleable in distant parts of the Colony, as well as in England and elsewhere. It occurs in Australia, Tasmania, and New Caledonia. Mr. Colenso's "Gleichenia littoralis" is either a variety or closely allied. From his description it is smaller and apparently has only one crown. Looks like young G flabellata. Has been found at Whangaruru Bay, Great Barrier Island, and the Thames, in bush near the sea coast.

\title{
SUB-ORDER POLYPODIACE $\&$. (Pol-ly-po-di-a-ce-æ.)
}

The characteristics of this are the plants having the sori dorsal or marginal, subglobose, of many capsules, with or without involucres, usually pedicellated (i.e., arranged round a central stalk or receptacle) more or less completely surrounded with a jointed vertical and elastic ring, and bursting transversely. It contains many tribes, of which a considerable number are represented in the colony, as may be seen by the table.

\section{TRIBE CYATHEACEÆ. (Si-a-the-a-ce-æ.)}

Named from "cyathus," a cup. This tribe has the sori dorsal, globose, often at or near the forking of a vein : capsules numerous, often very compactly arranged, sessile or stalked, generally on an elevated receptacle, often mixed with hairs, usually obovate, with a broad vertical or sub-oblique elastic ring. Involucres (wanting in Alsophila) placed beneath the sorus, but curving upwards all round, so as to completely 
envelop the sorus while young, and look like a ball : afterwards opening above, so as to expose the ripe capsules, and allow the spores to escape as the capsules burst. Generally arborescent.

\section{GENUS CYATHEA. (Si-a-the-a.)}

Sori on a vein, or in forking of a vein. Receptacles elevated, globose, or elongated. Involucre inferior (i.e., beneath the sorus) globose at first, afterwards bursting at the top, and opening into a cup (whence the name) with an even or irregular margin. Fronds simple, pinnate, or decompoundly pinnate. Arborescent. We have three generally recognised species of this genus in the colony, viz.-C. medullaris, C. Cunninghamii, and C. dealbata, and another, C. Milnei in the Kermadec islands; but as I shall show, some authorities consider that more ought to be reckoned; as they regard the varieties of form, etc., as sufficient to justify separation into distinct species.

\section{CYATHEA MEDULLARIS. (Si-a-the-a me-dul-la-ris.) \\ "BLACK TREE FERN." "MAMAKU" OR "PITAU" OF THE MAORIS.}

PLATE IX., No. 3; and PLATE XXIX., No 1.

This is the largest of our tree ferns, often attaining a height of sixty feet and occasionally far more. It also occurs in Victoria. The caudex is rather slenderlooking in proportion to the plant, particularly in tall examples. These however have generally a large conical base of hard, matted or felted, root-fibres, which is sometimes three feet or more in diameter at the surface of the ground. The Maoris split this fibrous cone into slabs two or three inches thick, which they use for lining their potato pits, and for walls of their whare-punis, as rats have a dislike to gnawing through it. The fern may be at once distinguished from all the other tree-ferns by the caudex being covered with flattened or slightly hollowed scars, where the bases of old fronds have broken clean off, and by its black colour. It is also generally more or less covered with black scales or hairs between the scars. In tall plants, the old fronds break off almost as soon as they wither, but in smaller ones, say ten feet to twenty feet high, in sheltered situations, they often hang round the caudex for several years, before they become detached; in fact, they then appear to be gradually pushed off by the growth of the aerial root-fibres, which, however, are few in number considering the size of the fern. The fronds vary greatly in size, being not more than six feet long in tall plants, while in smaller ones they often attain a length of fifteen feet to twenty feet. This does not appear to depend on shelter, as one often sees plants with these large fronds in open situations, or on lawns in gardens, for which culture this plant seems the best suited of any of the N.Z. tree ferns. The stipites are longer, in proportion to the fronds, than those of the other tree-ferns, being longest in young plants. They are black on 
the under side, but on the upper one the black gradually shades into yellowish brown. The rachis and costæ are yellowish brown above, and on the underside shade gradually from black to the same brown as the upper one. When they first appear, the stipes, rachis, and costæ are densely clothed with long, narrow, sharp-pointed, black scales, but these soon disappear, with the exception of a few at the base of the stipes, the places from which they have become detached being marked by little pointed tubercles, which make the whole framework of the frond feel rough and harsh. The fronds are broadly lanceolate, the widest part being usually above the centre, and of a bright green below, and rather darker green above. They are tri-pinnate, the primary pinnæ being long and narrow, the lower ones having rather long stalks, and the middle and upper ones being almost stalkless. The secondary pinnæ are shortly stalked, and cut right down to their costæ into sub-falcate pinnules, of which the length is about three times the breadth. The lower pinnules are stalked, which makes the frond tri-pinnate instead of merely bi-pinnate, and the rest broadly sessile; the edges at first being either entire, or only very slightly indented into rounded lobes; but the indentations deepen, and the edges curl over, as the sori develop. The sori are so numerous as almost to cover the under surface of the pinnules, and are of a globular form. They open at the top so as to form a cup, disclosing the sporecapsules crowded together on an upright club-shaped receptacle, and surrounded by an incomplete ring. Surfaces of pinnules quite smooth and shining. This fern is found throughout the North Island, as well as in the adjacent and Chatham Islands, but is scarce, or wanting, all down the East side of the Middle Island, though it crops up again in Stewart's Island. It does not seem to ascend to so high an altitude above sea-level as some of the other plants of its class. The pith is called "pitau" by the Maoris, and is very sweet but slimy. This sliminess, however, disappears when it is sliced thin, and steamed for a long time in a Maori "hangi" (cooking-pit), after which the slices are threaded on a string and hung up to dry, when they taste very much like American dried apples, and form wholesome food. As the pinna on the plate had to be so reduced, the character of the lobing could not be shewn on it and therefore an enlarged pinnule is drawn below it. Mr. Colenso describes what appears to be a variety of this fern, under the name of "Cyathea polyneuron." It occurs in Hawke's Bay Provincial District, and is distinguished by a stouter caudex, densely covered with long black hairs, hair or wool on the veins and veinlets, and very stout stipes which, as well as the rachis, is marked with a light-coloured stripe along each side. They are also densely covered with long silky brown scales, and an undergrowth of plush-like blackish brown hairs. The costæ and costules are also hairy and woolly, and the under surface of the pinnules thickly covered with silky light brown scales sprinkled with long dark brown hairs. These differences may arise from the plant growing in an exposed place, on limestone soil, as I have noticed the light stripes on 
such soils elsewhere. It is likely that other varieties of this fern occur in other places as "Cyathea Milnei" of the Kermadec Islands appears only to differ in having the pinnules broader in proportion to their length, and their being toothed instead of lobed, and this towards the tips only, and its having smaller sori.

\section{CYATHEA CUNNINGHAMII. (Si-a-the-a Cun-ning-ham-e-i.)}

PLATE IX., Nos. 1 and 2.

So called after Mr. Cunningham, the naturalist who accompanied Captain Cook, and who first described the fern, which is confined to New Zealand. There are certainly two, if not three, distinct plants called by this name in different parts of the Colony, and as Mr. Cunningham was in various parts and his description would apply to either plant, it is impossible to say with certainty which one he really meant. I will therefore describe them separately. First, there is the usual form found near Auckland, and all over that portion of the Colony, and which I think is the true plant. This has a slender caudex not exceeding twenty feet high and scarcely if at all thicker than a man's forearm, and may be distinguished at once by the number of stipites and rachides of old fronds hanging round it, below the crown. These are slender, black or nearly so in colour, and in withering, shrivel and become bent and twisted in all directions, so that they intertwine into a network. The living fronds are from six to nine feet long, broadly lanceolate and pointed. Stipes short, dark brown or black, tubercled, hairy, scaly below, and velvety above. Rachis and costæ brown, slightly velvety and hairy below, with a few long narrow scales at the sides, and very velvety above. Pinnæ long and narrow, stalked. Secondary pinnæ shortly stalked. Pinnules narrow in proportion to their length, and very deeply cut into rounded lobes which curl over. Texture thin yet harsh. The lower pinnules are stalked, but the rest broadly sessile. Both surfaces hairless. Sori brown, usually one to each lobe. In some plants the pinnules are not lobed but are narrowed for the greater portion of their length, and then widen out into tooth-like or sub-falcate lobes. Enlarged pinnules of both forms are shewn on the plate. Both forms sometimes occur on the same plant and even on the same frond. The Wellington plant has a much stouter caudex, and the old stipites and rachides hanging below the crown are light brown and straight. The fronds are shorter. The pinnæ are broader in proportion to their length and often narrow towards the ends so as to terminate in a sort of tail. The pinnules are cut into tooth-like or sub-falcate lobes, and are soft in texture. An enlarged pinnule is shewn on the plate. In other respects the plants correspond, yet it seems to me that the latter one approximates far more closely to Hemitelia Smithii than to the Auckland plant. In fact, till the two are carefully compared it and Hemitelia Smithii may be mistaken for each other. Neither form occurs at Nelson, but one, 
though I do not know which. is reported from Westland. The latter form is plentiful near Dunedin, where it is regarded as a form of Hemitelia Smithii. There is also there a form of it which exactly resembles C. medullaris, with rather slenderer stipes and rachis than usual, but with white scales instead of black, apparently a connecting link. All forms of this fern can be easily cultivated, but require more shade and shelter than C. medullaris.

\section{CYATHEA DEALBATA. (Si-a-the-a de-al-ba-ta). the "Siller tree-fern." MaOri NAME, "ponga."}

PLATE X., No. 2; and PLATE XXIX., No. 3.

This plant may generally be at once identified by the white undersurface of the fronds, though this is occasionally wanting. The caudex is often forty to fifty feet high, stout, and covered all over with the light brown ends of old stipites, which stand out at an angle to a length of about six or eight inches, and retain their place till they are buried among the aerial root-fibres. The fronds are occasionally ten or twelve feet long in young plants and sheltered situations, but are mush shorter in crowns that rise above the general vegetation in a forest. Stipes short and only moderately stout, usually white below and green above. Rachis and costæ the same, but getting gradually darker towards the top of the frond, where the latter are often almost black on their upper surface. When they first appear in spring, the stipes rachis and costæ are covered with dense brown scales which give the young fronds a dirty and unattractive appearance; but these soon drop off and only leave a slight roughness in their place. Towards the upper part of the frond, however, the upper surface of the rachis and costæ is often covered with a yellowish down, which is easily rubbed off. Frond broadly lanceolate, and often narrowing to a longish point. Pinnæ shortly stalked, and often narrowed into a sort of point towards the end. Secondary pinnæ also shortly stalked, and very generally terminating in long points. Pinnules broadly sessile throughout, or only the very bottom ones narrowly so, or partially stalked, i.e., cut down to the mid-rib on one side, while still broadly sessile on the other. Edges entire or only very faintly indented, and curving over as sori develop, as shown in enlarged pinnule. Colour generally silvery white below (whence the name "dealbata," whitened), and dull green above. There are no hairs. The sori are small and nearly black, but so thin that they soon burst, and show the yellow capsules intermixed with the hairs of the receptacle which is club-shaped. This fern occurs as far south as Canterbury and Westland, but beyond that it seems absent, or nearly so. It is also reported from Penang and Lord Howe's Island. This fern is a favourite one with the Maoris, who prefer its fronds to any others to spread on the floors of their huts for bedding. This is no doubt partly owing to their thin texture, and partly to the 
absence of hairs; but they are always careful to lay the white side downwards, lest they should be annoyed by the spores blowing about as the capsules burst. They also used it when they wanted to surprise an enemy in time of war. During the day they would make a track through the forest, and ınark it by laying down fronds of this fern with the white side upwards and the tips pointing in the direction in which they wanted to go. Whether there is some slight phosphorescence about these fronds is uncertain, but a track thus marked is distinctly traceable on the darkest night; and thus the natives could make their way through the bush, and attack the enemy's pa in the grey dawn of morning. I have often marked a trail through the bush in the same way and have found it very easy to retrace. This fern is very good to cultivate, and its silvery under surface makes it rather an attractive one for the purpose. What appears to be a variety of this fern has been called by Mr. Colenso "Cyathea tricolor." The points of difference are its rachides, being yellow above and furry below with some red scars or blotches, the bluer tint of the under-surface of the fronds, its dwarf compact form and more drooping habit of growth. It occurs on spurs of the Ruahine mountains about Norsewood and Dannevirke.

\section{GENUS HEMITELIA. (He-mit-e-le-a.)}

So called from a Greek word signifying half-finished. This genus has the sori globose, dorsal on a vein or veinlet. Receptacle elevated. Involucre a scale situated beneath the sorus, and varying in size and texture, often indistinct and often deciduous, whence the name. Arborescent. Fronds ample, pinnate or decompound. Our New Zealand Hemitelia Smithii belongs to the sub-genus "Amphicosmia," which is distinguished by having the veins all free.

\section{HEMITELIA SMITHII. (He-mit-e-lea Smith-e-i.) \\ THE "SOFT TREE FERN."}

PLATE IX., Nos. 4 and 5.

So named in compliment to Mr. Smith, of the Royal Gardens, at Kew. Was called "Cyathea Smithii" in Dr. Hooker's New Zealand flora, and elsewhere, and is confined to New Zealand. There are either two distinct ferns called by this name, or two very distinct forms of one plant. The one, which is common from Wellington to Taranaki, as well as on the West Coast of the Middle Island and near Dunedin, has a moderately stout caudex, rising to a height of thirty feet or more with a clean fibrous exterior not disfigured by bases of old stipites. The light brown straight stipites and rachides of old fronds, however, hang around it in large numbers just below the crown. The fronds are seldom, if ever, more than five feet long, and broadly lanceolate. Stipes short and, as well as the rachis, light brown, smooth, or only slightly tubercled below, with a few scattered scales on the sides; and lighter, and slightly woolly or 
hairy above. Pinnæ long and rather crowded together. Secondary pinnæ broad in proportion to their length, and cut down nearly to the costæ, into pointed pinnules or segments, the lowest of which are stalked, and the rest broadly sessile. The edges are almost entire, or only very slightly indented into tooth-like or sub-falcate lobes, towards their points. There are a few small hairs on the upper surface of the pinnules. Colour bright green above, blueish green below. The sori are few in number, and very neatly arranged in two rows on either side of the midrib of the pinnule, but mostly towards its base, as shown in enlarged pinnule. They are small, and almost black; so that they show very distinctly on the light under-surface of the pinnæ. The texture is very thin and soft. When first growing up in spring, the young fronds are very conspicuous, from their fresh bright green colour, which at once distinguishes them from the dull brown ones of Cyathea dealbata, with which they generally grow; for though the stipes and rachis are at this time clothed with bremn hairs or scales, there are not enough of them to hide the green. This plant usually occurs in rather light bush, and generally towards the bottoms of gullies. It is easy to cultivate: and very effective from its bright soft green, which is particularly bright in young plants. Near Dunedin, examples of this fern with branched caudices are common. One on Mount Cargill has sixteen branches. The scaly form called at Wellington Cyathea Cunninghamii is also common in Otago. The other form, which prevails in the north of the Colony, but which I met with also in the Mangarthero Valley, north of Cook's Strait, has a shorter stouter caudex, and much larger and blunter fronds, sometimes nine feet long. The stipes and rachis are much rougher and hairier below, but like those of the other plant above, and they are far darker in colour. When they first appear, they are thickly covered with very long chocolate-coloured hairs, and though most of these soon drop off, a good many still remain at the bases of the stipites. The pinnules are cut right down to the costæ, the lowest being stalked and the rest sessile. Their texture is harsher, as well as far darker, and their edges are deeply indented into rounded lobes, which become toothlike towards the points, and bend over towards the sori. See enlarged pinnule. The sori are far more numerous, often extending over more than two-thirds of the length of the pinnules; and when the cup-like involucres open, the receptacle is seen to be very distinctly stalked or narrowed below. This plant seems to grow only in heavy bush, and occurs on flat land at Mangawhero. The fern found by Mr. Colenso between Norsewood and Dannevirke, and which he named "Hemitelia stellulata," appears to to be this last plant (at all events, the Mangawhero form of it), with a paler undersurface, stippled with white dots.

\section{GENUS ALSOPHILA. (Al-soph-il-a.)}

From alsos, a forest, and phileo, I love. Has the sori globose and dorsal on 
a vein or in fork of a vein. Receptacle mostly elevated, and frequently hairy. Generally has the arborescent habit of Cyathea and Hemitelia, but is destitute of involucres. Veins simple or forked, free. Our only recognised species is

\section{ALSOPHILA COLENSOI. (Al-soph-il-a Co-len-so-i.) \\ PLATE III., No. 4.}

So called after its discoverer, the Rev. W. Colenso, of Napier, and confined to New Zealand. The fern usually thus called is only found near the snow line, in the North Island, but occurs at lower levels in the Middle one, descending to 1500 feet in Otago. Though classed as a tree-fern, it is not truly so, as the caudex lies on the ground, with only its end, which is much thinner and softer than the rest, turned upwards. As this end thickens (it apparently never exceeds one and a half inches thick), and hardens, it lies down, and produces long hard wiry root-fibres, which point towards the crown, instead of away from it, as the root-fibres of ordinary caudices do. These root-fibres enter the ground, and hold the caudex fast. If, in travelling along, the end of the caudex encounters a fallen log or other obstacle, it climbs over it, and descends to the ground again on the other side to continue its course. Thus the crown of the plant is often some distance from the original root. It is said that the caudex occasionally becomes erect; but though I have seen thousands of acres of the fern, I never could find a plant with a naturally erect caudex, and have tried for years to compel a cultivated specimen to produce one. Of course when climbing over an obstacle, or when jammed in an angle of rock, a caudex may be forced to ascend for a time, but this is under unnatural conditions. Mr. G. M. Thomson, of Dunedin, told me he had once seen a caudex growing erect; but the plant was situated in a dense low mass of bramble, and had had to struggle upwards for light and air, so was not a fair example. The Rev. W. Colenso assures me that the ferns found by him on the Ruahine mountains had caudices sometimes $7 \mathrm{ft}$. high; and Professor Kirk and Mr. T. F. Cheeseman also mention haring seen plants with caudices. I conclude, therefore, that either there are actually, in different places, two ferns with similar foliage called by the one name; or else the one plant has curiously reverted to the arborescent type in certain localities. The crown of the plant consists of but few fronds, which are never more than $2 \mathrm{ft}$. to $3 \mathrm{ft}$. long, and very broadly lanceolate. The stipes is very short, almost wanting, in fact; and in the North Island plant both it and the rachis and the costæ of the pinnæ are of a light brown colour, smooth, with a few darker brown scales below, and slightly velvety above. The pinnæ are arranged alternately, and are so close together as to overlap considerably. The lower ones are very short, and so deflexed as to lie flat against the face of the stipes, and hide it. The pinnules are numerous, and deeply cut into broad sub-falcate lobes, with their edges entire or nearly so. The colour is a soft bright yellowish green, turning 
reddish brown with sharp frost; and the veins, which are zigzag and two or three times forked, are very inconspicuous. In the Middle Island plant the stipes and rachis are generally clothed with dark reddish brown tomentum, rather thickly studded with scales of a very light brown colour. The lower pinnæ are longer and less deflexed; and the stipes is also far longer, and densely clothed with long whitish scales towards its base. Both forms are slightly hairy (with white hairs) on their surfaces, but the southern one is the more so, and has longer hairs. Both are easily cultivated, and very handsome plants; but from their creeping habit are rather unsuited to pot-culture. The determination of the caudex to grow horizontally will make it burst out the side of an earthenware pot and force a zinc one out of shape, but the plant will do well in an outdoor rockery. This fern only grows naturally in the open ground above the forest level; and often extends over large areas where there is not even a shrub to afford it shelter. It is never found more than a few yards within the bush. No doubt its peculiar mode of growth has been necessitated by its having to withstand the fierce winds which sweep over the situations in which it is found; but the habit has become so fixed that the plant adheres to it even when placed under more favourable conditions. Possibly plants raised from spores might change their habit, but $\dot{I}$ do not know any one who has so raised any, as comparatively few fern-collectors have ever seen the plant, much less cultivated it. It surprised me much to find, when some plants were brought from the back of the Canterbury Province a year or two ago, that several of the best authorities on ferns in Wellington thought it was a new one, though I had had plants of it from the Ruahine range in cultivation for a lengthened period. It has been met with at Ruapehu, Mount Egmont, and the Tararua and Ruahine ranges in the North Island, and probably occurs at high levels elsewhere. In the Middle Island it has been found at Nelson, Westland, Canterbury, Otago, and Southland, and as it descends to a lower level in that part has attracted more notice. I have often wondered that it does not occur at lower levels still in both Islands, as I have grown it so long myself and have seen it in ferneries and gardens, not many feet above the sea, both at Dunedin and Christchurch. Possibly it requires a cold misty atmosphere to develop its spores, and the only chance of cultivating it is to bring down young plants, as is done regularly every autunn by florists down South. I have a dried specimen for which I am indebted to Mr. A. C. Purdie of Dunedin, of a variety discovered a few years ago on Mount Cargill, near that city, in which all the pinnæ fork from their very bases, one half being deflexed and the other ascending. Those on one side of the rachis thus cross each other all the way up the frond, giving it a most curious appearance. Young plants showing this peculiarity would be well worth cultivating if they can be obtained, as they probably can, the plant originally observed being apparently merely overgrown by brambles at the present time. 


\section{GENUS DICKSONIA. (Dik-so-ni-a.)}

So called in compliment to a Scotch botanist named Dickson. This has the sori at the point of a vein near the margin of the frond. Involucres placed beneath the sorus, sub-globose, coriaceous or membranacenus, opening across the top, so as to appear more or less distinctly two-valved. About half the plants of this genus are arborescent, with large decompound coriaceous fronds, the others have creeping rhizomes. Our Dicksonias all belong to the sub-genus "Balantium," in which the involucre opens across, but the valves do not fall right back. The outer half of the involucre is formed of the reflexed margin of the frond.

DICKSONIA SQUARROSA. (Dik-so-ni-a Squar-ro-sa.)

\section{"SlENDER TREE-FERn." " ROUGH TREe-Fern." MAORI NAMES, "WEki" AND "TUAKURA."}

PLATE X., No. 6; and PLATE XXV., No. 6.

This is probably the commonest of our Dicksonias, as it is found all over the Colony, at all events at fairly low levels and also at the Chatham Islands, but not elsewhere. It usually occurs in groups or groves, and mostly on low ridges or other fairly dry places, and is often found in pretty exposed situations. The caudex attains a height of twenty to thirty feet, and is very slender, seldom thicker than a man's forearm. It may at once be known by the numerous black bases of old stipites, about nine inches long, which remain all over the caudex and stand nearly straight up against it. The crown consists of only a few broadly-lanceolate fronds, seldom more than six feet long, which arch over rather gracefully, probably through having the stipes rather longer in proportion than that of most tree-ferns. When young the stipes, rachis and costæ are densely covered with long black or brown hairs, and a few of these almost always remain permanently towards the base of the stipes. The rest of them, however, drop off and leave behind them prickly tubercles, which make the whole under-surface of the frond feel very rough, whence the specific name, which means "scaly." The stipes, rachis, and costæ are all very dark brown below, and rather lighter and velvety above, but it may be noted that the velvety portion does not extend over the whole width, but is confined to a depression between higher edges. The frond is widest about the middle, and does not decrease in width downwards so much as that of many ferns, but as the lower pinnæ are much deflexed the frond looks narrower below than it would do if they stood straight out. In fact, in young plants the lower pinnæ hardly decrease in length at all. Both primary and secondary pinnæ are very shortly stalked and the former are narrow in proportion to their length, numerous, rather crowded together, and often are lengthened out into a long point. The lower pinnules are stalked and the rest sessile; and they are deeply cut into lobes, each of which contains one sorus, over which it bends to such an extent as to form half of the 
involucre. The whole under-surface of the frond, in fact, becomes a mass of fructification; and as the texture of the pinnules is very harsh, and the sori large and hard, it is not easy to press this fern satisfactorily. The sori, of course, split open across the top when ripe. This fern is very easily cultivated, and its carelessness in the matter of shade, and its harsh texture, which renders it little liable to injury from wind, make it a very suitable one for a garden, particularly if planted among low shrubs, which will prevent the soil about the roots from becoming too dry. When it overtops the shrubs it looks very well. The Maoris used this fern a good deal in building their huts; the walls being often composed entirely of it, as it lasts well in the ground. For more important buildings, such as whare-punis and runanga-houses, they dress off the outer surface, so as to show the bases of the stipites and the internal structure of the caudex, which is very handsomely marked with grey and black. They then set these up at regular intervals around the interior of the house to act as columns, and fill in the intervals with panelling of fern stalks or toi reeds (sometimes blackened spirally with a hot ember), secured by interlacing bands of New Zealand flax or kiekie, or the white split hearts of the kiekie runners; the whole having a very pretty appearance. Fences, too, are often built of these caudices to enclose yards or portions of pas; and very pretty vases may be turned out of them by anyone who is a good hand at the lathe. Mr. Colenso's "D. gracilis" has a lighter crown, with narrower foliage; and lateral shoots with crowns grow out of the caudex all the way up it, but I can see no good specific difference. It is common.

\section{DICKSONIA FIBROSA. (Dik-so-ne-a Fi-bro-sa.)}

"WOOLLY TREE FERN"; MAORI NAMES "WEKIPONGA" AND "TAKOTE." PLATE X., No. 5, and XXV., No. 1.

This is the handsomest of all our tree ferns, from the great number of fronds which form its crown, and the manner in which they rise in tiers one above the other; and in its typical form it is confined to New Zealand. The caudex seldom, if ever, attains the height of $25 \mathrm{ft}$., but is extremely stout in appearance, owing to the mass of matted fibrous aerial roots which envelops the actual caudex and which is often $\mathrm{I} 5 \mathrm{in}$. to $18 \mathrm{in}$. in diameter, and occasionally even more. Curiously enough, it is often larger in diameter above than below, particularly in plants not exceeding $6 \mathrm{ft}$. or so in height; which shows to how great an extent this fern absorbs nourishment from the atmosphere by means of its aerial roots. The fronds simply droop down as they wither, and thus the old ones of several seasons are usually to be seen hanging around the caudex and protecting it from sun and wind; while the sub-erect growth of the live ones makes them act as a funnel to convey rain down to the caudex, which then absorbs it, owing to its soft fibrous character. The stipes is short, and, like the rachis and costæ, is thickly covered with soft downy hairs, which are of a light brown below 
and rather darker brown above. The fronds are long ovate-lanceolate, sometimes rather bluntly so at the ends. They are from $6 \mathrm{ft}$. to 1 oft. long, and far narrower in proportion to their length than those of $D$. squarrosa. The lower pinnæ also taper away very much, and are comparatively little deflexed. The pinnæ are rather crowded, long and narrow, and often lengthened into a sort of tail. The secondary pinnæ are short and tapering, particularly towards their tips. Their costæ are very slender, and the pinnules small and set well apart from each other. A considerable proportion of the pinnules are distinctly stalked (quite half of them on the lower pinnæ), and the rest only narrowly sessile. The edges are indented into rounded lobes, but not so deeply so as those of D. squarrosa, and these lobes curl over, so as partially to cover the sori, which are small, and one to each lobe. The texture is harsh.

The sori burst open transversely, and, like those of D. squarrosa, the pinnæ are soriferous to their very tips. The colour of the pinnules is usually dark green above and lighter green below; but these colours get lighter in exposed situations. A stunted form found at high levels, particularly in the Middle Island, has the fronds of a bright golden brown colour, which they retain in cultivation in exposed situations, where they stand better than the ordinary kind, which only grows in damp places and usually in high bush. If the bush is cleared, so as to let sun and wind get to the soil and caudices, the ferns soon dwindle and die; yet young plants grow well without much shelter; and when so grown are hardy. This is, therefore, one of the best ferns to plant in a garden, as sun and wind will not hurt the crown, provided the caudex is a little sheltered at the bottom; but it will not be wise to remove the dead fronds. I have seen it stated that the Maoris cut slabs out of the caudices of this fern, and used them for building purposes; but I doubt it, as the fibrous portion is too soft for such a purpose; at any rate, in the central parts of the Colony. It was, no doubt, the fibrous part of Cyathea Medullaris which was so used. This fern is also called "D. intermedia," and was classed by Dr. Hooker as "D. antarctica"; but the Tasmanian fern so called has a harsher caudex, broader fronds, and larger sori. The Chatham Island fern, however, approximates so closely to $\mathrm{D}$. antarctica as to make it very doubtful whether Dr. Hooker was not right. From a statement made by Mr. J. B. Armstrong, of Christchurch, in the "Transactions of the New Zealand Institute," Vol. XIII., p. 360, the Tasmanian plant appears to grow far more rapidly. He says it "is the fastest-growing tree-fern we have yet experimented with. Plants only seven and a-half years old from spores have made trunks varying from three inches to ten inches high, and three inches to four inches through. It is, therefore, likely that the rapidity of the growth of the tree-fern stems has been very much under-estimated by most writers on ferns." I, on the other hand, have plants of D. fibrosa at least twenty years old which show no sign of a caudex, and my only example which has one had it when I brought home the fern fully fifteen years ago, and it has not increased in 
height six inches in that time. At present its caudex is about nine inches high by five inches in diameter, and the plant must be nearly or quite fifty years old. It grows in a shady sheltered place, and produces fronds fully five feet long; so that its slow growth is not the result of unfavourable conditions. The fern is found apparently throughout the Colony, but becomes scarce towards the southern end, though, curiously enough, it ascends to a higher level than $\mathrm{D}$. squarrosa. Mr. Colenso's "Dicksonia Sparmanniana" appears to be a variety with the fronds narrowing downwards, and with larger sori than ordinary; and his "D. microcarpa" is a smaller plant, with softer narrower foliage and lighter green colour. The tips of its fronds also turn upwards. Both occur in forests near Dannevirke.

\section{DICKSONIA LANATA. (Dik-so-ne-a La-na-ta.)}

PLATE XI., Nos. 1, 1a, and 1b.

Also called "Dicksonia Lævis," and peculiar to New Zealand. Was formerly classed in the early editions of the synopsis as a variety of D. antarctica just as the last one was, but their specific distinctness is recognised in the appendix, though I am not sure whether altogether justly, as there seem to be two distinct plants included under this name. The first and commonest occurs at pretty high levels throughout the Colony, and as I for many years knew of no other I was puzzled to understand its being called "lanata," woolly, unless on the lucus a non lucendo principle, as the plant is very far less hairy than either of the other Dicksonias, and usually almost destitute of hair. The plant has creeping rhizomes as thick as a man's wrist or forearm, from which at intervals crowns of a few fronds, seldom more than four or five, arise, and it seems never to produce any caudex at all, even when it is so old that its fronds are from $4 \mathrm{ft}$. to $5 \mathrm{ft}$. high. It covers large spaces of ground in patches, and there are few or no solitary plants scattered through the forest. In fact, the patches are often a mile or more apart, even in the localities where the fern occurs. These rhizomes are almost destitute of enveloping scales or root-fibres. The stipes is very long, generally longer than the frond itself, of a light-brown colour, and though it is dotted with short whitish or reddish hairs when it first grows up, these generally all soon drop off, excepting a few at the very base, and leave the stem clean and glossy. If, however, the bush is cleared and the plants exposed, the hairs will remain. They thus seem a provision of nature to protect the stipes from cold, like the fur of animals. The frond is very broadly lanceolate or rhomboid, nearly as broad as long, and the lower pinnæ diminish but little in length, though they are sometimes considerably deflexed. The rachis and costæ are smooth below, and shade gradually from the brown of the stipes to a dull dark green. Their upper side has a narrow velvety stripe of a darker green colour along the centre; and there is often a little down at the bases of the costæ. The pinnæ are few in number, far apart, tapering, and 
usually arranged in opposite or sub-opposite pairs. Both they and the secondary pinnæ are very shortly stalked. The latter taper from the middle to the point, and are divided into pinnules, a few of which, and only towards the base of the frond, are stalked or narrowly sessile, and the rest broadly sessile. In barren fronds, the edges of the pinnules are rather deeply toothed; but, strangely enough, fertile fronds at first have them entire or only slightly toothed towards the tips. As the sori develop, however, the entire edges become deeply cut into rounded lobes, which curl over slightly. The sori are very large, and as they do not open widely they are very obviously two-valved. Only a very few fronds are fertile, and these generally only over the lower portions of the pinnæ towards the base of the frond. The texture of the frond is very harsh; colour, olive green above, bluish green below; veins very conspicuous. This plant is found on level rather moist land in high bush, and grows extremely well in cultivation, provided it has a fair amount of shade and shelter.

The other plant is only certainly found in a few places well to the North of Auckland, and apparently only beside rivers. It has a stout clean caudex from four to six feet high (Mr. Kirk says he has seen it ten feet), and is said to have fronds like the other, but forming a crown. The long stipes, however, which is so striking a characteristic of the plant which I have been describing, is hardly reconcilable with one's idea of a tree-fern, and hence I conclude that the plants are really different. About ten years ago, I saw in the Murimotu country, south-west of Ruapehu, a stunted tree-fern which attracted my attention from its peculiar appearance; and from its growing close to a patch of $\mathrm{D}$. lanata, I thought it might be the arborescent form and that the others might be seedlings from it. On close examination, however, I decided that it was merely a chance form of $\mathrm{D}$. fibrosa, with shorter broader fronds, thinner caudex, and larger sori than usual : and as I have since seen many large patches of D. lanata and have never found any similar tree-fern near them I feel sure that I was right, and therefore think that the northern plant is merely a similar form of D. fibrosa approximating so closely to $\mathrm{D}$. antarctica that probably it was rightly classed with that fern, though the true D. Lanata could hardly be so. In the case I have mentioned, there were no intermediate forms. The plant was a solitary one; but it is obvious that, if seedlings from it grow up near it they may present an intermediate appearance. My belief is that the plant was actually a hybrid between D. fibrosa and D. lanata, as the former was abundant close by, and the northern plants may be the same or have sprung from a similar cross. This illustrates the difficulty with which fern-collectors in the Colony have to contend. They know a fern as it occurs in a certain part of the Colony, perhaps a large part, and yet it differs in some important respect from the description given of that fern from plants grown elsewhere. Hence doubts arise, which can only be set at rest by visiting distant places and comparing notes with other collectors; and this may not always be practicable, though so far as my experience goes, I have 
always found lovers of ferns not only willing but glad to afford each other any information in their power. The botanical observers of the Colony are disgracefully few, considering the ample field and unusual facilities for the work within the reach of most settlers; and hence it is only natural that a sort of Freemasonry should arise between those who engage in the study. As I have stated, I have visited most parts of the North Island from Cook's Strait to beyond Auckland, and have travelled southwards to beyond Otago, and compared notes with other collectors, and yet am doubtful on many points; in fact, in some cases, the further information gained has only increased my doubts. Considerable changes of form sometimes occur, as plants grow and develop, and any one who has not had the opportunity of watching these, may be misled by them; while those who have had the opportunity naturally regard similar changes as possible in other cases. There is thus an ample field still open for observation in ferns alone, and it is to be regretted that those who have the best opportunities for it do not, for the most part, avail themselves of them, but regard the indigenous plants of the Colony merely as things to be destroyed as quickly as possible, though many are of great value.

TRIBE HYMENOPHYLLACEÆ. (Hi-men-o-fil-la-ce-æ.)

Generally creeping-plants, with membranous fronds and marginal or axillary sori. Involucres either two-valved or urn-shaped. Receptacle columnar or clavate, sometimes projecting as a long hair of greater or less length beyond the involucre. Capsules sessile, surrounded by a complete horizontal or oblique ribbed ring. In $\mathrm{New}$ Zealand it includes three Genera, viz.. Loxsoma, Hymenophyllum, and Trichomanes.

\section{GENUS LOXSOMA. (Lox-som-a.)}

From Greek words signifying obliquely-ringed, the capsules being so. As our New Zealand plant is the only one of the genus, its description will serve for that of the genus also.

\section{LOXSOMA CUNNINGHAMII. (Lox-som-a Cun-ning-ham-e-i.)}

PLATE XII., No. 1.

Has the rhizome creeping, and densely covered with long reddish brown hairs. Stipes long, and as well as rachis, smooth and usually of a light brown colour. Frond broadly rhomboidal and often two feet high, including the stipes; glossy dark green on the upper surface, and lighter, often bluish, or white on the under one; bi or tripinnate. Pinnæ wide apart, stalked, usually in pairs, and pointing much upward. Secondary and tertiary pinnæ also stalked, broadly rhomboidal, narrowing to lanceolate in the upper ones, and also pointing upwards. The pinnules also point much upwards, and are lanceolate and broadly sessile, their bases being continued as a wing down the sides of the costæ. They are so deeply cut as almost to justify 
the frond being called again pinnate, particularly as these farther divisions are themselves pretty deeply lobed. The sori are terminal on some of the lower lobes; but as there is usually a longer lobe than the fertile one immediately outside of it, the sori, at first sight, appear axillary; and though they are numerous, they seem confined to the lower portions and sides of the pinnules, and never occur on the terminal lobes. The involucres consist of two valves of an oval form and moderate size; but the receptacle soon protrudes far beyond them, bearing elongated oval masses of capsules, often three or four times the size of the involucres. This fern, which is a strikingly handsome one, is peculiar to New Zealand, but has only been found from about Auckland northwards. It grows in light bush or high scrub, and on hill-sides or terraces, rather than in the bottoms of gullies; and when shaken by the wind, looks particularly beautiful, owing to the different colour of its upper and under-surfaces, as they alternately show and disappear wave-like. The colour of the under-surface seems to vary with the season of the year, though it is whiter in some localities than in others. It is not difficult to grow, if the plants are procured while young; but it will not stand frost, and it spreads so rapidly as not to be well suited to pot-culture. Leaf-mould over clay, with moderate moisture, are its natural conditions. This fern is specially interesting on account of its being apparently a survivor from an extremely remote past. It is far more closely allied than any other now existing to the Palæopteris Hibernica, a fossil fern found in the Devonian rocks, and the most ancient land plant of which the remains have come down to us in a sufficiently perfect form to be capable of identification. In the same strata are found fragments of what appear to be Hymenophylla, indicating that the filmy ferns were among the earliest plants that grew on dry land, though some seaweeds seem to have preceded them.

\section{GENUS HYMENOPHYLLUM. (Hy-men-o-fil-lum.) "FIL.MY FERNS."}

From Greek hymen, a film; phyllon, a leaf. Has the sori marginal, more or less sunk in the frond or exserted, terminating a costa or vein. Involucres beneath sorus, more or less deeply two-lipped or two-valved, of nearly same texture as the frond, toothed, entire, or fringed. Receptacle elongated, usually cylindrical, inserted or exserted. Capsules mostly orbicular, depressed, attached by the centre; furnished with broad transverse ring, opening irregularly at the top. Fronds generally membranous in texture, costate, or with simple or forked veins only. This genus divides into several classes, according to peculiarities of the fronds, and this facilitates classification. First, there are plants with entire edges, one to four times pinnatifid some of which again have wings on the rachis only, while in others the wings extend down the stipes also. Of the former the following are the plants generally recognised as belonging to New Zealand and its immediate dependencies. 


\section{HYMENOPHYLLUM RARUM. (Hi-men-o-fil-lum ra-rum.)}

\section{PLATE V., No. 5.}

This fern is of a very light bluish green colour, growing in dense mats on the trunks of trees, usually on those which have astringent bark, such as hinau or tawhero, but sometimes on tree-ferns. Rhizomes black, smooth, and threadlike or wiry. The fronds vary from one inch to eight or nine inches in length, but the stipes is very long and slender in proportion to the frond itself, in fact quite hairlike. Frond, usually bipinnatifidly and deeply lobed, and oblong in form. Pinnæ numerous, and overlapping each other, the lower ones sometimes stalked. Lobes short and broad. Texture very thin. Sori terminal and covered by very large, broad, flattened involucres with entire edges and sunk in the ends of the lobes. This fern only occurs in very damp shady places, usually beside streams in the bottoms of gullies, and at all levels up to about. 3 ooo feet above the sea. The fronds hang downwards, and the only way to grow this fern is to get a piece of the stem or bark on which it is seen, and place it upright in a case, or under a bell glass, in a shady place, standing the pot in a saucer of water, to keep the atmosphere cool and moist. A widely-spread fern, extending from Japan to the Auckland Islands, and from Africa to South America, but nowhere very plentiful. Mr. Colenso's "Hymenophyllum imbricatum" is a form with very overlapping pinnæ and edges slightly wavy. It is not uncommon.

\section{HYMENOPHYLLỤM FLABELLATUM. (Hi-men-o-fil-lum fla-bel-la-tum.) PLATE XIX., No. 6.}

This fern is usually found in the same situations as the last, and often on the same tree. It, however, more frequently occurs on the roots than the trunks of trees; and is occasionally met with on rotten logs. Its rhizome is creeping, and thickly covered with light brown downy scales. It is also less densely matted than the last. Stipes and rachis black and shining. Frond oval, usually from one to two inches long, but occasionally as much as fifteen or eighteen inches. The pinnæ are stalked, and so numerous and closely set as to overlap. They are fan-shaped, whence the name, and divided into broad lobes, radiating more or less from the stalk, and generally pretty equal in length. In large fronds, however, the middle ones are often considerably elongated, and it is sometimes not easy to distinguish between them and those of long oval examples of Hymenophyllum demissum, till the rhizome is examined. The smell of dried fronds, however, is different. Sori numerous, enclosed in small oval involucres, with entire edges, sunk in the ends of the lobes, but less so than in the lastdescribed species. Texture thin. This fern is also called "Hymenophyllum nitens," on account of its shining glossy appearance. The fronds always hang downwards and it requires to be grown in the same manner as "Hymenophyllum rarum" for this reason. It also occurs in Australia and the Auckland Islands. 


\section{HYMENOPHYLLUM DEMISSUM. (Hi-men-o-fil-lum de-mis-sum.) \\ PLATE XVIII., No. 1.}

This is one of our most abundant Hymenophylla, and grows on the ground as well as on trunks of trees and fern-tree stems in all the wooded parts of the Colony. In the former case, however, the fronds are usually rather broadly triangular, while in the latter they are generally oval, and sometimes very long in proportion to their width. The rhizome is black, wiry, and creeping. Stipes of moderate length, stiff, black or dark brown, and shining. Rachis the same but narrowly winged. Costæ more widely so. Fronds, six to nine inches long, tri or quadri-pinnatifid, the pinnæ and secondary pinnæ being almost stalked and pointing upward. Pinnules more or less fan-shaped, and divided into long narrow lobes. Texture thin, colour bright green. This fern seems to care less about moisture than most of the Hymenophylla, as it is often found growing on the ground on the tops of ridges, though always in bush, as well as on treetrunks and fern-tree stems at a lower level. It is consequently an easy one to cultivate in glazed cases or under bell glasses and very effective in appearance. Leafmould, or sand mixed with rotten sawdust, or pounded rotten wood suit it well. Dried and pressed fronds smell like seaweed. There are various forms of this fern, to some of which distinct names have been given. Mr. Colenso's "Hymenophyllum erectoalatum" has the wings prolonged for a short distance down the stipes and redder sori than usual. It is a small form found near Norsewood. His "Hymenophyllum megalocarpum" is the same with remarkably large reddish sori, and involucres much wider than the lobes on which they grow. It occurs in open bush land near Norsewood and Dannevirke. A form found in the high country towards the head of the Wanganui river has the texture of the fronds, harsh and sub-coriaceous, instead of membranous, and the colour is a dark olive green; but the plant does not differ in any other important particular. The Otago form is narrower and longer in its foliage than the North Island ones. This plant in various forms extends from Java and the Philippines southward through the Polynesian Islands and New Zealand.

\section{HYMENOPHYLLUM POLYANTHOS. (Hi-men-o-fil-lum po-ly-an-thos.) PLATE XXVIII., No. 7.}

This is probably the commonest Hymenophyllum in the Colony, as it is plentiful everywhere in our forests, where it grows in dense mats on the trunks and branches of trees, as well as on rotten logs. It varies greatly in size and shape, being sometimes less than half an inch long and at others more than a foot. In small plants the fronds are usually oval or lanceolate in shape, while in large ones they become broadly triangular and often have the apex of the frond and the tips of the pinnæ narrowed into quite long tails. Sometimes they are all tail, being a foot long by only half an inch wide. The rhizomes are rather stout and usually wiry, and the stipes short, stout, 
smooth and narrowly winged towards the top. The rachis and costæ are also more broadly winged; in fact, the frond is bicr tri-pinnatifid rather than pinnate. The pinnæ and secondary pinnæ are wide and spreading, and the ultimate lobes or segments rather broad in proportion to their length, more or less membranous, and varying from light to dull olive green. The sori are numerous, terminal, sometimes apparently subaxillary, large, and enclosed in large involucres of a round or oval form, with entire edges. This fern has the peculiarity of staining the paper red or brown when drying, whence it is also called "sanguinolentum;" and when dry it has a strong odour like the old-fashioned medicine called "Gregory's mixture," which it retains for years, so that it is quite unmistakable. From the position in which it naturally grows, it shrivels up and looks dead in dry weather, but as soon as a shower comes it freshens up as green and bright as ever. From this it may be supposed that it is an easy fern to cultivate, but it is not so. The only way to succeed with it is to carry home a branch, or piece of one, on which it is growing. This placed in a glazed case or under a bell glass will last for years with occasional watering, but it must not be too much wetted or it will grow mouldy and rot. A small branch covered with this fern set upright under a glass shade is pretty, and its colour is generally brighter when so grown than when in the bush. This fern becomes hairy as one ascends to high levels, till it assumes the form called by Mr. Colenso "Hymenophyllum villosum" (Plate XIX., No. 7. No doubt, the hairiness is a protection from the cold, as the plant appears to differ in no other way. The peculiarity however seems to connect it with another class of the Hymenophylla, viz., the hairy ones; just as the partially-winged stipes connect it and Mr. Colenso's "Hymenophyllum erecto-alatum" with the following, which have their stipites winged throughout. The same gentleman's "Hymenophyllum lophocarpum" is this fern tailed, and slightly hairy. H. polyanthos occurs throughout the tropical and temperate regions of both hemispheres, but apparently not in Australia.

\section{HYMENOPHYLLUM DILATATUM. (Hi-men-o-fil-lum di-la-ta-tum.) PLATE XVI., No. 1.}

This is a very handsome fern of a dark, but bright, green colour, which grows plentifully in the damper parts of gullies, upon tree-trunks and rotten logs. It has a long, thin, wiry, creeping, black or dark brown, velvety rhizome, without scales, and spreads over considerable surfaces, though the fronds are seldom close together. The stipes is dark brown, and very narrowly winged throughout, though the wings die away almost, or quite, to nothing towards the base of the stipes. The rachis is more broadly winged, as are also the costæ. The fronds are from six inches to more than two feet in length, but vary less in width; the short ones grow erect, but the long ones are usually pendulous. They are usually tri-pinnatifid, but large ones are sometimes 
divided again, particularly towards the base. The fronds are lanceolate, and the pinnæ broadly so, and pointed upwards. The whole foliage is broad, whence the name. The ultimate lobes are long, even in proportion to their width. The sori are seldom numerous, and vary much in size. They are enclosed in involucres placed on the ends of the lobes, but rarely on the terminal ones. Sometimes they are small and oval, inserted in the ends of the lobes, and at others are large and round, wider than the lobes, and project beyond them. This fern is easy to grow, under similar treatment to that which I have recommended for Hymenophyllum demissum; but is best placed on the shady side of a case. There seem to be no verry noticeable varieties of this fern, beyond the difference in the length of the fronds. The foliage, however, is wider and more membranous in some localities than in others, particularly in the north of the Colony. It occurs in the Chatham and Auckland Islands, as well as in New Zealand, and from Java southwards. An allied form also occurs in South America.

HYMENOPHYLLUM PULCHERRIMUM. (Hi-men-o-fil-luin pul-ker-rim-um). PLATE XX., No. 8.

This, as its name implies, is regarded as the most beautiful of our Hymenophylla. The rhizome is short, stout, erect or sub-erect, and armed with stiff bristles; and the fronds are fairly numerous, springing from its sides, and first growing upwards, and then curving gracefully over. When growing, as it usually does, among moss on a log or tree-trunk, the fronds hang down, and sometimes attain a length of from eighteen inches to two feet. The stipes is rather short, and broadly winged to the very base. The frond is sometimes lanceolate and sometimes narrowly triangular, and tri or quadri-pinnatifid. The rachis and costæe are also all winged, but only narrowly so. The pinnæ and secondary pinnæ point upwards towards the apex of the frond, and the whole foliage is small and delicate. The sori are fairly numerous, small, enclosed in small very obviously two-valved involucres, with entire edges. These are placed at the ends of the lobes, into which they are usually partly sunk. In some cases, however, the greater part of the lobe is wanting, and the sorus, which, in this case, is larger than usual, appears at first sight to be axillary. Texture, membranous; colour, dark green. In the North Island this fern is only found at high levels (say, I $500 \mathrm{ft}$. and upwards to $3000 \mathrm{ft}$.) ; but in the Middle Island, particularly on the West Coast, it is more plentiful, and occurs at lower levels. It is only found in high bush or very damp places; still it is not difficult to cultivate in a glazed case if planted in leafmould and rotten wood. Beyond the slight differences in the form and length of fronds, and the foliage of different plants being a little finer or coarser, there appear to be no varieties. It is confined to New Zealand and the immediately adjacent islands, so far as at present known. 


\section{HYMENOPHYLLUM JAVANICUM. (Hi-men-o-fil-lum Ja-van-ik-um).}

PLATE XV., No. 4.

This fern was the "Hymenophyllum crispatum" of Dr. Hooker's flora, and is found in damp forests throughout the Colony at all levels up to about 3000 feet, as well as throughout India, Malaya, the Philippines and Australia. It is questionable whether it is nof really more beautiful than that last described, particularly in its more minutely-foliaged, and lighter-coloured forms from high levels. The rhizome is rather stout, smooth and creeping. Stipes and rachis erect, stiff, brown, and broadly margined with wings, which are much indented with crenulate hollows and are also very wavy, from which peculiarities the fern derives its other name of "Hymenophyllum crispatum." The fronds vary from two to eight inches long and are tripinnatifid. The pinnæ and secondary pinnæ are deeply cut into narrow lobes, the edges of which are sometimes entire or nearly so, but usually much crenulated and waved. Their texture is membranous, and the colour of the young fronds very bright green which becomes darker with age. When grown in a pot, the young fronds come up erect among the older ones which slope outwards, and the fronds grow closer together. This gives the fern very much the appearance of having a dense crown of fronds, while the difference in colour between the young and old fronds is very attractive. The sori are numerous and large, with large entire-edged involucres, placed at the ends of the lobes. This fern grows extremely well in a case, in a mixture of leaf mould and rotten sawdust; and no fernery should be without it. It is also a good fern to grow under a bell-glass indoors. The only common variations seem to be those of size, coarseness or delicacy of foliage, and darker or lighter colour, plants from higher levels being generally smaller, lighter-coloured, and more finely divided and indented than those from near the sea level. Mr. Colenso's "Hymenophyllum atrovirens" seems to be merely this plant with plane lobes, and smaller sori than usual, and to form a connecting link between it and

\section{HYMENOPHYLLUM MONTANUM. (Hi-men-o-fil-lum mon-ta-num.)}

\section{PLATE XXVIII., No. 1.}

This fern was first found near the Whakatipu Lake by Mrs. Mason who sent it to Professor Kirk, but has since been gathered at high levels in other parts of the Middle Island. In its general appearance it looks like a stiff narrow form of $\mathrm{H}$. Javanicum, with entire and uncrisped wings and foliage, or small $\mathrm{H}$. dilatatum; but a closer examination shows that it is differently divided, the pinnæ being lobed only on their upper sides. In fact all the lobes point upward and are slightly forked at their ends. The rachis, too, is bent in a zigzag fashion from pinna to pinna, the stipes winged nearly to the base, and the sori small and terminal, generally on the second lobes only. The involucres are narrow, oval, usually with deeply toothed and jagged lips, and very 
clearly two-valved; but this last characteristic is not invariable, the larger frond on plate having entire edges to its involucres, as has also a frond kindly sent me by Mrs. Mason. The former was gathered on the West Coast of the Middle Island, and curiously enough agrees generally far better with Professor Kirk's description of the fern, than that shown in his accompanying drawing, which is copied alongside of it, and which looks as if taken from a mis-shapen frond. No one seems to have grown this fern; indeed, very few collectors have ever seen it. When lately at Christchurch and Dunedin, I could only find one person who had a correct specimen. Others had merely peculiar forms of other ferns, which they had gathered thinking they might be it, and one gentleman actually classed it by mistake as a form of "Hymenophyllum Tunbridgense," in a published list of the Canterbury ferns.

The following form a second class of Hymenophylla with hairy fronds and often hairy or indented edges. They mostly occur in colder situations than the former, and the hairiness seems a protection from the cold.

\section{HYMENOPHYLLUM SCABRUM. (Hi-men-o-fil-lum sca-brum.) PLATE XVII., NO. 4.}

This fern is found only in New Zealand, and has a slender creeping rhizome, usually smooth or but slightly hairy. Stipes not winged, or only slightly so towards top; densely covered with long very dark brown or black hairs when young, as are also the rachis and costæ. Many of these hairs however fall off, leaving small tubercles in their places. Rachis winged towards the top. Frond varying from broadly triangular to oval or narrowly lanceolate in shape, and from four inches to two feet in length, the long fronds being always narrow with the pinnæ far apart; tri-pinnatifid. Primary pinnæ well apart, and very triangular in shape. Secondary ones close together, lanceolate and deeply cut into narrow lobes. Texture, membranous; colour, dark olive green. Sori large and numerous, enclosed in terminal involucres wider than the lobes, and usually with toothed lips. There are sometimes a few hairs on the surfaces. This fern may at once be recognised by its dark colour, and hairy or rough stipes. It only grows among moss on tree-trunks, or rotten logs, in the very wettest places in the bush, such as by streams in deep gullies, or on flats where water lies during great part of the year, and the air is fairly saturated with moisture. In fact, the damper the place the better and finer the plant grows. In warm but damp gullies I have found the plant almost hairless, but rough to the touch, the hairs having fallen. It will succeed in cultivation under similar conditions to the other Hymenophylla previously described, but must be put in the shadiest and dampest case, and dampest part of that, as it shrivels immediately in a dry atmosphere, though it will stand great cold. 1 have seen it stiff with ice, when all the surrounding trees were hung with icicles two or three feet long, yet it took no harm. Besides the differences of size and form, there 
is one very distinct and beautiful variety, named by $\mathrm{Mr}$. Colenso "var. hirtum "which has the hairs of a light yellowish brown, particularly when young. It is not uncommon.

HYMENOPHYLLUM SUBTILISSIMUM. (Hi-men-o-fil-lum sub-ti-lis-sim-um.) PLATE XV., No. 2.

This is one of the most lovely of our Hymenophylla, its name bespeaking it as "the most delicate." It grows in dense mats among long moss, on tree trunks, rotten logs, and particularly on stems of tree-ferns, in deep damp gullies. It has smooth creeping, slender rhizomes, and very short, stout, downy stipes. The fronds are oval, oblong or lanceolate, and vary from an inch to nearly a foot in length, being usually however about three to four inches long, and bi or tri-pinnate. The pinnæ are broad, numerous, pinnatifid, and overlap each other; the secondary ones lanceolate, and deeply cut into narrow lobes. The texture is so thinly membranous as to be almost transparent, and the colour of so yellowish a green that the fern was formerly called "æruginosum (æ-ru-gin-o-sum)," i.e., brassy. The rachis, costæ and veins are thickly studded with short bristles growing in clusters, and similar ciusters are found on both surfaces of the frond, and more plentifully round the edges. The sori are very numerous, and placed on the ends of the lobes. The involucres short, very broad, and bristly. The fronds generally hang down. This fern is found all over the Colony, certainly up to a height of 2000 feet above the sea and appears to be particularly luxuriant in Stewart's Island. It also occurs at the Chatham Islands, Chili, Chiloe, Juan Fernandez, and Tristan d'Acunha. Its fronds turn reddish brown when dry. It grows well in a case or under a bell glass, but care is required to keep the moss in which it grows wet enough and yet not saturated with moisture, lest the fern should rot. The air around it cannot be made too moist. The only varieties seem to be those arising from the different size and shape of the fronds in various localities. The fronds are occasionally forked.

\section{HYMENOPHYLLUM RUFESCENS. (Hi-men-o-fil-lum ru-fes-sens.) PLATE XV., No. 6.}

This is a small fern found growing in mats, on tree-trunks at high levels. It has slender, wiry, creeping rhizomes with few scales, and an extremely long hair-like stipes, far longer than the frond itself, though the length of the whole seldom, if ever, exceeds three inches. The stipes has a very few short scattered hairs on it, but these generally fall off. The rachis, costæ, veins, and whole surfaces of the frond are thickly dotted over with long silky hairs, which grow singly, and there are similar hairs round the margins. Some of the hairs seem deciduous. Frond rather broadly triangular, and upper part of rachis winged. The lower pinnæ are stalked and broadly triangular or rhomboidal ; the next also stalked but narrower, and the others sessile and bluntly 
lanceolate. They are twice cut into broad short lobes. The texture and colour are like that of the last fern. The sori are numerous and conspicuous, their involucres being large, extremely hairy (sometimes toothed also), and situated at the ends of the lobes. This fern was first found by my son, Mr. H. A. Field, on the Ruahine Mountains, near the source of the Oroua, in 1876 , and two years later by Mr. Hamilton, at Okarito. It has since been gathered by Professor Kirk in Stewart's Island, and by Mr. T. F. Cheeseman on the top of Te Aroha Mountain, so that it no doubt may be met with nearly throughout the Colony at high levels. It also occurs at Tristan d'Acunha. I believe that no one has tried to grow it, and its cultivation would probably be difficult for want of sufficient cold in winter. The only differences noticed in this fern are as regards size, the specimens from the South being larger than those from the North Island, but this may be accidental.

HYMENOPHYLLUM CILIATUM. (Hi-men-o-fil-lum sil-li-a-tum.)

This is one of the doubtful ferns mentioned a few pages back. It occurs all through the tropics of both Hemispheres, as well as in Australia, and is reported as having been once gathered, many years ago, by Mr. H. Travers somewhere in the Nelson Provincial District. Unfortunately the exact locality was not noted, and the plant has been sought for in vain by other collectors ever since. Moreover, Mr. Travers had botanised in other countries as well as in New Zealand, and it is known that somehow his Australian specimens got mixed with his Chatham Islands ones, and nearly caused mistake as to the plants belonging to the latter locality. It is thus doubted whether the Hymenophyllum ciliatum was gathered in New Zealand at all, but as the fern, if it occurs in Nelson, is still more likely to do so in the North Island, I have thought it best to include it. It has an erect rhizome covered with hairs or scales. Stipes about half as long as the frond itself, hairy and winged towards the top. Frond oblong or lanceolate, often narrowed towards the apex, two to six inches long and tripinnate. The rachis is broadly winged and hairy. The lower pinnæ are usually rhomboidal with a broadly winged costa, and many long lobes which are also hairy. Sori pretty numerous, at ends of lateral pinnæ only. Involucres round and swollen, sunk in the ends of the lobes, with valves opening only half way down, and very hairy. Texture membranous, colour bright green. This fern may at once be distinguished by its thick erect rhizome, and its hairy fronds, which seldom unroll completely, particulars in which it differs from all other New Zealand Hymenophylla. It was formerly cultivated in the Botanical gardens at Christchurch, but has died, so that I could get no specimen for a plate.

The next series of our Hymenophylla belong to the Sub-Genus "Leptocyomium," which is distinguished by having the edges of the foliage furnished with thorny-looking teeth, usually some distance asunder. 


\section{HYMENOPHYLLUM CHEESEMANNIl. Hi-men-o-fil-lum Cheese-man-ne-i.}

PLATE V., NO. 3.

This is probably the smallest fern in the Colony, as it seldom, if ever, exceeds half an inch in length. It has slender thread-like rhizomes, and grows in mats on the upper branches of trees. It can hardly be said to have a stipes, as the frond develops almost at once from the rhizome. The frond consists sometimes of a single broad lobe, more often of two, and occasionally of three radiating from a common centre. Their texture is membranous, and each is furnished not only with a costa, but with a stout vein extending all round the margin. The sori are very conspicuous, being wider than the lobes on whose ends they are situated, and so swollen as to be almost globular. The involucres are large enough to quite cover the sorus, and have entire edges without teeth or hairs. This fern is named after its discoverer, Mr. T. F. Cheeseman, of the Auckland Museum, who found it in the northern part of the North Island. It has since been gathered, however, as far south as Stewart's Island, as well as at intervening points; so that it is no doubt general, though its small size causes it to be overlooked, particularly as it grows among moss, and usually merely in the tops of trees, so that the only chance of finding it is by searching in freshly-felled bush, before it is burnt. It seems to grow lower down the trees as one gets farther south, and Mr. Kirk describes it as occurring on the bases of shrubs, on Ruggedy Mountain, Stewart's Island. So far as I know, no one has tried to grow it, but it would no doubt thrive in a glazed case, if a piece of a branch covered with it were placed there, and it would be worth the space it occupied, even as a curiosity. It has not been gathered outside New Zealand.

\section{HYMENOPHYLLUM TUNBRIDGENSE. (Hi-men-o-fil-lum Tun-bridg-en-se.) PLATE XIV., No. 7.}

This is the "Tunbridge fern" or "Filmy fern" of England, and like the preceding one, has thread-like creeping rhizomes, and covers the surfaces of tree-trunks, roots, and logs, with a dense mat of its fronds. It also grows on rocks in some places. Stipes rather long and wiry, dark brown, with a few short hairs. Rachis and costæ the same with longer hairs. Costæ sometimes narrowly winged above. Frond seldom exceeding two inches long, oval or oblong, bi-pinnate. Pinnæ well stalked. Secondary pinnæe well apart, stalked, and sometimes divided into two to four oblong lobes spreading out like a fan, and at others forming a lengthened pinna with several alternate lobes. Texture membranous, colour usually dark green. Sori generally classed as supra-axillary, which means that they grow near to, but not quite in the axils. When closely examined under a good magnifying glass, however, they will be seen to be really terminal, on very much shortened lobes : it being not unusual to find a barren lobe alongside and completing a pinna. The involucres are round, sunk in 
the ends of the lobes, and have their edges prickly or toothed. There are a great many forms of this fern. One known as "Cupressiforme" has larger fronds, with longer lobes than ordinary, and the pinnæ are deflexed downwards and outwards. Another called "Hymenophyllum minimum" (Plate XVI., No. 5) is altogether a smaller plant than ordinary, and has prickles on the faces of the involucres as well as on the edges. An extremely minute form of even this, with only one or two pairs of pinnæ to the frond, and these short and broad, is called by $\mathrm{Mr}$. Colenso " $\mathrm{H}$. pygmœum." It occurs on the Port Hills, between Lyttelton and Christchurch.

Another (Plate XIV., No. 8), is classed as "unilaterale " or "Wilsoni." It has its lobes so long and narrow as to be merely linear, and they are, as well as its sori, on the upper side of the pinnæ only. The involucres also are often without teeth. It only occurs at high levels, 3000 feet or more above the sea, and I only know for certain of its having been found on the Ruahine Mountains. Another, not uncommon near Wanganui, has a sort of tail of sori (sometimes as many as ten of them) arranged along both sides of the rachis, above the barren portions of the frond. Van den Bosch, the Dutch Botanist, reckons no less than fourteen different varieties, which he considers sufficiently distinct to entitle them to be classed as species, and probably all, or nearly all of them occur in New Zealand, and possibly others which he did not know, yet the two figured in Plate XIV. are the only ones which are noticed in the Synopsis, as presenting special peculiarities worthy of attention. It is interesting to find specimens of the various forms of a fern and place them in one's herbarium; but it would make the list an endless one to give separate names to them all, as there are a host of links connecting them, and scarcely any two plants, or even two fronds, are exactly alike. Hymenophyllum Tunbridgense is a favourite fern for cultivation in England, and grows well in a case, or under a bell glass, or even in a very damp shady place in a fernery. It is found all over the Colony, and indeed all over the world, from England to here.

\section{HYMENOPHYLLUM MULTIFIDUM. (Hi-men-o-fil-lum mul-tif-id-um.)}

PLATE XIX., No. 8.

This is a very beautiful fern which grows in similar positions to the last, but often in more exposed situations. I found it among moss in the crevices of the scoria rocks not far below the snow line on Ruapehu, and even on their faces; of course much stunted, but quite unmistakable, and nearly or quite as perfect in the form of its fronds as at low levels. As a rule, however, it does not occur at less than 500 feet or so above sea level, and curiously enough, when it does so, it is in deeper shade than usual. It also occurs in the islands of the Pacific. It has creeping, slender, wiry rhizomes, and its fronds usually form a dense mat. Stipes variable, but generally rather short, dark brown, and shining. Rachis smooth and slightly winged above only. Frond from 
half an inch to six or eight inches long, and varying much in form, from rhomboid to oblong or long lanceolate, tri-pinnate. Pinnæ longer or shorter according to the shape of the frond, the longest fronds hanging down on tree-trunks or fern-tree stems, and the short broad ones growing erect on roots or logs. Secondary pinnæ divided into a great number of long narrow lobes; whence the name, which means "much cleft." Texture membranous, but generally seeming harsher than that of most Hymenophylla, on account of the narrowness of the lobes ; colour, generally dark green; edges much toothed. The Southern forms are more membranous than the North Island ones. Sori large, stalked, and axillary. Involucres with entire edges, and very obviously twolipped. The only varieties seem those arising from difference of size and form, which are, no doubt, due to situation, the finest plants occurring in sheltered, and the dwarf ones in very exposed places. It will grow in a case or under a bell-glass, but not so well as most other Hymenophylla. It occurs throughout the Colony, from the North Cape to Stewart's Island, where it was found by Mr. Kirk up to fully zoooft. elevation.

\section{HYMENOPHYLLUM BIVALVE. (Hi-men-o-fil-lum bi-val-ve.)}

PLATE XVII., No. 3.

This fern is generally similar to the last, but grows longer, being sometimes $\mathrm{r} 5 \mathrm{in}$. high. It is also more triangular in the form of its frond, and has a longer stipes in proportion. The rhizome is stouter, and in the North Island it seems always to grow erect, among moss, on the ground, or on fallen logs, and not pendulous on treetrunks, but it grows on tree-trunks near Dunedin and Lyttelton. The sori, though generally small, are very numerous, and situated at the ends of the lobes, in which the oval entire-lipped involucres are sunk. The number of the sori, and their position, gives the frond a drooping habit, like that of a weeping willow, which is very attractive. This fern is seldom found below 1500 ft. elevation, but occurs from the Thames to Stewart's Island, and at the Chatham Islands. A narrow form was observed by Mr. Kirk on Stewart's Island, which seems the only variation. It grows freely under glass.

The last of our Hymenophylla is totally different from the rest and is not filmy at all. It is called

\section{HYMENOPHYLLUM MALINGII. (Hi-men-o-fil-lum Ma-ling-e-i.) PLATE VII. No. 2.}

It was so called after one of the New Zealand Company's surveyors, who first found it, and who was killed in the Wairau massacre; and it was classed by Dr. Hooker as a Trichomanes, its non-diaphanous texture seeming to preclude its inclusion among the filmy ferns, though it corresponds with them in its sori. This fern has a rough, reddish, slightly scaly rhizome which creeps among the loose bark on the decaying limbs or trunks of trees, usually on Toatoa, at high levels, and will even 
pierce the bark itself. The late Mr. Potts, of Christchurch, however, stated that he had found it on Totara and New Zealand Cedar. From its peculiar colours, it is apt to escape notice, and to be mistaken at a little distance for a lichen. Its slender stipes varies greatly in length, and is usually of a brown colour slightly sprinkled with lighter brown hairs. It has also a thick patch of scaly hairs at its base. The frond varies greatly in length, breadth, and cutting; being bi tri or quadri-pinnatifid in different specimens. It is covered, rachis and all, with dense stellate tomentum, both above and below. The colour of the upper surface varies from silvery to greenish grey and dull yellow, while the under one is reddish brown. Texture coriaceous and harsh, and dried fronds brittle. In the Synopsis it is said to be closely allied to a South American fern "Hym. sericeum," but no other seems to resemble it at all. It has been found on Ruapehu, Mt. Egmont, and the Ruahine range, in the North Island, and on the mountains of Nelson and the West Coast, as well as at Banks' Peninsula and the high hills near Dunedin, in the Middle Island, so that it may be looked for at high levels throughout the Colony. I do not know of any one having attempted to grow it, but if a branch on which it occurred were placed in a damp fernery or case, the fern would probably thrive, for though it seems usually to grow only on dry, dead wood, yet this is in situations where it is frequently enveloped in clouds or dense mists, the moisture of which is no doubt absorbed by its velvety surfaces. I have lately received two plants from Dunedin which seem doing well. This fern is peculiar to New Zealand.

\section{GENUS TRICHOMANES. (Tri-kom-an-ees.) \\ "BRISTLE FERNS."}

This genus has the sori marginal, and always at the end of a vein, and more or less sunk in the frond. Involucres urn-shaped or trumpet-shaped, and of similar texture to the frond itself. Mouth of involucres often winged or slightly two-lipped. Receptacle thread-like and elongated; often protruding a long way beyond the involucres. This accounts for the name, which means abounding in hair, as the sori are usually numerous, and the long hairs projecting from them are very conspicuous on the under-side of the fronds. The receptacle usually only bears capsules at its base within the involucre. The capsules are sessile, depressed, and surrounded by an entire broad ring, nearly transverse, and bursting vertically.

\section{TRICHOMANES RENIFORME. (Tri-kom-an-ees ren-if-or-me.) \\ THE "KIDNEY FERN." \\ PLATE II., No. 3.}

This is a very favourite fern with horticulturists, its dark yet semi-transparent green colour, and distinct veining, making it very attractive. It has long hard creeping rhizomes, about one twentieth of an inch thick, and often covers a space of 
many square yards on the ground, or climbs to a great height on tree-trunks enveloping them like ivy. The stipes is black, smooth, and wiry; usually longer than the frond, and narrowly winged above. It has no rachis, the veins spreading out in a fan-like manner and dividing and sub-dividing as they approach the edge of the frond. The frond is kidney-shaped, glossy and hairless, and generally flat, but sometimes crisped or wavy towards the margin. In barren fronds the edge is entire, but in fertile ones it is surrounded by urn-shaped involucres, from the tops of which short, stout receptacles often project to the distance of an eighth of an inch. Though this fern is more often found on ridges than in flat wet bush, yet it is not very easy to cultivate, requiring a moist atmosphere, a fair amount of light, and shelter from wind It grows best under a bell-glass, in leaf mould, or pounded rotten wood, or among moss, and will not bear having its rhizomes imbedded in earth. By attending to these points, the plant forms a handsome ornament for a room, and requires but little watering. The only variation from the normal form that I have seen occurs at Taranaki, where the fronds sometimes assume the crescent shape of a cheeseknife. Occasionally, too, but very rarely, the stipes is forked, and produces two fronds. The fern occurs throughout the Northern Island, and all down the West Coast of the Middle Island, but is rare and local in the Canterbury and Otago Provinces. It is also found in Eastern Australia, and the Chatham Islands.

\section{TRICHOMANES ARMSTRONGII. (Tri-kom-an-ees Arm-strong-e-i.) \\ PLATE V., No. 1.}

This fern is named after its discoverer, Mr. Armstrong, of Christchurch, who found it growing among moss beside a waterfall, near the head of the Waimakariri river. It has since however been found at other places in the Middle lsland, and Professor Kirk lately told me he had seen it growing in the moss hanging from the branches of trees, in very damp situations. There seems to be a very general opinion among fern-collectors that it is identical with Hymenophyllum Cheesemannii, and I confess that I incline to that opinion myself; for though in some specimens, as in that shown in the plate, the sori seem those of Trichomanes, in others, perhaps gathered from the same patch, they are as clearly those of Hymenophyllum. The toothed edge also is characteristic of the sub-genus Leptocyomium of Hymenophyllum and does not occur in any other Trichomanes. The principal difference appears to be that the thick nerve surrounding Hymenophyllum Cheesemannii is absent in $T$. Armstrongii, but this seems not to be an invariable feature of the former, being found sometimes only on one side of the frond and not on the other, and occasionally absent altogether. If the plants are not identical, T. Armstrongii is a connecting link between the two genera. It has thread-like rhizomes, short stipes, frond consisting of not more than from one to four broad lobes with toothed edges, and terminal 
sori. In some cases, as in the plate, the soriferous lobes are shorter than the barren ones. The plant will only be found in very moist situations, and so far as I know, no one has cultivated it, its small size making it only worth growing as a curiosity. It seems confined to New Zealand.

\section{TRICHOMANES LYALLII. (Tri-kom-an-ees Ly-al-le-i.) PLATE V., No. 4.}

This delicate little fern forms another connecting link between the Genera Hymenophyllum and Trichomanes, and was at one time classed in the former. In fact, it is very doubtful whether the old one was not the correct classification, as the sori seem unmistakably those of Hymenophyllum, and the texture, hairiness, and general character are similar to those of $\mathrm{H}$. subtilissimum. It seems only to grow on the caudices of tree-ferns in very damp situations, but is found in such places nearly from end to end of the Colony, particularly on the Western side. It has a very slender creeping rhizome, and a long hair-like stipes. The frond can hardly be said to have a rachis, as it divides and sub-divides into a number of long narrow lobes, which spread out in a fan-like manner. They are extremely thin, and furnished with veins along their centres, and bristle-like teeth and hairs along their edges. Colour, golden brown or yellowish green. The sori are flat and round, inserted in the ends of the lobes. Involucres with hairy edges. I do not know of any one but myself having cultivated this fern, but a short length of a tree-fern caudex, covered with it, would form a pretty object under a bell glass, if frequently wetted.

\section{TRICHOMANES HUMILE. (Tri-kom-an-ees hu-mil-e.) PLATE V., No. 8.}

This little fern seems only to grow on steep faces of hard gravel, in very shady damp bush. It has wiry thread-like creeping rhizomes, and spreads over considerable patches, which it covers with its pendent fronds. The stipites are thin, smooth, wiry, and winged towards the top. The frond has no distinct rachis, but forks and forks again, often very irregularly, dividing ultimately into long narrow lobes, with naked surfaces and entire edges. The texture is membranous, with a vein along the centre of each lobe. The sori are few in number, and usually axillary or sub-axillary, and sunk in short lobes. The receptacle usually projects, as a long hair, from the end of the vaseshaped involucre. I have never known this fern cultivated; but it could no doubt be so, by cutting out a block of the gravel on which it was growing, and building it into the wall on the shady side of a fernery. It is sparingly found throughout the North Island; but is very rare in the Middle one, being only found in its northern half. It occurs in Java and the Pacific Islands; and a closely allied form is found in tropical America, South and West Africa, India, and the islands between these and Australia. 


\section{TRICHOMANES VENOSUM. (Tri-kom-an-ees ve-no-sum.)}

PLATE XIV., No. 4.

This little fern usually forms dense masses on the caudices of tree-ferns, and rootstocks of semi-arborescent ones; but occasionally grows on rotten logs, among moss. Its delicate, light, translucent green colour renders it very attractive. The rhizome is slender, wiry, and creeping. The stipes thread-like, rather long, shining, and dark coloured. Rachis the same, but lighter towards the top. The frond is long, generally narrow, and bi-pinnate. The pinnæ, particularly the upper ones, are divided into lobes, which are much elongated, and have their edges slightly indented. The sori are sub-axillary; involucres urn-shaped; and the receptacles protrude, like hairs of greater or less length. The texture is very thin, the surfaces naked, and the colour usually yellowish green. A short length of a fern-tree stem, well covered with this fern, is a very pretty object, and will last for many years standing upright under a bell glass, if it be only watered occasionally; the best mode of watering being to uncover it, and put it out of doors during rain. It is found throughout the Colony, as well as in Australia, Tasmania, and the Chatham Islands.

\section{TRICHOMANES VENUSTULUM. (Tri-kom-an-ees ve-nus-tu-luin.) \\ PLATE XV., No. 1.}

This little fern is generally regarded as merely a form of the last; but is considered by Mr. Colenso, and others, to be entitled to specific distinction. It grows in the same manner, and often on the same tree-fern : in fact, their rhizomes often intermix, and this gave rise to the idea that the mass was all one plant, with fronds of different shapes. T. venustulum has its pinnæ short, oval, and distinctly and regularly lobed; and is altogether a smaller plant than the other. It is also of a lighter colour, and even thinner texture. It can be similarly cultivated; and probably is found elsewhere than in New Zealand, though it has only been differentiated here, and that doubtfully.

\section{TRICHOMANES COLENSOI. (Tri-kom-an-ees Co-len-so-i.) PLATE XXII., No. 3.}

This is one of the most beautiful of the New Zealand ferns, but is by no means common, and is confined to the Colony. Its rhizome is thin and wiry, with a few short hairs, and creeps considerably, so that the plant forms considerable patches where it occurs. The stipes is generally about half as long as the frond, hair-like, black, glossy and naked. The fronds are dark green, oblong or lanceolate, and bi or tri-pinnatifid, with stalked pinnæ. The pinnules are long lanceolate, but sometimes more or less deeply lobed, and occasionally even fan-shaped in large specimens. They are also stalked. Surfaces naked. The sori are usually sub-axillary and stalked 
but sometimes are more or less inserted in the side of a lobe near its base. The involucres are vase-shaped, and the hair-like receptacle seldom protrudes far.

This fern only grows among moss, beside waterfalls or in dark moist places by the sides of streams, and thus probably often escapes notice, as its hair-like appearance renders it somewhat difficult to distinguish, particularly if the moss is covered with stalked spore capsules. It was first described by Mr. Colenso, who found it at Waikare-moana, in the Uriwera country, but it occurs at various places in the Wellington and Taranaki Provinces, as well as in Nelson, Westland, Canterbury, Otago, and Southland, and if sought for will probably be found in many other localities. It is an easy fern to cultivate, requiring little attention, beyond a moist atmosphere favourable to the growth of the moss among which it creeps. I have had a plant of it growing in a cool place for fully fifteen years, and it has not yet got beyond the bounds of a six-inch pot, so that a patch of a yard or more in diameter must be very aged.

\section{TRICHOMANES RIGIDUM VAR. STRICTUM. (Tri-kom-an-es rid-gid-um.} Var. strict-um.)

PLATE XXVIII., No. 3.

This plant has a stout erect rhizome, from which a number of fronds arise, and grow nearly straight upwards. The roots are long and very wiry. The stipes is usually about half as long as the frond, brown, stiff, smooth, and polished, with occasionally a few short hairs at its base, and a narrow wing towards the top. Rachis is usually narrowly winged towards the top. The frond is oblong, long and narrow, rather stiff, of a yellowish green colour; and usually tripinnatifid. Pinnæ stalked, ascending, lanceolate, and divided into long narrow lobes, which also point upwards. Surfaces naked. The sori are few in number, stalked, and axillary. Involucres urn-shaped with protruding hair-like receptacles. This fern sometimes grows on the ground among moss, and sometimes on rotten logs, usually in rather open bush, and occasionally among low shrubs, in the edges of clearings. It is however by no means common, though it has been gathered in most parts of the North Island, and down the Western side of the South one, as far as the Sounds and at various levels up to 3000 feet above the sea, but only here and there. For some time I was doubtful whether it was properly classed, along with the next fern, as merely a variety of rigidum, and I notice that $\mathrm{Mr}$. Thompson still considers it a distinct fern. Professor Kirk, however, kindly gave me a specimen from the Hunua, near Auckland, which is quadripinnate and has the dark colour and broadly lanceolate shape of $T$. elongatum, indicating that the two are really only forms of one plant. This fern was called "T. strictum" by Dr. Hooker, and "T. leptophyllum" and "T. Cunninghamii" by other authorities. It is only known to occur in New Zealand. It is a handsome fern, often nine inches to one foot high, but it is difficult to cultivate, as when the roots 
are once loosened from the material in which they are growing they seem to have great difficulty in taking a fresh hold of new soil. It is quite necessary, therefore, to cut off all the fronds and leave the plant to put out new ones as the roots get established.

TRICHOMANES RIGIDUM VAR. ELONGATUM. (Tri-kom-an-ees rid-gid-um, var. e-lon-ga-tum.)

PLATE XVI., No. 2.

This was the "Trichomanes elongatum" of Dr. Hooker, and in its growth resembles the last, but occurs more plentifully and in different situations. It has a stout erect rhizome, from which a few fronds (seldom more than six) arise. Roots very long and wiry. The stipes is stout, erect, wiry, smooth and often narrowly winged above, and slightly hairy at the base. The rachis usually winged. The frond varies from three to six inches in length, is broadly triangular, lanceolate or ovate, and tri or quadri-pinnate or pinnatifid. The pinnæ are numerous, often overlapping each other, stalked, and vary from triangular to oval. The pinnules are cut into short, broad lobes with entire or slightly-toothed edges. The colour is dark olive green, and the texture sub-coriaceous. The surfaces are slightly rough and hairy, and are very generally overgrown with moss, which spoils the appearance of the plant. I know no other fern which moss attacks in the same way. The sori are very numerous, and situated in the axils of the pinnæ and pinnules. The involucres urn-shaped, with the hairlike receptacles often protruding considerably.

This fern is found in heavy bush, but usually in dry, sandy soil, under overhanging ledges. I have got it from various localities, up to 3000 feet above sea-level, but always on steep faces in dry soil and a moist atmosphere. It is not easy to move, as the sandy soil breaks away from the roots, which do not readily become re-established. It is a very beautiful fern when clean, and greatly resembles the much prized "Killarney fern" "(T. radicans)" in appearance, except that the latter has a creeping rhizome; but it requires constant attention to keep it free from moss, and wherever the latter has grown, even for a few days, it leaves a dry brownish patch on the frond. It is, therefore, best grown under a bell glass. It is found in the tropics of both hemispheres, and from China and Japan in the north, through Polynesia, to New Zealand, but seems only to extend as far south as the middle of the Middle Island. It is by no means rare in the North Island.

\section{TRIBE DAVALLIÆ. (Da-val-le-æ.)}

It is represented in New Zealand by two genera, viz:--Davallia and Cystopteris. Its characteristics are, sori marginal or sub-marginal, roundish, covered by reniform or sub-orbicular scale-like involucres, which are open at the apex, fastened broadly at the base, and open or free at the sides. 


\section{GENUS DAVALLIA. (Da-val-le-a.)}

Named after Edmond Davall, a Swiss botanist. Has sori intra or sub-marginal, globose or elongated, either laterally or vertically. Involucres terminal on the veins, various in shape, united or free at the sides, apex always open. Capsules stalked. Fronds various in size and division, herbaceous or coriaceous, veins always free, rhizomes usually creeping and scaly. Three sub-genera are recorded in the Colony.

\section{DAVALLIA FORSTERI. (Da-val-le-a Fors-ter-i.)}

This plant belongs to the sub-genus Humata, which has its involucres attached by a broad base, but the apex and sides free. It is said to have been gathered at Dusky Bay by Mr. Forster, the naturalist who accompanied Captain Cook's second expedition in $177^{2}$, and whose specimens are in the British Museum. It has never since beer found, however, though carefully sought for at Dusky Bay, and it appears either that the plants must have been destroyed by the whalers who afterwards occupied the bay, or that the specimens were actually gathered elsewhere (possibly in some Pacific island) but credited to Dusky Bay by mistake. This last seems now to be the general opinion of New Zealand botanists. I am unable to give a figure of it, but the following is the description. Stipes six to eight inches long, naked, strawcoloured. Fronds six inches long, rhomboid, quadri-pinnate; pinna and pinnules ascending, rhomboid, stalked, the lowest the largest, cuneate, truncate on lower side at base; final segments ligulate cuneate, two to four lines long, under half a line broad, texture sub-coriaceous, surfaces naked. Sori minute, terminal, with lamina produced on both sides as a border. Forster called it Adiantum clavatum. It is more nearly allied to a New Caledonian plant than to either of the other New Zealand ones, but has never been reported except from Dusky Bay.

\section{DAVALLIA NOVÆ ZELANDIÆ. (Da-val-le-a No-væ Ze-lan-de-æ.) \\ PLATE XVIII., No. 2.}

This is one of the most beautiful New Zealand ferns and fortunately is by no means rare. It belongs to the sub-genus Leucostegia. There are two forms of it generally known. The one has a moderately stout rhizome, which creeps very rapidly from the time when the first tiny fronds appear. This rhizome is furnished with light brown scales or hairs, and the fronds grow from it at some distance apart. The stipes is about half as long as the frond, reddish brown and polished, or with only a few hairs at the base. Rachis the same and flexuous. Frond generally six to eighteen inches long, four to eight inches broad, tri-pinnate, generally ovate or lanceolate in shape. Pinnæ stalked. Pinnules stalked, and divided into lanceolate segments. Ultimate lobes narrow and forked. Sori numerous on the side lobes of the segments. Involucres attached by a narrow base, and open at the sides and apex, bending right over 
and covering the sori. Foliage very narrow; in fact, mere veins with narrow wings. Called by Moore, "Acrophorus hispidus." It occurs throughout the Colony. The other form is a larger plant with triangular frond, wider foliage, and a stouter rhizome, which creeps so slowly that the fern will take many years to outgrow a six-inch pot. It also produces far more fronds than the other, and is altogether a handsomer plant. Both are found in rich soil in damp places, and generally in heavy bush. They are both easily cultivated in a greenhouse or case, but will not stand exposure to wind. They require light vegetable mould, and plenty of moisture in the surrounding atmosphere, but the second one less than the other. A third form was found by my eldest son, some years ago, when surveying in what is known as the "Tuhua country," at the head of the Wanganui river. Unfortunately, through the carelessness of the man to whom they were entrusted, the whole of the specimens were lost, except the pinna shown at plate XXVIII., No. 9, and it has been impossible to get others, owing to the locality being included in what is called the "King country." My son described the plant as producing its fronds so as to form a crown, and as having, in some instances, a caudex several inches high. The foliage of the pinna is like that of the form first described, but is far harsher, coarser, and more compact. I suspect that, when the plant is again met with, it will prove to be a form in which the rhizomes have become thickened, and have assumed an erect mode of growth, like those of the Australian Davallia pyxidata, and the African Davallia Canariensis, rather than a truly arborescent fern. In the "Journal of Botany" for 1875, page 78 , it is stated that the New Zealand Davallia had been found growing wild on the lower stones of a bridge over the river Swale, near Thirsk, in Yorkshire, in the previous year, it having probably been carried thither from some garden by a flood. This shows how plants introduced into a country may become accidentally acclimatised. The Australian Stags-horn fern, Platycerium alcicorne, was similarly discovered, several years ago, growing wild on Cadr Idris, a high mountain in North Wales, though no one could tell how it got there.

\section{DAVALLIA TASMANI. (Da-val-le-a Tas-man-i.) \\ PLATE XXIV., No. 5.}

This is one of the latest additions to the list of New Zealand ferns, having been found at the "Three Kings" islands, near the North Cape, in I887, by Mr. T. F. Cheeseman, F.L.S., curator of the Auckland Museum, to whom I am indebted for the specimen figured in the plate. It belongs to the sub-genus "Eudavallia," which has the involucres connected at the sides as well as the base, but open at the top, so as to form a sort of flattened oval cup, containing the sorus, and is closely allied to the ferns mentioned at the end of the last description. The rhizome is stout and creeping; the stipes long in proportion to the frond, light brown and smooth. Rachis and costæ the same, but narrowly winged, particularly at the junctions. The frond is broadly 
rhomboidal, tri or quadri-pinnate, and of a rather light green colour. The lower pinnæ are rhomboidal in shape, the lower side however being wider than the upper one; the higher pinna more lanceolate. They all branch right and left in pairs, and slope upwards. Pinnules oval or sub-lanceolate, and cut down nearly or quite to their costæ into triangular or fan-shaped segments, divided into two or three lobes. The sori are terminal on the lobes, the end of which is prolonged, so as to project a little beyond the involucre on both sides. Though this fern has only been found on an outlying island, it may occur on the main land near the North Cape, and is worth looking for. No one, I believe, has yet cultivated it, but it would no doubt grow freely, like those to- which it is allied, and would probably require less moisture than the other New Zealand Davallias, though the climate of the Three Kings is a humid one. It is allied to D. pyxidata and D. Canariensis.

\section{GENUS CYSTOPTERIS. (Sis-top-ter-is.) \\ "BLADDER FERNS."}

This genus has the sori globose on the backs of the veins. The involucres are membranous, and sub-orbicular, being attached to the frond by a broad base beneath the sorus, over which they bend so as, at first, to cover it like a hood, and give it the appearance of being enclosed in a bladder. As the sorus developes, however, the edges lift, and the hood is pushed back so as to allow the capsules to be seen around the sides and end of the involucre, but not next its base.

\section{CYSTOPTERIS FRAGILIS. (Sis-top-ter-is fra-gil-is.) \\ "BRITTLE BLADDER-FERN." \\ PLATE XVIII., Nos. 5 and $5 a$.}

This is one of the ferns coinmon to New Zealand and England, though there are greater variations in its shape in the former, owing to the greater range of altitude and temperature. The North Island plant, shown in figure 5, is scarcely, if at all, distinguishable from the more divided forms of the English one, but in the Middle Island it becomes longer and narrower, and at high levels assumes the stunted appearance indicated in $5 \mathrm{a}$, which is drawn from a specimen gathered by Professor Kirk, in the upper Waiau Valley, at an altitude of 4500 feet. It has an erect rhizome, which has a tendency to branch and produce several crowns, thus ultimately spreading over a considerable space. The stipes is rather long, slender, smooth and brittle, with a few small scattered scales towards the base. Rachis and costæ the same, but without scales. Frond lanceolate. Pinnæ and secondary pinnæ deltoid or lanceolate, and alternately arranged. Pinnules more or less narrowly fanshaped or oval, and divided into pointed lobes. The sori are very numerous, placed on the middle of veinlets running into the lobes; and as they develop, they become confluent, and nearly cover the under-surface of the frond with their black capsules. 
Involucres white, bladder-like, and membranous at first, but almost disappearing as the fructification ripens. The texture of frond is sub-membranous, colour light green, and the stipes and rachis contain very little woody fibre, and hence are very brittle. This fern has been gathered in the Wairarapa valley, and at various points from thence to Mount Egmont; so that it no doubt occurs sparsely over the southern half of the North Island. In the Middle Island it has been met with from Nelson to Foveaux Straits, but curiously enough at higher levels than those at which it is know to occur in the North Island. This may, however, arise from the fact that the higher levels of the North Island have been less explored than those of the Middle one; and thus it may yet be found at greater altitudes in the former. In the North Island, however, it has, I believe, only been found in the light bush, while farther south it occurs in open ground, in clefts of rocks.

It grows very freely, when cultivated in light soil and sheltered from wind, and soon fills the pot. Its delicate green colour makes it a favourite plant with fern-growers, and it sheds its spores so freely that any one who has a pot of it soon finds an abundance of seedlings coming up all about his fernery. It appears strange, therefore, that the plant is not more abundant in the Colony, as it seems to occur throughout the tropics, and both temperate zones. The reason probably is that its soft texture makes it particularly liable to destruction by slugs and similar insects.

TRIBE LINDSAYÆ. (Lind-say-æ.)

Has sori forming a line at, or very close to, the edge of the frond, which is divided into two thicknesses or involucres, the upper of which is of the texture of the frond, and the lower generally more membranous.

GENUS LINDSAYA. (Lind-say-a.)

This has the rhizomes creeping or tufted, the fronds generally compound or coriaceous, with free veins. Sori elongated, marginal or sub-marginal. Involucres double, and opening outwards.

\section{LINDSAYA LINEARIS. (Lind-say-a lin-e-a-ris.) \\ PLATE XIX., Nos. 4 and $4 a$.}

This fern has a thin, slightly-creeping, scaly rhizome, sending up numerous fronds of two different characters, barren and fertile. The barren ones have a moderately long stipes, which, as well as the rachis, is purple red or black, slender and shining. The frond is generally about four inches long, by one inch wide, oblong and pinnate. The pinnæ are usually about half an inch long, alternate, stalked, and irregularly fanshaped; the outer edge being cut into lobes of greater or less depth, and the lower half of the fan being larger than the upper. These barren fronds generally lie inore or less prostrate. The fertile fronds stand erect, and have a much longer and stouter 
stipes and rachis; the whole length of the frond with its stipes being from eight to twelve inches or more. It is also narrower than the barren frond, though, like it, only pinnate. The fertile pinnæ are also fan-shaped, but far shorter and broader than the barren ones, though also with the lower half of the fan the larger. The sori and involucres are very large, and extend all along the outer edges of the pinnæ, but not along the sides. Veins indistinct. This fern occurs throughout the Colony, as well as in the adjacent and Chatham islands. It is usually found growing among manuka scrub, but sometimes among grass, or on cold swampy soil at high levels. In these last cases, however, it is much stunted, the fertile fronds being seldom more than three inches high, and the barren ones even shorter. Though usually found in poor soils, and often in exposed situations, it is a very difficult plant to cultivate, requiring to be kept in a Wardian case, or under a bell-glass and to have its fronds cut away at starting. The typical form, which was first described from Australian specimens, is but shallowly lobed, and occurs in New Zealand also. The more common New Zealand form, however, has rather deep lobes, particularly in the barren fronds, which Mr. Colenso regards as entitling it to be classed as a distinct plant, under the name of "Lindsaya trilobata." In both forms, the lobing almost disappears in the fertile pinnæ. The fern occurs also in Australia, Tasmania and New Caledonia.

\section{LINDSAYA TRICHOMANOIDES. (Lind-say-a tri-kom-an-o-id-ees.)}

PLATE XIX., No. 1.

This beautiful ;fern has a slightly-creeping, brown, scaly rhizome, from one sixteenth to one eighth of an inch thick, from which numerous fronds spring. The stipes is usually about as long as the frond, of a bright reddish brown colour, and quite smooth and shining, except at the very base, where there are sometimes a few small scales. The rachis is like the stipes. Frond broadly lanceolate, divided into distant, broadly lanceolate, opposite pinnæ, which are cut down, nearly or quite to their costæ, into wedge shaped pinnules, more or less deeply lobed on their outer edges, the middle lobes being often longer than the others. The sori are sub-marginal, continuous round the outer edges of the lobes, and the lower involucres narrower than the upper ones. The texture of the frond is sub-coriaceous, and the colour rather bright green. The veins are indistinct, though more discernible than those of the preceding species.

This fern is found throughout the Colony, but is more common in the North Island than farther south. It only occurs on high, dry ridges covered with bush, and is nowhere very abundant. Like the preceding one, it is impatient of being shifted, but can be moved with care, and will thrive in leaf-mould or pounded rotten wood. It is best, however, to cut away the whole of the fronds, and let the plant produce new ones, as its roots get fairly established. It occurs in the Australian Colonies and Fiji. It, and L. viridis, belong to the sub-genus Isotoma, which means cut into equal divisions. 
There is a second form called "var. Lessoni," or sometimes "Lindsaya Lessoni," Plate XIX., No. 3, as some consider it a distinct plant. It is smaller, stiffer in its growth, and less divided ; being simply pinnate, or only bipinnate on the lower pinnæ. It is only known to occur in the North Island, and is scarce even there. It is found in similar situations to the other.

\section{LINDSAYA VIRIDIS. (Lind-say-a vir-ri-dis.) \\ PLATE XXI., No. 2.}

This is the most beautiful of the New Zealand Lindsayas, and is scarcer even than L. Trichomanoides. It has a short ereet rhizome from which numerous fronds arise. The stipes is short, reddish brown or black, polished, but with a few hairs or scales at the base. Rachis and costæ the same. Fronds sometimes eighteen inches long, lanceolate, and bi or tripinnate. The pinnæ are alternately arranged and slope upwards. They vary in shape from lanceolate to wedge-shaped, in various fronds, and are divided, sometimes twice, into broad wedge-shaped segments, cut down to the costæ. The texture is sub-coriaceous, and the colour light yellowish green. The sori occupy the ends of the ultimate segments, which open into flattened trumpet-shaped involucres, containing them. The edges of the involucres are often slightly-toothed. This fern is peculiar to New Zealand, and is usually found on the faces of dripping cliffs, but occasionally on boulders in the beds of streams, in both cases, of course, growing among moss. It differs from most delicate ferns, in loving sunshine and hating shade. If coarse ferns, such as Lomaria procera, or Polypodium pennigerum, invade a cliff on which it grows, and overshadow it, it quickly dies out. Even Adiantum affine will kill it, when the former attains any size. It has been found at various places from North of Auckland to Reefton, near Westport, but seems to be more plentiful in the country between the Tararua range and Mt. Egmont than anywhere else, the neighbourhood of Wanganui being, as it were, its headquarters. It is a very easy fern to cultivate, and will grow well in a greenhouse, provided it is planted in light sandy soil, and the pot is kept standing in an inch or two of water, so as to enable the roots to get as much moisture as they like. I have grown it thus for many years; but it may be noted that, under this treatment, the fronds are shorter and broader than when hanging on the face of a cliff.

\section{TRIBE PTERIDIÆ. (Pter-id-e-æ.)}

Has oblong or linear marginal sori. Involucres of the same shape as the sori, and formed of the more or less altered or reflexed margin of the frond, opening inwards.

\section{GENUS ADIANTUM. (A-de-an-tum.)}

So called from the Greek word "adiantos" dry, because water will not lie on the surfaces of ferns of this genus, on account either of oiliness or of slight hairiness. The sori are marginal, varying from globose to linear, usually numerous and distinct, but 
sometimes confluent and continuous. Involucres of same shape as the sorus, and formed of the reflexed margin of the frond, bearing capsules on the under side. All the New Zealand Adianta belong to the sub-genus Euadiantum, which has the veins not anastomosing, and the first five belong to what is called the "Poly-sorus group."

\section{ADIANTUM DIAPHANUM. (A-de-an-tum di-af-an-um.)}

PLATE XIII., No. 5.

This fern has slender creeping rhizomes, and small tubers on the roots. The fronds grow in small tufts, with numerous roots. The stipes is black and smooth, and about as long as the frond: rachis also black and smooth. The frond varies from four to eight inches in length, and in its simplest form is narrowly lanceolate and merely pinnate. Sometimes, however, a branch of the same form grows out from the base of the main frond, and nearly at right angles to it, and more rarely a similar branch is found on the other side. The pinnules are large in proportion to the frond, shortly stalked, and oblong, the stalk being attached to one angle, and the opposite one rounded. Their texture is thin, and colour very dark green. The lower ones sometimes show a tendency to divide. The sori are numerous, placed in indentations in the upper and outer edges of the pinnules, and kidney-shaped. The involucres are of the same shape, and of a lighter green than the frond.

The plant is found throughout the Colony, but is more common in the north than in the south, and seems confined to level, and usually to alluvial ground, among high bush, though it grows in lighter bush near Auckland. It is very easily cultivated, and very quickly covers the whole surface in the pot with its delicate fronds. I notice that, in a shady place in a greenhouse, the colour becomes far lighter than when growing out of doors, or in a cooler place, and the plant becomes more attractive. Some confusion has arisen about the New Zealand Adianta, owing to their being incorrectly named by Dr. Hooker, who called this plant "Adiantum affine." No doubt it was this which led Mr. Colenso to describe it afresh, under the name of "Adiantum heteromorphum," on account of its varying form. It grows in S.E. China, Aneiteum, Java, Fiji, New Caledonia, Norfolk Island and New South Wales, and is also called A. setulosum.

\section{ADIANTUM AFFINE. (A-de-an-tum af-fi-ne.)}

PLATE VI., No. 1.

Confined to New Zealand and adjacent islands. Has a creeping, scaly, black or dark brown rhizome, about an eighth of an inch in diameter, producing scattered fronds. The stipes is about as long as the frond, black and smooth, with a scale or two at its base. The rachis and costæ are also black and smooth. The frond is usually merely pinnate with alternate pinnæ, but large fronds are more branched, and sometimes bi-pinnate in the lower portion. The pinnules are rather oval in shape, but pointed towards the stalk: texture coriaceous: colour dark green. The sori are 
numerous, placed in indentations in the upper and outer edges, and kidney-shaped. Involucres same shape as sori, formed of reflexed margin, and of a light green colour. The fern occasionally grows eighteen inches high, and is found throughout the Colony, but only at moderately low levels, and seldom far inland. It also occurs at the Chatham Islands, the variety "Chathamicum" found there being very coarse. It is very easily cultivated in light soil and leaf-mould. It was called by Dr. Hooker "Adiantum Cunninghamii." There are various forms of it, differing chiefly in size and number of branches, but presenting no specific distinctions. The most noticeable is a small harsh-textured form found in dry places near Napier and elsewhere.

\section{ADIANTUM FULVUM. (A-de-an-tum ful-vum.)}

PLATE VI., No. 4.

Though this fern is separately classed, I doubt whether it is really distinct from the previous one, as I have repeatedly found intermediate forms, particularly large ones, which could scarcely be assigned to either species, rather than the other. In its typical form, this fern has a rougher rhizome, and more hairy base to its stipes than the other. The stipes and rachis throughout are rough to the touch, and often red rather than black. The frond is more branched, being sometimes partially tri-pinnate, and the pinnules are longer, narrower, and more pointed. This last peculiarity, however, disappears in large fronds, and their pinnules are often nearly round, as are those of similar fronds of A. affine. The sori are similar to those of A. affine, but larger, particularly in large fronds; and the involucres are often nearly white. It also grows eighteen inches high occasionally.

It is found in Australia and the islands northward of New Zealand as far as Fiji, and is most plentiful in the northern part of the North Island, though it occurs in the Middle one as far south as Banks' Peninsula. Like the preceding one, it seems confined to the low country near the sea coast, and I have noticed that it grows in drier places than the other, generally on ridges, or steep hill-faces. In one case, near my own house, a large patch of it has so completely changed its character that I do not think anyone but myself would take it for anything but A. affine, and I can only be sure it is A. fulvum through having gathered its fronds for the last thirty years. It was perfectly typical, red stipes and all, when I first knew it, but the change has occurred gradually, as the bush got opened up by the stock, and the plants have deteriorated. It is easily cultivated, in the same manner as Adiantum affine.

ADIANTUM FORMOSUM. (A-de-an-tum for-mo-sum.)

"PLUMED MAIDENHAIR."

PLATE XIV., No. 6.

This is by far the largest of New Zealand Maidenhairs, being four feet, and sometimes five feet high, with more than twenty branches, and over 1000 pinnules. 
The rhizome is short, thick, creeping and scaly; and the stipes long, black and glossy, yet rough to the touch. In some localities, it is slightly hairy, particularly towards the base. Rachis and costæ black, rough, and shining below, but slightly downy above. The frond is broadly rhomboidal, and repeatedly branched, the ultimate pinnæ being much prolonged. The pinnules are rather large in barren fronds, but small in fertile ones, and vary in shape from rhomboidal and oblong to almost round with lobed edges. Texture coriaceous : colour olive green. The sori are numerous, and vary considerably in size in different fronds. They are usually on the lobes rather than in indentations of the edges, and like the involucres, are often oblong rather than kidney-shaped.

I only know, with any certainty, of this fern occurring in the North Island, though I have heard it said that it has been found at one place in the Nelson Provincial District. It is, however, met with in the neighbourhood of Kaipara, and beside the Manawatu River and its tributaries, from near Woodville to below Palmerston North, where it grows abundantly in the sandy alluvium by the river side. It used to occur in the bush farther from the river, but is fast disappearing as the bush is cleared. It is a noble fern and easily cultivated in very light sandy loam, but is not easily lifted, the rhizomes being often a foot or more below the surface of the sand, which has been deposited above them by floods. I have noticed that the deeper they are buried, the finer fronds they produce; but it would be useless to plant them deep, unless in very light sand, such as that in which they naturally grow, as the fronds would not be able to force their way up. The fern is also found in the southern parts of Australia. Baron Von Mueller, of Melbourne, regards this and the two preceding ferns as merely forms of one plant, though they differ so much in size and division.

\section{ADIANTUM HISPIDULUM. A-de-an-tum his-pid-u-lum.)}

PLATE XIII., No. 1.

This fern has a stout, slowly-creeping, scaly rhizome, sending up numerous fronds. The stipes is long, stout, and ereet, of a dark brown colour, and thickly covered, when young, with short white hairs, which fall off afterwards. At the top of the stipes the plant usually forks into two unequal halves, each of which divides and divides again till it assumes a fan-shaped outline. The branches are long, narrow, tapering, and alternately pinnate. The pinnules are oblong or slightly tapering, with the lower and outer edges somewhat rounded and indented or toothed. Sori and involucres small and numerous, and placed in the indentations of the upper and outer edges. Texture coriaceous, and rough to the touch. Colour olive green. It is also called "Adiantum pedatum" and "Adiantum pubescens." This fern is found throughout Central Africa, in Southern India, Mauritius, Pacific Islands, Australia, and the Chatham Islands. It occurs in tolerable abundance from about Auckland northward, and is 
stated in Mrs. Jones's and Mr. Thompson's books to be common as far south as Cook's Straits, but I have never heard of its being gathered south of Manukau, unless at Banks's Peninsula, which I think doubtful, as I find it will only grow in a greenhouse, even in Wanganui. In light soil, and with moderate warmth, it grows freely and produces spores abundantly. It soon spreads all over the surface of the pot, and in the spring looks very handsome, as the young fronds vary in hue from coppery-brown to rose-colour.

\section{ADIANTUM ÆTHIOPICUM. (A-de-an-tum E-the-o-pic-um.) \\ "AFRICAN MAIDENHAIR." \\ PLATE XVII., No. 1.}

This plant differs from the others, and belongs to what is called the "Capillus Veneris" group, hecause the ferns composing it more or less resemble the European Maidenhair. This group has its fronds at least bi-pinnate, its pinnules more or less fan-shaped, and stalked near the centre, and its sori obversely kidney-shaped. The New Zealand plant has widely creeping thizomes producing tufts of fronds at intervals. The stipes and rachis are slender, dark brown and polished; the former about half as long as the frond, which is sometimes fifteen to eighteen inches long by six to nine inches wide, triangular in shape, and tri or quadri-pinnate. A very large proportion of the fronds are barren, and in these the pinnules are quite round with entire edges. In the fertile fronds, however, they are more or less wedge-shaped towards the stalk, and indented along their outer edge. Texture thin and habit drooping. Sori and involucres rather large, kidney-shaped or oblong, and placed in the indentations of the edge. The colour is a pale yellowish green.

This fern, which is also called "Adiantum assimile," and by several other names, occurs throughout Africa, from Southern Egypt to the Cape, throughout America from California to Chili, as well as in Australia and the intervening islands. It is abundant in the North Island from Auckland northward, has been gathered at Eltham in Taranaki Province, and is said to have been found near Collingwood and on Banks's Peninsula; but, I believe, has never been met with anywhere else in New Zealand, unless a fern found by Mr. G. Roberts, at Abbey rocks near Hokitika, but of which I have seen no description or specimen, should be it. The plant is easily grown, and particularly suited to being cultivated in hanging baskets, as its rhizomes will put forth tufts of fronds wherever they get near the outer surface of the soil in the basket, and these fronds will grow just as well downwards or sideways as upwards, and thus a handsome mass of drooping foliage is produced.

\section{GENUS HYPOLEPIS. (Hi-po-lep-is.)}

Hypo under, lepis a scale. Has the sori marginal, in indentations of the margin of the frond; more or less reniform, but often considerably elongated. Involucres 
same shape as sori, membranous in texture, formed of reflexed margin. All the New Zealand plants of this class belong to the sub-genus Euhypolepis, which has the rhizome creeping; the frond ample and tri or quadri-pinnatifid. The distinction between this class and Adiantum is that it has its sori on the back of the frond, and covered by the reflexed involucre; while in Adiantum the sorus is on the back of the involucre itself. Thus till closely examined the fructifications of the two classes appear to be alike, though in some Adianta they are on the ends of lobes or on straight edges of pinnules.

\section{HYPOLEPIS TENUIFOLIA. (Hi-po-lep-is ten-u-if-o-le-a.)}

PLATES XXIV., No. 3, and XXVII., No.4.

Has rather stout, scaly, dark brown, widely-creeping rhizomes, producing scattered fronds. Stipes about half as long as frond, erect, stout, naked or slightly tomentose. Rachis and costæ the same, but usually more tomentose. Fronds varying from triangular to oblong, and from one to three feet long, tri or quadri-pinnate. Pinnæ ovate or lanceolate, pinnules the same, cut into narrow oblong toothed lobes. Texture herbaceous or sut-coriaceous : colour generally dark green. Sori in the indentations between the lobes; with margin of frond doubled over to form a spurious involucre. This distinguishes the class from Polypodium which has the sori naked and placed nearer to the costæ, but as a matter of fact the two classes run into each other to such an extent that Sir W. Hooker said he could see no good specific distinction between two New Zealand Hypolepides and Polypodium punctatum, particularly in its variety " rugulosum." Of course the typical plants differ, but there are frequent intermediate forms which are difficult to classify; indeed, a better classification is wanted. The plant which I have just described is classed by different authorities as a Cheilanthes and a Lonchitis, which illustrates this difficulty.

It occurs throughout the Colony among scrub and light bush, usually on the margin of bush, and often springs up in abandoned cultivations. It is also found in Australia, Tasmania, Java, Polynesia and Chatham Islands. It is easily grown, but is more suited to a rockery than to pot culture, as its rhizomes soon overrun the edge of a pot. Leaf-mould suits it best. It is also called "H. Dicksonioides," "Cheilanthes ambigua," "C. arborescens," "C. pellucida," and "Lonchitis tenuifolia." There is a form, found in the Canterbury district, which has been called "Dicksonia dubia," and "Dennstædtia dubia." It differs from the ordinary one in having what in the latter are the ultimate lobes again forked or indented in the edges. The sori, which are minute, are placed on small lobes in the bottom of the sinus, and not in the sinus itself, The stipes is long and the frond more compact than usual, though it is of the triangular type. 


\section{HYPOLEPIS MILLEFOLIA. (Hi-po-lep-is mil-le-fo-le-a.)} PLATE III., No. 2.

Has stout creeping rhizomes, which are smooth except by the bases of the stipites where there are a few scales. Stipites scattered, erect, smooth or very slightly hairy, and straw-coloured or light brown. Fronds not more than eighteen inches long, rather broadly ovate or lanceolate, and tri-pinnate. Pinnæ and pinnules the same; the latter deeply cut into long narrow teeth or lobes. Texture softly herbaceous with a few hairs on the under side. Sori small, placed under reflexed edges among the lobes of the pinnules. This is quite an Alpine form, and confined to New Zealand. The only places in the North Island at which I believe it has ever been gathered are beside the ice-cold streams that flow from beneath the cones of Ruapehu and Mt. Egmont, but it seems to occur all along the eastern side of the Southern Alps at high altitudes, descending to about 1500 feet at Dunedin, and to even lower levels farther south. It has been successfully acclimatised in the Botanical Gardens at Christchurch, apparently by accident, and a plant (one of several) that I lately brought from Dunedin seems thriving, though a number of plants, which I and other fern growers have previously procured from there, and from Invercargill, have always died. Probably I was more careful to select young plants, and to avoid injuring the rhizome than most people would have been; but plants which I have brought from Ruapehu with equal or greater care, would not live.

\section{HYPOLEPIS DISTANS. (Hi-po-lep-is dis-tans.) \\ PLATE XXVIII., No. 6.}

Has a rather slender, creeping, rough, scaly and woolly rhizome, producing scattered fronds. Stipes four to six inches long, very slender, reddish brown, glossy yet rough to the touch, but sometimes velvety in the northern forms. Rachis and costæ the same, but the latter shading gradually into the colour of the frond. Frond often three to four feet long, narrowly oblong or tapering, and bi-pinnate. Pinnæ far apart, and growing in pairs at right angles to the rachis, narrow and tapering. Pinnules generally oblong or oval, rather deeply cut into rounded lobes, with slightly toothed edges. Sori small, and placed in the indentations. Texture thin and herbaceous, yet harsh to the touch: colour dark bright green.

This fern is peculiar to New Zealand and the Chatham Islands, and was formerly very common, but is now getting scarce in many localities, owing to the cattle destroying it. It is occasionally, but rarely, found on rotten logs and stumps in bush and grows very large in such situations, sometimes producing masses of interlacing fronds ten feet in diameter. It is more commonly found, however, on the grass tussocks in swamps, particularly on dead and rotting tussocks. I have also seen it on mossy ground near Auckland, and at Rotorua it is very plentiful among the hat springs and often grows in crevices of the stones, but in a stunted form. It is very easily 
cultivated in rotten sawdust, pounded rotten wood or finely crushed peat; in fact, in any rotten vegetable substance, through which its rhizomes and young fronds can push their way readily. Its long delicate drooping and interlacing fronds make it very suitable for cultivation in hanging baskets, as it likes light and does not need much watering.

\section{GENUS CHEILANTHES. (Ki-lan-thees.)}

From the Greek words, cheilos a lip, and anthos a flower, referring to the round sub-marginal sori. This genus has its sori terminal or nearly so on the veins; at first small, distinct, and sub-globose, but afterwards more or less confluent. Involucres formed of altered and reflexed margin of the frond, sometimes in rounded and distinct lengths, and sometimes more or less confluent, but never quite continuous. The two plants generally recognised in New Zealand, both belong to the sub-genus Eucheilanthes, which has its involucres more or less confluent, fronds not produced nor scaly beneath, and segments large and flatter than in the other sub-genus Physapteris; but we have a third species not yet classed.

\section{CHEILANTHES TENUIFOLIA. (Ki-lan-thees ten-u-if-o-le-a.)}

\section{PLATE XXI., Nos. 2 and 3.}

Has an erect rhizome covered with silky scales and sometimes much flattened on the top. Stipites tufted and occasionally extremely numerous, varying greatly in length as much as from one to four inches in fronds of equal size on the same plant, dark reddish brown or purplish black, glossy but slightly hairy at base. Rachis the same and sometimes narrowly winged. Fronds triangular, oblong or broadly lanceolate, spreading or erect, tri-pinnatifid. I'innæ broadly triangular, alternate or sub-opposite, and slightly overlapping. Professor Kirk says that they ascend at an acute angle with the rachis, but in several of my plants which came from the same localities, Lyttelton and Lake Whakatupu, as those from which he described the fern, they stand out at right angles, and in some fronds the lower ones are even a little deflexed. Pinnules tapering or oval, and cut down to the costæ, or nearly so, into oval or oblong segments which are sometimes slightly lobed. Terminal pinnules often very long, forming a sort of tail to the pinna. Sori often confluent, and projecting beyond the margin of the frond. Involucres more or less toothed or indented. Texture coriaceous; colour bright yellowish green. Dr. Hooker says it has a few silky scales on the stipes; but other authorities do not mention them. This fern is found all over India, in China, Malaya, Polynesia, Australia, Tasmania, and South Tropical America; but it is rare in New Zealand, being reported only from Hawke's Bay, Wanganui, and Taumatamahoe, in the North Island, and the Port Hills near Christchurch, Banks's Peninsula, and Lakes Hawea and Whakatupu in the Middle one. It is a small plant, however, seldom more than eight or nine inches high, and as it grows on very dry clay hills, or 
in crevices of rocks at high levels, it may be much more common than is generally supposed. This fern varies considerably in appearance in different localities. I have one from Queenstown on Lake Whakatupu, of which the fronds correspond exactly with Professor Kirk's description; the pinnæ being very ascending and having small, very scattered pinnules. In the others they do not ascend, or do so but slightly. The Lyttelton plant has its fronds narrower in proportion to their length, and the pinnæ are shorter with larger pinnules, and vary from ascending to deflexed. The Wanganui one is altogether more compact and squarer in the frond, with very ascending pinnæ, approximating closely to Cheilanthes Sieberi. It is very easily cultivated, as it likes a dry situation, and does not require much water. I have seen it cultivated in a hollowed fern-tree stump in a garden. Its bright colour and finely divided foliage make it very attractive, and fern lovers should try to obtain plants of it. It is apt to to stick to the paper in pressing.

\section{CHEILANTHES SIEBERI. (Ki-lan-thees See-ber-i.) \\ PLATE XXI., No. I.}

Has also an erect rhizome, and crown of fronds. Stipes long, stout, erect, dark glossy brown, with a few hairs at base. Rachis stiff, round and polished. Frond long oblong or lanceolate, bluntly pointed at the top, erect, and bi or tri-pinnatifid. Pinnæ arranged in pairs usually at a considerable distance apart. From Professor Kirk's mentioning the ascending habit of the pinnæ as a distinguishing characteristic of $\mathrm{C}$ tenuifolia, one would infer that the pinnæ of C. Sieberi stood out at right angles to the rachis or nearly so, yet the frond figured in the plate, for which I am indebted to the Professor himself, has its pinnæ ascending; from which it would appear that both plants have their pinnæ set sometimes horizontal and sometimes ascending. The pinnæ are triangular and the pinnules triangular or oblong, the lorvest ones being pinnate at their bases, and all divided into segments, the edges of which are sometimes entire and sometimes indented or lobed. The sori are seldom confluent, and do not project beyond the edge of the frond. Involucres small, rounded, and with entire edges. Texture coriaceous; colour yellowish green. This fern is found in Australia and New Caledonia as well as in New Zealand. It is common on the volcanic rocks about Auckland and thence to the Northern extremity of the Colony; and as it is found in Canterbury and Otago it probably occurs in the intervening country, though from the imperfect botanical exploration of much of the North Island, it has not yet been observed.

Dr. Hooker considered the two plants identical, and I am by no means certain that they are really specifically distinct; as the Wanganui form of what is known as C. tenuifolia, Plate XXI, No. 2, appears to me to have all the characteristics of Sieberi, except that the frond is far broader in proportion to its length, and the pinnæ 
are closer together and very ascending; on the other hand, my Lyttelton plants are producing elongated fronds with slightly ascending pinnæ under cultivation. Cheilanthes Sieberi is easily cultivated in the same manner as $C$. tenuifolia; but though generally larger, it is not so handsome a plant.

\section{CHEILANTHES (NEW SPECIES). (Ki-lan-thees.)}

This little fern has lately been found by Mr. A. C. Purdie at what is called "The Peninsula," near Dunedin, and has not yet been named. In its general appearance it corresponds with Cheilanthes Sieberi, but its ultimate divisions are round or only slightly oval instead of oblong and overlap each other considerably. The sori are round and quite separate, and the marginal involucre is less bent over. The stipes is furnished with scattered broad silky white scales; but the great peculiarity which distinguishes it, and seems to place it in a different class of Cheilanthes, is that the rachis and costæ are thickly furnished with similar scales which lie flat against the under-surface of the frond, and cover nearly half of it. It seems to correspond pretty well with the description of "Cheilanthes hirta," a South African fern also found in Bourbon, Java and China, as given in the Synopsis filicum, and may be a form of that plant, or of the South Indian "C. bullosa," or even a connecting link with Nothochlæna, as there is a doubt whether the two genera are really distinct.

\section{GENUS PELLEA. (Pel-lœ-a.)}

So called from the Greek word Pellos which expresses the dark olive green of the fronds of this class. It has intramarginal sori, on the ends of veins. These are at first dot-like and distinct, or barely touching each, but as they develop they unite and form a broad line just within the margin of the frond, which curls over continuously to form the involucre, but sometimes very narrowly. Veins free. The New Zealand species belong to the sub-genus Platyloma, which has the texture coriaceous, veins usually indistinct, ultimate segments broad and flat, and the involucres so narrow as soon to be overgrown and concealed by the capsules.

\section{PELLCEA FALCATA. (Pel-lœ-a fal-ca-ta.) PLATE XVIII., "No. 4.}

Has widely creeping, dark brown, scaly, harsh rhizomes. Stipes frequent, erect, dark-coloured and smooth, sometimes slightly hairy or scaly and generally about half as long as the frond. Rachis similar to the stipes. Frond from a few inches to three feet long, simply pinnate. Pinnæ numerous, and placed alternately, stalked, long, narrow, pointed, and generally more or less curved upwards, whence the name, which means sword-shaped. Texture harshly coriaceous and shining. Colour dark olive green Sori broad, extending all along the margins of the pinnæ. Involucres so narrow as to be soon hidden by the capsules. It is also called "Platyloma falcata." 
This fern is found in India, Malaya, Australia, Tasmania, and some of the Pacific Islands. It is only known to have been found in New Zealand as far south as Nelson, and is more common north of Auckland than in any other part of the North Island, though rarely met with even there. It is easily cultivated and spreads rapidly, but requires a little warmth and shelter. It likes light soil and leaf mould, but does not need much water.

\section{PELLEA ROTUNDIFOLIA. (Pel-lee-a ro-tun-dif-o-le-a.) PLATE XIV., No. 2.}

This plant creeps less than the preceding, and has rather a stouter rhizome, in proportion to the size of its fronds. The stipites are numerous, erect, more or less bristly or scaly, dark brown or black and often nearly as long as the frond. Rachis similar to the stipes. Fronds seldom more than twelve inches long, oblong or tapering and pinnate. The pinnæ are alternate, round, oval, or pointed, more shortly and less distinctly stalked than those of P. falcata, and sometimes even narrowly sessile. The lower pinnæ are sometimes auricled or lobed, and I have even found fronds in which they were divided into tibree distinct pinnules. Sori forming short broad lines on both sides of the pinnæ, and soon covering the involucres. Colour olive green; texture harshly coriaceous. Also called Platyloma rotundifolia.

Abundant in most parts of New Zealand on dry hill-sides, and in crevices of rocks, and found also in Norfolk and Chatham Islands. I am not at all certain that it is not merely a form of $\mathrm{P}$. falcata, for though the typical forms are very distinet, yet they seem to pass into each other by imperceptible gradations. The chief difference lies in the stipes and rachis, being smooth in one plant and bristly in the other. P. rotundifolia is easily cultivated like the preceding one, but in both the pinnæ are very apt to drop off, leaving the stipes and rachis as a mere barren stalk.

\section{GENUS PTERIS. (Pter-ris.)}

So called from the Greek word Pteron a wing. It is, in fact, the Greek name for bracken, and just as the term "fern" which is commonly applied to bracken, has come to be extended to all filices, so the word "pteris" is used botanically, in combination with something else, to express many other ferns; though standing alone, it signifies merely the bracken and the plants closely allied to it.

The genus is characterised by having marginal sori, which are linear and continuous, and arranged on a slender thread-like receptacle in the axis of the involucres. These last are of the same shape as the sorus, and formed of a thin continuation of the margin of the frond, turned back so as at first quite to cover the sorus, but afterwards more or less opened inwards, so as to show the capsules. Three sub-genera Eupteris, Pœsia and Litobrochia are represented in New Zealand. In Eupteris the veins are all free, and the involucres single. 


\section{PTERIS TREMULA. (Pter-ris trem-u-la.) \\ "SCENTED FERN." \\ PLATE XXIII., No. 2.}

This very handsome fern has a short erect rhizome producing fairly numerous fronds. The stipes is long (often longer than the frond), stout, erect, usually dark reddish brown and shining. Rachis and costæ also smooth and similar in colour. Frond rhomboidal bi or tri-pinnate. Pinnæ usually sub-opposite, ascending. Pinnules cut right down to the costæ, into long narrow, ascending lobes, which are much broader in barren fronds than in fertile ones, being quite linear in the latter. Texture herbaceous or sub-coriaceous. Colour usually rather bright green, with sometimes a reddish tinge. Sori sub-marginal on both edges of lobes. Involucres narrow.

This fern is found in Australia, Tasmania, and some of the islands north of New Zealand as well as in the Colony, and a plant called "Pteris Chilensis," differing from it only in having deeply toothed margins to its barren lobes, occurs in the western parts of South America and its outlying islands. In New Zealand, Pteris tremula is abundant in the North Island, but rare in the Middle one, where it seems only to occur in the northern half. It often grows five feet high, and may be at once distinguished by the strong aromatic odour, something like camomile, which its foliage emits when bruised. In summer time, surveyors cutting lines through the warm sheltered gullies in which it abounds, often find the smell so strong as to be unpleasant, and I have heard it called the "Stinking Fern" on this account, though many people rather like the scent. It is seldom found in high bush, as it evidently prefers a fair amount of sunlight, and is more frequent on rather dry soil, on hill-sides, than in wet ground at the bottom of a gully. It is easy to cultivate in rich light soil, and produces spores so freely that any one growing it soon has an abundance of seedling plants : but it is liable to be cut by sharp frosts, though slight ones will not hurt it. It is said to ascend to a height of 3000 feet in the northern part of the Colony, but I have never myself seen it even half that height above sea-level, in the country north of Cook's Straits; and it probably does not ascend even so high as this farther south. I have two crested plants of it, and some others in which the foliage is almost as curly as parsley; but as generally happens with these abnormal forms, they are all barren.

\section{PTERIS LONGIFOLIA. (Pter-ris Lon-jif-o-le-a.) \\ PLATE XXV., No. 7.}

This fern was reported, about five years ago, as having been gathered in the vicinity of Lake Tarawera, and as that region was buried more or less deeply by the eruption of June, 1886, I should not have noticed it, but for being lately told by $\mathrm{Mr}$. J. B. Armstrong, of Christchurch, that he has twice had specimens sent to hirn by persons on whom he thought he could rely, and who stated that they had met with the 
fern in the neighbourhoods of Napier and Gisborne respectively. As the plant occurs in Australia, and the eastern side of the North Island has a climate more nearly resembling the Australian one than any other part of the Colony, I have thought it best to include it as doubtfully a New Zealand species, just as Davallia Forsteri is always so classed, so that if any of my readers should come across the fern they may be able to identify it. The rhizome is short, erect and scaly. The stipes short, and both it and the rachis are stout, erect, light brown, and thickly covered with whitish hairs. The frond, which is sometimes eighteen inches or two feet long, is narrowly lanceolate and simply pinnate. The lateral pinnæ are ascending, opposite or subopposite, long, narrow, and tapering with rounded ends, and their edges are finely serrated though the serration disappears along the fertile portions of the pinnæ. The terminal pinna is about twice as long as the others and sharply pointed or tailed. The sori are broad, light brown, and do not extend to either end of the pinna. They are often confined to the upper half of the frond, the pinnæ of the lower portion being barren. Colour medium green. Texture coriaceous; veins indistinct, free and forked. The plant is easily cultivated, and rather a favourite one with fern-growers at home. I have also seen it in ferneries at Christchurch, but have never heard of any one but myself in the North Island cultivating it. If, however, plants of it occur in ferneries at Gisborne and Napier, spores from dead fronds which had been thrown out might get scattered by the wind and produce plants, but this would hardly account for the Tarawera example.

\section{PTERIS LOMARIOIDES. (Pter-ris lo-ma-re-o-i-dees.) PLATE XXV., Nos. 4 and 4 a.}

In volume XII of Philosophical Transactions, page 380, the Revd. W. Colenso describes, under the above provisional name, a fern of which a single barren frond had been brought to him in 1872 by an acquaintance who had gathered it in a patch of bush by the roadside near Tapuaeharuru. His description is as follows :- "Stipe (upper part only) five inches long (?), erect, straight, slender, naked, smooth, channelled above, straw-coloured. Frond six and a half inches long, five inches broad, symmetrical, broadly round, cordate (in outline), pedate, smooth, glabrous, very membranaceous, semi-transparent, colour (dry) a light olive green, pinnate, two pairs only and one long terminal segment five and a quarter inches long, ten lines broad, petiolate, linear lanceolate (together with pinnæ) decreasing but little and very gradually downwards, sub-acuminate, acute. Pinnæopposite, linear-lanceolate, oblique, obtuse, the two pairs one inch apart on rachis, upper pair sub-sessile and slightly decurrent on upper side three and three-quarter inches long nine lines broad; lower pair petiolate and pedate, slightly decurrent on upper side, three and a half inches long eight lines broad, lowermost pedate segments one and three-quarter inches long, six lines broad, sub-sessile, dimidiate and curved upwards, all four pinnæ inclined 
inwards and upwards; veins regular and parallel, conspicuous, fine, pretty close (about two and a quarter to a line), free and simply forked, with clavate apices, terminating within the margin, which is slightly cartilaginous and crenulate, and closely and finely serrulate, particularly towards and at apices of pinnæ and terminal segments; midrib finely channelled above, and very conspicuous on under surface, slightly puckered, evanescent towards apices of pinnæ, very light straw-coloured, hairs (debris of, remaining in lacunæ in axils and bases of pinnæ) bright red brown."

Unfortunately the Rev. gentleman sent the specimen home to the Royal Herbarium at Kew; and as I was therefore unable even to borrow it, I have been obliged to reconstruct the frond as it were from his description. No doubt my drawing, Plate XXV, No. 4, is not quite accurate, but still it ought to be sufficiently near to enable the fern to be identified, for, as Mr. Colenso says, "it does not remind one at first sight of any other of our New Zealand ferns." Farther on he says, "A plate of Pteris cretica in Beddome's ferns of South India, has a tolerably good partial resemblance, still it differs materially." Healso notes points of resemblance to ferns of other genera, and ends by saying, "In fine, when hereafter discovered in fruit, I have little doubts of its belonging to one of the four genera, Pteris, Lomaria, Nephrolepis, or Gymnogramma." To me and others it appears to be a common form of Pteris cretica, and as that fern is found in Southern Europe, great part of Asia, Australia, and Polynesia it would be by no ineans unlikely to occur in New Zealand, particularly in the hot-spring region. If so, fertile fronds should be of the form shown in figure No. 4 a of the same plate. It seems curious, however, that the fern should not have been gathered again, as $\mathrm{Mr}$. Colenso mentions having several times written to residents in the neighbourhood, asking them to try and get him further specimens, and in a letter to myself he said he had even offered a reward for them. This shows how little notice is taken, by travellers, of things immediately arourd them, since a coach has run regularly for years through the locality where the fern was gathered, and it probably grows beside some steep incline where passengers are accustomed to get out and walk. Fern-collectors visiting the locality should look for it; as specimens would be highly welcome to other collectors or to Museums.

\title{
SUB-GENUS PESIA. (Pee-ze-a.)
}

Has creeping rhizomes, and involucres more or less distinctly double. We have two plants of this sub-genus.

\author{
PTERIS AQUILINA. (Pter-ris ak-wil-i-na.) \\ "BRACKEN," "BRAKE." MAORI NAMES "RARAUHE" AND "RAURAU." \\ PLATE XIV., Nos. 1 and 1a.
}

This is the common fern which still covers large tracts of land in the Colony, and formerly clothed a far larger portion, particularly near the sea-coast. It is botanically 
known as variety "esculenta" or "edulis," because its rhizomes are full of starch, like arrowroot (I have known it used instead of arrowroot by a doctor), and formerly under the names of "aruhe," "erau " or "roi," constituted an important item of Maori food. These widely-creeping rhizomes are generally about as thick as a man's little finger, and in ordinary soils contain a good deal of woody fibre mixed with the starch, but in rich land, particularly near the margins of bush, there is often scarcely any fibre at all, and the rhizome, when roasted in the embers and peeled, is not unlike captain's biscuit in substance and flavour, but slightly bitter. The skin is dark brown. The fronds spring up singly, a few inches asunder. The stipes is tall, erect, stiff, brown and shining, and channelled on the upper side. When cut through, the section of the woody fibre within it is seen to be arranged in a figure which the ancients fancied was like an eagle (aquila) just raising its wings to fly, and so gave the name "aquilina" to the fern. Country labourers in the south-west of England profess to see, in the same figure, a representation of King Charles in the oak tree. The rachis and costæ are similar to the stipes, but the latter shade gradually into the hue of the foliage. Frond broadly triangular, bi or tri and occasionally quadri-pinnate in very large fronds, which are sometimes, with the stipes, as much as fourteen feet high, near the margins of bush. Pinnæ stalked, broad and spreading, and divided into long linear ultimate lobes or segments. When the fronds first expand, a sweet gum exudes from little knots or buds in the axils. Sori narrowly linear, sub-marginal, and occupying nearly the whole of the under-surface of the segments. Texture harshly coriaceous. Colour brownish green. Very young plants are far prettier than older ones. They are more or less tufted, the foliage is broad and almost membranaceous and the colour a bright green. The stipes is shorter, and the frond bi-pinnate and oblong, with broad and lobed pinnules. Plants sometimes retain the oblong frond for a considerable period; in fact, till long after the foliage has assumed its permanent narrow linear character. I have seen fronds three feet long by only six or eight inches broad, and at first thought they indicated a distinct variety of the fern, but I found that after a time the plants produced fronds of the ordinary type. In some cases they were several years old before they did so. This fern is found apparently all over the Southern Hemisphere, just as the normal Pteris aquilina occurs throughout the northern one. It is found in the North Island up to 3000 or 4000 feet; but seems not to ascend so high farther south. Though so common and hardy, it is not easy to cultivate. When its rhizomes are enclosed in the sods used in building a fence, they produce fronds readily enough, but if potted they are almost sure to die. Seedlings come up abundantly on faces of side-cuttings, in pots, in ferneries and greenhouses, in caves and gravel-pits, and, in fact, in all sorts of situations; yet if moved into pots, or even shifted from a small pot into a larger one, they almost always die. The plant evidently likes to have its own way, and objects to being petted. 


\section{PTERIS SCABERULA. (Pter-ris sca-ber-ru-la).}

PLATE XIX., No. 5.

This fern is abundant throughout the Colony, and is generally about the first to grow on the faces of landslips and side-cuttings. It seems confined to New Zealand and the Chatham Islands. It has a widely-creeping, brown, scaly or velvety rhizome, from which fronds spring at short distances. Stipes generally about half as long as the frond, erect, moderately stout, reddish or yellowish brown, sometimes smooth and glossy, and sometimes velvety. Rachis and costæ the same, the former often slightly zigzagged. Fronds lanceolate or oblong, bi or tri-pinnate, Pinnæ stalked and cut into very numerous small oblong or lanceolate ultimate segments. Sori submarginal, yellowish brown, and almost covering the undersides of the segments. Involucres formed by reflexed margin and soon covered by the capsules. Texture harshly coriaceous. Colour bright yellowish green. Height seldom more than two and a half feet.

This is one of the prettiest of New Zealand ferns, and very useful for bouquets, as its lacelike sub-division makes it show to advantage, while at the same time its wiry texture keeps it from drooping. It varies however a good deal in the delicacy of its foliage in different localities. Near Wanganui, I have gathered it most minutely divided and lacelike, while at Auckland I saw specimens which were so coarse and broad, both in their form and in their segments, that at first I took them for Nephrodium velutinum. It is a very easy fern to cultivate, but likes plenty of potroom; in fact, it so soon overgrows a pot that it is best always to have a young plant or two coming forward, to replace those which have become too large for pot-culture. It is best to take up seedlings with a good ball of earth attached to them, as the fronds of small plants are more numerous and more delicate than those of large ones. It grows best in rather poor sandy loam or alluvium.

\section{SUB-GENUS LITOBROCHIA. (Li-to-bro-ke-a.)}

Has the veins anastomosing, with free included veinlets. Rhizomes sometimes erect sometimes creeping. Foliage broad.

\section{PTERIS MACILENTA. (Pter-ris mas-sil-len-ta.)} PLATE VII., No. 1.

This is a favourite plant with fern-growers, as its dark yet bright green colour, and distinct leaf-like pinnules, are very striking. It is confined to New Zealand. It has a stout erect rhizome, and a crown of rather numerous fronds, which are sometimes five feet high. The stipes is about as long as the frond itself, and like the rachis and costæ, yellow or light brown, stiff, erect and glossy. Frond bi to quadri-pinnate and triangular. Pinnæ consisting merely of costæ and the leaf-like pinnules. Pinnules stalked, oval, deltoid, rhomboidal, or like parallelograms with two obtuse and two 
acute angles. The terminal ones are generally larger than the others, and usually cut into deep lobes, which have slightly indented or toothed edges. Sori sub-marginal, but usually placed in the hollows between the lobes, and stopping short of the ends, yellow or light brown. Involucres formed of altered margin, and soon hidden by the capsules. Colour rather dark bright green; texture coriaceous and glossy. This fern is common all down the West Coast of the North Island, but seems less so on the Eastern seaboard. It is confined to valleys, and is more frequently met with near the coast than farther inland, not ascending to any great height above the sea-level. The pinnules vary greatly in size as well as in shape, the more branched the frond the smaller are the pinnules in proportion, and the handsomer the plant in consequence. I have seen them sometimes nearly as broad as long, while at others the length is four or five times the breadth. It is very scarce in the Middle Island, being only reported from the Grey Valley by Sir Julius Von Haast, and is said to occur at Banks's Peninsula by Mr. G. M Thompson; though I do not see it in any published list of Canterbury ferns which I possess, and know that Christchurch florists are glad to import plants from the North Island. It is also called Litobrochia macilenta. A very pretty dwarf form, which I have heard call "variety minor," is found at Turakina, and from its having received a distinguishing title, it probably occurs elsewhere, though I have not heard of it from any other locality. It never grows above a foot or fifteen inches high, and has small oval pinnules. It also propagates itself by dividing into several crowns, which the normal form does not. All forms are easily cultivated in sandy soil and leaf-mould, and do best in the shade, though not absolutely requiring it.

\section{PTERIS COMANS. (Pter-ris co-mans.) \\ PLATE XXIV., No. I.}

This fern, in its typical form, seems only to occur from about Auckland northward and to be confined exclusively to the immediate vicinity of the sea. In its general character it resembles the preceding one, but is less divided, being seldom, if ever, more than bi-pinnate. The pinnules are not stalked, but sessile, though the lower ones are only narrowly so. It seems to vary much in size and texture. All the plants which I have seen were much smaller than Pt. macilenta, with far lighter colour and more coriaceous texture, sometimes almost fleshy; while Mrs. Jones distinguishes it from Pt. macilenta by "its larger size and darker colour," and Mr. G. M. Thornson describes it as "membranous and flaccid." I fancy the latter is a mistake, arising from some plants of Pt. macilenta, which I saw in Dunedin, being mis-named Pt. comans. The fact is that the two plants are so connected by intermediate links, that I greatly doubt whether they ought not to be classed merely as two forms of one fern. I have myself gathered fronds, about twenty miles up the Wanganui River, which I should unhesitatingly have pronounced to be Pt. comans if I had seen them at 
Auckland, even the thick fleshy texture being present in a modified degree, while the light green colour seemed to remove them at once from Pt. macilenta. It is just one of those cases where the connecting links are puzzling, though the extreme forms are very widely different. Another form of Pteris comans, known as "variety Endlicheriana," occurs on some of the islands in the Hauraki Gulf, and is even less divided and more sessile in its parts (even its pinnæ being sessile) than the typical plant: yet there is a continuous series of forms from it to the quadri-pinnate Pt. macilenta, with small leaflike pinnules, of the Wanganui valley and elsewhere.

Pteris comans is easily cultivated; in soil similar to that suited to Pt. macilenta, but grows very slowly. My own plant has been in my possession for six years, and is, I believe, fully twenty years old, and does not yet produce fronds eighteen inches long, while seedlings of Pt. macilenta will grow five feet high in about three years. This makes me think the former a dwarfed littoral form of the latter. It is also called Pteris Endlicheriana, Pteris micropteris, and Litobrochia comans, and occurs in Australia, some of the Polynesian Islands and Juan Fernandez, as well as in New Zealand.

\section{PTERIS INCISA. (Pter-ris in-si-sa.) MAORI NAME "MATUA RARAUHE." PLATE VIII., No. 4.}

This very handsome fern is found over a very large portion of the giobe extending from Southern Asia southward through Africa to the Cape of Good Hope, through Australia, Polynesia and New Zealand to the Auckland Islands, and from the West Indies and Isthmus of Panama through the greater part of South America. As might therefore be expected, it has been called by a variety of names, such as Pt. montana, Pt. vespertilionis, Pt. Brunoniana, and Litobrochia vespertilionis. It also varies in form in these countries, though in New Zealand it keeps pretty well to one type, only varying a little in the shape of its fronds, and the fulness and texture of its foliage, according to the situation in which it grows. It occurs in all sorts of places, in swamps, in open bush, on ridges, on rotten logs, among rocks, and on hill sides; but I have never seen it in dense bush, though it often appears beside a road cut through such a bush, or in a clearing within it. It occasionally attains a height of seven feet, and often of five feet, but I have never seen it so luxuriant anywhere as in the immediate vicinity of boiling-springs, where its roots seem to take no harm from the heat of the water. Its rhizome is smooth, stout, and creeping, and produces numerous fronds. Stipes stiff, erect, shining, yellow or light brown, varying in length, but generally about half as long as the frond. Rachis similar in colour and texture. Frond varying from broadly triangular to oblong or ovate lanceolate, bi or tri-pinnate. Colour bright pea green : texture sub-coriaceous, but sometimes thinner than at others. Pinnæ stalked, but furnished with pinnules so completely to the base as to appear 
sessile, deltoid, oblong or lanceolate. Pinnules deeply cut into lobes, which, when barren, are broadly oval, but when fertile narrowly tapering and pointed. Sori generally extending to the ends of the lobes, but sometimes broken into detached lengths. Involucres formed of reflexed margin, and so broad as seldom to be hidden by the capsules. Texture thinly coriaceous and shining; under side of pinnules often whitish or greyish. I have met with this fern certainly up to 3000 feet above the sea level.

It is not easy to grow this fern from the rhizomes, as, like those of Pteris aquilina, they seem to have a difficulty in again taking hold of the ground when once detached from it. It sheds its spores so abundantly, however, that there is never any difficulty in procuring seedling plants where it occurs, and if these are taken up with a lump of the soil or other material in which they are growing, and planted in sandy loam and leafmould, they will increase in size very rapidly. The rhizomes should be watched, to prevent their climbing over the edge of the pot; and any which indicate an intention of doing so should be carefully bent, and pegged down, so as to guide them round the inside of the pot; with a view to which, it is well to keep the top surface of the mould an inch or more below the edge of the pot. By a little care in this way, and occasional shifting into a larger pot, a fine mass of foliage can be produced in a few months, and its peculiar pea-green colour is very pleasing to the eye.

\section{PTERIS (NEW SPECIES.) \\ PLATE XXVIII., No. 2.}

The frond shewn in the plate is one which I lately saw in the possession of my nephew, Mr. D. H. Monro, of Christchurch, who obtained it from a toll-gate keeper at the Otairi Gorge, (usually incorrectly spelt Otira) who collected and pressed ferns for sale to travellers. As I understand that the man has ceased to keep the toll-gate, I cannot ascertain whether the plant has an erect or a creeping rhizome, or what was the original length of the stipes. The stipes and rachis are shining reddish brown, the latter shading to straw-colour towards the top, and they are channelled in front. The costæ are also brown, shading to straw-colour. The frond is long, lanceolate. The pinnæ are arranged in pairs, and ascend slightly. The first three pairs are shortly stalked, the next pair narrowly sessile, and the others broadly sessile and slightly decurrent on the lower side. The lowest pair are pinnate on the lower side, and pinnatifid on the upper, the next two pairs pinnate on both sides, and the others pinnatifid, or more or less deeply lobed. The texture is rather harshly coriaceous, with indistinct anastomosing veins; a rather stout nerve shewing all along the outer edges on the upper side, and connecting the veins. The colour has apparently been yellowish green, and the upper surface extremely glossy. The sori are continuous, the capsules shewing from beneath a rather wide involucre, formed of the reflexed margin.

The fern is certainly new as a New Zealand plant, and I can find no description 
in the Synopsis filicum which suits it. As will be seen, by reference to the plate, it bears a certain amount of resemblance to Pteris incisa, and, but for its having fully developed sori, it might be supposed to be a young Alpine form of that fern. The fructification, however, proves the frond to be from an adult plant. It may prove to be a dwarf form of Pt. incisa, stunted through growing at a very high level, but should be sought for by any collector visiting the Otairi Gorge. Should it prove to be new to science, I would propose to call it "Pteris alpina."

\section{GENUS LOMARIA. Lo-ma-re-a.}

Has sori linear and continuous, parallel with the midrib, and occupying all, or nearly all, the space between it and the margin. Involucre membranous, formed of revolute edge of frond. Fronds dimorphous (that is having the barren and fertile fronds different) usually once pinnate or pinnatifid, rarely simple or bi-pinnate. Veins free. In the northern part of the Colony, the Maoris call the large plants of this class by the general name "Uruuru-whenua."

\section{SUB-GENUS EULOMARIA.}

Has the base of the frond not suddenly dilated, glandular. Ring of capsules vertical. The following have their fronds simple, pinnatifid, or very occasionally pinnate below, with bases of pinnæ dilated. Pinnæ few.

\section{LOMARIA PATERSONI. (Lo-ma-re-a Pat-ter-son-i.) \\ PLATE XI., Nos. 3, 3a, and $3 b$.}

Has its rhizome short, stout, creeping or sub-erect, and scaly; sending out more slender lateral ones, which produce fresh crowns with stout rhizomes. Stipes short, stout, usually naked in small simple fronds, but widening out into wings or auricles, or both, in larger ones; dark brown or black, and often with scales at the base. Rachis dark-coloured, shading into the hue of the frond. The fronds are of two classes. Small barren fronds are generally simple, and either broadly oval or lanceolate, but sometimes have an auricle or two at their bases. Larger ones, which are sometimes as much as three feet long, are deeply pinnatifid, and vary in shape from lanceolate to oblong acuminate. They have a broad web along the centre, from which the lateral segments or lobes spring. These are entire, broad below, and either tapering or oblongacuminate: the colour of the whole being of a very dark shining green above, and rather lighter below; and the texture harshly coriaceous, and so brittle as to make the fronds difficult to press, the wavy edges breaking. Veins forked, free, and very distinct. The fertile fronds vary similarly in shape, but are usually longer than the barren ones. The central web becomes very narrow or obsolete, and the pinnæ which are not more than a quarter of an inch broad, are very decurrent below, and covered by the sori, 
except a very narrow stripe along the centre of each. Sori linear. Involucres formed of reflexed margin of the frond, and soon hidden by the sori.

This fern is found in India, and thence southward and eastward to the Fijis, Australia; Tasmania and New Zealand. It would appear as if only the simple form of frond was known in most of the above localities; as for a long time, it and the pinnatifid form, which was called "Lomaria elongata," were supposed to be distinct ferns, though in Fiji and New Zealand, both kinds are constantly found on the same plant. The fern is found throughout the North Island, or at all events as far north as the neighbourhood of Auckland, from a few feet above the sea-level to certainly 2000 feet elevation. It is also plentiful on the West Coast of the Middle Island, though scarcer on the Eastern side, where it occurs at all events as far south as Dunedin. It only occurs in very damp shady places, and often in quite boggy ones, so that if it planted in rich vegetable mould you can hardly give it too much water. It will not bear much drought, however, and I have seen large patches of it die if a road were opened past them, or if the adjacent ground was cleared. It often occurs on faces of dripping cliffs. It is also called L. elongata, L. Colensoi, L. Heterophylla, L. Cumingiana, and L. punctata.

\section{LOMARIA VULCANICA. (Lo-ma-re-a vul-can-ik-a).}

CONFOUNDED WITH L. PROCERA BY THE MAORIS AND CALLED "KOROKIO."

PLATE XXVII., Nos, 5 and $5 \mathrm{a}$.

This fern has a very stout, erect, scaly caudex, producing a crown of few fronds. The stipes is rather long, erect, and somewhat scaly at the base; usually brown and woody. Rachis also brown, shading to colour of frond. Frond more or less broadly triangular, and pinnatifid. The pinnæ of the barren frond broad, oblong-acuminate, or tapering, and widened at the base : the lowest ones being bent downwards and outwards. Colour dark olive-green; texture coriaceous. The fertile fronds are much longer than the barren ones, and usually narrower in proportion to their length. Their pinnæ are very narrow, with a small leafy base to each, and some distance asunder. The surfaces and margin are said to be sometimes slightly hairy, but I never saw them so myself. It is also called "L. filosa," L. deflexa," and " $L$. deltoides."

This is quite a sub-alpine fern. I have never seen it growing at a lower level than about 2000 feet above the sea in the North Island, though it may possibly descend lower farther south. It mostly occurs in rather open bush (usually birch bush), but I have seen it growing in almost open ground near the base of Ruapehu. The late Mr. Potts described it as common on Banks's Peninsula, and the Malvern Hills, Canterbury; but, unless in those places, it seems to be nowhere abundant, though it has been met with nearly from end to end of the Colony. It grows also in Java, Tasmania, and the Pacific Islands. It is easily cultivated in sandy loam, mixed with leaf-mould. 
A second class is called the "attenuata group," and is characterised by having ample ovate fronds with many pinnæ. The following New Zealand ferns belong to it :

\section{LOMARIA DISCOLOR. (Lo-ma-re-a dis-col-or). \\ MAORI NAME "PIUPIU." \\ PLATE IV., Nos. 2 and 2 a.}

This fern has thick creeping rhizomes ramifying over large spaces of ground, and sending up caudices two to three feet high, crowned with numerous fronds. The stipes is short, stout, and of a shining light brown or straw colour, but furnished with narrow scales at the base. The barren fronds are broad, and taper to both ends. They are very deeply cut into numerous alternate, rather narrow, tapering pinnæ or lobes. The texture is coriaceous, and the colour of the upper side bright glossy green. That of the under side varies from almost white to reddish brown, on which the veins show very distinctly. It is this double colouring of the fronds from which the plant takes its name. The barren fronds form an outer ring leaning outwards, and the fertile ones stand erect within it. These are about the same length as the barren ones, but not so wide, the pinnæ being short and narrow, but with large leafy bases. The sori are linear and sub-marginal, covering the under-surface of the narrowed part of the pinnæ. Involucres narrowly marginal and hidden by the sori.

This fern is abundant all through the Colony and the adjacent islands, from Norfolk Island to the Auckland Islands, and it also grows in Australia. It is found in both heavy and light bush, sometimes almost in the open plain, and will hold its ground for several years, even when the bush is cleared. It seems, however, to prefer dry, or at all events well-drained land, and not to grow in very wet soil. It is easily cultivated in sandy loam and leaf-mould, but is best moved when young, as it grows pretty rapidly. I have seen a very beautiful bi-pinnatifid form of it; the pinnæe of the barren fronds being deeply cut into pointed lobes. The plant, however, produces no fertile fronds. I also lately saw a form, found near Stratford, in the Taranaki Provincial District, which has the stipes nearly, or quite, as long as the frond.

\section{LOMARIA PAUCIJUGA. (Lo-ma-re-a Pau-se-ju-ga). PLATE XXIX., No. 6.}

In Volume XX, of the Philosophical Transactions, page 222, the Rev. W. Colenso describes, under the above name, a fern which appears to be new. It was found in I 887 , on the side of Tongariro, by Messrs. Owen and Hill, who sent the specimen to Mr. Colenso. The following is the description, from which the drawing is made:

"Plant small : caudex (specimen, a top broken off) ascending, one inch long, hard and woody, as thick as a common lead-pencil, with several old stipites and scales on it below the living fronds. Fronds (four, all sterile) sub-opposite, or tufted, erect, equal, uniform; lamina herbaceous, olive-green, ovate, sub-acuminate, three inches long, 
one and half inches broad, pinnatifid; lobes four to five pairs, short, opposite, oblong, nine lines long, five lines broad, very obtuse, spreading, rugulose, close and slightly overlapping, glabrous (not glossy) on upper surface, largely and finely pilose on under surface and on rachis; hairs hyaline, jointed, margined, puckered, much veined, veins conspicuous, much branched, extending to margin, clavate, red; margins white, cartilaginous and recurved, undulate and slightly crenulate, denticulate, closely ciliate; the lowest pair of lobes cut nearly to rachis, and shorter than the pair above them, and much broader in the lower basal portion, which is cordate sub-auricled and divergent; the upper lobes cut about half way to rachis: the terminal lobe large, broad, sub-ovate-acuminate, the base once crenately lobed, tip truncate. Stipes three inches long, channelled (also rachis), flexuous; the upper part very slender, almost filiform, straw-coloured, finely hairy, hairs patent; the lower portion much compressed, flat, dark brown, subscaberulous. Scales subulate lanceolate, much acuminate, three-quarter inches long, red brown, glossy, finely striate: margins slightly and distinctly denticulate; cells numerous, linear-oblong."

Mr. Colenso says, "It is scarcely allied to any known New Zealand, Australian, or Polynesian species. In its soft herbaceous character it approaches L. nigra; in its pilose character (slightly) L. vulcanica; in the position and shape of its lobes (but again only very slightly) L. discolor. Unfortunately, a fruitful frond has not been seen, and my only specimen appears to have been broken off at some distance above the ground, being quite clean and free from earthly particles." In a letter to myself, he says he has in vain offered a reward for a fertile frond. Anyone visiting Tongariro should seek for the plant, which I have drawn from the description; but which I think may prove to be a stunted Alpine form of $\mathrm{L}$. discolor, taken from a very young plant, as I have seen somewhat similar fronds of that fern from near Mount Egmont, with equally long stipites.

\section{LOMARIA ATTENUATA. (Lo-ma-re-a At-ten-u-a-ta.)}

This fern is pretty widely spread throughout the Southern Hemisphere, being found in Africa from the Gulf of Guinea to the Cape, in America from the West Indies and Guatemala to Brazil and Juan Fernandez, in the Mauritius and neighbouring islands, in Polynesia, and at Norfolk Island. The northern part of New Zealand seems to mark its southern limit at this part of the Globe, as it is only reported from the Little Barrier Island, in the Hauraki Gulf, where it was gathered by Herr Reischek, the German naturalist ; and yet from its similarity to other N.Z. Lomarias, it may very possibly occur elsewhere, but have escaped notice. It has a long horizontal rhizome densely clothed at the end with narrow bright brown scales. The fronds form crowns, the fertile pinnæ standing erect within the barren ones. The stipes is short, erect, slightly scaly at base but naked above. Rachis also naked. Frond broadly ovate 
with pointed ends, like that of L. discolor, and narrowing very gradually downwards, pinnatipartite. The pinnæ of the barren frond are numerous, alternate, longer and narrower than those of $\mathrm{L}$. discolor, widened at their base, and bluntly serrated towards their ends. They are also slightly falcate and slope more upwards. Texture coriaceous; colour bright green on both sides : veins well defined. Sometimes there are no pinnæ, and the shape of the frond is entire and lanceolate, like that of small L. Patersoni. The pinnæ of the fertile frond are as numerous as those of the barren frond, though the frond itself is smaller. They are long and extremely narrow, like those of L. lanceolata, the sori covering all but the costæ. As Herr Reischek has sent home his specimens, I could not borrow them to show them on a plate, and my own Australian plant is too young to produce fertile fronds; but the fern may be at once identified by its barren fronds resembling those of Lomaria discolor, but with narrower and more numerous pinnæ, and both surfaces green; and its fertile ones being like those of $\mathrm{L}$. lanceolata with far more numerous and longer pinnæ.

A third class is called "the Spicant Group," and is distinguished by having sinaller, narrower, more lanceolate fronds. The following plants belong to it :

\section{LOMARIA LANCEOLATA. (Lo-ma-ri-a Lan-ce-o-la-ta.)}

PLATE XI., Nos. 2 and $2 a$.

This is probably the most abundant of all the N.Z. Lomarias, except L. procera, as it occurs from end to end of the coloriy, as well as in the Southern Polynesian islands, Australia, Tasmania, and the Chatham, Campbell, and Auckland islands. A closely allied form also occurs in Chili; and I can see little to distinguish it from the European L. spicant. The rhizome is stout and erect, sometimes rising into a short caudex. The fronds form a crown, the barren ones being outside, and the fertile ones standing more erect within them. The stipes is short, erect, dark coloured, with some darker scales at the base, but smooth above. Rachis smooth. Sterile fronds lanceolate, narrowing gradually below, and cut right down the rachis into falcate pinnæ, which slope slightly upwards, and have their edges sometimes entire, and sometimes slightly indented or toothed. Texture almost membranous, showing the venation very clearly; colour varying from bright to dark green. Pinnæ of fertile fronds about oné-sixteenth of an inch wide. Sori linear, covering the pinnæ, or leaving only the costæ visible.

This fern may be found on almost any shady bank, and often occurs in almost dry situations under overhanging ledges. I have found it growing in crevices of rock, particularly of shell-rock; and in such cases have noticed that the young fronds are often yellow, red, or light purple, with the veins showing in a darker tint. The fertile fronds also assume the same colours, and the whole plant looks extremely lovely. Such plants, however, when transplanted, produce fronds of the ordinary colours; 
showing that the tints are caused merely by the conditions under which the ferns grow. This fern varies somewhat in the form of its fronds, being sometimes far narrower than at others. At Auckland, too, I saw many plants with narrow fronds, and very large terminal pinnæ to the barren ones; and I observe that Mr. Thomson says it often has a trunk one foot to two feet high; though I have never seen one more than three inches. I have occasionally seen the stipes forked, so as to produce two fronds. The plant is very easy to cultivate, preferring sandy loam and leaf-mould, with a moderate amount of shade, rather than moisture to the roots.

\section{LOMARIA AGGREGATA (Lo-ma-re-a Ag-gre-ga-ta) \\ PLATE XXIX., Nos. 7 and 7a.}

A small fern is described, under this name, by the Rev. W. Colenso, at page 223 of Vol. XX of the Philosophical Transactions, as growing by the sides of streams and watercourses in low gullies near Dannevirke, Hawke's Bay. It is described as "closely and naturally allied to L. lanceolata, L. membranacea, L. pumila, L. oligoneuron, and L. intermedia ; and yet as differing from all in several respects, but forming with them a kind of natural sequence." The Revd. gentleman adds, "At the same time, with Sir W J. Hooker, I feel obliged to remark on the great and increasing difficulty or impossibility of making real distinctions and differences in allied ferns clearly known without accurate drawings." Yet after saying this, and admitting that it is difficult to distinguish the plant from L. lanceolata, his description is unaccompanied by a drawing. The following is the description: "Rhizome (underground) long, two or three inches or more, narrow, woody. Rootstock (above ground) one to two inches, with many stipites, and numerous blackish subulate scales: rootlets brown, long, fibrous, hairy, much branched; several perfect plants growing in separate tufts or heads from one root-stock. Plant small, tufted; fronds erect, spreading, four to six inches high, linear-lanceolate, pinnate, membranaceous, glabrous, green inclining to pale; stipes various lengths, half an inch to one inch (sometimes but rarely three inches), very slender, channelled, minutely and thickly papillose, reddish brown, scaly below at bases: sterile frond three to five inches long, six to nine lines wide, pinnatopinnatifid, the green lamina completely severed to rachis (merely the extremely narrow white, sub-cartilaginous translucent margin remaining, and so throughout); segments alternate, sometimes opposite, free but close, sinuses broad, broadly oblong, (sometimes broadly deltoid the upper margin horizontal, and apex very obtuse), two to four lines long, sessile with a broad base extended upwards and decurrent, tips rounded; the lower segments small and semiorbicular, sometimes narrow lunate; the terminal lobe ovate obtuse; margins entire, slightly sinuate, narrowly cartilaginous, minutely and sharply serrulate (sub lente) at tips of veins with 2-3-4 microscopical teeth close together; mid-rib not extending to tips; veins few pinnate, 4-5 jugate, 
simple and forked, extending to margins, slightly clavate: fertile frond two inches shorter and narrower, the stipe usually longer, pinnæ few, alternate and opposite, two to three lines long, narrow linear, much falcate or curved upwards, distant, sessile, and largely decurrent on rachis; tips obtuse and mucronate; the ultimate lobe long and very narrow. Involucre narrow, not extending to tips, at first incurved, afterwards recurved and everted, margin entire. Sori brown profuse, covering mid-rib and rachis also when lobes opposite."

Now, the meaning of the whole of the above (as my readers will see by the figures which I have drawn from it) is that Mr. Colenso found some plants of Lomaria lanceolata, the caudices of which divided into several crowns, and whose barren fronds were a little narrower, and had shorter, straighter lobes than usual. The strength of the plant being divided among several crowns, instead of supporting only one, depauperation was bound to ensue. Curiously enough, when I had made the drawing, and then went to compare it with a plant of Lomaria lanceolata in one of my own cases, and see in what the differences consisted, I found that my own fern was similarly parting into separate crowns; so that the only apparent real distinction vanished. My plant is an accidental seedling, which came up in my greenhouse; so that I do not know from whence the spore originated. I have no doubt, however, that branching plants of L. lanceolata occur near Wanganui; though I never noticed them, because the fern is so common that one pays no heed to it, unless when some particular brilliancy of colour in the young frond attracts attertion.

\section{LOMARIA DURA. (Lo-ma-re-a du-ra.)}

\section{PLATE X., Nos. 4 and 4 a.}

This fern only occurs in very exposed situations, close to the sea coast, towards the south end of the Middle Island, say from about Lyttelton southwards, as well as at the Sounds, and thence to the Auckland Islands ; and also at the Chatham Islands, to which it was for some time supposed to be peculiar. In its general growth it is very much like L. lanceolata, but the rhizome develops nore frequently into a caudex, and the texture is very thick, in fact almost fleshy. The fronds are also widest about two-thirds of the way up, and are blunter at top and more gradually tapering below. Sometimes the apex is ovate, with a long projecting terminal pinna. The pinnæ of the fertile fronds are also much closer together, wider, and thicker than those of $\mathrm{L}$. lanceolata; so that they may even be said to be crowded. It is an easy fern to cultivate, as I have seen it growing, without any shelter, in the Botanical Gardens at Christchurch; but it would probably be none the worse for an occasional spraying with salt water, and a little of the same applied to the soil in which it grows. It probably does not need rich soil. Is also called "L. rigida." 


\section{LOMARIA BANKSIl. (Lo-ma-re-a Banks-e-i.) \\ PLATE XXVI., Nos, 2 and $2 a$.}

This is another sea-side fern, but occurs in less exposed situations than the last. It is found, however, in caves among the rocks, near Wellington, where it is often soaked with the salt spray in rough weather, and takes no harm. It seems peculiar to New Zealand, where it is found at intervals from end to end of the Colony, but seems nowhere very abundant. The rhizome is short, thick, fibrous, and has dark reddish scales towards the top. It is sometimes prostrite and sometimes erect, and often sends out crowns from its sides. The stipes is short, erect, black or dark brown, scaly at base, smooth above. Rachis also smoth. Frond oblong or lanceolate, and divided into long lobes or pinnæ which are sometimes shortly oblong with rounded ends, and sometimes almost circular; but are always joined to the rachis by a broad base. There seem to be no separate fertile fronds, but the fertile pinnæ are placed towards the apex of what are otherivise barren fronds, sometimes extending through nearly the whole length. These fertile pinnæ are much narrower than the barren ones, but still are wider, in proportion to their length, than those of any other fern in this group. The texture is coriaceous; colour bluish green, and veins distinctly visible. It grows freely in cultivation, but requires shade and moisture, and is the better for being watered with a little salt-water occasionally.

\section{LOMARIA ALPINA. (Lo-ma-re-a al-pi-na.) \\ PLATE XVII., Nos. 5 and 5 a.}

This fern has slender rhizomes covered with reddish or blackish scales, and ereeping in all directions, so as to form quite a mat. Crowns of a few fronds each spring from these at short intervals, some of the fronds being barren and some fertile. The stipites of the barren fronds are generally about as long as the fronds themselves, stiff, slender, erect, brown or reddish, smooth, or very slightly scaly. The barren fronds are very narrowly oblong, and divided into a number of short bluntly-pointed pinnæ, with broad unwidened bases, and entire or slightly toothed edges. The texture harshly coriaceous; colour dark olive-green, and veins rather distinct. The fertile fronds have the stipes much longer than the barren ones, and the fronds themselves are generally somewhat longer. The pinnæ are broad at the base, giving them the appearance of being decurrent on the upper side, but narrow rapidly, and are set downwards and outwards. Sori nearly covering the pinnæ. As its name implies, this fern is usually found at high levels, and yet it is occasionally met with only a few feet above the sea. I have seen it growing in pretty dense bush, and also among manuka scrub, and on open grassy plains. It is very easily cultivated, and soon overspreads a considerable space. It is liable to the objection, however, that the original root-stock, and the crowns adjacent to it, are apt to die out, so that the whole plant forms a ring 
with a bare patch within it, instead of a mat of fronds. From this cause, it often needs to be divided and repotted, or it will be lost altogether.

A somewhat thinner, or more membranous-textured form (Plate XXIX, No. 8) was found at Akaroa, between 1840 and 1843 , by $M$. Raoul of the French Frigate L'Aube, and was called by him "Lomaria pumila." This find has been a source of great bewilderment to New Zealand botanists. The plant was supposed to have been destroyed through the clearing of the bush where it grew, and it was said that the only living example of it was in Kew Gardens. As I had found at Wanganui a plant which seemed to answer its description, though I was perfectly certain that it was only L. Alpina, I wrote to Mr. J. G. Baker of the Royal Herbarium at Kew, who kindly sent me fronds of the fern in the Gardens there, when I found that it exactly tallied with my own find. About four years ago, however, the question was set at rest by the late Mr. Potts, of Christchurch, who found that Raoul's plant still survived in the very locality where he had gathered it, so that there is now no doubt at all about the matter. M. Raoul evidently did not know L. alpina, and so called what he found by the other name, and his description of it, as being thin in texture, prevented its being recognised as merely a plant of the well-known fern. At one time it was supposed that what he had found was "L. membranacea," and that he had made the mistake of assigning a creeping rhizome to it ; but that fern seems not to occur in the Canterbury District, and, therefore, M. Raoul could not have found it. The only differences are, rather more lanceolate barren fronds, thinner texture, and barren pinnæ decurrent on upper side. Another form of L. alpina has the lower pinnæ quite distinct from each other, and all of them slightly narrowed or hollowed on both sides, towards their base. It occurs on the Nelson mountains and in Chili, and has been called "L. Germainii." The separation of its pinnæ has caused it to be included in another group in the Synopsis. I had the plant, however, in cultivation for some years, so that I have no doubt as to its being only a form of L. alpina. The mistake, no doubt, arose from its being classed from dried fronds only, instead of from living plants. L. alpina has also been called L. Linearis, Stegania alpina, and Polypodium penna-marina by different botanists, as it occurs in South America, Australia, Tasmania, and the Chatham Islands:

\section{LOMARIA PARVIFOLIA. (Lo-ma-re-a par-vif-o-lea). PLATE XXV., No. 5.}

The fern which the Rev. Mr. Colenso has described under this name, at page 224, Volume XX of the Philosophical Transactions, from some barren fronds brought to him from Tongariro, in 1887 , by Mr. Hill, is figured from his description as above. It would be quite useless to reprint the description, which occupies nearly half a page of the Transactions, because the fronds are evidently examples of the thin form of L. Alpina, which M. Raoul called L. pumila, somewhat elongated, probably through 
growing among moss or other low vegetation, and they have intended to be fertile but failed in the attempt. The fronds, and particularly the lower lobes have assumed the fertile form, but have not developed their sori, while the upper ones still retain their barren shape. It is not at all unusual for fronds of L. Alpina to be partly barren and partly fertile, though in such cases the fertile lobes are usually in the upper part, and the barren ones in the lower part of the frond. I cannot at all understand Mr. Colenso's not seeing at once what the fronds were, unless he has not had much experience of L. Alpina.

Another group is distinguished by having the lower and middle pinnæ of the barren frond narrowed at the base, and distinctly separated from each other. The following belong to it :

\section{LOMARIA PROCERA. (Lo-ma-re-a pro-cer-a.) \\ MAORI NAME "KOROKIO." \\ PLATE II., Nos. 1 and 1a.}

This is certainly the most common of the Lomarias in New Zealand, if it is not the most common fern of any description in the Colony. It makes its appearance wherever there is a little shade, even though there be but little moisture. It is used by the Maoris to cover the food in their "hangis," or cooking-pits. Its forms are so numerous and variable as to make it almost impossible to describe it satisfactorily. The rhizome is short, thick, hard, scaly, sometimes erect, and sometimes sub-prostrate. Stipes usually erect, stiff, scaly at base, and varying in colour from yellow to black. Rachis the same. Fronds pinnate, varying in length from a few inches to ten feet; and in form from lanceolate to oblong. The largest fronds are generally found hanging on the faces of wet cliffs in shady places. Pinnæ varying in numbers from three pairs to more than twenty, and in shape (the barren ones) from narrowly lanceolate to oblong. They are sometimes acutely pointed and sometimes rounded at the ends. Sometimes they are broadly auricled at the base, the auricles more or less surrounding the rachis. The lower ones are always stalked, and the upper ones sessile. The texture is coriaceous; colour varying from dull olive to bright green in full grown pinnæ, though young ones are often yellow or reddish brown. The edges are sometimes entire and flat, sometimes finely toothed, and sonnetimes very wavy. The fertile pinnæ are narrow, but vary in different plants from one sixteenth of an inch to more than a quarter of an inch broad. It often happens that the lower part of a frond is barren and the upper fertile, though generally the barren and fertile fronds are distinct. Occasionally one side of the frond is barren, and the other fertile. In the same way the fertile pinnæ sometimes have a leafy base, though generally they have not. Sir J. D. Hooker defines the following as varieties :- 
A. Base of sterile pinnæ cut sharply off or almost wedge-shaped.

B. Base of sterile pinnæ having heart-shaped lobes overlapping the rachis.

C. Sterile pinnæ narrowed at base.

D. minor. Sterile pinnæ very thick in texture, with saw-like edges, and scattered dark scales on the stipes, rachis, and costæ.

The first three are connected by innumerable intermediate forms, but the last, Plate XII, Nos. $4,4 \mathrm{a}$, and $4 \mathrm{~b}$, is so very distinct as, in my opinion, to warrant its being classed as a different fern, unless of course connecting links occur in other countries, though not in New Zealard. It is extremely dark olive-green, and often variegated or shaded, and the lower pinnæ are deflexed like those of L. vulcanica. Like those of that fern too, the fertile fronds are much longer than the barren ones. The fertile pinnæ are at first quite linear, but afterwards get much wider, and cellular in structure, like those of L. Patersoni, and they trend upwards almost like those of L. fluviatilis. The stipes is quite black, and has curious white patches on its sides, apparently where scales have fallen off. Altogether it seems to connect Lomaria Procera with the other three plants, while at the same time it has peculiarities of its own. I have seen it only in two places, viz.,-Murimotu, near the base of Ruapehu, and near Dunedin : but from Dr. Hooker's classing it as a variety, it probably occurs elsewhere. In fact, from a passage in a letter from Mr. Colenso, I infer that he first found it in some other locality, and sent it to Kew, though he does not seem to have noted its having characteristics connecting it with other Lomarias besides L. procera. It is very harshly coriaceous in texture.

In Volume IX of the Transactions of the New Zealand Institute, page 49I, the late Mr. T. H. Potts mentions another form under the name of "Lomaria duplicata." In it the stipes forks and produces two distinct fronds, one of which is fertile, while the other is barren. I have occasionally seen forked fronds elsewhere, but in the Canterbury plant the type seems to have become constant, so as to constitute a good variety.

Lomaria procera is easily cultivated, and will bear more exposure than most New Zealand ferns, though it does not like wind, particularly draughts. Of course only the smaller forms are suited to pot-culture, but "variety minor" is well worth growing, though it requires more shade, and a far moister atmosphere than the others. In one form or other, Lomaria procera is found apparently throughout the Southern Hemisphere, from the Equator to as far south as the Campbell and Auckland Islands, and has variously been called "L. capensis," "L. Gilliesii," "Stegania procera," "Blechnum procerum," "Parablechnum procerum," "Osmunda procera," and "Osmunda capensis." It ranges, in New Zealand, from sea-level up to 4000 feet elevation, and occurs on all sorts of soils, and in all sorts of situations, even in crevices of rock, and on stumps and rotten logs. 


\section{LOMARIA FILIFORMIS. (Lo-ma-re-a fi-lif-or-mis.)}

\section{PLATE X., Nos. $3,3 \mathrm{a}$ and $3 \mathrm{~b}$.}

This fern is also one of the most common in the North Island, and extends into the Middle one, but apparently only for a short distance, being absent from the southern portion of the Colony. It is a very curious plant in its habits. It grows first on the ground, but soon sends out rhizomes in every direction. These are darkcoloured, slender, and scaly, and produce an abundance of fronds, varying from two to four inches long, by from half to three-quarters of an inch wide. These are pinnate, the pinnæ being stalked, rough and oval, with serrated edges, and all barren. These rhizomes creep on the surface of the ground, which they soon cover with a carpet of their fronds. When one of them reaches a tree, it begins to ascend, holding on firmly by aerial roots. It increases greatly in thickness, becoming often as thick as a man's little finger, but still retaining its scaly character. It is also very woody or fibrous in its texture. In this way it often climbs to a height of twenty feet or more up the trunk of the tree, and, soon after it begins to ascend, the character of its fronds entirely changes. They become enlarged sometimes to $3 \mathrm{ft}$. in length, and their pinnæ become long lanceolate, or oblong with rounded ends, and often four or five inches long, being, however, still stalked and having toothed edges. The colour, too, still remains of a dark rather shining green, and the texture harshly coriaceous. When the rhizome has climbed six or eight feet, the fertile fronds begin to appear among the barren ones. These are usually oval or oblong in shape, with very long linear pinnæ (whence the name filiformis, thread-shaped), so that they look very like bright green ostrich feathers, sticking out from the tree trunk, and drooping downwards. No one who has once seen this fern can ever mistake it, owing to its being so different from any other. It is said to occur in Fiji, but nowhere else except from there to New Zealand, and it does not seem certain even that it grows in all the intermediate islands. It is very easily cultivated. Any bit of the terrestrial rhizomes will grow readily; but to see the full character of the fern, it inust be planted at the foot of a tree, in a shady sheltered place, and allowed to climb. It is also called "L. pimpinellæfolia," "Osmunda reptans," and "Stenochlæna heteromorpha," by different writers. The last specific term is most descriptive of the character of the plant.

\section{LOMARIA FLUVIATILIS. (Lo-ma-re-a flu-vi-at-il-is.) \\ PLATE XXVII., Nos. 2 and $2 a$.}

This fern, which is also called "Lomaria rotundifolia," and "Stegania fluviatilis," is found in Australia and Tasmania, as well as in New Zealand. It is common all through the Colony, and may be looked for wherever there is a rather damp shady spot, though alluvial soils suit it best. It has a stout, erect, scaly rhizome, with a crown of many long, narrow, simply-pinnate fronds, spreading out horizontally, and a 
ring of tall erect ones within them. The stipes of the barren frond is short and scaly, and the rachis is also scaly, and of a brownish green colour. The frond itself is often eighteen inches long, by not more than two inches broad, being of the same width nearly from end to end. The pinnæ are round or oval, with indented edges, and very numerous. The lower ones are stalked, or very narrowly sessile; the upper ones more broadly so, and the terminal one rhomboidal or triangular. Sometimes the upper pinnæ are connected, that part of the frond being merely pinnatifid. Colour dark olive-green; texture sub-coriaceous, and rather rough. The fertile pinnæ have longer stipites, and the pinnæ are short, narrow and turned upwards, so as to lie close to the rachis. It occurs, certainly, up to 2000 feet elevation, and I think I have seen it even higher, round the base of Ruapehu. It is very easily cultivated, provided it has shade and moisture, and, from the manner in which its barren fronds droop over the edge of the pot, is very effective. It would be a good fern for basket culture, but for its requiring a good deal of water. I have seen very beautiful groups formed of its bleached fronds, stuck in vases under glass shades, as ornaments, its drooping character coming in very effectively in such work. It is also a very good fern for use in what is called splash-work, or for skeleton-leaves.

\section{LOMARIA NIGRA. (Lo-ma-re-a ni-gra). \\ PLATE XXV., Nos., 4 and $4 a$.}

This fern is also peculiar to New Zealand, where it is only found in dark damp woods at high levels. It is not plentiful anywhere, but seems more common on the moist West Coast of the Middle Island than elsewhere, and also to descend to a lower level. Its rhizome is short, thick, erect, and scaly, with a crown of fronds on its top. The stipes is short, erect, and scaly. Rachis also more or less scaly. The barren fronds are oblong, but usually wider towards the apex than below. They are cut, right down to the rachis, into oblong or rounded pinnæ with indented edges and broad bases. The terminal pinna is always very much larger than the others, and often lobed. The lowest pair of pinnæ are also larger than those just above them and often lobed. The texture is coriaceous; colour very dark blackish green (whence the name) and veins indistinct. The pinnæ of the fertile fronds are far apart, and very narrow indeed, in fact, linear; the terminal one being usually longer than the rest. The very dark colour of this fern renders it quite unmistakeable, but it has no beauty, and is only grown for curiosity's sake. It requires to be kept in a very moist case, and is so liable to have its fronds overgrown by moss, as only to be kept sightly by constant attention, for the moss seems to make the fronds rot. Still, with care, it can be kept alive for many years. I suspect that it is this liability to be destroyed by moss that makes it so rare, as otherwise there seem to be hosts of dark moist spots every way suited to it, but in which it does not occur. 


\section{LOMARIA MEMBRANACEA. (Lo-ma-re-a mem-bra-na-se-a.)}

PLATE V., Nos. 6 and 6 .

This pretty fern is peculiar to New Zealand, and is not by any means rare in the North Island, at low levels, though it seems to be scarcer in the Middle Island, and is said to be almost unknown on the West Coast. It generally occurs in damp situations, such as the banks of streams, and the bottoms of gullies, but attracts notice at once. The rhizome is about as thick as a man's little finger, erect, scaly, and occasionally rises an inch or two above ground, with a crown of sub-erect barren fronds, encircling an inner ring of erect fertile ones. The stipes of the barren frond is short and scaleless, and the rachis is also devoid of scales or hairs. The frond is ovatelanceolate, the lower pinnæ diminishing to mere auricles. The pinnæ are alternate, and oblong, with rounded ends, and serrated edges. They are generally widest near the ends, and then narrowed farther down, but widen out again to broad bases, sessile on the rachis. The terminal one is lobed and rather longer than the rest. Their colour is shining rather dark green, but appears lighter than it really is, in consequence of the membranous texture and distinct venation. The stipes of the fertile frond is much longer and the pinnæ are far apart, and quite linear, with decurrent bases extending down the rachis on their lower sides. The plant is very easy to cultivate, in sandy soil and leaf-mould, provided that the atmosphere around it is fairly moist. It is the L. pumila of Mrs. Jones' hand-book.

The last of our Lomarias belongs to quite a different group, which is distinguished by its sterile fronds being bi-pinnate or bi-pinnatifid. It is called

\section{LOMARIA FRASERI. (Lo-ma-re-a Fra-zer-i.) \\ PLATE XXIV., Nos. 4 and $4 a$.}

Has slender creeping rhizomes, from which slender caudices arise at intervals. These sometimes only just rise above the surface of the ground, but under more favourable conditions they assume a quasi-arborescent form often from two to three feet high. They are always fibrous and scaly, and bear crowns of barren and fertile fronds intermixed. Stipes moderately long, stout, erect, scaly at bottom, but smooth above, varying from yellowish to dark brown. Rachis smooth and winged throughout, the web widening out into pointed lobes between the pinnæ. Fronds ovate-lanceolate, and bi-pinnatifid, barren and fertile ones being alike, though the latter are generally rather the smaller. The pinnæ are tapering, and divided into deep pointed lobes, with slightly serrated edges, and decurrent bases. Texture varying from almost membranous to sub-coriaceous, according to situation, the harshest fronds occuring in the most exposed places. The lobes of the fertile fronds are slightly narrower than those of the barren ones, and are covered beneath with a golden yellow, or light brown mass of fructification, which gives the plant a very handsome appearance. 
This fern is common from a little south of Auckland to the Northern extremity of the North Island, but seems to disappear farther south, though it is said to have been gathered, by Mr. Lyall, of the Acheron surveying vessel, at Massacre Bay, in the Nelson Provincial District, as well as to have been found by other collectors near Collingwood. It is easily cultivated, in a warm moist atmosphere, when it will send out its creeping rhizomes and produce fresh caudices in a short time.

\section{GENUS DOODIA. (Doo-de-a.)}

So called in compliment to Mr. Samuel Doody, a London bookseller, who was Curator of the Chelsea Botanic Gardens, about 200 years ago, and was one of the first persons who took to the study of ferns as a special branch of botany. It is characterised by having sori oblong or slightly curved, superficial, placed in one or more rows, parallel with, and between, the mid-ribs and margins of the pinnæ. Involucres of same shape as the sori, and membranous. Veins forming one or two series of arches between the midrib and edge, with the sori placed upon them.

There is some difference of opinion among botanists as to the classification of the New Zealand ferns of this genus, some reckoning three or four distinct plants, while others regard them as merely forms of one and the same. I feel no hesitation, however, in adhering to the classification in the Synopsis, as it agrees with my own observations, after having actually cultivated the plants for many years, and with those of others who have done the same. It is, in fact, only by cultivating ferns that one can get a thorough knowledge of them. Merely judging of them by dried specimens, gathered in different localities, is sure to lead to mistakes. The distinction in the Doodias is so great that I can hardly understand its having escaped notice.

\section{DOODEA MEDIA. (Doo-de-a me-de-a.)}

This fern occurs in Australia, Tasmania, and the South Pacific Islands, as well as in New Zealand. It is common in the Northern portion of the North Island, but becomes rare and local farther south, and so far as I can learn has never been met with south of Cook's straits. It grows in very slightly shady places, and at Auckland I have seen it on the bases of cliffs, only just above sea-level. It used to grow on the hill-faces on the south side of Wellington Harbour, which is the farthest south of any locality in which I ever knew it to occur, but I fear it has disappeared, by reason of the extension of building and clearing of the ground, as it occured among low manuka scrub. It will grow on any poor ground, but will pay for better soil and shelter by increased luxuriance. I greatly doubt its being really distinct from the Australian "Doodia aspera," as my plants of the latter have, under cultivation, so completely assumed its character that, except by the brighter rose-colour of the young fronds, and a greater tendency to divide into separate crowns, I can see no difference between them. The 
merely pinnatifid character of $\mathrm{D}$. Aspera has entirely disappeared, and the fronds are now quite pinnate. I mention this because the same may be the experience of others, or they may find plants which they may think to be new, because they differ somewhat from the normal type.

Doodia media has a short, stout, scaly, erect rhizome, sometimes rising several inches above the surface of the ground, and after a time parting into separate branches, each of which produces a crown, and will, if cut off from the parent stock, make a fresh plant. Stipes short, stout, scaly at the bottom and sometimes throughout. Rachis generally smooth, but sometimes scaly towards its lower end. Frond long, narrow, and lanceolate, often widest in the middle, tapering very gradually below, and acuminate towards the apex; pinnate. Pinnæ very numerous. The middle ones are oblong, with rounded or obtusely-pointed ends, broad sessile bases, and serrated edges. The lower ones are more and more shortened and more narrowly sessile, till the lowest are round, and distinctly stalked. Occasionally the stalked pinnæextend above the middle of the frond. The upper ones become more and more widely sessile on the rachis, and it is only at the very top of the frond that they become pinnatifid. The terminal one is of the same shape as the rest but somewhat narrower. The colour is dark brownish-green (brown or rose in the young fronds); texture harshly coriaceous, and main veins very distinctly marked. The sori are short, and form two lines on each side of the costæ of the pinnæ, and parallel to them, being situated on cross veins connecting the main veins. Involucres membranous, and opening inwards but soon hidden by the sori.

There is a second form, distinguished as "D. connexa," which has longer, more membranous, and sub-lanceolate pinnæ, but as I and others have found the normal form change into it, under cultivation, it is evidently not entitled to specific distinction. A third form, called by Mr. Colenso "D. squarrosa," has the pinnæ so much narrowed as to appear distinct and almost linear, with decurrent bases This narrowed appearance however, arises, in a great measure, from the edges bending over, so as partially to corer the sori. The terminal pinna is also very much prolonged, and the texture unusually harsh. I have received specimens of it from Napier, from the Reverend gentleman himself, and from Wellington from Professor Kirk. It is certainly a very distinct variety, but I do not think it entitled to be regarded as a separate plant, as the difference is no greater than occurs in what are always classed as mere varieties of other ferns. All forms are easily cultivated, and do best in rather stiff soil with leaf-mould. They do not require much shade. I have lately received a plant from the hill-country between the Waitotara and Patea rivers. It was found farther inland than I ever knew D. media to occur before, and is of the "Connexa" type, having. grown in bush. 


\section{DOODIA CAUDATA. (Doo-de-a cau-da-ter.) \\ THE "MOKE-MOKE," OR SACRED-FERN OF THE MAORIS. \\ PLATE XX., Nos. 4 and 4a.}

This fern is supposed by the Maoris to grow naturally only at one spot on a spur of the Rimutaka range, whence its name, which means "solitary." It has, however, been found at other places, but when the natives are told so, they reply that "it must have been carried there." There is no question that they prized the fern sufficiently to carry it to distant localities, as I have seen plants that they had fetched from the Rimutaka, and thus it may have been spread to places far removed from its original habitat. Still, as it occurs in Australia, I believe it was more widely distributed in the North Island and its dependencies than the Maoris knew, though it is only met with locally. The Maoris profess to detect a very delicious fragrance in it, and say that they used it for scenting oil for the anointing of their bodies. I never could detect any scent in it, myself, though I have grown it for many years, and have only met with two Europeans who said they could do so. The one described it as like tobacco, but fainter, so that I fancy the smell arose from his own pipe or clothes. The other is a florist, who said he could perceive a peculiar smell in both it and Doodia media, when their fronds were ripe. As his ferns, however, grow in a greenhouse, containing many flowering plants, I think a mixed scent from things in bloom at that time may have been supposed to proceed from the Doodias. At all events if the fern really emits a scent, it requires unusually keen olfactory organs to perceive it.

Doodia caudata has a short, stout, erect caudex which seems to flatten out rather than divide, and thus soon produces a dense mass of fronds. My original plant which came from the Rimutaka, and must be more than twenty years old, is nearly a foot in diameter by nine or ten inches high, and has several hundred fronds, about half of which are fertile, and the others barren, for D. Caudata differs from D. media, in producing distinct barren and fertile fronds. The stipes of the barren frond is short, stiff, dark-coloured and hairy. The rachis woolly and dark-coloured below, but smooth and green above. The frond is oblong, pinnate, and rarely, if ever, more than four or four and a half inches long, inclusive of the stipes. The pinnæ are sub-opposite, the lower ones being rounded at the ends, and furnished with large rounded auricles or lobes which give them somewhat the trifoliated shape of a clover leaf. They are shortly stalked. Higher up these lobes are shortened, and the pinnæ become oval, or oblong with rounded ends. Towards the top they become sessile on the rachis, and the terminal one is lengthened, lobed, and obtusely pointed. The colour is bright green ; texture almost membranous; edges serrated and wavy, and venation indistinct. The barren fronds grow more or less horizontally, unless forced upwards by the fertile ones. The fertile fronds grow erect, or nearly so, and are often eight to nine inches long, including the stipes. The stipes is fully three times as long as that of the barren 
frond, and the pinnæ are far wider apart and usually alternate in the upper half. They are lengthened and narrow (whence the name "caudata," tailed), and have auricled bases. The lower ones are stalked, but the upper ones are sessile, and decurrent on the lower side and the terminal one is lobed and elongated. The cross veins, carrying the sori, are so close to the costæ that the sori form merely a broad dark-brown line along the centre of each pinna, with branches into the auricles. Involucres membranous, and opening inwards, but scarcely visible even when the frond is quite young.

This fern is very easy to cultivate, requiring little shade or moisture, and produces spores so abundantly that seedlings come up in large numbers in its vicinity; so that the wonder is that it is not more widely distributed. It likes light soil and leaf-mould.

\section{GENLS ASPLENILM. (As-ple-ne-um.)}

Has sori dorsal or sub-marginal, linear or oblong. Involucres similar in shape, straight or occasionally curved, single or double, flat or swelling, bursting along outer edge.

Sub-genus Euasplenium has veins free, simple or branched, sori linear, or linearoblong, straight or discoidal. It is divided into several groups, of which the following are represented in New Zealand, viz., The Trichomanes group, which has pinnate fronds with a wiry chestnut-brown or black rachis. The only fern in the Colony belonging to this group is

\section{ASPLENIUM TRICHOMANES. (As-ple-ne-um tri-kom-an-ees.)}

PLATE XXVIII., No. 8.

This has a short, stout, erect rhizome, sometimes rising an inch or two above the ground, and carrying a crown of numerous fronds. The stipes is rather short, smooth, and dark-brown. Rachis also dark-brown and shining. Fronds long, narrow, oblong * or lanceolate, sub-erect and divided into numerous oblong or oval pinnæ, which are arranged in pairs, stalked, and slightly indented at the edges. The sori are arranged in several lines, set obliquely to the costa, and on both sides of it. Involucres membranous. Colour bright green; texture sub-coriaceous.

This little fern, whose fronds seldom exceed six or eight inches long, is found in the Northern Hemisphere from the Azores and Great Britain, to Japan and North America, and up to a height of from 6000 to 8000 feet, on the Himalaya Mountains. Thence its range extends southwards to South Africa, Australia, Tasmania, New Zealand, and the South American Andes to Peru. Large forms, sometimes eighteen inches long, occur in Madeira and South America, and dwarf ones on the Andes. In New Zealand, it was first found on the Nelson Mountains, and has since been met with all along the Southern Alps, as well as on the Kaikouras and Banks' Peninsula, always 
at elevations of from 500 to 3000 feet. Mr. Thompson says it is found in the ranges of the North Island, from Wellington to the East Cape and Taranaki, and as far north as Tauranga, but I do not know on what authority, as I have never heard of its occurring north of Cook's Straits. If it does so occur, it must be very locally, and at very high levels. He also says it is an extremely hardy species, and grows readily under cultivation, but this does not agree with my own experience, as all the plants which I have had have soon died, apparently for want of mountain air, or because our Wanganui climate is too warm, or possibly because it likes to squeeze its roots into crevices of rocks, or chinks in old walls, a situation in which it often occurs in England.

The next group is known as the Asplenium marinum group, after an English fern so called from its growing on rocks, and in caves by the sea-side. These ferns have usually a coriaceous texture, bright green colour, and comparatively obscure veins. Sori nearly equal, in two rows, on either side of a distinct mid-rib. This group includes the following:

\section{ASPLENIUM FLABELLIFOLIUM. (As-ple-ne-um fla-bel-lif-o-le-um.)} PLATE VI., No. 6.

This curious fern is found in Australia and Tasmania as well as in New Zealand. It seems to occur from end to end of both Islands, but usually at some height above the sea, and in crevices of rocks, though I know of one instance in which it grows in rather sandy soil under a hedge. It is very easy to cultivate, and is one of the best of New Zealand ferns to plant in a hanging basket.

Its rhizome is small and erect, bearing only a few fronds. The stipes is long, thin, smooth, and generally brown below and green above. Rachis green. The frond is very long, and usually oblong or narrowly lanceolate. It has numerous stalked, or - narrowly-sessile, fan-shaped pinnæ, placed alternately on opposite sides of the rachis at considerable distances asunder and with lobed and toothed edges. The sori are few in number and radiate fan-fashion from the bases of the pinnæ. The involucres are membranous. The fronds usually terminate in a long thread-like continuation of the rachis, at the end of which there is a bud which takes root, and produces a fresh plant. These fresh plants will, however, form on the end of the thread, when the frond is hanging down over the side of a pot or basket, without the bud being in contact with the ground. Occasionally, however, a plant is met with which does not produce the thread, but has its fronds terminating in very large pinnæ of the same shape as the rest. At page 228, Vol. XX of the Philosophical Transactions, Mr. Colenso describes, under the name "var. ramosum," a forked or branching form found by a Mr. Hamilton in 1882 in woods near the town of Waipawa, Hawke's Bay. The fern is also called "Asplenium flabelliforme." 
ASPLENIUM FALCATUM. (As-ple-ne-um fal-ca-tum.)

PLATE XXI., No. 5.

This fern, which is also called "Asplenium polyodon," is found from end to end of New Zealand, but not far inland or at any great elevation, though it is said to have been met with up to 2000 feet in the north of the Colony. It also grows in South Africa, India, Ceylon, Malacca, and thence southward through Polynesia and Australia. It varies in form in different localities; that found in New Zealand being what is known as variety "Forsteri," with the pinnæ broad at the bottom and rather deeply lobed and toothed. It, however, differs very considerably in different places, so much so, as to make it doubtful, in some cases, whether it should not bear another name. It is usually found growing among moss and other vegetation, in the forks of trees, on rotten logs, or on roots, seldom if ever on the ground itself, unless among moss in crevices of rocks. It is pretty abundant in bushes near the coast, and easily grown in leaf-mould or rotten wood. When young, it bears a very strong resemblance to Asplenium flabellifolium, but the fronds are shorter, the texture far thinner, and the colour a lighter green.

It has a short, stout, slowly-creeping, scaly rhizome, producing numerous fronds. The stipes is long, stout, erect, dark-coloured, sometimes smooth and sometimes slightly velvety or hairy. Rachis the same. Frond long-oblong, or lanceolate, pinnate. The pinnæ are numerous, stalked, dark-green, coriaceous, and very peculiar in form, owing to their being unequally divided. The lower side slopes very gradually away from the stalk, and then tapers, being comparatively narrow throughout, while that above the costa widens out at once into a more or less rounded auricle or lobe, and then contracts ard becomes tapering like the other. Both sides are lobed and toothed. The upper surface is usually rather glossy, and the under one lighter-coloured and sub-tomentose. The sori are arranged in lines, radiating more or less from the stalk. Involucres membranous.

The above is the usual form of the fern, but sometimes the large lobe on the upper side of the pinna is almost wanting; that side being merely a little wider and more suddenly widened at its base than the other. Sometimes, again, the point of the pinna is much prolonged, so as to form a sort of tail, and approximate very closely to the next species. At Christchurch, again, I lately saw at a Horticultural show, a plant marked "Asplenium falcatum," which had not only no large lobes on the upper side of its pinnæ, but was of a bright shining green colour and thick texture. so like "Asplenium obtusatum, variety obliquum," that I thought it was wrongly named, till I examined the sori, and found that they radiated from the stalk. As I had to leave by steamer the same evening, I was unable toascertain to whom it belonged, or from whence it came. It may, of course, have been an imported plant, but it was at any rate distinct in appearance from any form of Asplenium falcatum that I had previously seen. 
ASPLENIUM CAUDATUM. (As-ple-ne-um cau-da-tum.)

This fern in its typical form occurs in the Kermadec Islands, and is, therefore, usually included in the lists of New Zealand ferns. I should not, however, have mentioned it, but for a doubt whether some of our forms of what is called Asplenium falcatum do not properly belong to it. It is mentioned in the Synopsis as very doubtfully distinct from A. falcatum, and Mr. Cheeseman, who gathered it at the Kermadecs says, at page 177 , Volume XX, of the Philosophical Transactions, that it is " hardly separable from A. falcatum as a species." Bath apparently grow together everywhere but in New Zealand, and it is said in the Synopsis that "the best characteristic of $\mathrm{A}$. caudatum is that the sori are much confined to the centre of the pinnæ, being often restricted to two parallel rows close to the midrib," a distinction of so trifling a character as hardly to attract notice. I think it quite likely that the same peculiarity may be found in our tailed forms of A. falcatum, and, therefore, note it in order that collectors may look out for it, as otherwise they would probably hardly notice it.

\section{ASPLENIUM OBTUSATUM. (As-ple-ne-um ob-tu-sa-tum.)}

\section{MAORI NAME "PARETAO."}

PLATE XXIII., No. 3.

This fern, in one form or another, is found in South America, the Southern Polynesian Islands, and Australia, as well as in New Zealand and the Chatham and Auckland Islands, but I have no means of knowing which of its many varieties occurs in each place. It is very common in New Zealand, but does not extend far inland, or to any high level. The following, which is its typical form, only occurs on rocky soils close to the sea, and rarely, if ever, exceeds two feet high. Rhizome stout, scaly, branching, and slowly creeping, and thus producing separate crowns, or rather tufts, of only a few fronds each. Stipes long, stout, erect, dark brown or gray on under side, and scaly at base, but bright green and smooth above. Rachis also brown or gray below, bright green above, smooth and winged. Frond pinnate, oblong, or sometimes slightly narrowed below. Pinnæ shortly stalked, but with narrow wings extending down the stalks, set nearly at right angles to rachis, and lower ones often deflexed, broadly oblong, rounded or obtusely-pointed at the tips; bright glossy green, and very thick in texture. Edges toothed; veins prominent on upper surface. Sori arranged in many parallel lines, set obliquely to the costa, and extending nearly to the edges. Involucres membranous, white, and very prominent.

\section{VAR. OBLIQUUM. (ob-li-quum.)}

Like the last in every respect except that the pinnæ are much narrower, taper throughout to sharp points, and are set so as to point very obliquely upwards. Grows in similar situations, but usually in more sheltered ones. 


\section{VAR. SCLEROPIUM. (scle-ro-pe-um.)}

Sometimes like one and sometimes like the other of the above, but has the teeth much deepened (sometimes half-way to the costa) so as to form a fringe rather than a serrated edge. It occurs only in the south of New Zealand, and in its most perfect form in the Auckland Islands.

\section{VAR. LUCIDUM. (lu-sid-um.) \\ PLATE XIII., No. 6.}

A very much larger plant than either of the above, being often four feet high, and growing in the bush farther from the sea. It has broad, tapering, pointed pinnæ with generally rather deeply toothed edges. It is of a very bright glossy green (whence the name) and very much thinner texture. The veins and sori, too, are more numerous and closer together. This, however, and Var. obliquum, merge very gradually into each other, the pinnæ of both being obliquely set. In both, too, it is not unusual to find a pinna or two with narrowly-sessile lobes at the base.

\section{VAR. PAUCIFOLIUM. (pau-sif-o-le-um.)}

This is only a stunted form of Var. lucidum, with very few pinnæ. It generally occurs in tolerably open ground, among fern and manuka scrub or scrubby bush, rather than in heavy bush. The young shoots of all the above are eaten by the Maoris.

\section{VAR. LYALLII. (Ly-al-le-i.) \\ PLATES XXIII., No. 4, and XXV., No. 2.}

This variety was formerly supposed to be confined to Nelson and Otago, but occurs also in the Canterbury Province and Chatham Islands, and I found it some years ago, growing in a hollow at Evans' Bay, Wellington, where several other plants of it were procured afterwards, though it is probably extinct there now. It is a small plant not more than fifteen to eighteen inches high, and only found close to the sea. It creeps less than either of the other varieties; in fact, does little more than produce fresh crowns around the original one, and thus, after a few years, forms a very handsome compact plant, with a great many fronds. It is of a duller green than either of the other varieties, and less glossy. The texture varies considerably, some plants being nearly as thick as the typical A. obtusatum, and carrying their fronds erect, while others are as thin as Var. lucidum, and have drooping fronds. It has the lower portion of its lower pinnæ, and sometimes nearly the whole length of all of them, cut into deep rounded, inore or less narrowly sessile lobes, extending nearly to the rachis, and in its extreme form is only distinguishable from Asplenium bulbiferum by its darker green and straighter sori; in fact, it forms a connecting link between A. obtusatum and that fern, and in the Synopsis is included in the same group as the latter, though it is unquestionably only a form of A. obtusatum, the whole series of links being complete. 
I lately found in the space of a few square yards, at St. Clair, near Dunedin, a complete sequence, from an apparently small A. lucidum, with one or two slight indentations at the bases of the pinnæ, up to the extreme form shown at Plate XXIX, No. 2.

The next group is called the "Asplenium cuneatum group." It has fronds bi to quadri-pinnate, with coriaceous texture, and ultimate divisions linear or ovate-cuneate, often glossy on upper surface; venation sub-flabellate. It includes

\section{ASPLENIUM HOOKERIANUM. (As-ple-ne-um Hook-er-e-a-num.)}

PLATE XVI., No. 4.

This is tound in S.E. Australia as well as in New Zealand, and is by no means uncommon, from just above sea-level up to certainly 2000 feet elevation, in the North Island, and is said to be even commoner in the Middle one. It seems only to grow on dry hill-sides or steep faces, and not in heavy bush. In the southern parts of the Colony it is said to grow on rocky ground, but in the North island I have only found it on sandy or gravelly soils. It is also called "A. adiantoides."

This pretty little fern has a rather stout, erect rhizome, bearing a crown of a few fronds only. The stipes is usually rather short, thin, erect, green or yellowish-brown, with a few scales, particularly when young. Rachis the same. Frond oval or oblong bi or tri-pinnate, the costæ being long and bare. The pinnules are very few in number, stalked, and vary somewhat in form. Some are simply rounded at the ends, and wedge-shaped towards the stalk, while others have the centre somewhat eiongated with rounded lobes on both sides. Edge sometimes entire, sometimes toothed or slightly lobed. Sori few in number, rather radiating from the stalk. Involucres white and membranous. It seldom, if ever, exceeds fifteen inches high.

\section{VAR. COLENSOI. (Co-len-so-i.) \\ PLATE XXVII., No. 1.}

This is precisely similar to the other in growth, and occurs in the same situations, though it is less common. In the Synopsis it is included in a different group (called the "Asplenium cicutarium group"), but unquestionably wrongly so, for not only do the two plants grow together, but sometimes fronds of both forms are found on the same plant. Of course in such cases neither frond is quite up to the typical form, but more or less intermediate, but their occurrence on the one plant proves the identity of the typical ones. Var. Colensoi has its pinnules divided into deep narrow lobes, with the result that the sori become submarginal, and hence Sir W. J. Hooker classed it as a variety of A. Richardi. Both varieties are very easily cultivated in sandy soil and leaf-mould (though I have found that plants raised from spores thrive the best); but they are terribly liable to be attacked by slugs and woodlice. In fact, the tender 
herbaceous character of these ferns seems to make them so attractive to these insects that it is very difficult to protect them from the attacks of the little vermin, who eat the young buds before they have time to unroll. Standing the pot in a saucer of water, or else putting a bell-glass over it, with its bottom edge resting in water, to prevent the insects from creeping under it, are good protections.

The next group is called the "Asplenium bulbiferum" one, but as the only New Zealand fern belonging to it is

\section{ASPLENIUM BULBIFERUM (As-ple-ne-um bul-bif-e-rum), MAORI NAME "MOKU," \\ PLATE VI., No. 5,}

The description of the plant will serve for that of the group too. This is the commonest of all New Zealand Asplenia, being found in the bush throughout the colony from a little above sea-level to $4000 \mathrm{ft}$. elevation or upwards. It is, however, absent occasionally from considerable tracts of country. It is often $3 \mathrm{ft}$. or more in height. Its young shoots are cooked and eaten by the Maoris, and are very like asparagus in flavour and tenderness; so that surveyors and others working in the bush find them a very pleasant addition to their bill of fare in the spring of the year. The plant is found in North India, Penang, Samoa, New Caledonia, S.E. Africa, and adjacent islands, Central America, Australia, Tasmania, and the Chatham Islands; and is also called by the synonyms of A. tremulum, A. Fabianum, and Cœnopteris appendiculata. It has a stout, erect, slightly scaly rhizome, sometimes rising several inches above ground, and bearing a crown of numerous fronds. The stipes is short, stout, erect, scaly and often dark-coloured at base, but smooth and green above, or only slightly scaly when young. Rachis smooth, green, winged, slightly scaly when young, but smooth afterwards. Fronds usually oval in form, tenderly herbaceous in texture, bright green in colour, and varying from pinnate to tripinnate, according to size, age, and situation. Pinnæ numerous (often overlapping) stalked, and divided into oval or lanceolate pinnules, which again are more or less cut or indented at the edges. In the typical plant, the pinnules are cut into rather broad oblong lobes, on the underside of which the sori are placed The sori are short and broad, and when ripe almost cover the under surface of the whole frond. Involucres broad, membranous, white or very pale green, and conspicuous; opening inwards towards the costæ. In the North Island this fern may be identified, in all its forms, by the growth of young plants on the upper surface of its fronds. Sometimes twenty or more of such young plants are seen to be growing on one frond; and the manner of their production is doubtful, as they seem to occur on all parts of the upper surface indiscriminately, and are often found on fronds of plants, which are too young to produce sori. If the 
piece of frond on which they grow is laid on the ground, and its edges covered with earth, the young plants will send down roots and grow independently. They always have a small scale, like a prothallus, at their base, and yet it is certain that they do not grow from spores that have fallen on the frond, but spring out of the substance of the frond itself. In the Southern portion of the Middle Island, however, these growths seem almost unknown.

\section{VAR. LAXUM (lax-um),}

Is usually a smaller plant, with narrower fronds (seldom exceeding two feet in height), and divided into longer, narrower lobes, so that the sori become sub-marginal. It is more drooping in its habit than the ordinary form and approximates to A. Hookerianum, var. Colensoi.

\section{VAR. TRIPINNATUM OR FABIANUM (tri-pin-na-tum), PLATE XXIII, No. B,}

Is, as its name implies, tripinnate, and has also long narrow lobes with sori so nearly marginal, that some persons regard it as rather a form of A. flaccidum. I have, however; always regarded it as unquestionably a form of $\mathrm{A}$. bulbiferum on account of its producing young plants on its upper surface, but as a similarly proliferous form of unquestionable A. flaccidum has lately been found at. Waitotara, I am now more disposed to regard it as a transitional type.

There is another tripinnate form that seems not to have been distinctly recognised and separately classed, though it occurs in both islands. It has numerous distinct small stalked pinnules, and bears a strong resemblance to coarse Asplenium Hookerianum. It seems, indeed, a transitional form.

\section{VAR. SHUTTLEWORTHIANUM (Shut-tle-worth-e-a-num),}

Is included by Mr. Thompson, but I think erroneously; for though it occurs at the Kermadec Islands, it has not, as far as I know, been found in New Zealand. It is a plant about eighteen inches long, which grows pendulous on tree trunks, and is a form of A. flaccidum rather than of A. Bulbiferum, and is doubtfully classed in the Synopsis. It is quadri-pinnatifid, and altogether very narrow in its foliage, the ultinate segments being very small and wedge-shaped, with marginal sori. It is such a lovely plant, that I should be only too glad to find that it occurred in New Zealand.

\section{SUB-GENUS DAREA (Da-re-a),}

Has the veins simple, the ultimate divisions narrow and linear; sori marginal or sub-marginal, linear or linear-oblong.

A group of this sub-genus is called the Cicutarium group, from the thick fleshy character of the foliage of the plants included in it. The New Zealand ones are 
ASPLENIUM FLACCIDUM. (As-ple-ne-um flax-id-um.)

PLATE XII., No. 2.

This fern in its various forms in found in South Africa, Australia, Tasmania, Polynesia, northward to the Sandwich Islands, and the Chatham and Auckland Islands, as well as throughout New Zealand. It grows in various places. Its largest forms occur among moss, on tree-trunks, roots, or forks of branches; but smaller ones, also among moss, in crevices of rocks. It varies wonderfully in form in different situations; in fact, a complete series would be curious and interesting. In its various forms it has been called "Asplenium heterophyllum," "A. odontitis," "Cœnopteris flaccida," "C. Novæ Zelandiæ," and "Darea flaccida."

The typical form is probably that most generally met with, pendulous on tree trunks, in the New Zealand forests. It has a short, stout, erect, scaly rhizome, bearing a good many fronds, and in large plants exhibiting a tendency to creep slightly, or divide into separate crowns. The stipes is stout, smooth, or slightly scaly at the very base, green, and very variable in length. Rachis also smooth and green. Frond oblong or lanceolate, pinnate, and sometimes $3 \mathrm{ft}$. long. Pinnæ more or less distant, opposite, sub-opposite, or alternate (sometimes all three on the same frond), long lanceolate, pointing much upwards towards the apex of the frond, and cut nearly to the costæ into narro:v tapering pointed lobes, which also point much upwards, and are decurrent on their lower side, so as to form a wing all along both sides of the costæ. Colour bright green; texture very thick; in fact, fleshily-coriaceous. Sori sub-marginal on the upper edges of the lobes only. Involucres membranous, placed beneath the sori, green, and indistinct. Occasionally, but very rarely, a plant is found of which the fronds are tripinnate towards the base; and a variety producing young plants on its upper surface has lately been found at Waitotara by my son, Mr. F R. Field. It is a small form, about $2 \mathrm{ft}$. high only, and grows on the ground. The lower pinnæ have one or two narrow lobes at their bases, cut nearly to the costæ, and the upper lobes are quite short and rounded. It appears rarely to produce sori, but to be propagated by the little plants dropping off and taking root, as each large plant has a number of these young ones under and around it ; and when soriferous the sori are not marginal, but on the back of pinnules like those of $\mathrm{A}$. bulbiferum, showing it to be a connecting link with that fern Another form, also found in the forests of the North Island, particularly at high levels, has very few pinnæ, and those very long and quite linear, with very short, almost rudimentary lobes; in fact, it is very like a large, long form of the European Asplenium septentrionale. Another form has the pinnæ curved like a scythe blade. Another has shorter, more triangular fronds, with more numerous pinnæ, which are far slenderer, and have longer, narrower lobes, giving it altogether a more feathery appearance. It also usually occurs at high levels. Another form, which occurs on the rocks by the sea shore near Wellington, is very thick indeed, and 
stunted, not more than 6in. high. The frond grows erect, and is broadly triangular in shape, with short oval or triangular pinnæ, not very deeply lobed. It parts into separate crowns more than other forms. Other dwarfed forms, intermediate between the normal and the last described, grow in the crevices of rocks in open ground throughout the colony, particularly at high levels. I have already said that the quadripinnatifid plant known as "A. bulbiferum var. Shuttleworthianum" seems more properly to belong to this species. All the varieties are very easily cultivated, particularly in finely pulverised rotten wood or leaf-mould.

\section{ASPLENIUM RICHARDI. (As-ple-ne-um Rich-ard-i.) PLATE XXVIII., No. 5.}

This is a plant that only occurs in New Zealand, and is a sort of puzzle to collectors, because it is a question how far it ought to be classed as a distinct species. It seems to form a connecting link between several other ferns, and to pass, by insensible degrees, into them. In its large forms, sometimes $1 \mathrm{ft}$. high, it looks like Asplenium bulbiferum var. tripinnatum, with the thick texture of A. flaccidum. In other smaller ones it is only distinguishable by its thick texture from A. Hookerianum var. Colensoi; while in others, again, it seems to be merely a narrow triangular ovate or lanceolate A. flaccidum. The first of the above forms is the only one which I know to occur in the North Island; but I have seen fronds and plants of all the others in possession of collectors at Christchurch and Dunedin, and was surprised to find how they differed. The frond drawn in the plate was taken from the plant which was the most distinct from all other species of any which I saw, and it may therefore fairly be regarded as the typical form.

The rhizome is short, stout, erect and slightly scaly, with a crown of about eight fronds. Stipes of medium length, erect, stiff, green, and slightly scaly at very base only. Rachis smooth, green, and slightly flexuous. Frond long-triangular, tri-pinnate. Pinnæ and secondary pinnæ broad and stalked, the latter being flabbellately cut, nearly or quite down to the costæ, into long, narrow, oval or lanceolate pinnules or lobes, bearing sori on the lower portion of their upper edges only. Sori short, marginal and black. Involucres membranous, pale green, and not very distinct. The plant was growing well in a gentleman's fernery at Dunedin, and I think he said it came from near Queenstown, and I have since received a similar one from Mr. J. B. Armstrong, of Christchurch. As my readers will see, it bears a resemblance to A. bulbiferum var. A. tripinnatum, A. Hookerianum var. Colensoi, and also to A. flaccidum, and yet is distinct from either, partizularly in the fan-like arrangement of its ultimate divisions.

\section{SUB-GENUS ATHYRIUM. (A-thy-ti-um.)}

Distinguished by having the veins free and sori more or less curved, sometimes even horseshoe-shaped. It includes 
ASPLENIUM UMBROSUM. (As-ple-ne-um Um-bro-sum.)

PLATES V., No. 2, and XXIX., No. 4.

This very handsome fern is also called "Asplenium Australe," "Asplenium Brownii," Asplenium physosorus," "Allantodia Australis," and "Allantodia tenera," the latter name from the Greek word allantos, a sausage, referring to the curved form of the sori, and the manner in which they swell up as the capsules grow, until at length they burst open along the edge farthest from the vein. The fern is found in the Northern Hemisphere, from Madeira and the Azores and Canary Islands to Ceylon and Java, and on the Himalayas it ascends to 6000 or 8000 feet. In America it occurs in Ecuador and Peru, and in the southern part of the Eastern Hemisphere it extends to Australia, Tasmania, and New Zealand. It is tolerably abundant from Auckland northwards, occurs locally southward to Cook's Straits, and has been gathered at Nelson; but apparently nowhere farther south. It grows in rich deep alluvial soil, in warm damp places, but not in deep shade. Under favourable conditions it will grow five feet high, with fronds two feet or more in breadth; but varies so much in size and form that it is not easy to say what is its normal type. I will, therefore, take the largest that I know, which occurs at Waikato, Upper Wanganui, and Rangitikei, and probably elsewhere also. The rhizome is stout, and slightly creeping, and bears a crown of few fronds. Stipes long, stout, erect, scaly at base, smooth above, brown or brownish green. Rachis same colour, and smooth. Frond broadly deltoid, tripinnate below, bipinnate above. The pinnules are stalked below and sessile above, long-oval, with edges cut into rather deep rounded lobes. Sori numerous, and when fully developed almost covering the under surface of the pinnules. Involucres membranous, white, and much swollen, till they burst open; after which they are almost hidden by the capsules. Colour dark glossy green; texture usually almost membranous but sometimes harsh, and venation distinct.

Var. parvifolium occurs near Auckland and at Taranaki. It is similar to the above, but rarely exceeds three feet high, and its foliage is very much smaller. The sori too are far less numerous, and do not cover the pinnules in the same way. To my fancy it is the prettiest form of any; and I noticed that it was preferred to the other forms, as a pot-plant, by fern-cultivators at Auckland. In tact, I scarcely saw any plants of the larger kinds, except in regular ferneries.

Var. hians (Plate XXIX., No. 4), which occurs in Australia and South America, is, I believe, only found in New Zealand, at Wanganui. It is a coarse broad-foliaged form, three feet to five feet high, with its pinnules widened at the base, falcate in shape, and cut into deep rounded or pointed lobes. The sori are tolerably numerous, but never cover the under-surface of the pinnules, and towards the base of the frond they sometimes occur on both sides of a vein, which causes the plant to be classed in the sub-genus Diplazium in the Synopsis. From having grown it for many years, 
however, I am quite certain that it is only a form of A. umbrosum; as in their early stages it is quite impossible to distinguish between plants of it and of var. parvifolium. I have a slightly crested form of it. It is very easily cultivated in sandy soil, mixed with leaf-mould; as, indeed, are all the forms of A. umbrosum. They all die down in winter, and re-appear in spring; so that probably they would not survive the frosts of the Middle Island, unless under shelter.

Another Asplenium, of the sub-genus. Diplazium, was found by Mr. Cheeseman, at the Kermadecs, about two years ago, but is not known to occur in New Zealand.

\section{TRIBE ASPIDIÆ. (As-pid-e-æ.) \\ "SHIELD FERNS."}

So called from aspis, a shield, because the involucre is round and covers the sorus. The botanical definition includes the following characteristics. Sori dorsal, sub-globose, rarely elliptical. Involucres superior, similar in shape to sori, and fixed by the centre or by a sinus.

\section{GENUS ASPIDIUM. (As-pid-e-um.)}

Has the sori sub-globose, dorsal, terminal on veinlets. Involucres orbicular, fixed by the centre. All the N. Z. Aspidia belong to the

\section{SUB-GENUS POLYSTICHUM. (Poil-ist-ik-um.)}

Which has the veins all free; texture coriaceous; and teeth awned, that is having a sort of thorn or claw at the point.

\section{ASPIDIUM ACULEATUM. (As-pid-e-um a-cu-le-a-tum.) "PRICKLY SHIELD FERN." \\ PLATE VIII., No. 2.}

Rhizome stout, hard, erect, sometimes forming a caudex two feet to five feet high, and bearing a handsome crown of fronds. Stipes variable in length, stout, brown or grey, and more or less thickly covered with large dark scales. Rachis the same, and often clothed with hairs also. Fronds sometimes three feet long, oblong, long-oval, or lanceolate, bipinnate. Pinnæ and pinnules many and stalked: the latter very broadly lanceolate, almost rhomboidal, and rather deeply and sharply toothed. Texture coriaceous; colour usually dark olive-green. Sori numerous and near to costæ. Involucres round and flat. The above may be called a general description; but the fern varies so greatly in different localities, and even in the same neighbourhood, that it would be impossible to specify all the forms, from their passing into each other by imperceptible gradations. The New Zealand fern is what is generally classed as "Var. vestitum ;" but I lately saw in the "Waterfalls Gully," near Dunedin, plants 
which, if they had been growing in a fernery, I should have at once said were from England, as the fronds were short, almost deltoid, and had the lower pinnæ considerably deflexed. At Wanganui I have seen plants with short ovate fronds, and almost black in colour; while others from the West Coast of the Middle Island have been of a golder brown, rather than green hue. Some plants, too, are very much harsher in texture than others, and there is enormous variation in the hairiness or scaliness of different plants. In some plants, the lower part of the pinnules is auricled on the upper side, but in others not so. Still there is a general resemblance that makes the fern quite unmistakeable. Sometimes the caudex is branched, and has several crowns. There used to be a plant in the Makirikiri Valley, near Wanganui, with seven branches, the tallest of which was fully five feet high; but I believe it has been destroyed through the clearing of the bush.

This fern is found throughout New Zealand, and grows in both light and heavy bush, as well as among mere scrub. I have seen it at all levels from a few feet above the sea up to over 3000 feet elevation, and more abundant at the high levels than at low ones. It also seems far more abundant in the Middle Island than in the Northern one, particularly at low levels. It seems, in its various forms, to occur all over the world, though it is said to be rare in the extreme north of Europe, Asia, and America. The New Zealand plant has also been called "A. venustum," "A. pulcherrimum," "A. Waikarense," and "Polystichum vestitum." It is very hardy, and easy to cultivate, and is sometimes crested. I have also seen a plant with branching fronds. A form of it called Aspidium proliferum occurs in Tasmania, and has lately been found near Dunedin. It bears buds all along the upper side of the rachis, where the pinnæ are joined on to it, and every bud becomes a new plant. I also saw another very curious proliferous form in a friend's fernery at Dunedin. Each frond had a very large bud on the under side of the rachis, just where the pinnate lateral pinnæ ended, and the pinnatipartite portion of the frond began. When the frond begins to wither, the weight of the bud bears down the end, till the bud touches the ground, when the bud takes root and grows independently. Before this occurs, however, the bud will have produced a crown of several good sized fronds, which come up on both sides of the rachis; so that there is a handsome young plant on top of the parent frond. There is also a plant, which was called by Mr. Colenso, "Polypodium sylvaticum," but is classed in the Synopsis as merely a non-indusiate form of A. aculeatum. I do not know how it appears at other parts of the Colony, but the plants which I have seen near Wanganui have not only no involucres, but are so much broader in the fronds, longer in the stipes, looser in the general foliage, and narrower in the pinnules, that $\mathrm{I}$ think it may fairly be considered a distinct fern. It is possibly classed with Asp. aculeatum, because one English and some South American forms of that fern have also no involucres. 


\section{ASPIDIUM CYSTOSTEGIUM. (As-pid-e-um sis-tos-te-ge-um.) \\ "THE EGMONT FERN." \\ PLATE VIII., No. 3.}

This plant is confined to New Zealand. It has been found on Tongariro and Mount Egmont in the North Island, and at heights of from 3000 to 6000 feet, in a number of places, all along the Southern Alps in the Middle Island: so that it no doubt occurs near the snow line throughout the Colony. It only differs from A. aculeatum in being a far smaller plant, with much brighter softer foliage; in having its upper pinnæ more crowded, the lower ones often twice divided (so that the frond is tripinnate below), the sori more numerous, and usually confined to upper part of fronds, and both them and the involucres far larger. The caudex often branches and produces several crowns. Mr. Thomson says "it is extremely hardy, and can be cultivated with the greatest facility." Of its hardiness there can be no doubt, or it would not grow where it does; but the experience of fern-growers in the North Island differs from that of Mr. Thomson; and as I did not see a single plant of it in cultivation in a number of ferneries which I lately visited at Christchurch and Dunedin, and in some of which the Alpine varieties were a speciality, I fancy Mr. Thomson is wrong, and that the fern requires the mountain air to enable it to thrive.

\section{ASPIDIUM RICHARDI. (As-pid-e-um Rich-ard-i.)}

PLATE XIII., No. 4.

This fern is very common throughout the Colony, and is found in all sorts of situations, but not in very wet places. I have seen it in heavy bush, light bush, scrub, on faces of banks, under hedges, in crevices of rocks, and on grass tussocks in a swamp. It is also reported from Fiji, so that it probably occurs in other islands between there and New Zealand. It was called "Polystichum aristatum" by Sir W. Hooker, but this was apparently a mistake, as it and A. aristatum differ very widely.

A. Richardi has a short, thick, scaly rhizome, and a crown of few fronds only. The stipes is long, stout, erect, dark-coloured and scaly, particularly towards the base. Rachis also more or less scaly. Frond oblong or triangular, bi or tri-pinnate. Pinnæ divided into broader or narrower lanceolate pinnules, the lower of which are stalked and the upper sessile. These are also more or less deeply cut into sharp teeth. Texture harshly coriaceous; colour dark shining olive-green above, often woolly or scaly below. Sori varying much in size, generally in two rows, half-way between costa and edge. Involucre membranous, white, with small black dot in centre. It will grow most readily, and requires but little care, as almost any soil will suit it.

The principal differences of form are that, in the Northern plants, the pinnules are narrower, more tapering, and less deeply toothed than in the Southern ones. The forms of the latter; which have their lower pinnæ again pinnate, are also generally broader and more triangular in the frond. A very curious form was also found at Wellington 
by the Venerable Archdeacon Stock which has deeply crenate edges. I have also seen plants with crested fronds at Christchurch and Dunedin.

\section{ASPIDIUM OCULATUM. (As-pid-eum oc-u-la-tum.) PLATE XXIX., No. 2.}

This is one of the ferns which is a puzzle to collectors. It is supposed to occur at Nelson, Akaroa, Wairarapa, and Wanganui, as well as in the Chatham Islands; but authorities differ as to whether the New Zealand plants are it or not. I have tried to get at the truth, with the result that I am very doubtful whether it is a distinct fern, or only a form of Aspidium Richardi. Professor Kirk says that the typical plant only occurs in the Chatham Islands, where it grows sometimes four feet high, and has far softer foliage than A. Richardi, and Mr. Colenso seems to agree with him, as he told me he could see no real difference between the Wairarapa plant and A. Richardi, or words to that effect. Mr. T. W. Kirk, on the other hand, appears to regard the Wairarapa fern as real A. oculatum, and kindly directed me where to find it, but I could see nothing differing from the Wanganui plant, which Mr. J. Buchanan, formerly of the Wellington Museum, pronounced to be "oculatum," while Professor Kirk said it was only "Richardi."

Aspidium oculatum is, in fact, precisely like A. Richardi, except that it has longer narrower fronds, softer foliage, more downy under-surface, and very large sori, the involucres of which have a larger black spot in the centre (whence the name which means "eyed") and a reddish or blackish margin. The New Zealand plants seem the connecting links joining it to ordinary A. Richardi.

\section{ASPIDIUM CAPENSE. (As-pid-e-um Ca-pen-se.) PLATE VI., No. 2.}

This large handsome fern is so called because it was first discovered at the Cape of Good Hope; but it is found also all over South Africa, Australia, the Polynesian Islands, the West Indies, and all through South America, as well as in New Zealand and the Chatham Islands. It is found throughout New Zealand in bush, but not in wet bush, unless on logs. It grows indiscriminately on the ground and on logs, and often ascends tree-trunks to a considerable height. I have also seen it growing among the moss and rubbish in the forks of branches, and on stems of tree-ferns. It is also called "Aspidium coriaceum," "A. Cunninghamianum," "Polystichum coriaceum," and "Polypodium adiantiforme." It has moderately thick, creeping, scaly, rhizomes, often spreading over large areas and sending up rather distant fronds. Stipes stout, long, erect, brown or grey, scaly at base but smooth above. Fronds large (often two feet long by one toot broad), ovate-pointed or rhomboidal, bi or tripinnate. Pinnæ stalked, and pointing somewhat upwards. Lower pinnules also stalked, upper ones sessile, oval or lanceolate, cut nearly half way to the costa into 
bluntly-pointed lobes, which, as well as the pinnules themselves, point upwards. Sori numerous, usually in two rows, and very variable in size, being sometimes quite small and at others very large. Involucres membranous, round and white. Sometimes they are very distinct, and quite cover the young sori, even when these are large, but are afterwards completely hidden among the ripening capsules. 'Other plants seem to have no involucres at all, whence the fern has sometimes been classed as a Polypodium. Texture harshly coriaceous : colour dark brownish or golden green. It is almost hopeless to grow this fern from portions of the rhizomes, but if a very young plant is carefully taken up, and planted in good vegetable mould, it will thrive well. It will soon, however, outgrow even the largest-sized pot, and have to be transferred to the soil of the fernery, or better still a shady sheltered place in the garden.

\section{GENUS NEPHRODIUM. (Nef-ro-de-um.)}

Named from the Greek word "nephros" a kidney, on account of the shape of its involucres. It has sub-globose sori, terminal on veinlets. Involucres heart or kidney shaped, attached by the indented part, technically termed the sinus.

\section{SUB-GENUS LASTREA. (Las-tre-a.)}

Has the veins free and veinlets forked. It includes

\section{NEPHRODIUM THELYPTERIS. (Nef-ro-de-um the-lip-ter-is.) \\ "MARSH BUCKLER-FERN." \\ PLATE XIII., No. 3.}

The normal form of this fern is found all over the North Temperate Zone, and was, no doubt, formerly much more common than now. The New Zealand form is what is called "var. squamulosum," on account of its being slightly scaly. It occurs also in South Africa. It is rather local in New Zealand, though more abundant than is generally supposed. This arises from its being sufficiently like other swamp ferns, particularly Polypodium pennigerum, to escape notice among them. Mr. Thomson says "it occurs only in the north end of the North Island from the Bay of Islands to Rotomahana, which is probably its most southerly habitat." It is, however, pretty common in all the swamps on the northern side of Cook's Straits, and I have seen it in similar situations inland up to about 25 ooft. elevation; but, of course, it dies out as the swamps are drained, since it only grows in the sphagnum moss and on the grass tussocks, and never anywhere but in swamps.

It has slender, widely-creeping, many-rooted rhizomes, from which rather distant fronds arise. The stipes is long, thin, erect, straw-coloured, or light brown above, and dark at the very bottom, and furnished with a few, scattered, pale brown or yellow scales, which often fall off as the frond develops. Rachis straw-coloured below, shading to green above; also slightly scaly when young. Frond rather broadly 
lanceolate, pinnate. Pinnæ usually sub-opposite, long. narrow, set almost at right angles to rachis, and deeply cut into rather broad, oblong lobes, with entire edges. These lobes get narrower as the sori develop, because the edyes curl over. Texture almost membranous; colour bright yellowish green; sori very small and rather far apart, in rows near the margin; involucres small, white, membranous, and kidneyshaped. The plant is also called "Nephrodium squamulosum," "Lastrea thelypteris," and "Lastrea palustris." It can be easily cultivated if taken up in a mass of the sphagnum among which it grows, and this is placed in a pot kept standing in water, and frequently syringed. A zinc pot, with holes 2 in. or 3 in. from the bottom, so as to retain water to that level, is the best.

The following are bi or tripinnate

NEPHRODIUM DECOMPOSITUM. (Nef-ro-de-um de-com-pos-it-um.) PLATE V., No. 7.

This fern occurs also in Norfolk Island, Australia, Tasmania, and the Chatham Islands. It seems to grow from end to end of New Zealand, and though abundant where it occurs, is at the same time local. I have never seen it more than $1000 \mathrm{ft}$. above the sea, though I have met with it often below that level, both on flat ground and hill-sides. It grows very freely under cultivation, and produces many seedlings. It likes rich soil, but does not send roots to any depth.

It has rather thin creeping rhizomes, spreading over large patches of ground, and producing numerous fronds, sometimes three feet high. The stipes is long, rather slender but stiff, yellow or brown, downy above and scaly at base. Rachis also downy. Fronds broadly rhomboidal, tri-pinnate. Pinnules stalked or narrowly sessile, oval or lanceolate, and cut into shallow, pointed lobes. Sori numerous, nearer margin than costa. Involucres white membranous and kidney-shaped. Colour yellowish green: texture herbaceous, sometimes downy underneath. Also called "N. Pentangularum" (a most appropriate name), "Aspidium decompositum," "A. microsorum," "A. Shepherdi," "A. acuminatum," and "Lastrea decomposita."

NEPHRODIUM GLABELLUM. (Nef-ro-de-um gla-bel-lum.)

PLATE VI., No. 3.

Somewhat resembles the last, and was for a long time classed merely as a variety of it. It occurs in Australia, Fiji, and Tahiti as well as in New Zealand. It is found in the bush throughout the Colony, being far more common than N. decompositum; but like it, not ascending to high levels, though I have seen it certainly up to I 500 feet elevation, and I think higher still. It is very easily cultivated, and produces hosts of seedlings. It likes rich mould and a fair amount of shelter. Its main difference from $\mathrm{N}$. decompositum is that it has a stout erect rhizome, bearing a crown of erect fronds sometimes fifteen to eighteen inches high. Stipes variable but generally long, erect, 
slender but stiff, reddish brown, scaly at base but smooth above. The stipites of the lower fronds generally start out horizontally from the rhizome, and then turn upwards. This no doubt gave rise to the idea that they sprang from slightly creeping rhizomes. Rachis smooth and narrowly winged. Frond similar in form to that of $\mathrm{N}$. decompositum, but narrower, and with the whole foliage more sessile, the costæ of the pinnæ being winged throughout. Texture more coriaceous: colour dark olive-green. Sori half-way between costa and margin of pinnules. Involucres white, membranous, and very distinctly kidney-shaped. It is also called "N. decompositum var. pubescens," "N. decompositum var. microphyllum," "Lastrea davallioides," "Lastrea glabella," and "Aspidium glabellum."

\section{NEPHRODIUM VELUTINUM. (Nef-ro-de-um vel-u-ti-num.)}

\section{"DIRTY FERN."}

\section{PLATE XX., No. 2.}

This species is confined to New Zealand, and is found in forests all through the Colony, though more abundant in the North Island, where it often grows over three feet high. It only grows on hill sides or other dry situations, and usually in light bush, and is more local than the other sorts. I think, too, it is confined to lower levels, as I never remember seeing it more than 800 feet or so above sea-level. It is also called "Lastrea velutina," and "Aspidium velutinum."

It has a stout erect rhizome, sometimes rising an inch or two above ground, and bearing a crown of few fronds, which at once attract notice, not only by their size, but by their reddish-brown and velvety appearance. The stipes is rather long, stout, erect, scaly at base, and covered with brown down above. Rachis also brown and downy. Frond very broadly rhomboidal, tri-pinnate. Lowest pinnæ much widened on lower side, upper ones lanceolate. Pinnules rather long, oval, large, and somewhat deeply cut into rounded or pointed lobes. Texture herbaceous and covered with short down, giving the whole plant a velvety appearance (whence the name); colour very brownish-green, with a tinge of red. Sori numerous but small. Involucres hairy. It is very easily cultivated, particularly if taken up when young, and planted in sandy soil mixed with leaf-mould, and sheds many spores.

\section{NEPHRODIUM HISPIDUM. (Nef-ro-de-um his-pid-um.) \\ THE "HAIRY FERN." \\ PLATE III., No. 3.}

This is the commonest of the New Zealand Nephrodia, and occurs also in Victoria. It is also called "Polystichum hispidum," "Polypodium setosum," "Aspidium hispidum," "Lastrea hispida," and "Aspidium setosum," though it is very widely different from the Japanese plant, which bears the last name. Like the preceding one, it grows on hill sides, rather than on flat ground, but occurs in heavier 
bush. There are two forms of it. The general form has widely-creeping, stout, scaly rhizomes, sending up numerous fronds about eighteen inches high. Stipes long, stout erect, dark-coloured, and thickly covered with dark bristly hairs. Rachis and costæ similarly hairy; the latter winged. Frond triangular, bi or tri-pinnate. Pinnules sessile above, stalked below, oval or lanceolate, and deeply cut into long, narrow, pointed lobes, inclining much upwards. Colour glossy dark olive-green, slightly variegated; texture coriaceous. Sori numerous and near to edges. Involucres white, membranous, kidney-shaped and distinct.

The other form is a larger and much less hairy plant, often three feet high, and creeps very little; in fact, for several years it remains merely a tufted plant; and even when the creeping rhizomes form, they take a long time to outgrow a twelve-inch pot, and meanwhile send up many fronds. Both forms are easily cultivated, provided the plants are procured young, and planted in sandy soil and leaf-mould, but they need shade and a moist atmosphere

\section{SUB-GENUS EUNEPHRODIUM (Yu-nef-ro-de-um),}

Has the lower veinlets of contiguous groups united. It includes

\section{NEPHRODIUM MOLLE (Nef-ro-de-um mol-le), \\ PLATE XXIII., No. 5,}

Which is said to be common in the tropical parts of Africa, Asia, and America, as well as in Australia. In New Zealand it only occurs, for certain, in the volcanic districts, though it was reported from Whangarei by Mr. Mair. My plants came from Tokano, at the south end of Taupo Lake, and I have seen specimens from near Tapuaeharuru. Mr. Thompson mentions the banks of the boiling river "Otumakokori," at the foot of the Paeroa Range as another site, and it was said also to grow at Rotomahana, but if so, must have been destroyed by the volcanic eruption of June roth, 1886 . It is also called "Polypodium molle," "Aspidium molle," "A. nymphale," and other names. It grows well in a greenhouse and even indoors in the North Island, but would probably need more protection from the winter cold farther south. It likes sandy soil, with plenty of moisture to the root, is not particular about much shade, and is often three feet high.

It has creeping rhizomes sending up clusters of few fronds at short intervals. Stipes long, only moderately stout, yellow or green, and woolly, particularly when young. Rachis also green and woolly. Fronds oblong or lanceolate, pinnate, the lowest pinnæ being usually deflexed. Texture very softly herbaceous and downy, (whence the name, which means "soft"); colourbright yellowish green. Pinnæ stalked, long-lanceolate, opposite, and cut moderately deeply into rounded or sub-falcate lobes. Sori small, in one or two rows between costa and margin. Involucres small, white, membranous, and soon hidden by the capsules. I lately saw a plant of this fern, in 
which the stipes was divided into several branches, each of which was terminated by a fan-shaped mass of cresting. It had been produced under cultivation in England.

\section{NEPHRODIUM UNITUM. (Nef-ro-de-um u-ni-tum.)}

PLATE XXIII., No 1.

This is another typical fern, found in the hot parts of both Hemispheres, and in Australia and Polynesia. It also only occurs in the volcanic districts of New Zealand. It used to be abundant beside the hot stream which flowed from Rotomahana into the Tarawera Lake, and I brought my plants from there only a few weeks before the eruption of $\mathbf{I} 886$, which must have overwhelmed the parent ones. The fern is also reported from beside hot-springs at Maketu, as well as from Otumakokori and Waipihi, near Taupo. It grows well in a greenhouse, some of my plants producing fronds three feet high. They grow in pumice-sand mixed with a good deal of leaf mould. This fern has also stout creeping rhizomes, sending up clusters of few fronds at short intervals. Stipes long, brownish or yellow, smooth or only deciduously scaly at base. Rachis also smooth. Frond oblong, pinnate. Pinnæ in pairs, stalked, long, narrow and tapering, and all pointing much upwards, cut into tooth-like lobes. The lower ones have the lowest lobes cut nearly, or quite, down to the costa, so as to be partially bi-pinnate. Texture coriaceous, glossy above, slightly downy below. Colour bright green, inclining to dark. Sori placed in a row just within the margin, and so large and numerous as to be almost confluent. Involucres small and soon disappearing. I have noticed that the texture becomes softer under cultivation, more like N. molle. The fern is also called "N. propinquum," "Aspidium unitum," "A. gongylodes," and "Polypodium unitum."

\section{GENUS NEPHROLEPIS. (Nef-ro-lep-is.)}

From " nephros" a kidney, "lepis" a scale: has simply pinnate coriaceous fronds. Sori round, arising from tip of the upper branch of a vein, generally near the edge. Involucres kidney-shaped or nearly round. Veins free. Pinnæ articulated at base, and often very deciduous in dried specimens. Fronds have white chalky-looking dots on upper surface. Plants of this genus are found all round the world, within the tropics, and extend a short distance north and south of them. The only New Zealand species is

\section{NEPHROLEPIS CORDIFOLIA. (Nef-ro-lep-is cor-dif-o-le-a.)}

PLATE XX., No. 3.

This fern is found all through Tropical Africa, from the Guinea Coast to Zambesi land; in Asia and Polynesia, from North India and Japan, southward to Australia and New Zealand; and in Central America, from Mexico and Cuba southward to Brazil and Peru. In New Zealand it is only known to occur at Otumakokori and near Tapuaeharuru, both in the volcanic region East of Taupo Lake. The Rev. W. 
Colenso disputes the plant being the real N. cordifolia, and names it "N. flexuosa," on account of some trivial differences between it and the typical $\mathrm{N}$. cordifolia. It is also called " $\mathrm{N}$. tuberosa" (because in some countries the tubers on its roots are large enough to be collected as an article of food), "A. pectinata," "Aspidium cordifolium," and "A. Tuberosum." It is easily cultivated in a greenhouse, and I grew it for some years in a room. It likes light soil, and plenty of watering, but is apt to have a shabby appearance, owing to the pinnæ falling off and leaving the rachis bare. The fronds, too, are very often narrowed in the middle, as if they had intended to stop growing, and then started on again. I think this probably arises from changes of temperature occurring during the growth of the frond.

This fern has creeping wiry rhizomes, which produce tubers and crowns of fronds at intervals. The stipes is short, rather stout, erect, brown, and slightly scaly. Rachis also stout and brown, smooth, but with a scale here and there. Frond extremely long and narrow, pinnate. Pinnæ stalked, close-together, oblong, with rounded ends and rather widened bases. Edges entire or very slightly crenate in fertile pinnæ. The pinnæ are connected with the rachis by a joint, and thus are very liable to break off. It often happens that some of the lower pinnæ have thus fallen off before the apex of the frond has unrolled itself, and they are very apt to drop off in drying, and spoil the look of the specimens. Texture almost membranous; colour shining yellowish green. The position of the sori is marked by raised dots on the upper surface, and these are often white or nearly so. Sori few, kidney-shaped, and placed almost half way between the costa and edge, with the rounded side towards the apex of the pinna. Involucres also kidney-shaped, large and membranous.

\section{TRIBE POLYPODIÆ (Pol-ly-po-de-æ)}

Has the sori on the backs of lobes, round or rarely oblong, not more than twice as long as broad.

\section{GENUS POLYPODIUM. (Pol-ly-po-de-um.)}

From "polus" many, "poda " feet, so called because the European Polypody has a creeping rhizome, sending down many short roots. This is the largest genus of any, and includes plants of two different modes of growth, each series including a number of species of each of the different kinds of venation, and from all climates.

What is called the "Desmobryoid" series has the habit and mode of growth of Aspidium, i.e., has the stems contiguous to the caudex, and the sori always on the middle of veins.

The sub-genus "Phegopteris" has venation like Lastrea, i.e., veins all free. It includes 


\section{POLYPODIUM PUNCTATUM. Pol-ly-po-de-um punc-ta-tum.}

PLATE XV., No. 3.

This plant, in one form or other, occurs in North India, eastward to Ceylon and the Sandwich Islands, Japan, and thence southward, through the Philippines and New Caledonia, to Australia, New Zealand, and Tristan d'Acunha; in Africa, from St. Helena eastward to Bourbon, and in America, from Columbia southward to Chili. It occurs in two very different forms, which are classed in the Synopsis as P. punctatum, and var. B. rugulosum, but it is stated that Mettenius regards them as distinct, and as we have both in New Zealand, I will describe them separately. They are both pretty common in the New Zealand forests, but prefer light to heavy bush, the large form occurring in wetter places than "var. rugulosum," which is more commonly found on hill sides, or on logs. Both are often found in the edges of bush, and even in clearings. It is also called "P. rugulosum," "P. Viscidum," "Phegopteris rugulosa," and "Cheilanthes ambigua."

The larger kind, which I take to be the true P. punctatum, has rather slender, dark, creeping, scaly rhizomes, from which scattered fronds arise. These are often five feet high, and I am assured that, in the rich bush soil N.E. of Mount Egmont, it has been met with fully seven feet high. The stipes is stout, long, erect, yellow or light brown, downy and rather sticky to the touch, and often densely clothed with long soft, light brown hairs. The frond is broadly triangular, tri or even quadri-pinnate, and very compact. Pinnæ sub-opposite or alternate. Pinnules oblong or oval, cut into rounded lobes of greater or less depth, and stalked or narrowly sessile. Texture herbaceous or softly-coriaceous, slightly furry above, and more so below; colour varying from yellowish to brownish green. Sori numerous on underside of lobes, a short distance from the edge, and often in two rows. This plant can scarcely be distinguished from some forms of Hypolepis tenuifolia; the only distinction being that, in the latter fern, the sori are situated at the bottoms of the indentations, and have the edge of the frond bent over them, while in $\mathrm{P}$. punctatum they are on the lobes, and farther from the margin.

The other fern which I regard as the true "var. rugulosum" is figured at Plate XXII., No. 2. It has also a slender creeping scaly rhizome, but of a darker colour, and the fronds springing from it are less scattered, and seldom, if ever, more than three feet long, including the stipes, which is short, comparatively slender, dark chocolate brown, covered with short down and very sticky. These latter characteristics also apply to the rachis. The frond is long, narrow, flaccid, oblong or ovatelanceolate, and only bi-pinnate. Pinnæ in opposite or sub-opposite pairs, far asunder, and pointing or curving upward. Pinnules more or less broadly sessile, oval, and deeply cut into rounded lobes. Colour always dark brownish green; texture herbaceous and very velvety. Sori as in the P. punctatum, but more numerous, and 
larger in proportion to the size of the frond. This plant approximates to "Hypolepis distans," from which it only differs in its thicker rhizome, velvety sticky stipes and rachis, velvety texture, and position of the sori; in fact, I have seen intermediat $\epsilon$ forms which were difficult to class. Like many other ferns with creeping rhizomes, both forms are difficult to cultivate from pieces of the rhizome, but young plants grow rea dily enough under conditions similar to their natural ones.

\section{SUB-GENL'S GONIOPTERIS (Go-ne-op-ter-is)}

Is distinguished by having the venation of Eunephrodium, that is, veins branching with lower veinlets of contiguous groups joining.

\section{POLYPODIUM PENNIGERUM. (Pol-ly-po-de-um pen-nid-ger-um.)}

PLATES XXV., No. 3, and XXVI., No. 3.

This fern is found only in New Zealand and the Chatham Islands, but is closely allied to a South American one. It is very plentiful throughout the Colony, except perhaps in Stewart's Island. It is inostly found in the lower parts of gullies, or along the margins of swamps; but may often be seen growing under a hedge in company with Lomaria procera with which it is confounded by the Maoris under the name of "Korokio." It is also called "Goniopteris pennigera," "G. Forsteri," and "Aspidium pennigerum."

It has a hard, erect rhizome, often rising as a caudex two to three feet above the ground (and I think occasionally far higher), and crowned with a few large fronds, sometimes six feet long. The stipes is short, rather thick but soft, brownish or yellowish green and shining, smooth except a very few scales at the base. Rachis also green, tender, and shining. Frond long lanceolate and pinnate. Pinnæ, long, narrow, very shortly stalked, and cut into rounded or bluntly sub-falcate lobes; auricled on upper side at base, the auricles overlapping the rachis, and making the pinnæ appear sessile, lower ones deflexed, upper ones generally curving upwards. Texture membranous, glossy; colour varying from dark to rather bright green. Sori numerous, small, round, nearer costa than margin. Veinlets of lowest lobes anastomosing, the rest free. This is a very easy fern to cultivate, but must be kept sheltered, as the foliage is so delicate that wind will break the fronds all to pieces. When growing on the margins of swamps, however, it becomes harsher, and strong enough to resist the wind somewhat.

A crested variety, called "var...Hamiltoni," after its discoverer, was found several years ago, near Napier, and quite lately a deltoid form, and a very remarkably crested one, have been gathered by Mr. Ellis, near Stratford, in the Taranaki District.

\section{THE EREMOBRYOID SERIES}

Is distinguished by having the stems articulated (that is jointed) at point of junction with the rhizome, and the sori generally, but not always, terminal on veins. 


\section{SUB-GENUS EUPOLYPODIUM (Yu-pol-ly-po-de-um)}

Has the veins all free. It includes the following groups:

$$
\text { GRAMMITIS GROUP (Gram-mi-tis), }
$$

Which has simple fronds with linear sori, includes

\section{POLYPODIUM AUSTRALE. (Pol-ly-po-de-um Aus-tra-le.) \\ PLATE XXII., No. I.}

There are either two distinct plants, or two distinct forms of one plant thus called, and stated in the Synopsis to occur in Australia, New Caledonia, Tristan d'Acunha, and the southern portion of South America and adjacent islands, as well as in New Zealand. The following synonyms are also given, viz:- "Grammitis Australis," G. Billardieri," "G. ciliata," "G. Rigida," "G humilis," and "Polypodium diminutum." The Synopsis says, "the fern has a creeping rhizome, forming a dense mass." Mr. Thompson says, "It has a "rhizome short, creeping, scaly, forming a dense tuft:'" H. E. S. L., " rhizomes short, creeping, scaly; fronds densely tufted :" while Dr. Hooker merely says it has the "fronds densely crowded." This last is the only one that fits the plant with which I have been familiar for many years, in the high country inland of Wanganui, and which has an erect rhizome, some times rising one or two inches above ground, and surmounted by a small dense tuft of erect fronds. These have no distinct stipes, but the fronds widen out at once from the articulated junction with the rhizome. They are simple, and generally merely long lanceolate, with entire or very slightly indented edges, but some widen gradually, and have a rounded end (both forms are shown in the Plate), fronds of both forms often occurring on the same plant. A midrib extends from end to end; and the sori form a succession of short lines on each side of it, and placed obliquely to it. Texture smooth and submembranous ; colour yellowish green. Inland of Waitotara, however, there is a plant similar in its general appearance, but slightly hairy, which is no doubt the variety called by Dr. Hooker "var. ciliata." This plant has slender, creeping, woolly rhizomes, from which tufts arise at intervals of an inch or two, and so overspread a small patch of ground, or surface of a log. Mr. Thompson describes the plant as growing "on tree trunks, rocks, etc.; but I have only seen either kind which I have described on the faces of banks, or rotten logs. Neither kind is easy to cultivate. The only chance is to lift a good lump of the earth, or rotten wood, with the plant.

Another plant has been found in Canterbury, by Mr. J. B. Armstrong, who named it "Grammitis pumila" (Plate XV., No. 1). It has an ordinary slender, creeping rhizome; and the fronds are smaller than in the other plants, and have only one sorus, and that at the end of the midrib. 1 believe it occurs on rocks, but I have not seen it growing. 
POLYPODIUM GRAMMITIDIS. (Pol-ly-po-de-um gram-mi-tid-is.)

PLATE XIV., No. 3.

This fern is found in Tasmania, Victoria, and the Chatham Islands, as well as in New Zealand. In the latter it occurs from end to end of the Colony from the coast up to about 3000 feet elevation. It is also called "Grammitis heterophylla," "Xiphopteris heterophylla," and "Ctenopteris grammitidis." It is often found in the New Zealand forests growing among moss on tree-trunks, and sometimes on logs. It lias a short, stout, erect, scaly rhizome, covered with a handsome tuft of fronds. Stipes short, brown, smooth, and slightly winged; in fact, merging into the frond itself. Rachis also smooth and brown. The frond varies greatly in shape, but is generally more or less ovate or lanceolate, an 1 aliways marely pinzatifid or pinnati-partite. Sometimes it is long and narrow, with shailow rounded lobes, the edges of which are entire. At others again, the lobes become long and narrow, either oblong or tapering, and decurrent on lower side. At others again, the lobes become longer still, and themselves lobed more or less deeply; and occasionally a plant is met with, whose fronds, or some of them, divide again. Often the lower part of the frond is comparatively simple, and the upper-portion is deeply lobed or branched. The texture, however, is the same in all cases, viz:-thickly coriaceous, and the colour dark, brownish, rather glossy green, with inconspicuous veins. Sori oval or oblong, numerous, and placed on the undersides of the lobes, mostly towards apex of frond. It is not an easy fern to cultivate, as when its roots are detached from the bark on which they grow, they seem to have a difficulty in again attaching themselves to anything, or in absorbing nourishment from the material in which they are planted. Rotten bark and leat-mould are the best substances in which to plant this fern, and it must be kept in a glazed case, or under a bell-glass, till it is established. When it is so, it will require little attention besides occasional watering. It is so handsome a little fern that it is worth some trouble to get it to grow.

\section{ARTHROPTERIS GROUP (Ar-throp-ter-is)}

Has creeping or climbing rhizomes, and pinnate, often pendulous fronds. One New Zealand fern belongs to it, r'iz:-

\section{POLYPODIUM TENELLUM (Pol-ly-po-de-um te-nel-lum), PLATE IV., No. 4,}

Has long, rather slender, hard, creeping rhizomes, which spread about above the surface of the ground, and climb trees by means of their rootlets. Stipes, short, brown and smooth. Rachis also brown and smooth. Fronds distant, long, narrow, lanceolate, pinnate. Pinnæe distant, alternate, stalked, long-oval or lanceolate, with edges entire at first, but very slightly crenate or lobed as the sori develope. Sori small, round, and placed one in centre of each lobe. Texture thinly coriaceous : 
colour darkish green. Also called "Arthropteris tenella," and "Polypodium filipes."

This fern is found in New Caledonia, and Australia, as well as in New Zealand. It is pretty common in the North Island, in forests, but is only reported from Banks' Peninsula in the Middle one, and not at all from Stewart's Island. It is very easily cultivated, as any bit of the terrestrial rhizomes will grow, if pegged down among leafmould and dead leaves. To see the plant properly, however, a young tree of some kind should be planted with it, and the creeping rhizomes guided to it, and allowed to climb. It thrives best in a moist atmosphere.

\section{SUB-GENUS CAMPYLONEURON (Cam-pil-o-nu-ron)}

Has the primary veins distinct, extending from the midrib to the edge, and connected by parallel straight or curved transverse veinlets. Areolæ containing two or more sori. The free veins all directed to the edge. It includes the Niphobolus group, the ferns of which have their under surface matted with woolly or cottony tomentum. To this belongs

\section{POLYPODIUM SERPENS (Pol-ly-po-de-um ser-pens) \\ PLATE VI., No. 9,}

Which is found from Australia eastward to the Society Islands, as well as in New Zealand and Chatham Islands. It is also called "Polypodium rupestre," "P. stellatum," "P. elæagnifolium," "P. confluens," "Niphobolus rupestris," and "N. confluens." It is very abundant throughout New Zealand, and is found on tree-trunks both in forests and in the open; on roots, on rocks, and sometimes on the ground. It ascends to 3000 or 4000 feet, and cannot be mistaken for any other fern. It will grow almost anywhere and anyhow.

It has a rather stout, scaly, fleshy, reddish brown, widely-creeping rhizome, which clings to the bark of trees and other objects, and bears scattered fronds of two kinds. The stipes of both is rather long in proportion to the frond, round, stiff, and fleshy. The barren fronds are oval or almost round, very thick and fleshy, smooth bright green above, and covered with thick white or reddish tomentum below. The hairs composing this tomentum have stellate ends. Fertile fronds much longer and narrower, varying from ob-ovate to lanceolate, and lanceolate with rounded apex. Colour and texture like the barren fronds. Sori numerous, round, somewhat irregularly arranged, and often confluent, so as to cover the under surface of the frond, particularly towards the apex.

\section{SUB-GENUS PHYMATODES (Fi-mat-o-dees)}

Has the areolæ fine, copious, irregular; free veins spreading in all directions. Sori various in position, but generally on back of united veinlets. Several New Zealand ferns belong to it, viz: 


\section{POLYPODIUM CUNNINGHAMII. (Pol-ly-po-de-um Cun-ning-ham-e-i.)}

PLATE XV., No. 5.

This fern, which is also called "Polypodium attenuatum," and "Dictymia lanceolata," is found in the New Hebrides as well as in New Zealand. In the latter, however, it seems pretty nearly confined to the North Island, where it is fairly common, while South of Cook's Strait it has only been reported from Nelson and Banks' Peninsula. It grows generally on tree-trunks in huge mats; but occasionally on rocks and still more rarely on damp ground. It has soft, tender, woolly, creeping rhizomes, from which tufts of a few fronds each arise. The stipes, such as it is, is smooth and wiry, and a wing begins from its very base and gradually widens into the long, narrow, simple, lanceolate frond. The edges are entire, and veins anastomosing and distinct. Sori very large, round, or slightly oval, forming a line rather nearer to the rachis than to the edge. Texture almost membranous : colour bright, rather glossy green. It is easy to cultivate in rotten bark and leaf-mould.

POLYPODIUM PUSTULATUM. (Pol-ly-po-de-um Pus-tu-la-tum.) PLATE XVII., No. 2.

This fern, which is also called "Polypodium scandens," "P. membranifolium," "Phymatodes pustulata," and "Pleopeltis pustulata," grows throughout Australia, Norfolk Island, and the Chatham Islands, as well as in New Zealand. It abounds in the North Island, and northern end of the Middle one, up to 2000 or 3000 feet, but becomes scarcer farther South. The fronds emit a sweet scent, somewhat like new hay, when dry, and hence were used by the Maoris to scent oil for the anointing of their hair. It creeps on the ground, but ascends trees to a considerable height, clinging on by its rootlets. It is easily cultivated, in bush soil ; but to show it properly, it needs something to climb.

The rhizomes are long, branching, rather thin, tough, and thickly hairy. Stipes smooth, short, or almost wanting, as its wing merges into the web of the frond itself. Rachis also smooth. Fronds sometimes very long, narrow, linear, lanceolate; and at others widening out irregularly into lobes, of greater or less length, set at about right angles to the rachis. Texture thin, almost membranous, colour very dark green. Sori round or slightly oval, in one row rather more than half-way from the mid-rib to the margin.

\section{POLYPODIUM BILLARDIERI. (Pol-ly-po-de-um Bil-lar-de-er-i.)}

$$
\text { PLATE II., Nos. 4, 4a, 4b. }
$$

It is also called "Polypodium scandens," "P. diversifolium," "Phymatodes Billardieri," and "Niphobolus glaber." It occurs also in Australia, Tasmania, and the Chatham, Auckland, and Campbell Islands, as well as in New Zealand, and a very closely allied plant grows in New Caledonia. It grows indiscriminately on the ground, on tree-trunks, logs, and rocks, both in dense bush and in the open, and is very easily 
cultivated, needing little moisture or shelter, and producing fronds up to two feet high.

It has long, branching, thick, fleshy rhizomes, of a bright green colour, dotted over with dark scales, and often spreading over an area of many square yards. Stipes variable in length, strong, smooth, dark-coloured, and furnished above with a wing, which gradually widens out into the web of the frond. Rachis glossy and brown. Fronds vary greatly in shape. Sometimes they are ovate-lanceolate (No. 4 on plate) and retain that form even when fertile. At others they become very much widened out into long bluntly-pointed lobes, which are very broad in the barren fronds (No. 4a on plate). In this state, the fertile fronds (No. $4 \mathrm{~b}$ on plate) are much larger, with more numerous and narrower pinnæ, which sometimes branch again into a number of similar lobes, and so produce an extremely handsome truly bi-pinnatifid frond. Texture coriaceous : colour bright green with the anastomosing veins showing very distinctly, which makes it rather a favourite plant with those who grow ferns merely as ornaments for the house. Dwarfed forms occur at high levels, and on rocks, but the smallest is one that is found in the Canterbury District. Its rhizomes are not more than a sixteenth of an inch thick, and the fronds (stipes included) are not more than from a half to one and a half inch long. They are almost all lanceolate, only a very few being slightly indented into lobes on either side.

\section{POLYPODIUM NOVÆ ZELANDIÆ. (Pol-ly-po-de-um No-væ Ze-land-di-æ.) PLATE XXVII., No. 3.}

This fern is confined to New Zealand. 1 was the first person who discovered it, in January, 1876 , in the red-birch forest about 15 miles south-west of Ruapeliu, and it was found by Mr. T. F. Cheeseman in the following year, on the Pirongia Mountain, between the Waikato River and the West Coast of the North Island. These two points mark its extreme north and south range, in the forests West of Ruapehu and Taupo Lake, to which it was believed to be confined; though a plant, supposed to be the same, has lately been reported from the birch country adjacent to the Waikare lake.

It has stout, hard, creeping, very scaly rhizomes, as thick as a man's little finger, growing almost exclusively on trees; I think only on the red-birch, for though I have spent many months in the forest in which it occurs, I never saw it on any other tree, or on the ground, and only occasionally on fallen rotten birch trees. The stipes is rather long, dark brown, and shining; and the rachis the same, and rather narrowly winged throughout. Frond oblong, pinnate. The pinnæ are numerous, and arranged in opposite pairs (sometimes twenty or more pairs in a frond four feet long), long, narrow, lanceolate, decurrent on lower side, pointing obliquely upwards, and often slightly crenated in the edges, when the sori are developed. Texture thinly coriaceous : colour dark green, with indistinct anastomosing veins. There are no barren pinnatifid fronds, and simple ones only on very young plants. Sori large, in one row on each side of costæ. I have tried repeatedly, in vain, to grow this fern, even 
bringing home large slices of the birch bark, with young plants on them, but I always found that the plants died as the bark decayed, so that I fancy the fern is a parasite, sucking the birch sap.

\section{GENUS NOTHOCHLÆNA (No-tho-kle-na),}

From "nothos," spurious; "chlaina," a cloak; so named on account of the hairy edges sometimes partially covering the sori, and forming a sort of spurious involucre. It has large sori, at first round or oblong, but soon confluent into a continuous line without involucre, but often with deflexed edge. Veins free. Differs from Cheilanthes only by absence of distinct involucres, and connected with that genus by gradual intermediate stages, so as to make it doubtful whether they are not merely forms of one class of plants. Only one ferr of this genus occurs in New Zealand, viz:

\section{NOTHOCHLANA DISTANS (No-tho-kle-na dis-tans),}

\section{PLATE XVI., No. 3,}

Which is found in Australia and New Caledonia, as well as in New Zealand. So far as is known, it occurs only locally in the Colony, but as it is a small plant, and shrivels up in dry weather, it is possibly more common than is generally supposed. It grows on the volcanic rocks about Auckland, on Ruapehu, Mt. Egmont, Kapiti Island in Cook's Straits, the Port Hills near Christchurch, and other parts of the Canterbury District, where it is said to ascend to 3000 feet elevation, (even higher on Ruapehu and Egmont), while at Mt. Eden, near Auckland, I saw it within 400 feet of sea-level and at Kapiti it grows close to the beach. In all cases, however, it occurs on dry open places, and very generally in crevices of the rocks.

It has slender, woolly, creeping rhizomes, from which tufts of few fronds arise at short distances. Stipes long, stiff, red, or chocolate-coloured, with a good many narrow, dark-red scales scattered over it. Rachis and costa same colour, and very scaly. Fronds long, narrow, oblong, obtusely-pointed, bi-pinnate. Pinnæ, distant, in opposite pairs, pointing slightly upwards. Pinnules also in pairs, more or less deeply lobed, and having deflexed margins. Sori in a line (sometimes in two) just within the margin, and almost confluent. Texture coriaceous and hairy; colour dark olivegreen. It is a most easy fern to cultivate in sandy soil, and very soon sends up fresh tufts all over the pot. It will also stand an amount of drought that would kill almost any other fern. Even when it has been neglected, and is to all appearance withered and dead, a good watering will cause new fronds to spring up in a few days, so that I wonder the plant is not more common, and, as I have already said, I fancy it really is so, but escapes notice, from fern-lovers generally collecting such plants in dry weather, when this is withered.

GENUS GYMNOGRAMMA (Gym-no-gram-ma), So called from the naked linear sori ("gymnos," naked; "gramma," a line); has sori 
arising from the veins all over the under surface of the fronds, linear or linear-oblong, simple or forked.

\section{SUB-GENUS EUGYMNOGRAMMA (Yu-gym-no-gramma)}

Has the veins free, and the under-surface of the frond not powdery. It includes

\section{GYMNOGRAMMA POZOI. (Gym-no-gram-ma Po-zo-i.) PLATE X., No. 1.}

The typical form of this fern is found in the North of Spain, North Africa, the Coasts of the Mediterranean and other warm parts of the Northern Hemisphere; var. $\mathrm{B}$, otherwise "rutæfolia," i.e., rue-leaved, in Australia, Tasmania, and New Zealand, and a Chilian form, var. G "papaverifolia," i.e., poppy-leaved, with more deeply cut foliage, is also recognised. The New Zealand plant was first gathered near Cape Terawiti, by a Maori shepherd, who took it into Wellington, and it has since been found near " the Brothers" lighthouse at the entrance to Queen Charlotte's Sound, at D'Urville's Island, the Port Hills near Christchurch, near Oamaru, and in the Rangitata Country at the back of the Canterbury Plains, at an elevation of 3000 feet. It grows in crevices of the rocks, and as it is said to occur usually in company with Nothochlæna distans, I think it is also probably overlooked by collectors. The late Mr. T. H. Potts considered the Canterbury plant to be different from the Australian one, and proposed to call it "G. alpina," and it is certainly a far larger and differently cut form from that, of which I have seen specimens, from Australia and D'Urville's Island, though otherwise similar. This fern has a short, stout, erect, rhizome, crowned by a tuft of from three to twenty or more fronds, sometimes six inches high. Stipes long, thin, yellowish and hairy. Rachis the same. Frond oblong, pinnate. Pinnæ far apart, short, stalked, fan-shaped, and more or less deeply divided into linear divisions radiating from the stalk. Texture thinly coriaceous; colour dull green. The plant is quite unmistakeable, as its whole surface, both above and below, is densely clothed with soft white hairs. Sori in lines radiating from stalks of pinnæ, brown. It is easily cultivated, requiring little moisture in any form. It is also called "G. rutæfolia," "G. papaverifolia," "G. subglandulosa," "G. Alpina," and "Grammitis rutæfolia."

\section{GYMNOGRAMMA LEPTOPHYLLA. (Gym-no-gram-ma lep-to-fil-la.)} PLATE XVI., No. 6.

This most lovely little plant, with only two others, is placed by the botanist, Link, in a separate genus, under the name of "Anogramma," because they are annuals. G. Leptophylla is very widely distributed, being found in the Azores, Madeira, the Canary Islands, Jersey, Barbary, the Shores of the Mediterranean, Abyssinia, Cape Colony, Persia, the Neilgerries, Australia, Tasmania, and the Andes from Mexico southward to Ecuador, as well as in New Zealand. In the Colony it is rare, and getting 
scarcer. It used to be plentiful about Auckland, but seems to have disappeared from all but one locality. It also used to occur in two or three places near Wellington, but I believe the sheep have eaten every bit of it. It held its ground in one place for some years, as it was just above the reach of Merinos, but when larger sheep were introduced they soon demolished it. Mr. Colenso says it still occurs sparingly at one place near Napier, and it certainly does so on the Port Hills between Christchurch and Lyttelton, where it is said to be tolerably plentiful in some seasons, and almost absent in others. Mr. Thomson mentions the Thames, some other parts of Canterbury, the Upper Clutha near Cromwell, and the vicinity of Dunedin, as localities where it may still be found, but no doubt the sheep will soon banish it. It is an annual plant, growing up about February, lasting through the winter, perfecting its fronds in the spring, and dying as soon as the warm, dry summer weather begins. Thus, if eaten off, or otherwise prevented from shedding its spores for a single year, it disappears from the locality. Every lover of ferns, therefore, should make a point of growing some every year, and scattering the spores where they would be out of the reach of sheep. Its delicate beauty will well repay the trouble. Though it ordinarily grows in crevices of rocks, yet it is not particular as to soil, and would soon be plentiful if it only got leave to live. It rarely exceeds three or four inches in height.

It is just a tufted plant, with no noticeable rhizome, and only produces from three to about six fronds. The stipes is rather long, and of a bright shining brownish red colour, which, in the rachis, gradually merges into the green of the frond. Frond oval or triangular, bi or tri-pinnate. Pinnæ oval or fan-shaped, cut into oblong lobes. Texture quite glossy and membranous : colour bright yellowish green. Sori radiating from the stalks of the pinnæ, along the lobes, and at last almost covering the undersurface of the frond with brown fructification.

\section{SUB-ORDER OSMUNDACEZE (Os-mun-da-ce-æ)}

Has two-valved capsules opening across the top and furnished with a short horizontal ring.

\section{GENUS OSMUNDA (Os-mun-da)}

Has the sori distinct from the leafy part of the frond, and forming a panicle made up of copious thyrsoid clusters.

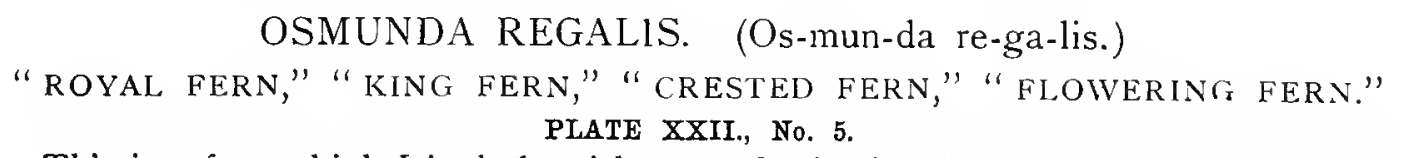

This is a fern which I include with some hesitation, because, though it has been found in one locality, there seems to be a doubt as to how it got there. Perhaps the best way will be to state the facts. Dr. Curll, who for many years resided at Rangitikei, always asserted that the Osmunda grew at one spot beside the river, during 
the early days of the settlement, but had been destroyed by the clearing of the ground and by the cattle. Though the Doctor was generally a good authority on botanical matters, and occasionally contributed papers to the Philosophical Transactions of the New Zealand Institute, it was generally thought that, in this matter, he was wrong, and had probably mistaken some fern, with somewhat similar foliage (possibly "Asplenium umbrosum," "Pteris incisa," or even some form of "Lomaria procera" with the terminal pinnæ alone fertile), for the Osmunda. Whatever the plant was, it seemed to have disappeared. In $\mathrm{I} 885$, however, I accidentally found a small plant (a mere seedling) at the place which the Doctor had indicated, and two years later, when my plant had proved itself, by producing fertile fronds, a search of the locality endbled me to get several more. It is evident, therefore, that, in some way, the Ozirunda spores had reached the spot. It has been suggested that, as Dr. Curll was in the habit of importing plants and seeds, he may have sown the spores; but it seems to me that if he had taken the trouble to get spores from England, he would have sown them beside the stream in his own garden, where he could protect them, rather than on the flooded interval of a river, on another man's land, more than a mile from his residence, and where the young plants would be exposed to the attacks of sheep and cattle. A more likely theory is, that the spores of the original plants were accidentally introduced with grass seed, at the very outset of the settlement, and had grown up when Dr. Curll first saw them, though they were destroyed as sheep and cattle became numerous. I do not myself, however, see any reason for starting either theory. The Synopsis gives the following habitats for the fern, viz:- " Northern Europe and Asia from Sweden to Siberia, Japan, the Azores, Barbary, the Himalayas, Bombay, Neilgherries, Cochin China, Hong Kong, Mascaren Island, Zambesi-land, Angola, Natal, Cape Colony, and America from Canada and the Saskatchewan to Rio Janeiro." Surely there is nothing wonderful in a plant which grows on three sides of us, at the Cape, Bombay, and Rio Janiero, occurring in New Zealand also; and as the Rangitikei plant differs from the European one in several important respects, I feel pretty sure that Dr. Curll's statement was correct, and that the fern was really indigenous. The differences which I have observed between the Rangitikei plant and the European one are as follows: The first indication of reviving vitality in the European plant, in the spring of the year, is its producing some very small preliminary fronds, quite different from those which are afterwards developed, and which do not spring up till several weeks later. The New Zealand plant does not produce these preliminary fronds. In the European plant the fertile fronds grow erect, while the large barren ones, which do not spring up till two or three weeks later, droop outwards. The New Zealand plant produces both kinds of fronds at the same time, and they all droop outwards alike. Again, the fertile pinnæ of the European plant grow ere?, parallel or nearly so to the rachis, but those of the New Zealand one are set nearly at right angles to the rachis. 
The New Zealand plant, too, produces fertile fronds at not more than three or four years old, while my experience indicates that the European one takes twelve or fifteen years to do so. It seems to me that these differences of growth show pretty plainly that the New Zealand plant is a distinct variety from the European one. The only lingering doubt in my mind arises from the fact that other strange ferns have been found in the same locality. I have seen a few plants of "Horse-shoe fern," "Marattia fraxinea," growing only a few hundred yards distant, though I know of no others within seventy or eighty miles; and the late Mr. Francis Williamson, of Wanganui, a very reliable authority, assured me that the Auckland fern "Lygodium articulatum" used to grow in a neighbouring patch of bush, till it was cut down. These facts indicate a possibility of some very early settler having taken the trouble to fetch ferns to the locality from a distance, though no one is known to have done so.

The name "Osmunda" is given to the European plant in consequence of a curious old legend, which relates that, during an invasion of the Danes, one Osmund, a ferryman at Loch Tyne, saved the lives of his wife and daughter, by rowing them to an island, and making them lie down among these ferns, while he was occupied all day and night putting the enemy across the loch. It only grows in very wet situations (at Rangitikei at the edge of a swamp), and is very easily cultivated in good soil, with abundance of water; in fact, it is well to keep the pot standing in water. It dies down in early winter, and comes up again in spring. This is a very handsome fern, growing in England usually three to four feet high, and sometimes eight or ten feet. It has a stout, erect rhizome, and an immense number of hard matted fibrous roots. The New Zealand plant seems to have far more even than the English one, and they have a greater tendency to rise above ground. This rhizome sometimes, in the English plant, becomes a caudex one to two feet high. The stipes is long, yellowish or reddish, stout, and when young sparingly scaly, and covered with soft brown, or yellow down. Rachis the same, but the scales and down generally drop off as the frond develops. The fronds are of two kinds, barren and fertile. The barren ones are broadly lanceolate, and bi-pinnate. The pinnules are stalked, ovate-lanceolate, distinctly veined, thirily coriaceous, and of a bright shining green. The fertile fronds are of the same shape, but a few of the top pinnæ have the pinnules contracted into mere double lines of large sori, consisting of many capsules, and looking very like spikes of small flower-buds, whence the name "flowering fern."

$$
\text { GENUS TODEA (To-de-a), }
$$

Called after a German Botanist named Todes. It has the sori on the back of leafy portion of frond.

$$
\text { SUB-GENUS EUTODEA (Yu-to-de-a) }
$$

Has the texture coriaceous. The only New Zealand plant of this genus is 


\section{TODEA BARBARA (To-de-a bar-bar-a), PLATE XXVI., No. 1,}

Which is found also in Cape Colony, Natal, Australia, and Tasmania, and occasionally grows eight feet high. Rhizome, erect, stout, fibrous, sometimes forming a caudex four or five feet high. Stipes moderately long, brown and smooth. Rachis also brown and smooth. Frond lanceolate, bi-pinnate. Pinnæ numerous, long, narrow, acute, and pointing slightly upwards. Pinnules numerous, sessile, long, narrow, oblong, slightly indented or serrated in the margins, bright glossy green and coriaceous. Sori slightly oval, placed close together in one line on each side of the midrib of the pinnule, and set slightly obliquely to it. They are confined to a few of the lowest pinnules on the lower pinnæ of the frond, being in this respect the very opposite of the "Osmunda."

This fern is also called "Todea Africana," "T. rivularis," and "Osmunda barbara." It is only found in the very North of the Colony, but is easily grown in a greenhouse or case, and was stated by the late $\mathrm{Mr}$. T. H. Potts to have been grown, for some years, in an open fernery, as far South as Christchurch. It is a very handsome fern; and from its large size, and bright shining green colour, always at once attracts the notice of strangers.

\section{SUB-GENUS LEPTOPTERIS (Lep-top-ter-is)}

Has a filmy texture like Hymenophyllum. The New Zealand plants are the following:

$$
\begin{aligned}
& \text { TODEA HYMENOPHYLLOIDES. (To-de-a hi-men-o-fil-lo-id-ees.) } \\
& \text { PLATE Iv., No. 3. }
\end{aligned}
$$

This beautiful fern is confined to New Zealand, where it occurs in sheltered damp forests all over the Colony, up certainly to 2000 feet elevation. It has a stout, erect rhizome, sometimes rising into a rather conical caudex or rootstock three or four feet high, crowned by a handsome tuft of fronds. Stipes variable in length, being longest in young plants, and shortest in old ones; brown, or brownish green, generally glossy. but occasionally slightly furry. Rachis smooth, and narrowly winged towards the top, Fronds bi-pinnate, and varying in form according to the age of the plant. At first they are somewhat broadly triangular, but as the plant grows older they become oblong. Later still, the lower pinnæ become shortened and deflexed, so that the frond is ovatelanceolate. The pinnæ are numerous, stalked, linear-lanceolate, and so close together that their segments overlap. Pinnules also numerous, crowded, shortly-stalked, and cut almost to their mid-rib into very narrow linear lobes. These generally lie flat, but in old plants they often turn upwards very considerably. Texture membranous : colour dark shining green, which is very apt to turn almost black in drying. Occasionally plants are found which have the texture very much thickened, though still retaining its transparency. The fronds of these are sure to turn black in drying. The sori are so irregular that the capsules seem thickly scattered over all the middle portion of the 
frond towards its base. This fern can easily be grown from young plants carefully lifted, but it is difficult to transplant a large one safely. In the North Island, it will grow in a well-shaded and sheltered damp fernery, but far better in a case; though Mr. Thomson seems to say that, in the cool climate of Otago, it merely needs "a shady spot protected from wind." It is also called "Todea pellucida," "Leptopteris hymenophylloides," and "L. pellucida."

\section{TODEA SUPERBA. (To-de-a Su-per-ba.)}

"PRINCE OF WALES' FEATHer," "CHENIlle FERn," AND "CRAPE FERn." PLATE XXI., No. 4.

This is confined to New Zealand and southward to the Auckland Islands. It appears to be absent from the north end of the Colony; but from about Cambridge on the Waikato, and Te Aroha on the Thames, southward, it occurs everywhere, in bush land, at elevations of 2000 to 3500 feet, descending nearly to sea-level near Invercargill. It is also called "Leptopteris superba." Rhizome erect, forming a conical rootstock, sometimes three feet high, capped by a crown of numerous fronds, often two, and sometimes four feet long. In the late spring this plant looks lovely. The previous year's fronds, perhaps ten or twelve in number, are beginning to droop, but still retain their semi-transparent dark-green colour, and above these there are an equal number of young sub-erect fronds of bright delicate green, contrasting beautifully with the old ones. Stipes, short, naked or velvety, brown or brownish green. Rachis. same colour, but always more or less velvety. Frond varying in shape with age of plant. At first the fronds of young plants cannot be distinguished from those of Todea hymenophylloides, and this similarity continues till the fronds assume the oblong stage. They then seem to change suddenly into a broad-lanceolate tri-pinnatifid form, which they retain permanently. The pinnæ are of the same shape as those of "Todea hymenophylloides, but the lower ones are shortened gradually to mere pinnules. Both pinnæ and pinnules are much crowded together, and the latter are cut into long linear pointed lobes, which all turn up and give the upper surface of the frond a mossy appearance. In some plants, however, these lobes are fewer, aud the pinnæ and pinnules less crowded, and in this case, though the general form of the frond remains the same, the lobes lie flat. This seems to be the plant known as "T. intermedia," but I have heard the same name applied to the form of "T. Hymenophylloides," with upturned lobes. In fact, the plants are so connected by these intermediate stages, and so alike when young, that I feel a doubt whether they are not merely high and low level forms of one fern. A great many people try to grow this fern, and almost invariably fail. To succeed, the plant must be taken up carefully with the whole of its roots intact, and it must be kept in a cool moist case. Exposure to a dry atmosphere, for even a few hours, will blacken all the points of the lobes, and spoil the look 
of the plant for the year. Even syringing the plant frequently will not save it ; in fact, the rapid evaporation afterwards seems to increase the mischief. To expect a fern to live after its roots have been all hacked away, as is generally done with plants brought from the West Coast and elsewhere, is utterly absurd, and equally so to expose one which only grows in an atmosphere saturated with moisture, and in the deepest shade and shelter, to the dry air of a room, or to sun and wind in a garden.

\section{GENUS SCHIZCEA (Skite-zœ-a)}

Has capsules sessile in two rows, which cover one side of close distichous spikes, which form separate fertile segments, at apex of fronds.

\section{SUB-GENUS EUSCHIZCA (Yu-skite-zœ-a)}

Has the fertile segments pinnate; frond terete or sub-terete, and capsules biserial

\section{SCHIZCA FISTULOSA (Skite-zœ-a fis-tu-lo-sa) \\ PLATE XIV., No. 5,}

Is found in Australia, Tasmania, New Caledonia, Chili, and Madagascar, as well as in New Zealand and Chatham Islands. It usually occurs on poor, cold, wet, clay land; but Mr. Thomson mentions having "gathered it, in a stunted condition, in peaty swamps in Stewart's Island, at the head of Paterson Inlet," and I can testify to its being abundant on the pumice flats about Rotorua, and growing luxuriantly in the immediate vicinity of the hot springs. It is particularly abundant near what is known as "the Lobster Bath," at Ohinemutu, the water of which turns the skin a bright red lasting for some hours. The fern varies in height up to twelve inches; but a smaller variety classed in the Synopsis as "S. Australis," and by Sir W. J. Hooker as "S. fistulosa, var. Australis," only one to two inches high, occurs in the Falkland and Auckland Islands, and I think will be found to grow in New Zealand at high levels. At all events very stunted forms do grow at the high elevations, and I think it likely that what Mr. Thomson gathered may have been it. The normal form is found here and there all over the Colony.

This Schizœa has no distinct stipes; in fact, it may be said to have none, or to be nearly all stipes, according as one regards it; as the whole frond consists of a slender, smooth, brownish-red stalk, not more than a thirtieth or a fortieth of an inch thick, rounded at the back and rather deeply channelled in tront, surmounted by a brush of linear segments, covered with capsules, and growing touching each other on one side of the stalk only. This brush is from a half to an inch long, by about an eighth of an inch broad. The fronds grow in clusters, sometimes of twenty or thirty, close together, from shortly-creeping scaly rhizomes. My own experience agrees with that of Mr. Thomson as to the difficulty of cultivating this fern. The plants which I brought from Rotorua seemed to do well for a time, but the young fronds were eaten 
off by small insects as fast as they appeared, and so the ferns died. There is no beauty in the plant, which looks more like a rush than a fern, but it is worth growing as a curiosity. It is also called "S. Valdiviana," and confounded with the next as "S. propinqua," and "S. bifida." The small form is also called "S. palmata," and "S. pectinata."

\section{SCHIZCEA BIFIDA. (Skite-zœ-a bi-fid-a.)}

PLATE XII., No. 3.

This fern is also found in Tasmania and Australia. In New Zealand it is met with occasionally from the Bay of Islands to Cook's Straits, but is not reported from the Middle Island. It used to be pretty plentiful among manuka scrub on the pumice soil of the Wanganui Valley, but is disappearing as the scrub is cleared. I have also found it on poor clay land, among stunted fern and manuka, at the North Shore, Auckland. Like the last, it is probably less rare than is generally supposed, as its rush-like appearance, and its growing in company with rushes, are very likely to cause it to be overlooked. It is difficult to cultivate. It also occurs in Australia.

Like the preceding one, it grows in clusters of fronds generally about one foot high, which proceed singly, yet pretty close together, from slender, scaly, shortlycreeping rhizomes. It, again, has no distinct stipes, but a branching erect stem. The lower part of this stem is of a light brown or straw colour, from one sixteenth to one eighth of an inch broad, flattened, but with projecting edges; in fact, with a a broad flat channel down the front. At about three or four inches from the ground this stem divides into two precisely like itself, and these frequently divide again. Each branch has a brush of capsule spikes, at its top, much broader than that of "S. fistulosa," but not longer. The whole plant is of a rather dull, light green, stiff, and very rough to the touch. At Wanganui, I have often found barren fronds dividing in the same way, but spreading out into a fan, and all curved over towards one side. As, however, I saw no such fronds on the Auckland plants, and find no mention of separate barren fronds in any of the authorities on ferns, I incline to think it is a local peculiarity, and only mention it to draw the attention of other collectors to the question.

SCHIZCA DICHOTOMA. (Skite-zœa di-kot-om-a.) PLATE XXIV., No. 2.

This fern belongs to the "Sub-genus Lophidium," which has the fertile segments pinnate, the fronds flattened, and capsules biserial. It is found in Cuba, Venezuela, Peru, Polynesia, Australia, the Philippines, the Malaccas, Mascaren Islands, Neilgherries, and larger forms of it in Polynesia and America. In New Zealand it only occurs in the Kauri forests, in the northern part of the North Island, and neighbouring islands. A plant said to have been gathered at Banks' Peninsula was probably "S. bifida." It is also said to occur in a bush at Rotorua. I do not know that any one has tried to cultivate this fern, which is only a few inches high. 
It has a shortly-creeping rhizome, producing numerous fronds. These spring up in the same way as those of "S. bifida," and with a similar flattened stem, but narrower. It forks almost immediately, and the branches keep dividing again and again, and spreading out like a fan. The bunches of capsule-spikes at the top are on the very ends of the branches, and form fan-like tufts instead of feather-shaped ones. Texture harsh; colour yellowish dull green.

\section{GENUS LYGODIUM (Li-go-de-um),}

Named from a Greek word "Lygodes," flexible. It has its capsules solitary (or casually in pairs) in the axils of large imbricated involucres, which form spikes, either in separate pinnæ or in lax rows along the edges of the leafy ones. There is, in New Zealand, only one fern of this genus, viz:-

\section{LYGODIUM ARTICULATUM. (Li-go-de-um ar-tik-u-la-tum.) MAORI NAMES "MANGE-MANGE," AND "MOUNGA." \\ PLATE XXII., No. 4.}

This plant, which is confined to New Zealand, is so peculiar in its appearance, that persons who had not studied the subject would hardly take it for a fern at all. Its rhizomes are long, varying in thickness, brown, shining, and wiry, without any scales, and twiring around and among the stems and branches of trees, which they ascend in this way to a height of a hundred feet or more. They are so tough that the Maoris use them for ropes, and to bind the thatch on their huts, as well as to weave into " hinakis" (basket traps to catch fish, like English eel-baskets); and so hard and stiff, where they bend round anything, that they were sharpened, after being hardened in the fire, and used as fish-hooks. The settlers have found another use for them, viz., bedding. These rhizomes constantly wind themselves into corkscrew-like coils, and the settlers fill bags with these, and make no bad representation of a spring-mattress. The stipes is variable in length, according to the character of the frond, but it and the rachides and costæ are also brown and shining. The fronds are of two characters, viz:- -barren and fertile; but it very often happens that one side of the frond is barren and the other fertile. The barren frond, or portion of a frond, is usually tri or quadripinnate, the pinnules being long, narrow, lanceolate, with entire edges, thin texture, and bright green in colour, with forked veins very conspicuous. The fertile frond, or part of a frond, is highly decompound, being sometimes divided seven or eight times, before the ultimate pinnules or capsule spikes are reached. These are arranged in clusters of from three to twelve, radiating from a common centre, are from a quarter of an inch to three eighths of an inch long, and consist of masses of spikes of dark brown or black capsules, partially enclosed in scaly involucres of the same colour. It is a difficult fern to press, as it is jointed at every forking (whence the name) and thus very liable to break somewhere or other, particularly if the specimen 
is approaching maturity, in which case the joints will part, rather than flatten or straighten out. It is, however, a very easy fern to cultivate, and will grow in almost any soil, though it will repay good soil by increased luxuriance. It should, however, have some sticks or a trellis to climb upon, in order to show it properly. It is confined to the northern portion of the North Island, not apparently extending south of the thirtyeighth parallel of latitude or thereabouts, though, as I have already stated, it is said to have been found at Rangitikei some years ago. I have also heard it called "Lygodium scandens," a name, however, that would apply to any fern of the genus, as they all climb trees in the same manner; and plants of the genus are found throughout the Tropics, and as far north as Japan.

\section{SUB-ORDER MARATTIACE ZE (Ma-rat-te-a-ce-æ)}

Is distinguished by having its capsules opening by a slit down one side, or a pore at the apex, without a ring; usually joined together, in concrete masses, in vessels called "synangia." These synangia are divided into two halves, which separate longitudinally when ripe, and each half contains several transverse cells or chambers, in which the capsules are enclosed. The whole arrangement is so different from a sorus that some botanists consider the Marratias a distinct class of plants from ferns.

\section{GENUS MARATTIA (Ma-rat-te-a),}

Named after Signor Maratti, an Italian botanist who took great interest in ferns, has its capsules sessile or stalked, and packed, four to twelve together, in boat-shaped synangia, which contain two opposite rows of capsules, and open by slits down their inner faces. The sub-genus "Eumarattia" has the synangia furnished with an obscure fimbriated inferior involucre. New Zealand has but one plant of this genus, viz :-

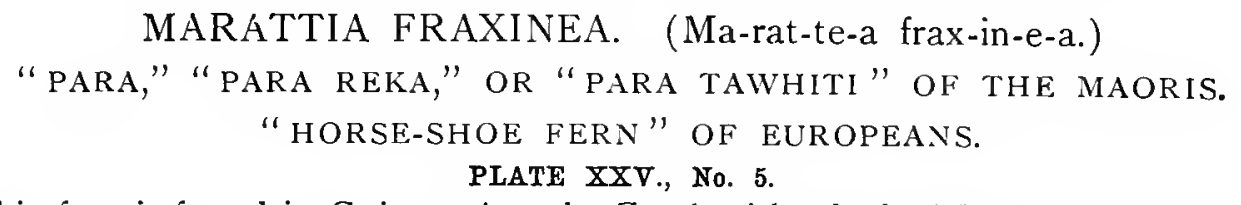

This fern is found in Guinea, Angola, Zambesi-land, the Mascaren Islands, Natal, Cape Colony, the Neilgherries, Ceylon, Philippines, Malacca, Polynesia, Queensland, and Norfolk Island, as well as in New Zealand. It was formerly plentiful in the North Island, where its tuberous roots formed an important article of food, and cause the Natives to assert that they had a potato before Captain Cook visited the Colony. The wild pigs, however, have nearly exterminated it, so that it is only now found in a few localities, extending from the North Cape to a little south of Mount Egmont. The southernmost point at which I know of its occurring in any quantity, at present, is beside the Kapoaiaia stream near Pungarehu, but thirty-five years ago it was not uncommon as far south as Waitotara, and as I have already mentioned, I know of one small patch at Rangitikei. It is also called "Marattia salicina." 
The rhizome is an irregularly-shaped tuberous mass, from which the fern may be propagated, by sub-division, in the same way as a potato. From this a crown of a few erect fronds springs, seldom more than four or six fronds to a crown. The rhizome has fleshy roots. The stipes is long, stout, brownish towards the base and green above, and both it and the rachis and costæ, which are green, are sparingly furnished, when young, with a few short, broad, brown scales, which fall off afterwards. The base of the stipes is articulated to the rhizome, and is furnished on each side with a large auricle, which curves round to meet the opposite one, and gives the whole base the shape of a horse's foot, whence the name given to the fern by settlers. The frond is bi-pinnate and broadly-ovate, sometimes almost round, but very large fronds (which are said to be sometimes fourteen feet long, stipes included), are narrower in proportion than smaller ones. The pinnæ are arranged in pairs, the topmost two forming the apex of the frond, as it is a peculiarity of the plant that there is no terminal pinna. Occasionally a frond is met with, which, at first sight, seems to have a terminal pinna, but closer examination shows it to have an abortive one alongside of it. The pinnules are narrowly oval, or sometimes bluntly pointed, shortly stalked, and also arranged in pairs with no terminal one. The pinnæ are jointed to the rachis, and the pinnules to the costæ; there being in each case an enlargement or knot covering the joint. The texture is coriaceous: colour bright glossy green, with distinct veins. The sori or synangia are situated a little within the margin, and look at first sight like small short caraway seeds. When they are ripe they open along the top, the two halves turning back, and lying side by side, with their hollow sides facing each other, and showing the cells containing the capsules. Occasionally one finds a frond with the pinnules confluent, so that each pinna is simple, with merely indented and serrated edges. The fern is only found in very wet, almost boggy, ground, and is very easily cultivated in rich soil kept well saturated with water. So long as it has these and a fair amount of warmth, shade is of little consequence; the only object, in fact, of placing the plant under the shade of trees being to protect it from frost. If insufficiently watered, the fronds at once droop at every joint, but a good watering quickly restores them. I have plants growing both out of doors and in a greenhouse, and the former look the healthiest, those in the house being very subject to black scale blight. Cattle and horses both eat this fern greedily; so it is necessary to keep it out of their reach. I know that it is grown out of doors as far south as Wellington, and I have heard that it is so at Christchurch; but as it belongs to a tropical family, it would probably need shelter farther south; in fact, I find that, even at Wanganui, and under the shade of trees, a sharp night's frost will cut the fronds, particularly the young ones. Its large size and bright glossy green at once attract notice, and make it a desirable plant for the fernery, so that all growers of ferns should try to obtain specimens for cultivation. 


\section{SUB-ORDER OPHIOGLOSSACE RE (O-fe-o-glos-sa-ce-æ)}

Has capsules deeply two-valved, opening down the side nearly to the base, without a ring. It differs from all the preceding, in having its vernation erect, that is, the fronds, instead of coming up curled like a bishop's crozier, and unrolling longitudinally, come up in the form of a spike, and unroll laterally.

\section{GENUS OPHIOGLOSSUM (O-fe-o-glos-sum),}

From "ophis" a serpent, "glossa" a tongue, has the capsules sessile, and arranged in two rows, so as to form a narrow, close spike.

\section{OPHIOGLOSSUM VULGATUM. (O-fe-o-glos-sum vul-ga-tum.) "ADDER'S-TONGUE FERN." \\ PLATE XXI., No. 6.}

This fern occurs in the Northern Hemisphere, from Lapland to Jápan and Himalayas, the Sandwich Islands, and throughout temperate North America, Abyssinia, St. Helena, Cape Colony, Mascaren Islands, and Australia, as well as in New Zealand, and Chatham Islands. It is also called "Ophioglosum costatum," and "O. elongatum," apparently in peculiar forms.

The plant has no distinct rhizome, but springs at once from fleshy roots. The stipes is long, smooth, brown or dark green, and fleshy in texture. The rachis is generally indistinct. Frond varying from broadly ovate-pointed to narrowly lanceolate, and sometimes widening gradually upwards and terminating in a rounded end. After the frond is fully developed, the fertile spike grows out of the upper side of the stipes just at the base of the frond, and looks like a prolongation of the stipes, with a long, narrow, double row of capsules at its top. The texture of the frond is softly coriaceous, with indistinct veins. The plant is very likely to escape notice, unless carefully looked for, as it usually occurs among manuka scrub, or other sheltering vegetation, and comes up in spring but dies away towards winter. The fertile spike only appears towards the end of summer, and, till then, the fern may be easily mistaken for a small dock leaf, or other similar growth. It is very easily cultivated, if carefully taken up so as not to injure the roots. It is not particular as to soil, but light, rich, sandy loam suits it best. It is best to take up a sod containing it.

\section{OPHIOGLOSSUM LUSITANICUM. (O-fe-o-glos-sum Lu-sit-an-ik-um.) "LitTle ADDER's-TONGUE." \\ PLATE XXI., No. 7.}

This little fern is found on the shores of the Mediterranean, and thence northward to Guernsey, also in the Azores, Madeira, and Guinea, and then crops up again in New Zealand. It probably occurs in the intermediate countries, but from its small size (only from two to four inches high), and its usually growing among grass, it escapes notice. It is also called "O. gramineum," and "O. minimum." It is 
distinguished from "O. vulgatum," by having from two to four barren fronds, growing out of each other's bases, before the fertile spike appears, and a tuberous rhizome; but the distinction is disputed by some authorities. The fronds are usually narrowlylanceolate, but sometimes widen gradually upwards, and have the end rounded. It is not very common, but more so than is generally supposed. To cultivate it, it is best to take up a sod containing it. The spread of hawkweed in New Zealand has made it far more difficult than before to distinguish this and $O$. vulgatum from the similarity of the weed's appearance. I fancy, too, that the hawk-weed is killing it, as it seems actually growing scarcer.

\section{GENUS BOTRYCHIUM (Bo-trik-e-um),}

So called from the Greek word "botrus" a bunch of grapes, because the bunch of capsules has a somewhat similar appearance. It has the capsules arranged, in two rows, on the faces of spikes, which form a compound panicle.

\section{BOTRYCHIUM LUNARIA. (Bo-trik-e-um lu-na-re-a.) PLATE XXI., No. 8.}

This little fern occurs in Iceland, and throughout Europe from the Arctic region to Spain and Italy. In Asia it is found from Kamschatka to the Himalayas ; in North Western America, Greenland, Newfoundland, and Canada. In the Southern Hemisphere, it has heen gathered in South Australia, Tasmania, Patagonia, and at one place in New Zealand, at the back of the Canterbury District, by Mr. J. D. Enys. He says, "On $15^{\text {th }}$ November, 1882, I was engaged laying out the line of a wire fence across a piece of ground of a peaty nature resting on a stiff clay, about 2600 feet above the sea, when I detected the first specimen of this well-known fern. After a close search I failed in finding a second; indeed, the first specimen had only just shown up. About a week later, I found a number more showing up in two spots in the same neighbourhood; a month or so later not one remained; but this may be partly owing to the dry season." This description of the locality in which the plant was found tallies exactly with the kind of places in which the fern occurs in England, where it grows from three to ten inches high; and the shortness of its duration is even less than that of the English plant, which comes up in late Spring and dies down in Autumn. I have not seen the New Zealand plant, and the figure on the Plate is, therefore, lithographed from an English specimen, which, however, agrees exactly with Professor Kirk's description of the Mount Torlesse one, at Volume XVI, page 366, of the Philosophical Transactions. He says, "The Mount Torlesse specimens do not exceed three inches in height, the roots are of a wiry character, and the base of the stem is furnished with a membranous sheath; the sterile portion of the frond is pinnate, and consists of from two to four pairs of flabellate sessile pinnules, and a deeply-cleft terminal pinnule; the fertile frond is sparingly branched, and does not exceed one inch in length; the sporangia are bright yellow in colour." $\mathrm{He}$ further adds, "A 
remarkable fact in the life-history of this species, is the great length of time which is required for the development of the frond, before it rises above the surface of the soil. On making a longitudinal section of a mature stem, the embryo frond for the ensuing year is seen to be sufficiently advanced to allow of the sterile and fertile portions being easily distinguished, the former being already coloured green at the tip; even the pinnules can be recognised, notwithstanding their rudimentary condition. Enclosed in the basal portion of this embryonic frond, we find the embryo for the second following year, and this again encloses the embryo for the third year following. The embryo for the second year is differentiated into sterile and fertile parts; but the component parts of the frond for the third year can scarcely be made out. It is only in the fourth year that the fronds appear above ground. It should be added that the embryo fronds are arranged in an alternating position, so that if the frond destined to rise above ground next year has the fertile portion directed to the right, the frond for the second following year will have the panicle directed to the left. Attention was first directed to the lengthened period required for the development of the fronds, rather more than fifty years ago, by the Mr. W. Wilson, of Warrington, the well-known bryologist."

It will be seen from the above, that this little fern is well worth searching for, in swampy, but not very wet places, during the summer months only. English experience indicates that, to cultivate the plant, it is necessary either to take up a clod of earth containing it, or to mark the spot, and transplant it when dormant in the winter. It will grow in sandy or peaty soil, but the extremes of dryness and moisture must be avoided.

BOTRYCHIUM TERNATUM. (Bo-trik-e-um ter-na-tum)

"RATTLESNAKE FERN" OF NORTH AMERICA.

PLATE XX., Nos. 5, and 5a.

This fern is found in the Northern Hemisphere, in Lapland, Siberia, Japan, Nootka, Hudson's Bay Territory southward to New Granada, Hungary, and the Pyrenees; and in the Southern one, in Australia Tasmania, and New Zealand. In the last it is pretty common, generally among the bracken or manuka scrub, and on various soils. The finest specimens I have seen were on rich sandy loam, among fern, inland of the famous Tauranga-ahika pa; some of them being fully eighteen inches high. The fern is called the "Rattlesnake fern" in North America, because its occurrence is supposed to indicate a likelihood of there being those dreaded reptiles in the vicinity. It is not supposed to harbour them, but merely to grow in situations such as they would frequent, and thus to operate as a caution to beware of snakes. It is supposed to be slightly poisonous to cattle, but I never could learn on what grounds.

This fern has no distinet rhizome, but springs at once from long fleshy roots. The stipes is erect, stout, fleshy, brown or vellow, and very variable in length. In 
sheltered situations it is long; but when growing in open ones, it is almost nominal. At the top it branches into three rachides (whence the name ternatum) each of which is bi-pinnate. The lower pinnules are stalked and the higher ones sessile, broadly ovate or lanceolate, and indented into broad rounded or pointed lobes; the general appearance of the barren frond bearing a strong resemblance to uncurled parsley. The lower portion of the stipes forms a sort of sheath, out of which the fertile spike arises and grows to a greater height than the barren frond. The upper portion of it terminates in a tri or quadri-pinnate panicle of narrow lobes, each of which bears a double row of capsules all along it. The texture of the barren frond varies greatly. In very sheltered places, where it grows large, it is almost membrarous, with distinct venation; but in open places it is very thick and fleshy, with scarcely distinguishable veins. In such cases it lies almost flat on the ground, and the fertile spike is similarly shortened, and becomes a mere dense mass of capsules not more than an inch or two in height. The colour varies from yellowish to brownish green. It is by no means unusual to find two, and occasionally three, or even four barren fronds, branching out alternately right and left, before the fertile one is reached.

There seems to be some little confusion as to the name of this plant, for though it has been variously called "Botrychium Australe," "B. Virginianum," "B. cicutarium," "B. lunarioides," and "Osmunda ternata," some of these names seem to be applied to other ferns in the Synopsis. I suspect that in this, as in other cases, the fern differs slightly in different countries and places, and thus the mere varieties are supposed to be different plants. Formerly the New Zealand plant was called "B. cicutarium," a name which exactly describes its thick, fleshy texture, when occurring in open ground, though not appropriate to the almost membranous one, which is found among high manuka scrub, yet there can be no doubt as to the two forms being identical, for when the scrub is cleared, the fern assumes the stunted fleshy type, the very same plants thus changing their character.

Variety B, "dissectum" (Plate XIII, Nos. 2 and 2a), is more local than the ordinary plant, and is always found on very rich soil and usually in light scrubby bush. It is like the other in its general character, but the barren frond is more divided, the lobes being cut quite, or nearly, down to the costæ, into narrow sharply-pointed ones. The colour is also different, varying from a dark glossy metallic green to copper colour, and the fertile spike is longer with fewer branches and capsules. It is also a smaller plant. It was formerly called "Botrychium Virginicum," and "var. B. dissectum ;" and for some time I thought it was really a distinct plant, till I found intermediate forms, connecting it with the common type.

Both varieties are easily cultivated, provided care is taken not to injure the roots in moving them, and will pay for good soil by more luxuriant growth. They require moderate shade only, and not mueh moisture to their roots. 


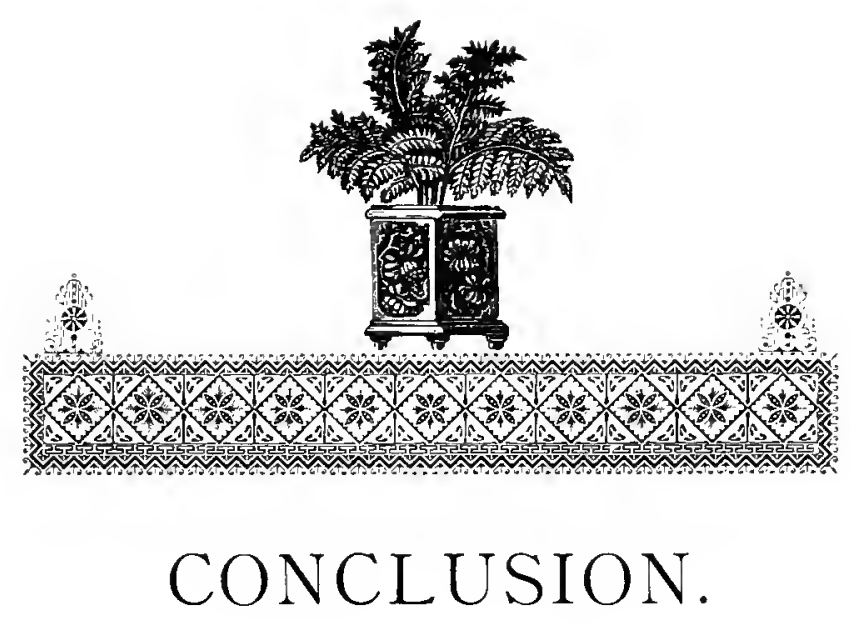

HAVE NOW FINISHED the descriptions of the ferns which, thus far, have been met with growing wild in New Zealand and its immediate dependencies; and I have mentioned those which occur in the more distant islands, which are considered as belonging to the Colony, so far as the latter class are at present known. In various places I have mentioned doubts that seem to need clearing up, as to whether ferns, generally classed separately, may not be really only forms of the same plant, changed through difference of soil and situation. Every one, who takes interest in horticulture, knows how very widely any plant may change under cultivation and at length be called by another name; and can, therefore, easily conceive that similar changes may occur under merely natural conditions. I have been often surprised at the very different appearance of ferns cultivated in different people's ferneries under one name, particularly in the case of Adianta; and, since I have grown such plants very largely myself, I have witnessed such changes in successive generations of seedlings as to satisfy me that sorts very different in appearance may be really identical. The new varieties produced, under cultivation in Europe, would almost need to be seen to be believed possible. A very remarkable instance has lately occurred within my own experience. About nine months ago, I received from Christchurch a plant of Pteris palmata, which was of the usual type, $i$ e., its fronds consisted of from three to five pairs of lateral pinnæ, and a terminal one, the whole of which were divided into long, narrow, pointed lobes, extending nearly to the costæ, so that each frond was almost bi-pinnate. I repotted it, and probably used richer soil than that in which it had been previously grown, and 
the result is that every frond, since produced, has been nearly simple, or so slightly indented in its edges, that, if plucked, it would almost certainly be taken for an ivyleaf by any one not well acquainted with the venation of ferns. While this book, too, has been passing through the press, a friend, lately arrived in the Colony, lent me a very recent work on the European ferns, from which I learned that several kinds formerly considered as distinct plants are now recognised as hybrids. I have also, through the kindness of friends, been enabled to peruse the writings of Thomé and Sachs, the great French and German botanical physiologists, which record the most recent discoveries as to the reproduction of ferns. From them I learn that since the discovery, in 1844 , that the sexual organs of Cryptogams were situated on the prothalli, the subject has been followed up, and still more wonderful discoveries have been made. It is found that pollen plays no part in the reproduction of such plants. When a pollen-grain comes in contact with an appropriate female organ, it is at once excited by the viscid moisture of the latter, and begins to grow. It sends out one or more slender filaments which penetrate the substance of the female organ till they reach the ovule or life-germ of the future fruit. They seize upon this, apparently piercing it and stirring its contents, and so causing the growth and development of the fruit. Nothing of the kind occurs in the case of cryptogams. A prothallus, or prothallium, as it is hence more generally called, usually produces several female organs, which are commonly situated on the under side of the prothallus, in, or close to, an indentation at the end farthest from the original spore and root-hairs. These female organs, which are called "Archegonia," are shaped like jars with narrow necks and no lips, and in the bottom of each there is a tiny cell, called an "ovule" or "oosphere," which is the germ of the future plant. In the case of ferns the necks are quite short, while in those of hepaticæ they are long, like Florence oil-flasks. The actual male organs, called "Antheridia," on the other hand, are situated close to, or among, the root-hairs and are generally globular or pear-shaped in form. These last, when ripe, burst and discharge minute organisms called "autherozoids" or "spermatozoids," of various forms. Thus, those of Aspidia look like tiny eels, while those of Adianta resemble two or three turns of the point of a screw, furnished with from eight to twelve tails, and those of other ferns and cryptogams assume other shapes. In all cases, however, they creep and wriggle about, till they find the mouth of a female organ, into which they enter, and so reach the oosphere within it, on which they fasten and excite it into growth. The whole process is far more analagous to what occurs in the case of animals than to that which results in the reproduction of vegetables, and this seems to indicate that, in the early ages of the world, when cryptogams originated and formed the bulk of terrestrial vegetation, the distinct lines of reproduction, which now characterise animal and vegetable life, had not been differentiated.

I see that, in the Chapter on cultivation of ferns, I omitted to note that plants, 
grown under more favourable condititons, than those in which they naturally occur, are very liable to the attacks of insects. Thus, Alpine ferns brought to low levels, and sea-side ferns carried inland, are so. Probably their texture becomes softened and more palatable to the little depredators; but the fact is unquestionable that, under the altered conditions, the plants need constant attention to prevent them from being destroyed by insect pests.

My labour of love is now ended; and in bidding farewell to my readers, I ask them to take pains to observe the peculiarities of such ferns as may come under their notice, and to join in extending a knowledge of the plants by placing their observations on record in such a form as may assist others in similar study. Short papers on such subjects, particularly if accompanied by specimens, are always welcomed as contributions by the various Philosophical Societies affiliated to the New Zealand Institute; and any which record new particulars of any importance are published in the Annual volumes of the Transactions of the Institute for the information of scientific men throughout the world. Any one who reads my book carefully will see that there are points which need clearing up; and as those who, like myself, have been engaged for many years in the study of the New Zealand flora, are getting old and so becoming daily less able to take active part in the work, it is desirable that the attention of the young should be directed to the subject. I hope, therefore, that what I have written may be the means of adding to the number of workers on botanical subjects; and I can assure them that any trouble, bestowed in this way, will bring its own reward, in no small degree, by filling the mind with wonder at the manner in which all these things have been arranged for our use and admiration.

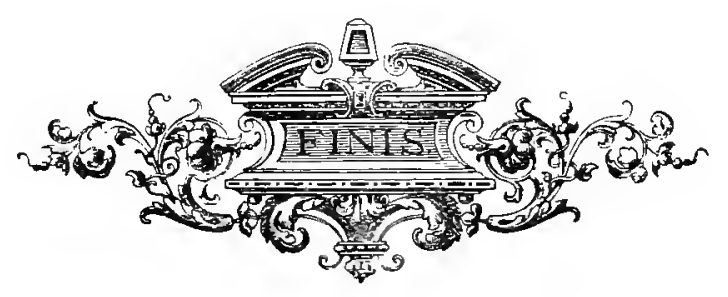




\section{N D E X.}

THE NAMES $1 \mathrm{~N}$ italics ARE SYNONYMS.

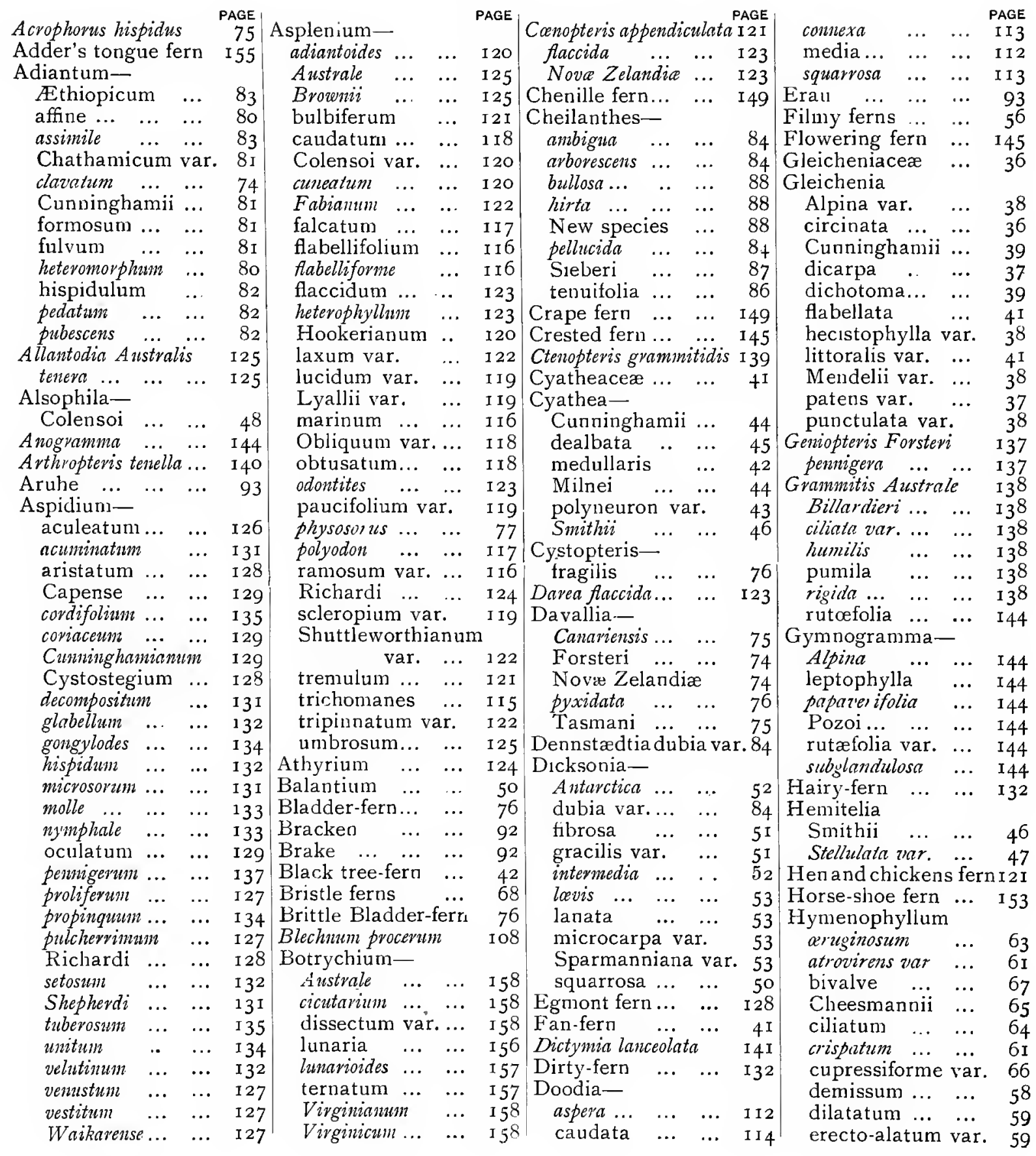




\begin{tabular}{|c|c|c|c|c|c|c|c|c|c|c|c|c|}
\hline & & PAGE & & & $\begin{array}{c}\text { PAGE } \\
\text { IO5 }\end{array}$ & & & & \multicolumn{3}{|c|}{ menbranifolium } & $\begin{array}{l}\text { PAGE } \\
\text { I } 4 \text { I }\end{array}$ \\
\hline & $\cdots$ & 63 & Capensis & $\ldots$ & 108 & velutinum ... & $\ldots$ & I 32 & molle ... & & & I 33 \\
\hline Im var & & 57 & Colensoi & $\ldots$ & 99 & Nephrolepis- & & & Novæ Zela & andi & & I 42 \\
\hline m & & $6 \mathrm{I}$ & Cumingiana & & 99 & difolia ... & $\ldots$ & I 34 & marin & & ... & I06 \\
\hline rpum va & ar. & 59 & deflexa... & ... & 99 & pectinata & $\ldots$ & 135 & $\mathrm{p}$ & & ... & I 37 \\
\hline Lyallï & $\ldots$ & $7^{\circ}$ & deltoides & $\ldots$ & 99 & tuberosa & $\ldots$ & 135 & $\mathrm{~m}$ & & $\ldots$ & I 36 \\
\hline Malingii $\quad \ldots$ & $\ldots$ & 67 & olor & $\ldots$ & IOO & Niphobolus- & & & 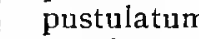 & & ... & I $4 \mathrm{I}$ \\
\hline locarpum & var. & $5^{8}$ & cata var. & ... & 108 & confluens & $\cdots$ & 140 & rugulosi & var. & c.... & I 36 \\
\hline$n \ldots$. & $\ldots$ & 66 & $\cdots$ & $\ldots$ & IO4 & glaber ... & $\ldots$ & I 4 I & ripestre & .. & ... & I 40 \\
\hline $\mathrm{m}$ & $\ldots$ & $6 I$ & ... & ... & 99 & rupestris & $\ldots$ & I 40 & scandens & ... & ... & I $4 \mathrm{I}$ \\
\hline nn1 & $\ldots$ & 66 & nis $\ldots$ & $\ldots$ & $\operatorname{Iog}$ & Nothochlæna- & & & serpens & $\ldots$ & $\ldots$ & 140 \\
\hline$m i$ & $\ldots$ & 57 & ilis ... & .. & IO9 & $\ldots$ & $\ldots$ & I 43 & setosum & $\cdots$ & ... & 132 \\
\hline $10 \mathrm{~s}$ & $\ldots$ & 58 & & 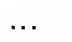 & I I I & Ophioglossaceæ & $\ldots$ & I 55 & stellatum & $\cdots$ & . & 140 \\
\hline imum & $\ldots$ & 60 & ainii var. & $\ldots$ & I06 & Ophioglossum- & & & sylvaticum & var & & 127 \\
\hline m var. & & 66 & Gilliesii & $\ldots$ & $\mathbf{1} 08$ & $u m$ & ... & I 55 & tenellum & $\cdots$ & $\cdots$ & 139 \\
\hline$\ldots$ & $\ldots$ & 57 & heterophylla & .. & 99 & atum $\quad \ldots$ & ... & I 55 & unitum & .. & ... & I36 \\
\hline rufescens ... & $\ldots$ & 63 & eolata ... & $\ldots$ & 102 & nineum ... & .. & I 55 & viscidum & ... & ... & I 36 \\
\hline sanguinolentum & $\ldots$ & 59 & linearis & $\ldots$ & Io6 & Lusitanicum & $\cdots$ & I 55 & Polystichum- & & & \\
\hline scabrum $\quad \ldots$ & $\cdots$ & 62 & oranacea & $\ldots$ & I I I & minimum $\quad \ldots$ & $\cdots$ & I 55 & aristatum & .. & $\ldots$ & I 28 \\
\hline $\mathrm{um}$ & $\ldots$ & 68 & $\ldots \quad \ldots$ & $\cdots$ & I IO & tum $\ldots$ & ... & I 55 & coriaceum & $\cdots$ & $\cdots$ & I 29 \\
\hline lissimum & $\ldots$ & 63 & folia var. & $\ldots$ & I 06 & ndaceæ & ... & I 45 & hispidum & $\ldots$ & $\cdots$ & I 32 \\
\hline lgense. & $\ldots$ & 65 & soni ... & $\ldots$ & 98 & Osmunda - & & & vestitum & $\ldots$ & $\ldots$ & 127 \\
\hline le & $\ldots$ & 66 & uga ... & $\ldots$ & IOO & lis & $\cdots$ & I 45 & onga ... & . & ... & 45 \\
\hline sum var. & $\ldots$ & 59 & $\ldots$ & ... & 99 & barbara & ... & 148 & Pteris- & & & \\
\hline Wilsoni $\quad \ldots$ & $\ldots$ & 66 & pimpinellafolia & & Iog & Capensis & ... & 108 & Alpina & & $\because$ & $9^{8}$ \\
\hline Iypolepis- & & & la var. & $\ldots$ & I06 & ... & ... & I08 & aquilina & *. & $\cdots$ & 92 \\
\hline sonioides & $\ldots$ & 84 & ata & $\ldots$ & 99 & $\cdots$ & $\cdots$ & Iog & Brunoniana & & $\cdots$ & 96 \\
\hline s. $\ldots$ & $\ldots$ & 85 & rigida ... ... & $\ldots$ & 104 & ternata & $\cdots$ & I 58 & Chilensis & & $\cdots$ & $9^{\circ}$ \\
\hline lia $\ldots$ & $\ldots$ & 85 & difolia... & $\ldots$ & $\operatorname{IOg}$ & Para & ... & I 53 & ns & $\cdots$ & $\cdots$ & 95 \\
\hline & $\ldots$ & 84 & vulcanica ... & & 99 & Para-reka .... & ... & I53 & edulis var: & $\cdots$ & $\cdots$ & 93 \\
\hline fern $\ldots$ & $\ldots$ & 68 & Lonchitis tenuifolia & $\ldots$ & 84 & Para-tawhiti... & . & I 53 & licheri: & iana & var. & 96 \\
\hline fern & $\ldots$ & 73 & $a-$ & & & Parablechnum proce & erum & 108 & lenta $v$ & var. & .. & 93 \\
\hline ern $\quad \ldots$ & ... & 145 & gghamii & ... & 55 & $10 \ldots$. & $\ldots$ & I I 8 & in & & 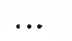 & 96 \\
\hline io $\ldots \quad \ldots$ & $\ldots$ & 99 & Lyg & & & Pellœa- & & & oides & & $\because$ & $9 I$ \\
\hline a Davallioid & & I 32 & latum & $\cdots$ & I 52 & fal & • & 88 & lia & .. & $\cdots$ & 90 \\
\hline mposita ... & $\ldots$ & I 3 I & ens $\quad \ldots$ & $\ldots$ & I 53 & difolia & ... & 89 & macilenta & .. & ... & 94 \\
\hline ella & $\ldots$ & I 32 & $\ldots$ & $\ldots$ & 42 & Phegopteris rugutose & & I 36 & micropteris & & & 96 \\
\hline hispida. & $\ldots$ & I 32 & mange & $\ldots$ & I 52 & Phymatodes- & & & montana & & $\ldots$ & 96 \\
\hline palustris. & $\ldots$ & 131 & aceæ... & $\ldots$ & I 53 & Billiardieri... & $\cdots$ & I 4 I & New speci & & .. & 97 \\
\hline thelypteris ... & $\ldots$ & I 3 I & Mar & & & tulata $\quad \ldots$ & $\ldots$ & I 4 I & erula & $\ldots$ & $\cdots$ & 94 \\
\hline velutina $\ldots$ & $\ldots$ & I 32 & sea & . & I 53 & itau, ... & $\ldots$ & 42 & tremula & & $\cdot$ & 90 \\
\hline Leptocyomium ... & $\ldots$ & 64 & salicina & & I 53 & Piu-piu ... & $\cdots$ & IOO & tilionis & & $\ldots$ & 96 \\
\hline Leptopteris- & & & Buckler-1 & ern & I30 & Platyloma- & & & Wal & & & 92 \\
\hline hymenophylloid & $\ldots$ & I 49 & raraulie & $\ldots$ & 37 & falcata... &. & 88 & Rarauhe Tar & rana & & 37 \\
\hline pelluada & $\cdots$ & I 49 & .. & & $3^{8}$ & rotundifolix & .. & 89 & Rattle-snake & fern & $n \ldots$ & 57 \\
\hline superba & 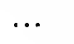 & I 49 & Moke-moke ... & $\cdots$ & I 4 & Pleopeltis pustulata. & $\cdots$ & I 4 I & $\mathrm{Ra}$ & .. & $\cdots$ & 92 \\
\hline Lindsaya - & & & Moku & & I2I & Pœes & .. & 92 & Ro & & $\cdots$ & 93 \\
\hline soni var. & $\cdots$ & 79 & wort & $\ldots$ & I 56 & odiaceæ & .. & $4 I$ & Rough tree-f & Eern & $\cdots$ & 50 \\
\hline$\because$ & $\cdots$ & 77 & Mou & $\cdots$ & I 52 & Polypodium- & & & al-fern & $\because$ & .. & 45 \\
\hline omanoides & & 78 & Nephrodium- & & & adiantiforme & & I 29 & fern & ... & ... & I I 4 \\
\hline bata var. & & 78 & positum & $\cdots$ & I3 I & uatum .. & $\cdots$ & I $4 \mathrm{I}$ & d-fern & $\ldots$ & ... & 90 \\
\hline & & 79 & um ... & & I3 I & ale.. & ... & I 38 & Schi & & & \\
\hline dder's ton & ngue & I 55 & $\mathrm{~m}$ & $\ldots$ & 132 & rdieri & & I 4 I & alis $v$ & var. & & $5^{\circ}$ \\
\hline chia comans & $s \ldots$ & 96 & ophyllum & var. & I 32 & confluens & & 140 & 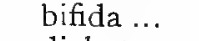 & $\ldots$ & ... & I5I \\
\hline macilenta $\quad \ldots$ & & 95 & molle ... ... & $\ldots$ & I33 & inghamii & ... & I 4 I & oma & . & $\cdots$ & I 5 I \\
\hline vtilionis & ... & 96 & ingulare & $\cdots$ & I 3 I & nutum ... & $\cdots$ & $\mathbf{I}_{3} 8$ & fistulosa & $\cdots$ & $\cdots$ & I 50 \\
\hline$a-$ & & & propinquum... & $\cdots$ & I 34 & diversifolium & ... & I 4 I & palmata & $\cdots$ & & 5 \\
\hline na & $\cdots$ & IO5 & pubescens var. & ... & I 32 & elaagnifolium & $\cdots$ & 140 & ata & $\ldots$ & ... & I 5 \\
\hline gata var. & $\cdots$ & IO3 & osun & var. & I 30 & flipes & $\ldots$ & I 39 & propinqua & ... & .. & I 5 I \\
\hline lata ... & $\ldots$ & IOI & pteris & $\ldots$ & I 30 & grammitidis & $\cdots$ & I 39 & Valdiviana & 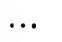 & $\cdots$ & $5 I$ \\
\hline
\end{tabular}




\begin{tabular}{|c|c|c|c|c|c|c|c|c|c|c|c|c|}
\hline Shield ferns & 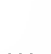 & PAGE & Stinking-fer & & 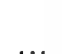 & PAGE & Trichomanes & & PAGE & rigidum & & PAGE \\
\hline Silver tree-fern & $\cdots$ & 120 & Swamn fern & M & $\cdots$ & 37 & Armstronoii & . & 60 & strictum vá & & 72 \\
\hline Slender tree-fern & $\cdots$ & $\begin{array}{l}45 \\
50\end{array}$ & Takote ... & & $\cdots$ & 51 & Colensoi .. & $\cdots$ & 71 & venosum & & 7 \\
\hline Soft tree-fern & $\ldots$ & 46 & Todea- & & & & Cunninghamii & $\cdots$ & 72 & venustulum & . & 71 \\
\hline Spicant group & $\ldots$ & IOO & Africana & $\cdots$ & . & I 48 & elongatum var. & .... & 73 & Tuakura & . & 50 \\
\hline Stegania & & & barbara & & $\cdots$ & 148 & humile & $\ldots$ & 70 & Tunbrıdge-tern & & b \\
\hline alpina & & & hymenoph & tyllo & ides & I 48 & leptophyllum & $\cdots$ & 72 & Umbrella fern & $\ldots$ & 39 \\
\hline fuviatilis & $\cdots$ & $\log$ & intermedia & a va & & 149 & Lyallii & $\ldots$ & 70 & Welri & $\cdots$ & 50 \\
\hline procera & $\ldots$ & Io8 & pellucida & $\ldots$ & $\ldots$ & 149 & Malingii & . & 67 & Welsiponga ... & & 5 \\
\hline ana hetero. & & & rivularis & & $\cdots$ & 148 & radicans & & 73 & Xiphopterishetero & hoy & 3 \\
\hline morp & & IO9 & superba & $\ldots$ & $\ldots$ & I 49 & reniforme ... & $\ldots$ & 68 & & & \\
\hline
\end{tabular}

\section{KEY TO PLATE I.}

FRUCTIFICATIONS OF N.Z. FERNS (FROM SYNOPSIS FILICUM).

I. Gleichenia. $a$, fertile pinnule of Eugleichenia. $b$, tertile pinnule of Mertensia.

2. Cyathea. $a$, fertile pinnule, one sorus open to show the capsules. $b$, sorus when empty.

3. Hemitelia. $a$, part of fertile pinnule of Amphicosmia, with one sorus empty.

4. Alsophila. $a$, fertile pinnule.

5. Dicksonia. $a$, sorus of Balantium, open and shewing capsules.

6. Loxsoma. $a$, sorus. $b$, fertile pinnule.

7. Hymenophylum. $a$, fertile pinna with open SOrus.

8. Trichomanes. $a$, sorus inserted in edge of frond. $b$, sorus exserted or stalked.

9. Davallia. $a$, fertile pinnule of Leucostegia. $b$, fertile pinnule of Eudavallia.

ro. Cystopteris. $a$, fertile pinnule. $b$, sorus and involucre.

I I. Lindsaya. $a$, fertile pinnule, showing submarginal sorus.

I2. Adintum. $a$, fertile pinnule and sori.

13. Hypolepis. $a$, fertile pinnule and sori.

14. Cheilanthes. $a$, fertile pinnule and sori.

I5. Pellea. $a$, fertile pinnule and sori.

I6. PTERIs. $a$, fertile pinnule of Eupteris. $b$, fertıle pinnule of Pœsia. $c$, fertile pinnule or lobe of Litobrochia.

17. Lomaria. $a$, fertile pinna. $b$, barren pinna.

18. Doodra. $a$, half of tertile, pinna showing sori.

19. Asplenium. $a$, fertile pinnule of Euasplenium. $b$, fertile pinnule of of Darea. $c$, fertile pinnule of Athyrium. $d$, fertile pinnule of Diplazium.

20. Aspidium. $a$, sorus and involucre. $b$, tertile pinnule of Polystichum.

21. Nephrodium. $a$, fertile pinnules of Eunephrodium. $b$, part of fertule pinnule of Lastrea.
22. Nephrolepis. $a$, fertile pinna and sori.

23. Polypodium. $a$, fertile pinnule of Phegopteris$b$, fertile pinnule of Grammitis. $c$, fertile portion of Goniopteris. $d$, fertile portion of Niphobolus. $e$, stellate hairs of Niphobolus. $f$, fertile portion of Phymatodes.

24. Nothochlæna. $a$, fertile pinnule and sori.

25. Gymnogramma. $a$, fertile pinnule and sori.

26. Osmunda. $a$, pinnule, partly barren, partly fertile.

27. Tonea. $a$, fertile pinnule of Eutodea. $b$, fertile pinnule of Leptopteris.

28. SсHızе4. $a$, fertile spike. $b$, one limb of spike with capsules.

29. Lygodium. $a$, portion of barren frond or limb. $b$, portion of fertile frond or limb.

30. Marattia. a, portion of fertile frond with synangium and fimbriated inferior involucre. $b$, synangium open, showing chambers containing the capsules.

31. Ophioglossum. $a$, portion of barren frond showing veins. $b$, portion of fertile spike with sori.

32. Botrychium. $a$, pinnule of barren fronds showing veins. $b$, portion of fertile spike with sori.

33. Capsules, \&c. a, capsules of Gleicheniaceæ. $b$, capsule of Cyatheacer, with escaping spores. $\quad c$, capsule of Loxsoma. $d$, spores very highly magnified. $e$, capsule of Trichomanes. $f$. capsule of Schizœaceæ.

34. Minor Details. $a$, section showing capsules arranged on an elevated receptacle. $b$, section showing scale and cell of Lygodium, with included capsule. 


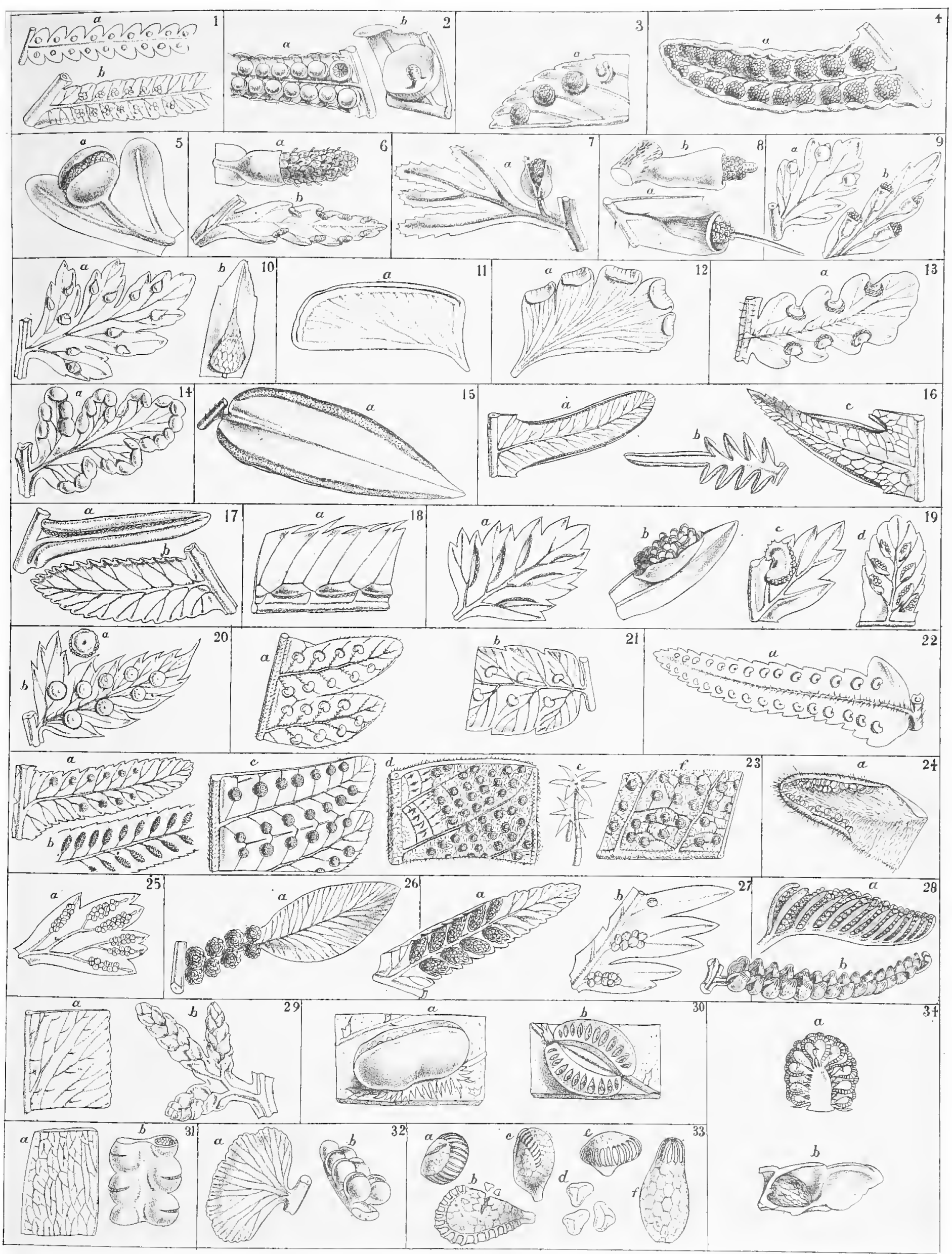

PLATE I.

FRUCTIFICATIONS OF NEW ZEALAND FERNS, MAGNIFIED. 


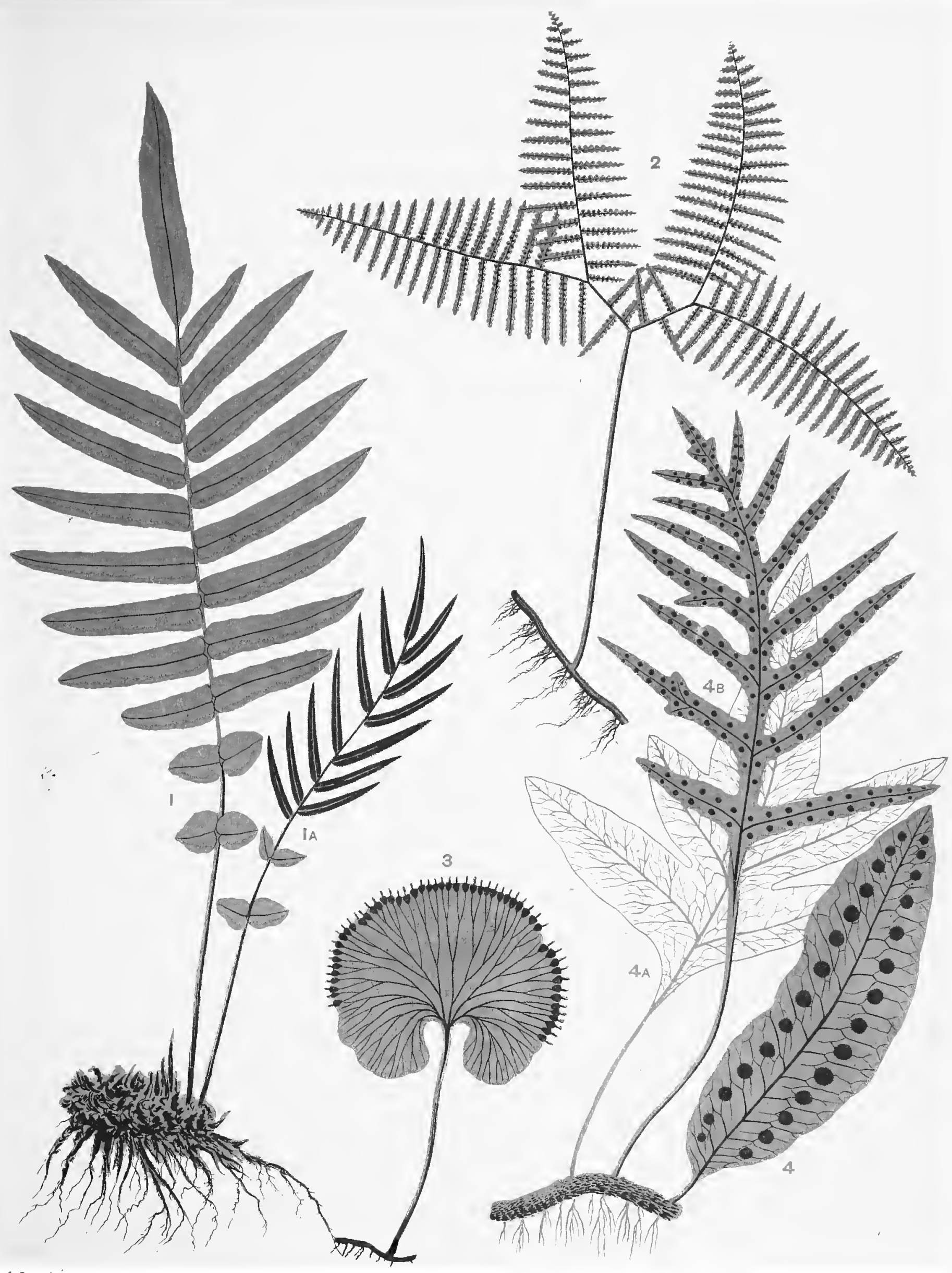



F

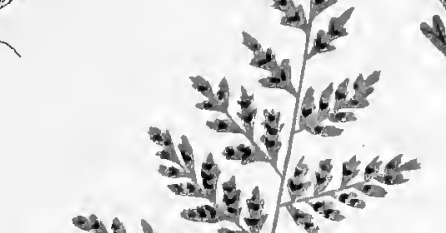

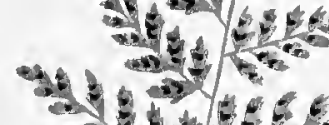

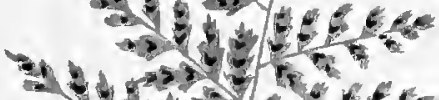
$\rightarrow y^{2}+y^{2}=6$ $3 x^{2}-b^{2}=4 k$

at $y$ y s.r. $^{2}$ An my to 业 and
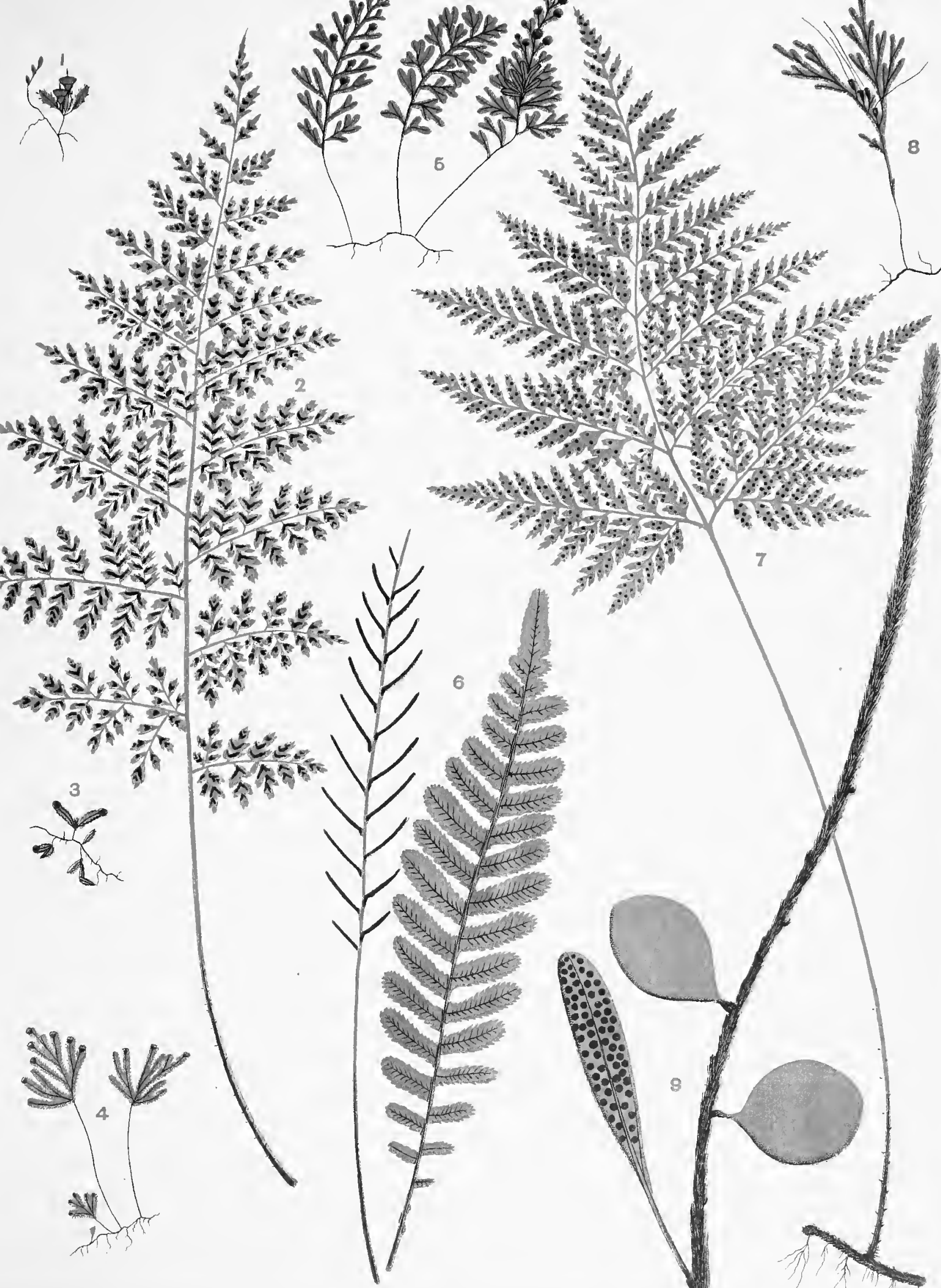

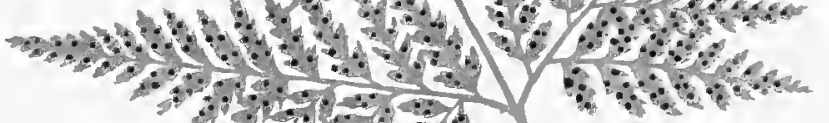

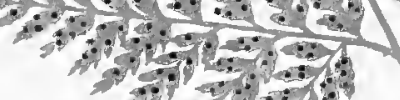




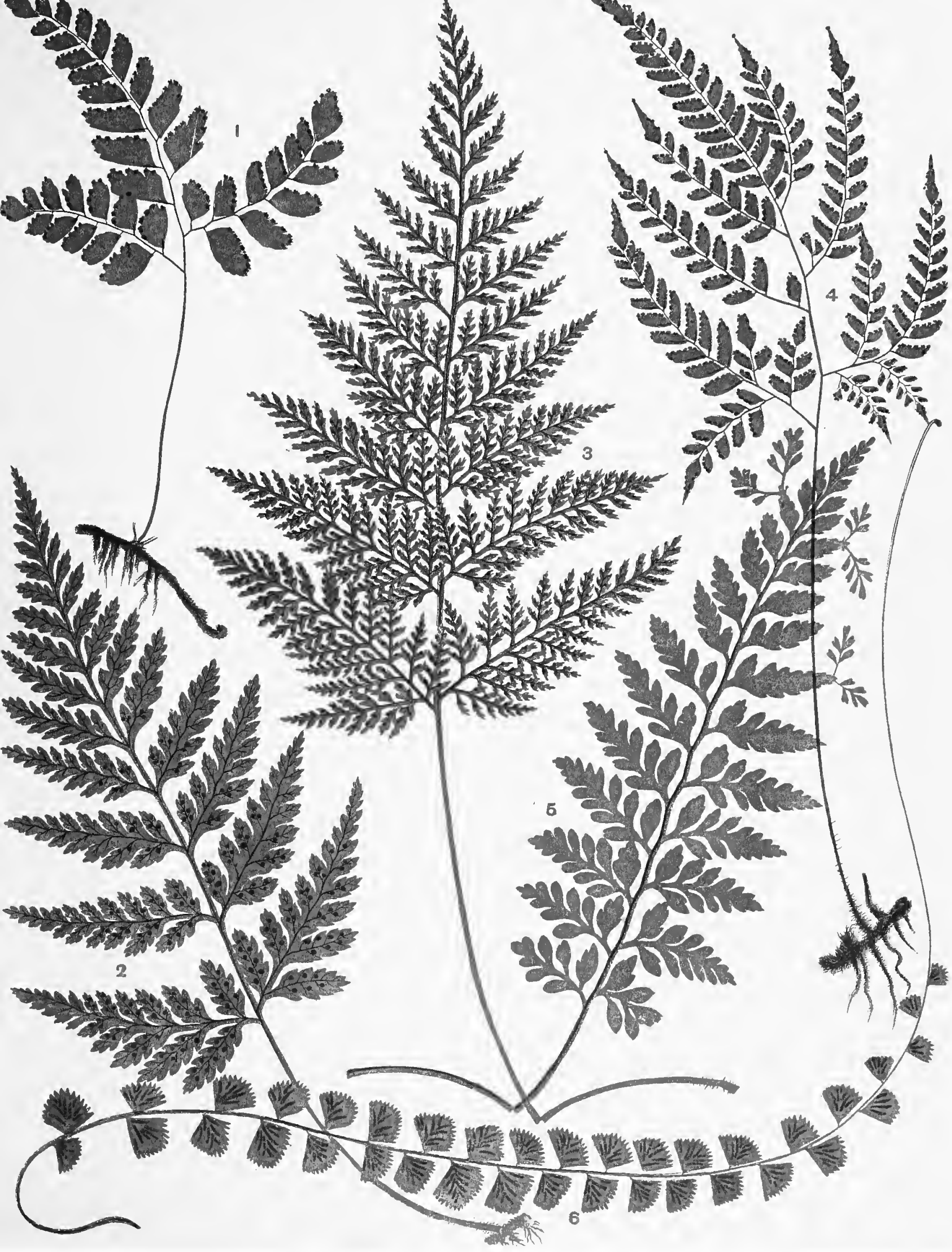

PLATE VI. 


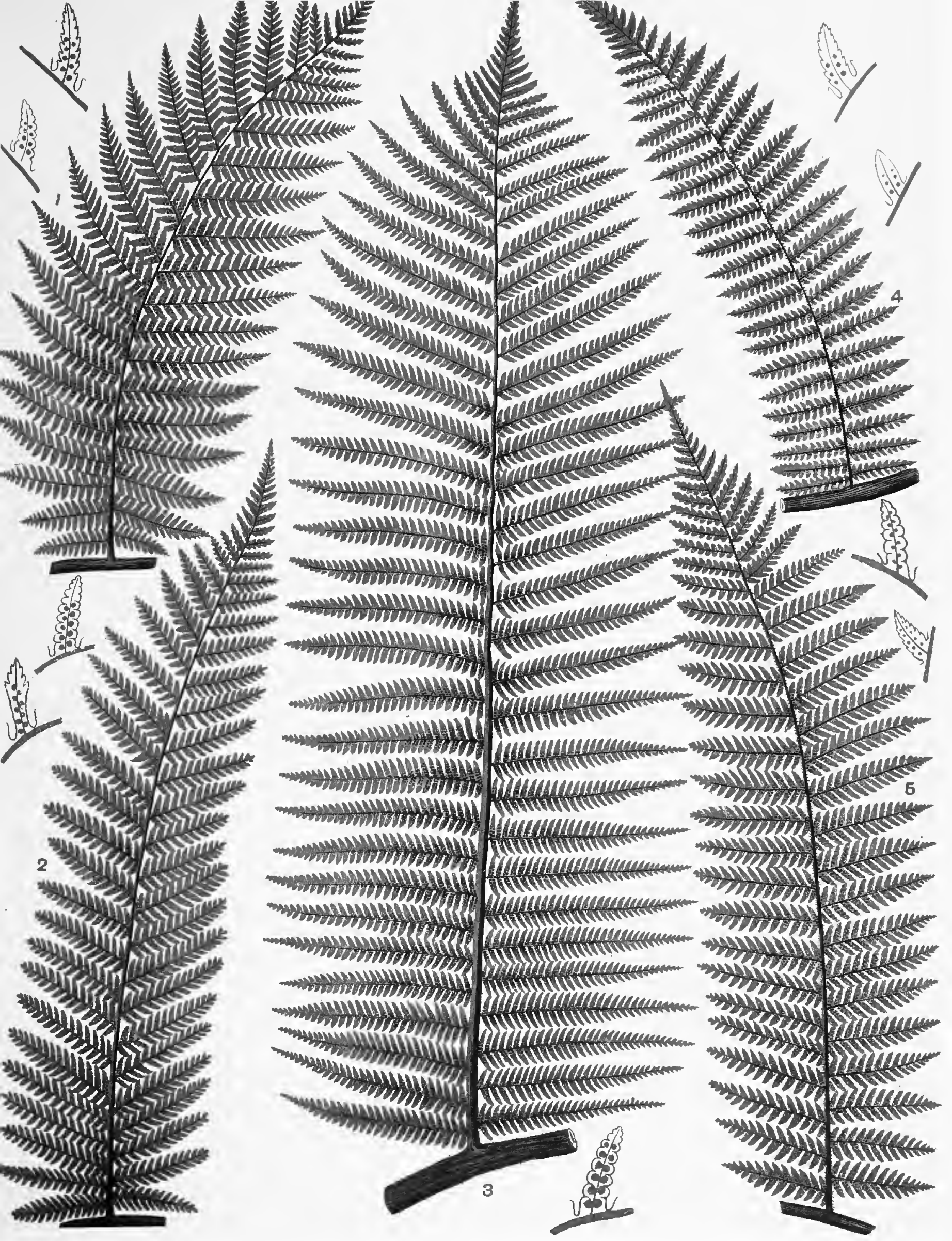




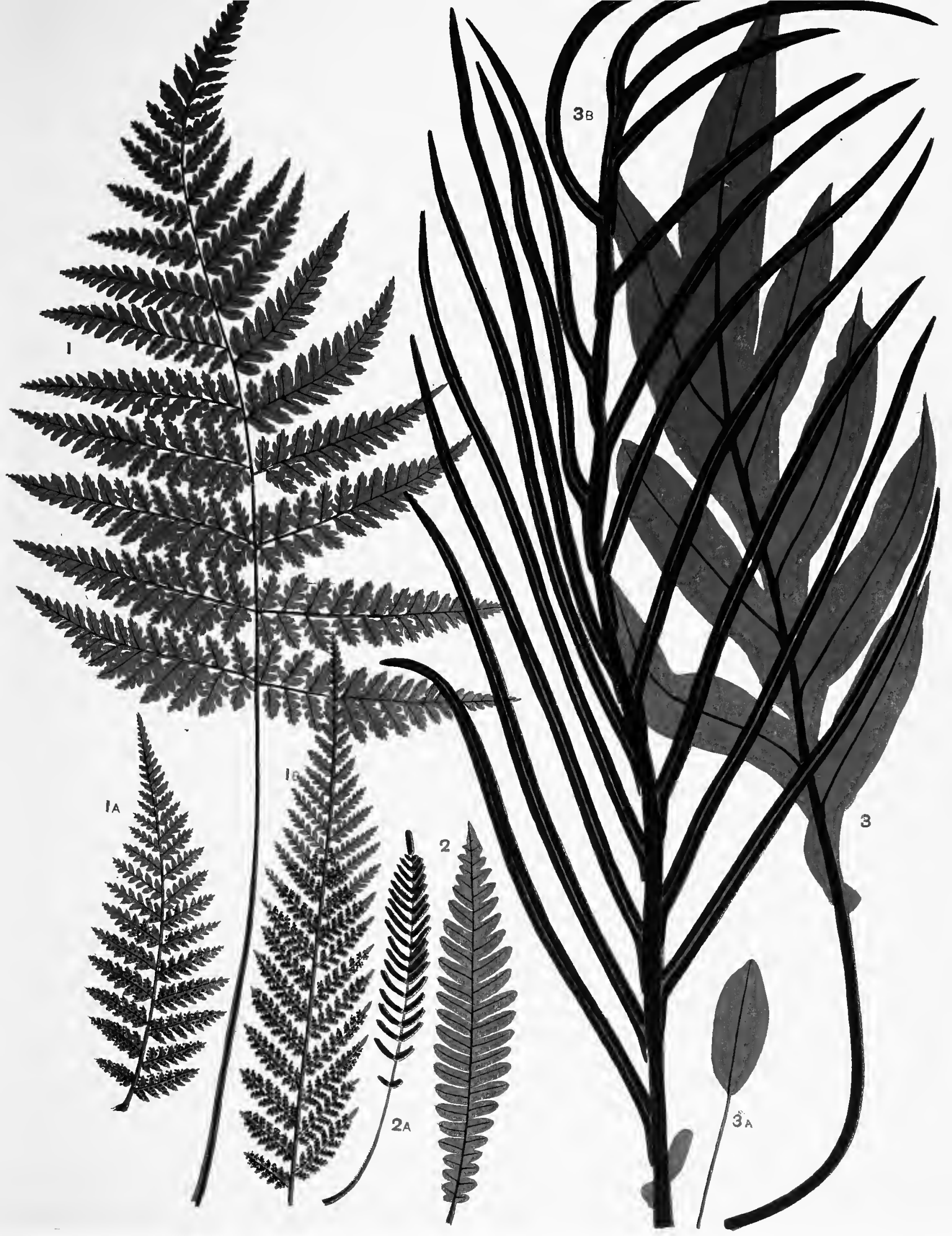

PLATE XI.

2a. Lomaria lancooleta, fertilo frond 8. do do. 8mall stmple frond 


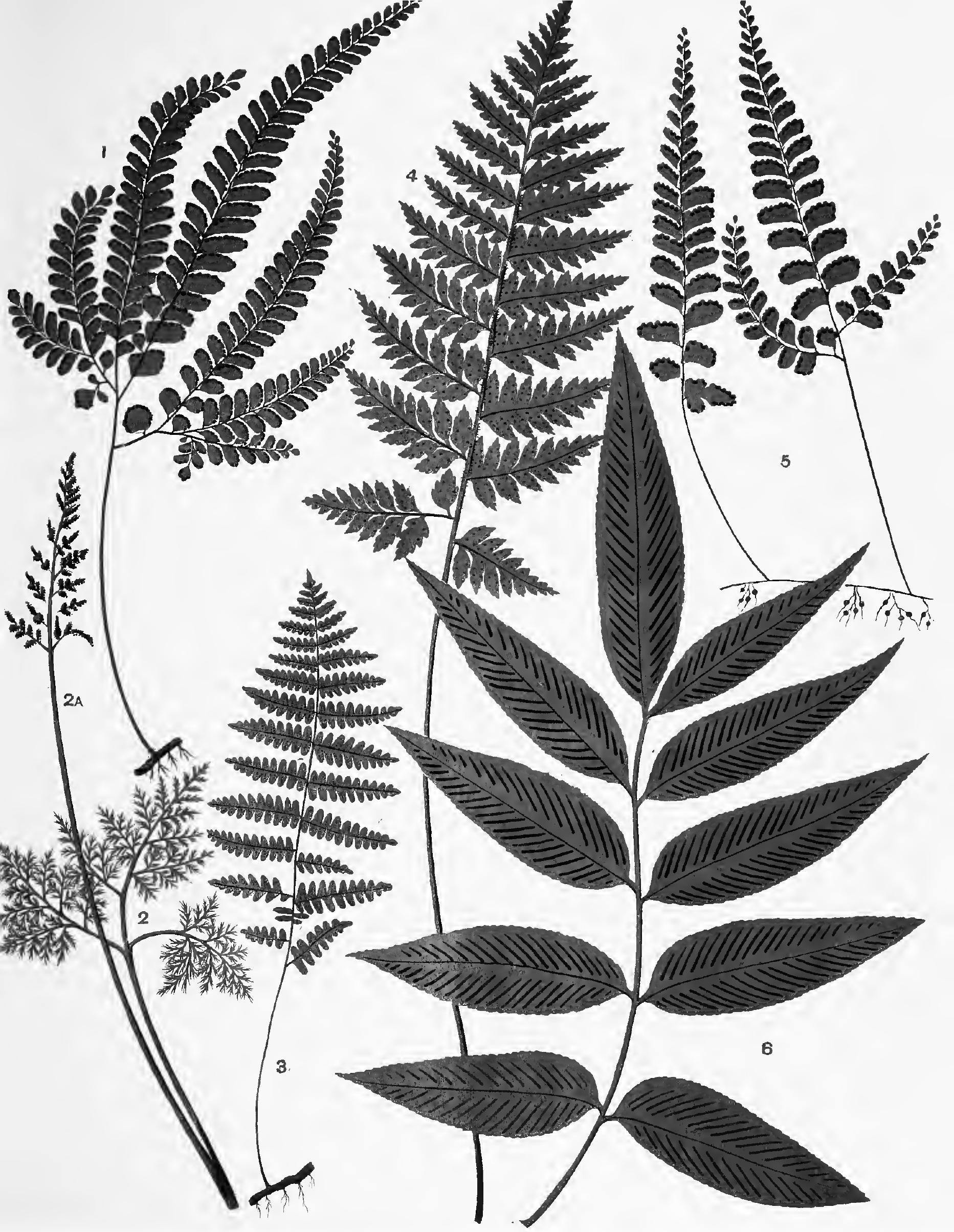




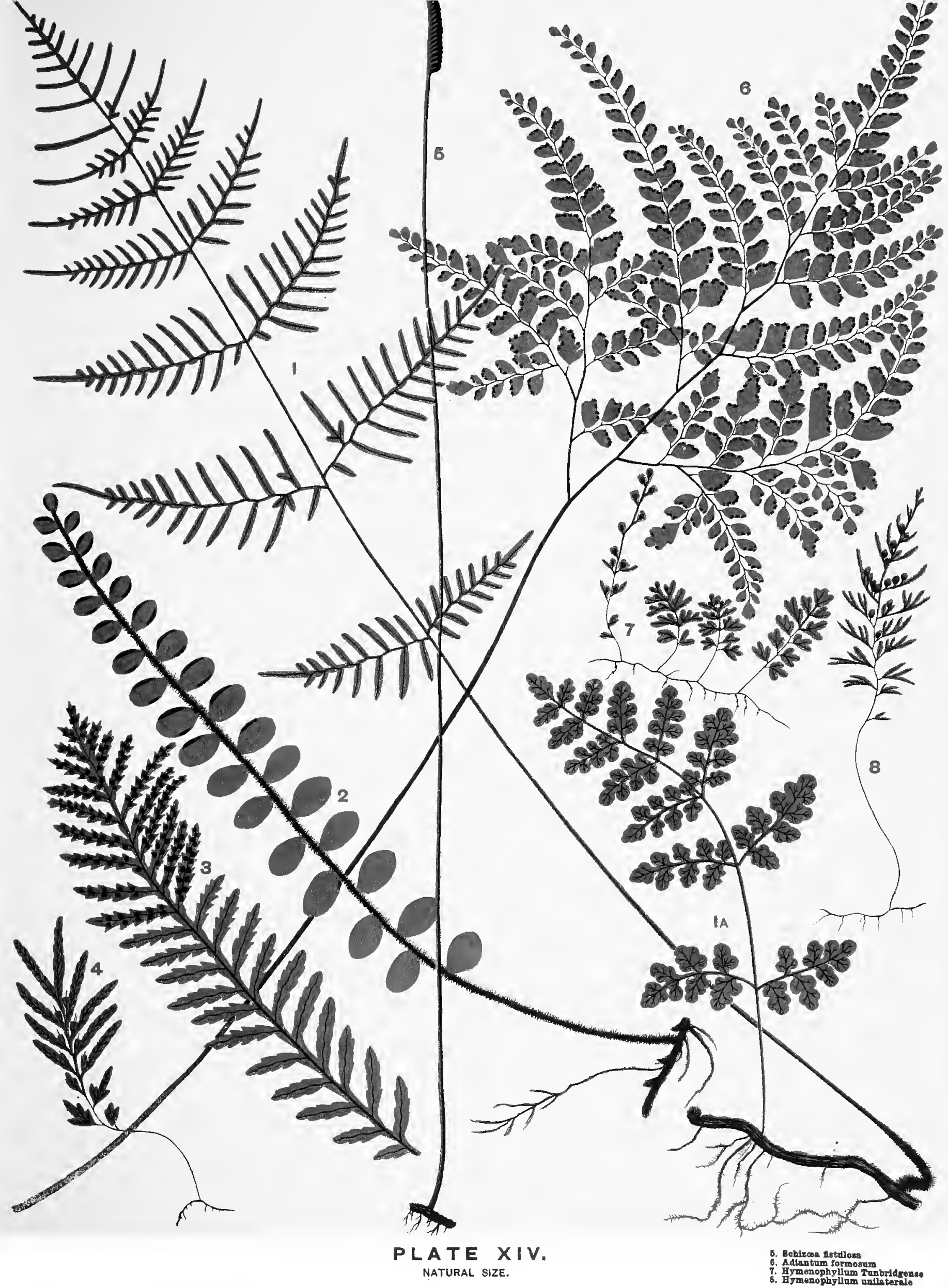



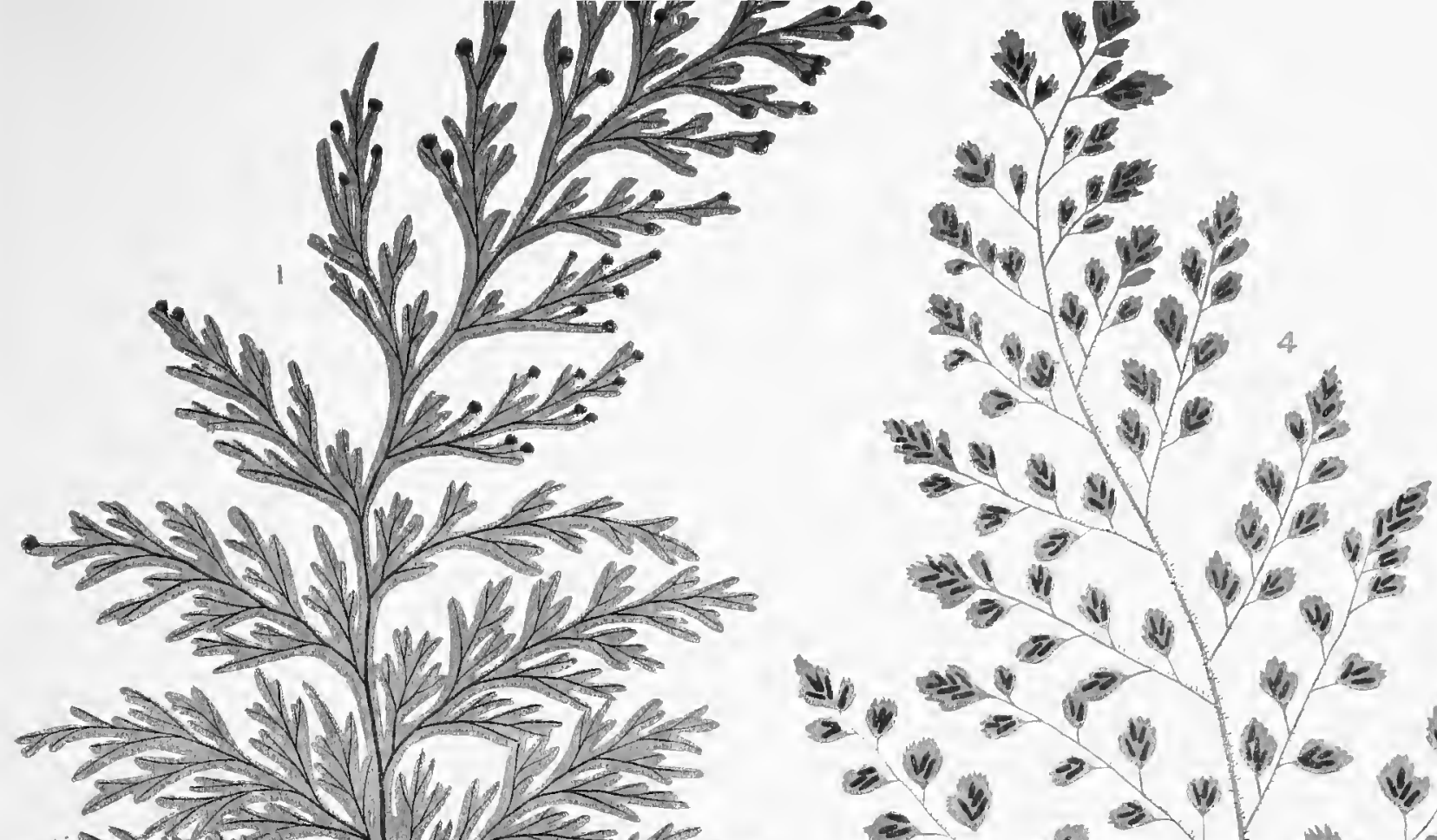

$\rightarrow 1-1+14=5$
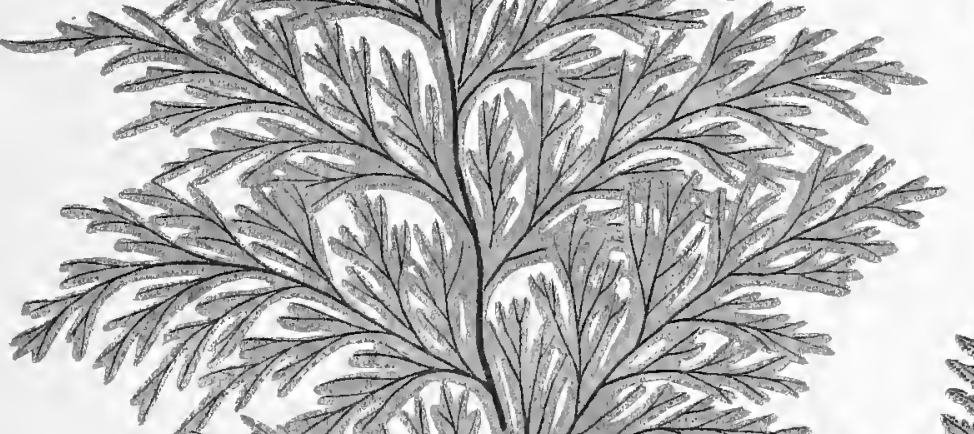

$24 y^{2}+v^{2}$ - OE

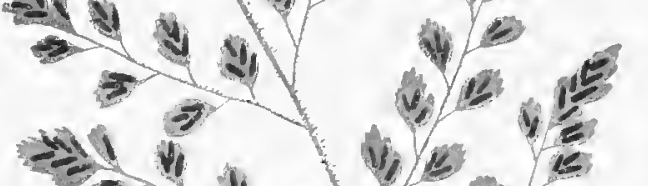

Ii 4 ,

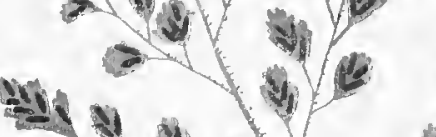

$\rightarrow v \rightarrow v+v e$

$-v \mid v$
iv $\Rightarrow \geqslant$

- $1 \geq 4$

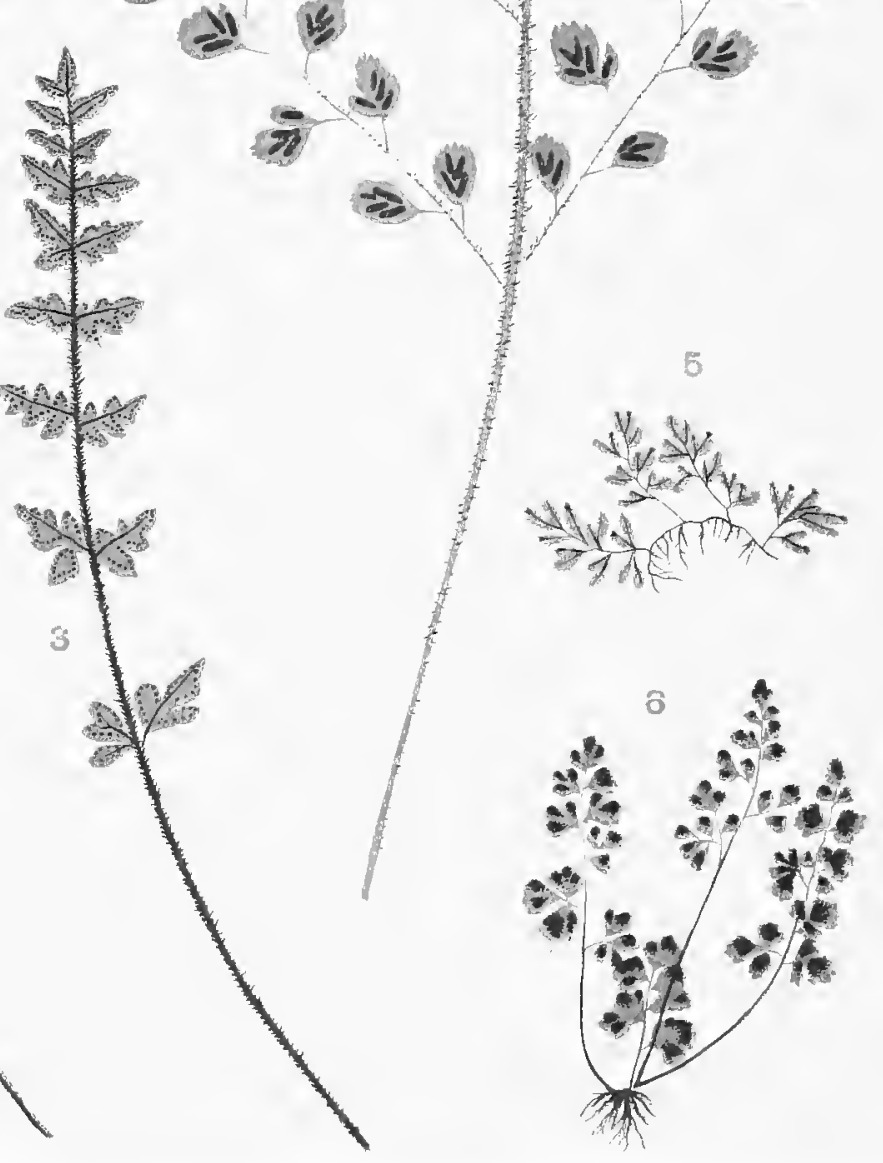




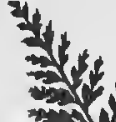

$=2(15$

netw

यद्री

n.

He

$74(1)-1)^{2}$

-

4ty ofy

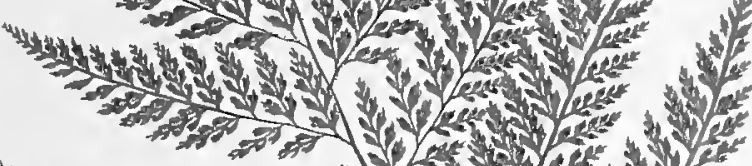

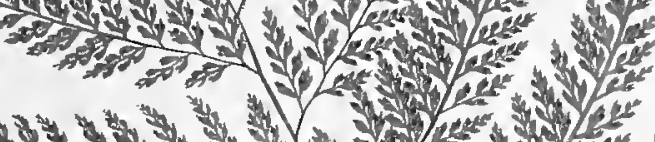

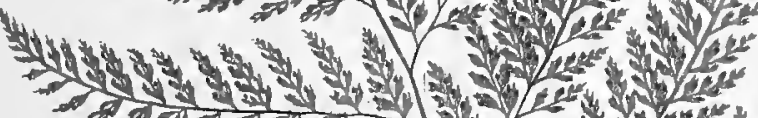

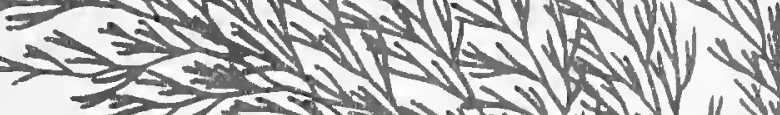

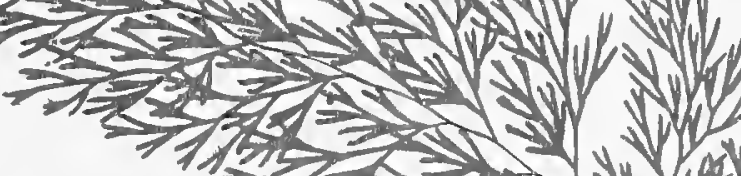

2 t.

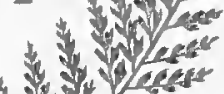

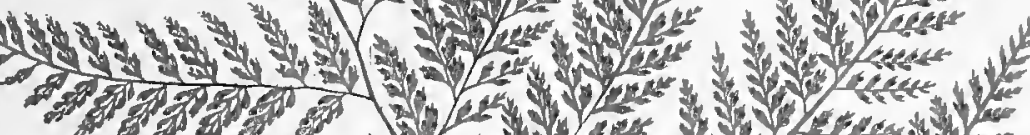

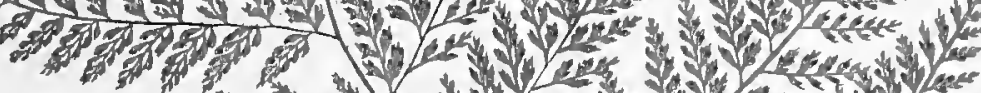

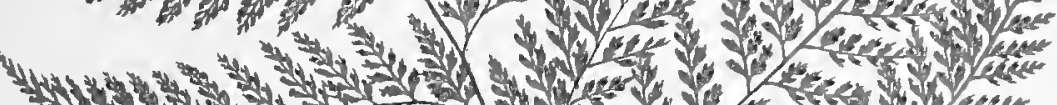

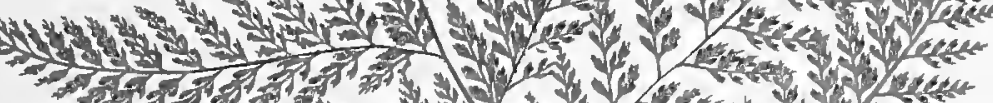

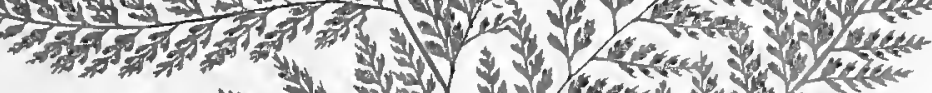

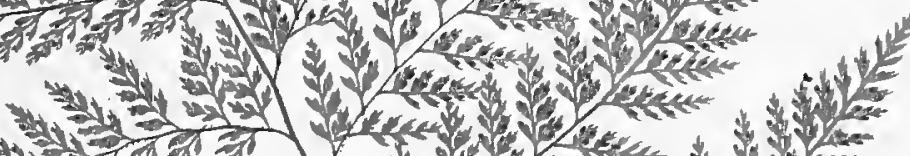

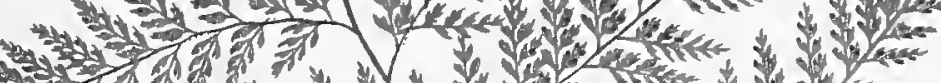

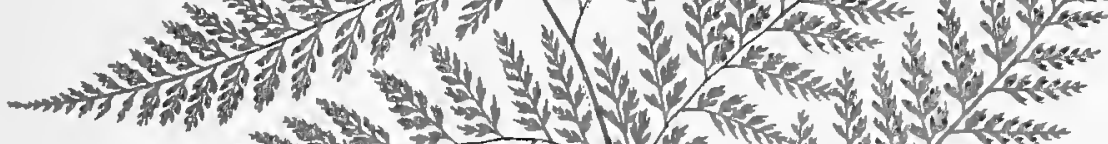
-

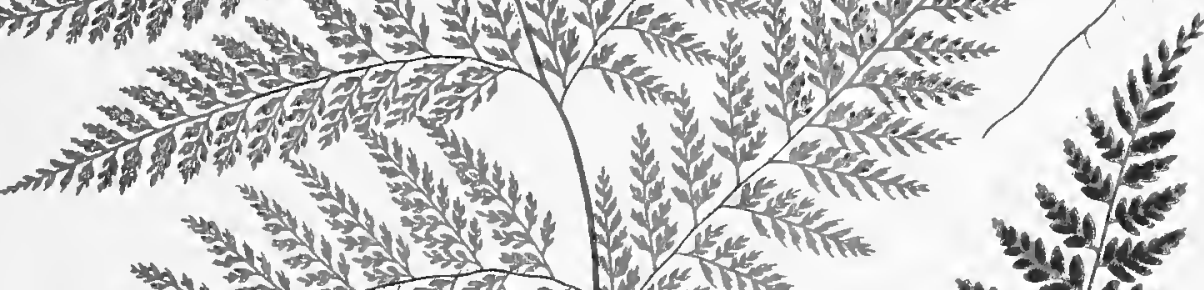

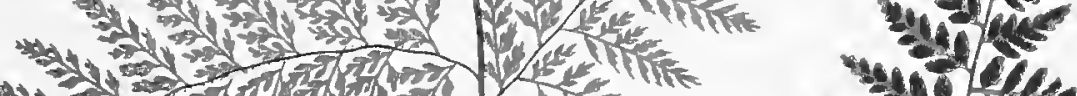

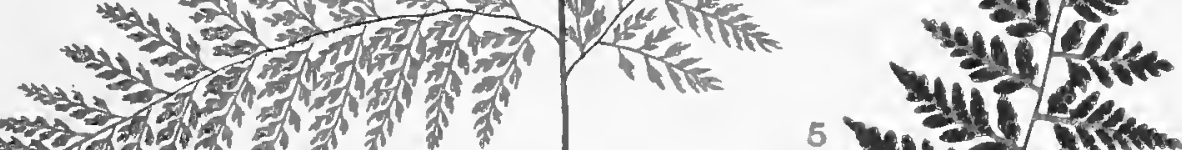

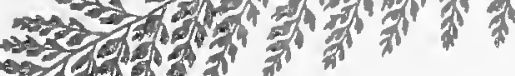
牙,

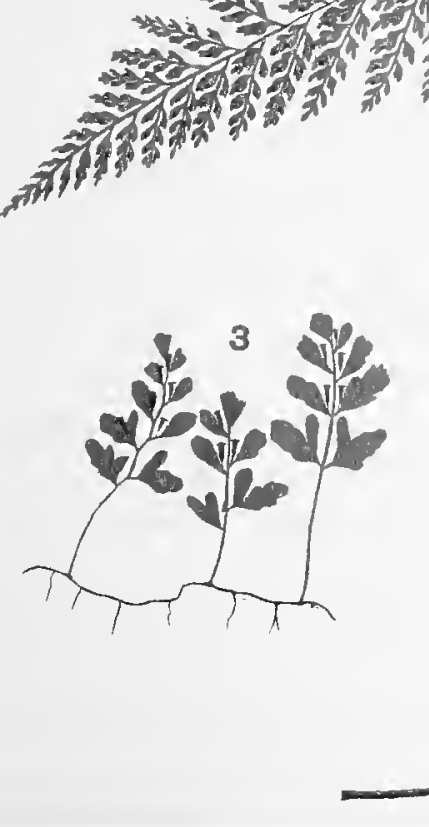





\section{等}

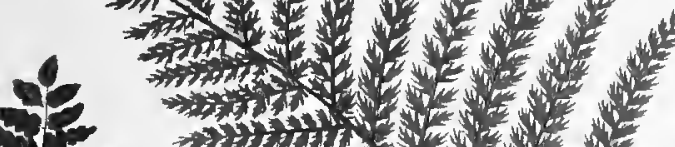

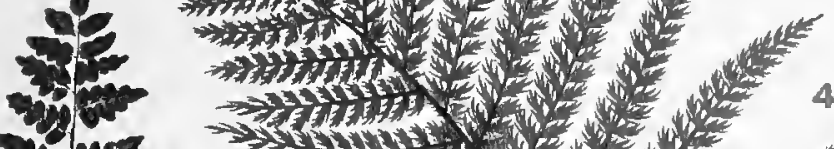

3 tis

20, $\rightarrow$ j

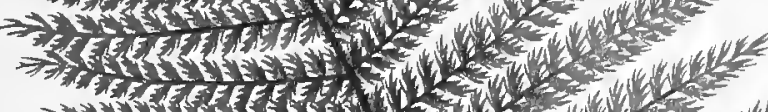

$\rightarrow+1$ H

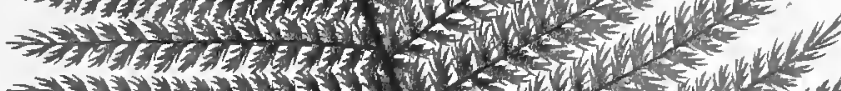

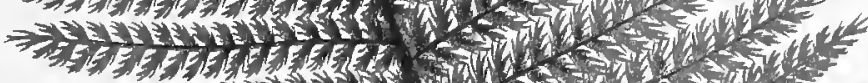

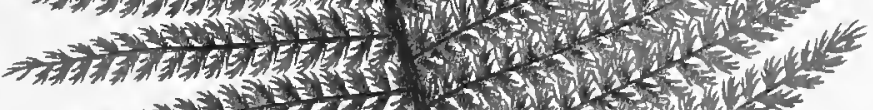

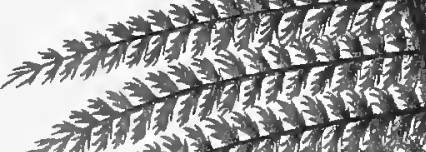

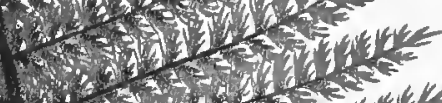

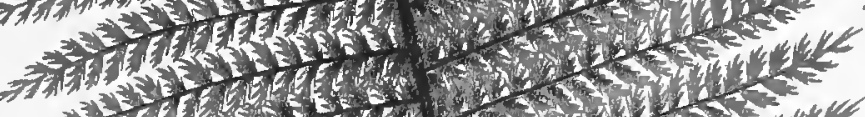

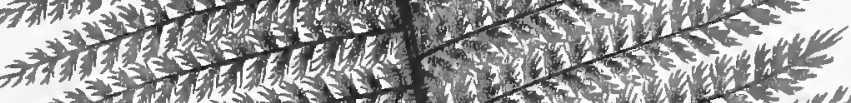

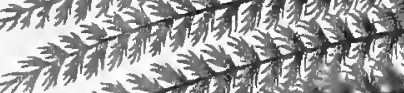

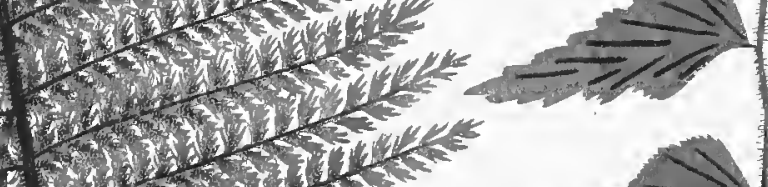

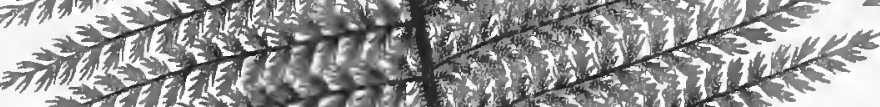

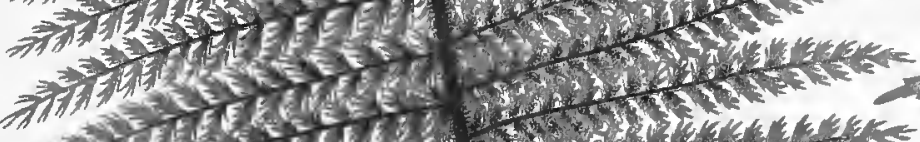
S.

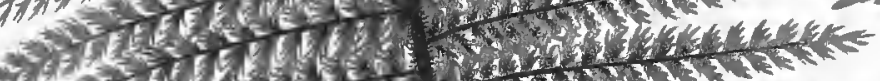
$\rightarrow$ Hol 开)

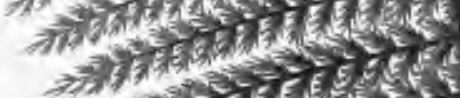
mons

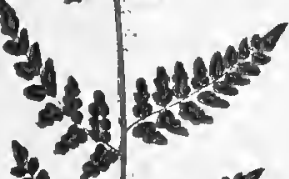

(83)

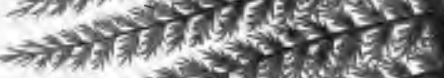

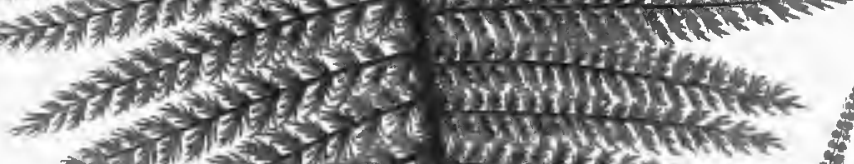
at)

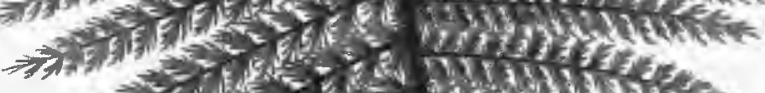

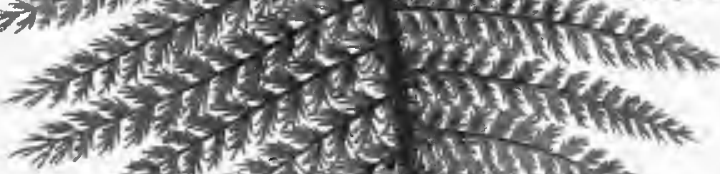
(1) 
$N$

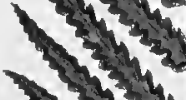

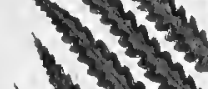

W/ $1 / 4$

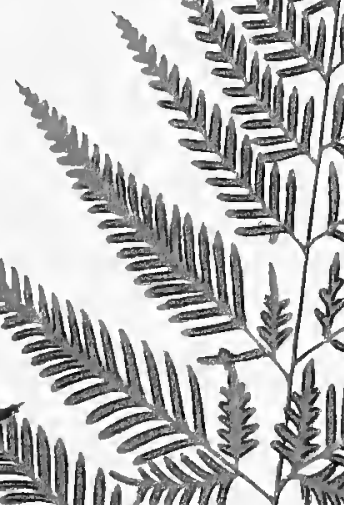

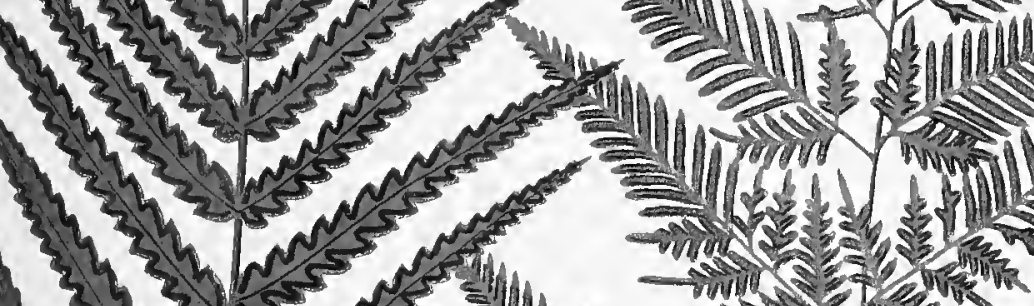

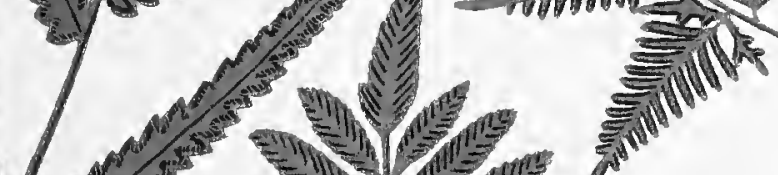
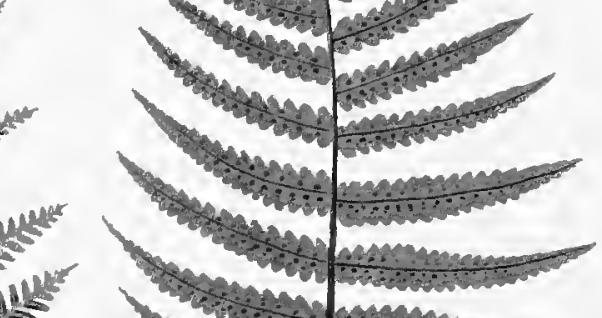


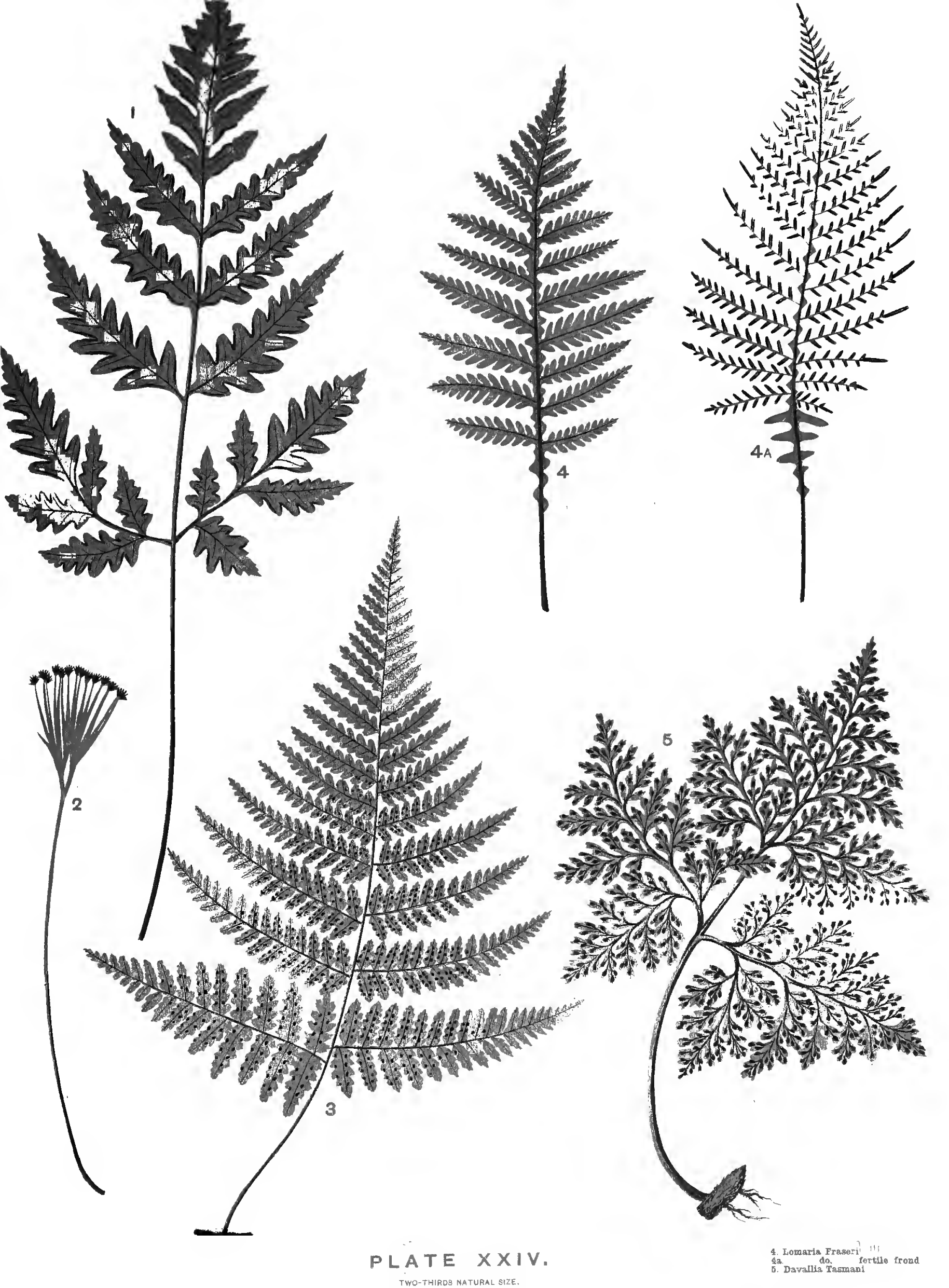





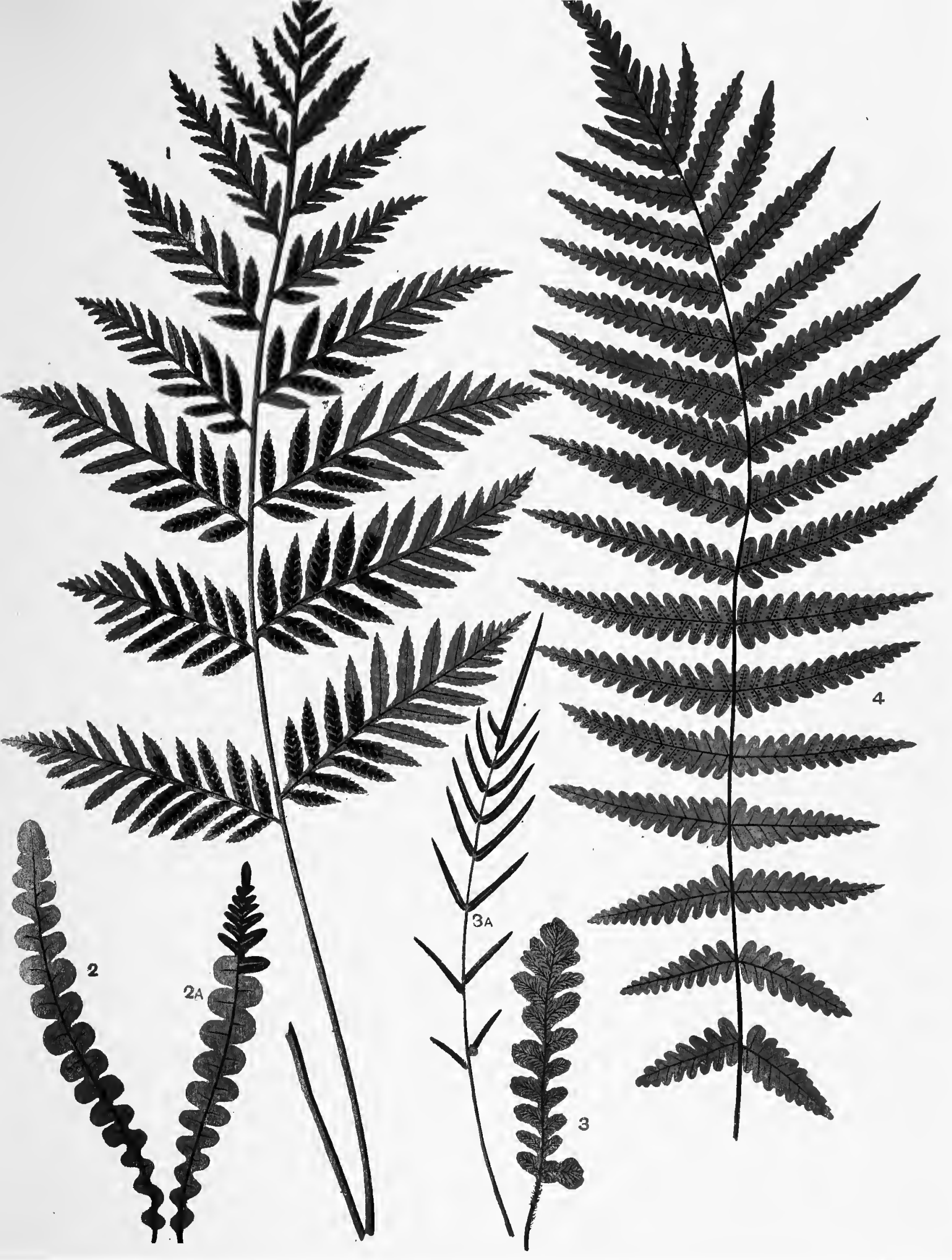




